UNIVERSIDADE DE SÃO PAULO

ESCOLA DE ENGENHARIA DE SÃO CARLOS

DEPARTAMENTO DE GEOTECNIA

\title{
EFEITO DA CONFIGURAÇÃO DAS HÉLICES NA CAPACIDADE DE CARGA À TRAÇÃO DE ESTACAS METÁLICAS HELICOIDAIS EM SOLO TROPICAL
}

\section{THIAGO DA COSTA SANTOS}

Dissertação apresentada ao Departamento de Geotecnia da Escola de Engenharia de São Carlos, da Universidade de São Paulo, para a obtenção do título de Mestre em Ciências

Área de concentração: Geotecnia

Orientadora: Prof. ${ }^{\text {a }}$ Dra. Cristina de Hollanda Cavalcanti Tsuha

São Carlos - SP 


\section{AUTORIZO A REPRODUÇÃO TOTAL OU PARCIAL DESTE TRABALHO, POR QUALQUER MEIO CONVENCIONAL OU ELETRONICO, PARA FINS DE ESTUDO E PESQUISA, DESDE QUE CITADA A FONTE.}

S237e

Santos, Thiago da Costa

Efeito da configuração das hélices na capacidade de carga à tração de estacas helicoidais em solo tropical / Thiago da Costa Santos; orientadora Cristina de Hollanda Cavalcanti Tsuha. São Carlos, 2013.

Dissertação (Mestrado) - Programa de Pós-Graduação e Área de Concentração en Geotecnia -- Escola de Engenharia de São Carlos da Universidade de São Paulo, 2013.

1. Estacas helicoidais. 2. Capacidade de carga à tração. 3. Solos tropicais. 4. Efeito da instalaçăo de estaca helicoidal. I. Título. 


\section{FOLHA DE JULGAMENTO}

Candidato: Engenheiro THIAGO DA COSTA SANTOS.

Título da dissertaçầo: "Efeito da configuração das hélices na capacidade de carga à tração de estacas metálicas helicoidais em solo tropical".

Data da defesa: 07/03/2013

Comissãu Julgadora:

Prof. Dri ${ }^{2}$. Cristina de Hollanda Cavalcanti Tsuha (Orientadora) (Escola de Engenharia de Sāo Carlos/EESC)

Prof. Titular José Carlos Angelo Cintra

(Escola de Engenharia de Sāo Carlos/EESC)

Prof. Dr. Paulo José Rocha de Albuquerque (Universidade Estadual de Campinas/UNICAMP)

Coordenador do Programa de Pós-Graduaçāo em Geotecnia:

Prof. Titular Osni José Pejon

Presidente da Comissão de Pós-Graduaçāo:

Prof. Titular Denis Vinicius Coury
Resultado:

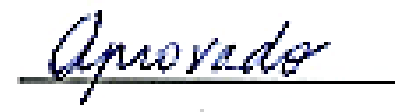

APROVADO

APNOVADO 
À Deus pela dádiva de minha vida e meu ser. À minha família, com amor, admiração e gratidão por sua compreensão, carinho, presença e incansável apoio ao longo do período de elaboração deste trabalho. 


\section{AGRADECIMENTOS}

À Prof ${ }^{a}$. Dra. Cristina, querida Cris, pela orientação, atenção, apoio, amizade, conselhos, conhecimentos adquiridos e paciência ao longo de todo esse trabalho desde sua concepção.

Aos Professores Cintra, Aoki e Tarcísio, que nos anos de convivência, muito me ensinaram, contribuindo para meu crescimento científico e intelectual.

Aos Professores Davi e Paulo da UNICAMP, pelos ensinamentos, materiais e equipamentos fornecidos que foram a base para execução dos ensaios de prova de carga.

Ao Dito, Zé e Oscar pelo apoio, ideias e soluções dadas possibilitando os ensaios.

À todos os alunos, técnicos e professores do departamento de Geotecnia da EESC, pela boa convivência, partilha e amizade que foram essenciais na vida acadêmica e pessoal.

Aos Amigos Wanessa, Rafaela, Nestor, Vinicius Peixoto, Vinicius Rocha, Tania, Gustavo Zen pela grande ajuda nos ensaios de prova de carga.

Aos parceiros de república e amigos, Irene, Madruga, Alberto, BJ, Valdeir, Txê, Piu Leandro e Marjoly, pela amizade, parceria, convivência e alegrias no meu período em São Carlos.

À meus pais, em especial ao meu Pai, Aparicio, por todo incentivo, crédito e suporte nestes anos de pesquisa.

À minha namorada, Ana Cecília, pelo amor e apoio, correções e "puxões de orelha" indispensáveis neste último ano de escrita da dissertação.

À Fundação de Amparo à Pesquisa do Estado de São Paulo (FAPESP), pela concessão de apoio financeiro para realização deste trabalho e seus ensaios.

Ao Centro de Aperfeiçoamento à Pesquisa (CAPES), pela concessão da bolsa do mestrado.

Aos Gestores do Centro Recursos Hídricos e Ecologia Aplicada (CRHEA), por colocarem à disposição a área experimental do Campus BROA na EESC/USP. 
Ao Laboratório do SET/EESC/USP, pelo ajuda na calibração das células de carga e empréstimos de materiais e equipamentos que foram vitais na execução dos ensaios.

À ASEL-TECH pelo apoio nos ensaios e facilitação na fabricação das estacas helicoidais deste trabalho. 
“A dúvida é o princípio da sabedoria.” Aristóteles 


\section{RESUMO}

SANTOS, T. C. Efeito da configuração das hélices na capacidade de carga à tração de estacas helicoidais em solo tropical. Relatório da Dissertação (Mestrado) - Escola de Engenharia de São Carlos, Universidade de São Paulo, São Carlos, 2013.

As estacas helicoidais têm sido empregadas em diversos tipos de obras no Brasil e no mundo, principalmente em casos em que a fundação é submetida a carregamentos simultâneos de tração e de compressão ou que necessitam de rápida e facilitada instalação. O maior uso nacional é em fundações de torres de linhas de transmissão de energia, no entanto, são escassos os estudos do comportamento deste tipo de estaca em solos tropicais brasileiros. Considerando-se o crescimento do uso de estacas helicoidais no Brasil, e a necessidade de um melhor entendimento do comportamento deste tipo de fundação em nossos solos, o presente trabalho foi realizado para verificar a influência do arranjo das hélices, tanto do diâmetro quanto da quantidade, na capacidade de carga à tração das estacas helicoidais multi-hélices, instaladas em solo tropical da região de São Carlos, na cidade de Itirapina próxima a lagoa do Broa. A campanha de investigações geotécnicas foi composta por sondagens de simples reconhecimento (SPT) e ensaios de cone (CPT). Foram ensaiadas nove estacas, com diferentes configurações de diâmetro e de número de hélices, instaladas com a ponta em mesma profundidade, mesmo espaçamento entre hélices (igual a três vezes o maior diâmetro) e mesmo diâmetro de haste. Nesta investigação foram medidos os torques de instalação, e realizadas provas de cargas à tração do tipo estática com carregamento rápido. Como conclusões, o atrito lateral obtido com o ensaio CPT foi útil para verificar o efeito de perda de resistência do solo com a instalação da estaca; o método de capacidades de carga individuais obteve estimativas mais próximas as medidas em prova de carga; o efeito da configuração (cônicas ou cilíndricas) influencia no torque de instalação, mas não na capacidade de carga das estacas; o acréscimo de diâmetro médio das estacas é interessante para acréscimos na capacidade de carga, no entanto o acréscimo do número de hélices, a hélice superior sempre absorve menores cargas do que a hélice da ponta da estaca.

Palavra-chave: estacas helicoidais, capacidade de carga à tração, solos tropicais. 


\begin{abstract}
SANTOS, T. C. The effect of helices configuration on the uplift capacity of helical piles in

a tropical soil. Report of Dissertation (master's degree) - Escola de Engenharia de São Carlos, Universidade de São Paulo, São Carlos, 2013.
\end{abstract}

The helical piles have been used in different types of constructions, especially in cases where the foundation is subjected to tension and compression loads. In Brazil, this type of pile is normally used as the foundation of towers of power transmission lines, as guyed masts and self-supporting towers. However, there are few studies about the behavior of helical piles in Brazilian tropical soils. Considering the growing use of helical piles in Brazil, and the need of a better understanding of the behavior of this type of foundation in our soils, this study was conducted to evaluate the influence of the arrangement of the helices on the uplift capacity of helical piles installed in the tropical soil of São Carlos zone of São Paulo State. For this study, geotechnical investigations were carried out: standard penetration tests (SPT) and cone tests (CPT). Nine piles with different configurations (diameter and number of blades) were tested after being installed with the tip at the same final depth into the ground, and the same relative helix spacing (S/D>3). For this investigation, the torque necessary to install the piles were recorded, and subsequently static tensile loads tests were performed on all piles. As results: the lateral friction obtained with the CPT test was useful to check the effect of losing soil strength with the installation of the screw pile, the individual bearing method obtained estimates closer measurements in load test then cylindrical shear method; the effect of configuration (conical or cylindrical) influences on the torque installation, but not the uplift capacity of the screw piles, increases in the size of average diameter of helix in screw piles make increases in uplift capacity, however the increase in the number of helix did not appear as good as increases in the average diameter of the helix..

Keywords: helical piles, uplift capacity, tropical soils. 


\section{LISTA DE FIGURAS}

Figura 1.1: Torre de transmissão de linhas de energia

Figura 1.2: Estaca metálica helicoidal utilizada como ancoragem de dutos em (a) imagem e (b) foto (ASEL-TECH, 2010).

Figura 1.3: Casos de (a) estacas curtas devido a camadas pouco espessas de solos e (b) estacas longas devido a camadas espessas de solo pouco resistentes.

Figura 1.4: Histograma da razão entre capacidade de carga real e capacidade de carga prevista pelo método da ruptura do cilindro $\mathrm{Q}_{\text {med }} / \mathrm{Q}_{\text {cal }}$ (HOYT e CLEMENCE, 1989).

Figura 1.5: Histograma da razão entre capacidade de carga real e capacidade de carga prevista pelo método das capacidades individuais $\mathrm{Q}_{\text {med }} / \mathrm{Q}_{\mathrm{cal}}(\mathrm{HOYT} \mathrm{e}$ CLEMENCE, 1989)

Figura 1.6: Histograma da razão entre capacidade de carga real e capacidade de carga prevista pelo método empírico $\mathrm{Q}_{\text {med }} / \mathrm{Q}_{\mathrm{cal}}(\mathrm{HOYT}$ e CLEMENCE, 1989)........ 26

Figura 2.1: Farol com fundação em estaca helicoidal (CHANCE CO., 1994)....................... 30

Figura 2.2: Estacas metálicas helicoidais simples e multi-hélices (KULHAWY, 1985). ....... 31

Figura 2.3: Foto de estacas metálicas helicoidais (Carvalho, 2007).................................... 31

Figura 2.4: Estaca metálica helicoidal e seus elementos constituintes. (CARVALHO,

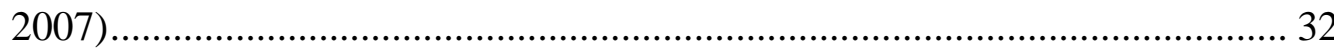

Figura 2.5: Esforços de tração e compressão da estacas helicoidais de torres sob ação de vento.

Figura 2.6: Imagens da (a) conexão parafusada utilizada na ancoragem helicoidal e (a) do torquímetro. (Tsuha, 2007).....

Figura 2.7: Instalação da estaca através de retro escavadeira com torquímetro adaptado. Tsuha (2007).

Figura 2.8: Mecanismo de ruptura (a) do cilindro e (b) capacidades de carga individuais (HOYT e CLEMENCE, 1989).

Figura 2.9: Superfície de ruptura idealizada por Mitsch e Clemence (1985) em areias para condição de fundação profunda (DAS, 1990)

Figura 2.10: Coeficientes de empuxo à tração na carga última $\left(\mathrm{K}_{\mathrm{U}}\right)$ para fundações em estacas helicoidais solicitadas à tração (Mitsch e Clemence, 1985) 
Figura 2.11: Fator de capacidade de carga à tração (Nqu) versus razão H/D para estacas helicoidais em areia (MITSCH E CLEMENCE, 1985).

Figura 2.12: Fator de Capacidade de Carga versus ângulo de atrito do solo (DAS et al 1976)

Figura 2.13: Relação entre ângulo de atrito interno e fator de capacidade de carga à tração (modificado de CHANCE, 2003).

Figura 2.14: Modelos das estacas multi-hélices: (a) Cilíndricas e (b) Cônicas. .48

Figura 2.15: Curvas Tensão x Deslocamento das Provas de Carga realizadas represa de Eaton (CLEMENCE et al., 1994).

Figura 2.16: Módulo de Rigidez Normal Inicial x Número de Hélices das Estacas (modificado de CLEMENCE et al., 1994). .50

Figura 2.17: Eficiência de uma estaca cilíndrica de três hélices em função do espaçamento relativo entre hélices (S/D). (LUTENEGGER, 2011).

Figura 2.18: Eficiência das estacas helicoidais cilíndricas em função do número de hélices e de S/D constante. (LUTENEGGER, 2011).

Figura 2.19: Ensaio de Prova de Carga rápida à tração em Contagem, Minas Gerais (Modificado de TSUHA, 2007).

Figura 3.1: Entrada do Campus do Centro de Recursos Hídricos e Ecologia Aplicada (CRHEA) - Entrada Setor 1

Figura 3.2: Mapa de localização do Centro de Recursos Hídricos e Ecologia Aplicada (Fonte: CRHEA LOCALIZAÇÃO, 2011)...

Figura 3.3: Área escolhida para os experimentos da dissertação 60

Figura 3.4: Locação da área de sondagem e estacas dentro do CRHEA (desenho fora de escala / medidas em metros).

Figura 3.5: Terraplanagem do local de ensaios

Figura 3.6: Curva granulométrica do solo do campo experimental na profundidade de $9 \mathrm{~m}$.

Figura 3.7: Imagem do terreno com as estacas instaladas, estacas no centro do círculo vermelho.

Figura 3.8: Esquema geral em planta de todos os ensaios realizados no campo experimental, medidas em metros.

Figura 3.9: Ensaio de umidade gravimétrica das amostras do SPT. .65

Figura 3.10: Ensaio CPT - Investigação do subsolo máquina PAGANI. 66 
Figura 3.11: Imagens (a) da tentativa de realização do CPT acima da área projeção das hélices e (b) do "gap" gerado entre a haste e o solo.

Figura 3.12 Ilustração do ensaio CPT próximos as estacas.

Figura 3.13: Ensaio CPT (a) próximo as estacas e (b) detalhe ampliado da haste da estaca e do cone do CPT.

Figura 3.14: Modelos das estacas ensaiadas nesta pesquisa.

Figura 3.15: Identificação das estacas ensaiadas (diâmetros das hélices em centímetros)...... 70

Figura 3.16: Distribuição esquemática em planta da locação das estacas metálicas helicoidais no campo experimental, medidas em metros. 70

Figura 3.17: Retirada do braço da retroescavadeira e colocação do mandril hidráulico 71

Figura 3.18: Imagens de (a) marcação de pontos de leitura a cada meio metro e (b) leitura do medidor de pressão diferencial

Figura 3.19: Equipamentos fornecidos para a instalação: (a) Cabeçote de aço de ligação estaca-mandril, (b) Medidor de pressão diferencial e (c) Mandril Hidráulico.

Figura 3.20: Equipamentos utilizados na prova de carga: (a) aquisição da célula de carga, (b) célula de carga, (c) cilindro hidráulico vazado, (d) relógio comparador,

(e) bomba hidráulica.

Figura 3.21: Ilustração da fachada do sistema de reação, medidas em metros. 75

Figura 3.22: Ilustração da vista do sistema de reação, medidas em metros. 75

Figura 3.23: Fogueira de madeira utilizada como sistema de reação 76

Figura 3.24: Peça de Acoplamento (a) instalada no campo e (b) isolada. 77

Figura 3.25: Visão frontal da prova de carga à tração, mesma vista da ilustração da Figura 3.21 78

Figura 3.26: Visão do esquema de prova de carga com fogueira e vigas de referencia 78

Figura 3.27: Visão da lateral (transversal) do sistema de reação da prova de carga a tração, mesma vista da ilustração da Figura 3.22.

Figura 3.28: Imagens do (a) sistema de aplicação de carga e (b) dos quadro relógios comparadores nas duas vigas de referência.

Figura 3.29: Ensaio de prova de carga a tração totalmente montado, realizado nesta pesquisa.

Figura 4.1: Gráfico do teor de umidade vs profundidade baseado a amostragem dos ensaios SPT 
Figura 4.2: Gráfico dos resultado índice SPT.

Figura 4.3: Perfil Interpretado do solo com base nos 3 ensaios SPT.

Figura 4.4: Gráficos com os resultados dos 3 ensaios CPT (resistência de ponta, qc; resistência lateral, fs; razão de atrito, Rs) e a interpretação do Perfil de acordo com Robertson et al. (1986).

Figura 4.5: Gráfico com a indicação em vermelho de todas as camadas resultantes do ensaio CPT.

Figura 4.6: Resumo com gráficos comparativos dos resultados de CPT e SPT.

Figura 4.7: Medições de torque de todas as estacas ao longo da profundidade de instalação.

Figura 4.8: Gráficos do torque de instalação para estacas do modelo A - (hélices de mesmo diâmetro igual a $20 \mathrm{~cm}$.

Figura 4.9: Gráficos do torque de instalação para estacas do modelo B (diâmetros das hélices são crescentes.

Figura 4.10: Gráficos do torque de instalação para estacas do modelo C (diâmetros das hélices são crescentes).

Figura 4.11: Gráficos de comparação entre estaca sem hélice e estaca com uma hélice. 97

Figura 4.12: Gráficos de comparação entre estaca sem hélice e estaca com duas hélices. ......98

Figura 4.13: Gráficos de comparação entre estaca sem hélice e estaca com três hélices.

Figura 4.14: Gráficos de comparação entre os torques registrados apenas na camada em que as hélices foram instaladas.

Figura 4.15: Gráfico das curvas Carga vs Deslocamento vertical de todas as provas de carga a tração.

Figura 4.16: Gráfico das curvas Carga vs Deslocamento vertical dos ensaios nas estacas do Modelo A (hélices iguais de 200mm).

Figura 4.17: Gráfico das curvas Carga vs Deslocamento vertical dos ensaios nas estacas do Modelo B (crescentes entre $150 \mathrm{~mm}$ e $250 \mathrm{~mm}$ ).

Figura 4.18: Gráfico das curvas Carga vs Deslocamento vertical dos ensaios nas estacas do Modelo C (crescentes entre 200mm e 300mm)

Figura 4.19: Gráfico das curvas Carga vs Deslocamento vertical dos ensaios nas estacas com apenas 1 hélice (B1 com 150mm e A1 com 200mm).

Figura 4.20: Gráfico das curvas Carga vs Deslocamento vertical dos ensaios nas estacas com apenas 2 hélices $(\mathrm{B} 2$ com Dmédio $=175 \mathrm{~mm}$, A2 com Dmédio $=$ $200 \mathrm{~mm}$ e C2 com Dmédio $=225 \mathrm{~mm})$. 
Figura 4.21: Gráfico das curvas Carga vs Deslocamento vertical dos ensaios nas estacas com apenas 3 hélices $(\mathrm{B} 3 \mathrm{com}$ Dmédio $=200 \mathrm{~mm}$, A3 com Dmédio $=$ $200 \mathrm{~mm}$ e C3 com Dmédio = 250mm).

Figura 5.1: Gráfico com os valores registrados de torque na aplicação e remoção da estaca B1, no furo teste.

Figura 5.2: Gráfico da relação Torque e SPT médio para todos as estacas.

Figura 5.3: Resistencia de ponta (qc) de todos os ensaios CPT (executados próximos e distantes das estacas).

Figura 5.4: Comparação entre os valores de fs próximos as estacas do Modelo e a média entre dos valores de fs dos ensaios CPT 1, 2 e 3.

Figura 5.5: Comparação entre os valores de fs próximos as estacas do Modelo B e C e a média entre os valores de fs dos ensaios CPT 1, 2 e3.

Figura 5.6: Efeito de instalação da estaca metálica helicoidal cilíndrica (hélices de igual diâmetro).

Figura 5.7: Hipótese de perturbação do solo após a instalação de estaca helicoidal cônica (com hélices crescentes).

Figura 5.8: Comparação das curvas de torque de instalação versus profundidade entre as estacas A3 e B3.

Figura 5.9: Parcelas de torque mobilizadas durante a instalação da estaca helicoidal (Tsuha e Aoki, 2010).

Figura 5.10: Gráficos com as parcelas de torque (em percentagem) resistida por cada hélice das estacas A3 (cilíndrica), B3 e C3 (cônicas) durante a instalação.... 127

Figura 5.11: Comparação entre as curvas carga-deslocamento vertical das estacas A3 e B3.

Figura 5.12: Perturbação do solo tropical com a instalação da estaca e seu efeito na capacidade de carga a tração da mesma.

Figura 5.13: Parcelas de torque de instalação correspondentes a cada hélice das estacas A3, B3 e C3.

Figura 5.14: Ilustração do solo perturbado durante a instalação das hélices, e do cilindro de solo solicitado durante o carregamento à tração das estacas.

Figura 5.15: (a) Modificado de Ensaios de Clemence et al. (1994) e (b) Ensaios nas Estacas A1, A2 e A3.

Figura 5.16: Gráfico de comparação das curvas Carga vs Deslocamento vertical das estacas A2 e B2 (B2 com 175mm, A2 com 200mm).

Figura 5.17: Toques de instalação em profundidade das estacas A2 e B2 
Figura 5.18: Gráfico do efeito do diâmetro médio na capacidade de carga das estacas. ....... 141

Figura 5.19: Calibração do Mandril de aplicação da carga .................................................. 155

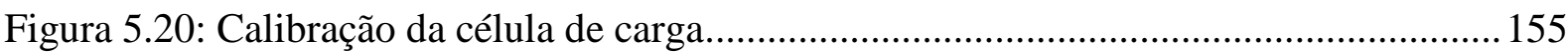




\section{LISTA DE TABELAS}

Tabela 2.1: Valores de $\mathrm{Ku}$ versus ângulos de atrito de solo $\varphi$ para estacas helicoidais profundas (Mitsch e Clemence, 1985)

Tabela 2.2: Valores recomendados de $\mathrm{K}_{\mathrm{T}}$ em função do diâmetro do fuste da estaca (HOYT e CLEMENCE, 1989).

Tabela 2.3: Valores recomendados de $\mathrm{K}_{\mathrm{T}}$ em função do diâmetro do fuste da estaca (PERKO, 2009).

Tabela 2.4: Resultados das capacidades de carga de estacas cônicas e cilíndrica de três hélices de mesmo diâmetro médio. (Modificado de LUTENEGGER, 2011)

Tabela 2.5: Parcelas de capacidade de carga à tração relativas às hélices das estacas com três hélices ensaiadas em centrífuga (dimensões convertidas para o protótipo). TSUHA et al (2007)

Tabela 2.6: Critérios normalmente utilizados para interpretação das curvas carga e deslocamento em estacas helicoidais (modificado de ZHANG ET AL, 2005 APUD LIVNEH E NAGGAR, 2008)

Tabela 3.1: Distribuições percentuais dos diâmetros médios das partículas obtidos com o ensaio granulométrico

Tabela 3.2: Dimensões das estacas, medidas em milímetros.

Tabela 4.1: Valores do Teor de umidade gravimétrica ao longo da profundidade baseado na amostragem do ensaio SPT.

Tabela 4.2: Valores do índice de penetração $\mathrm{N}_{\mathrm{SPT}}$ vs profundidade de ensaio

Tabela 4.3: Interpretação dos Resultados de CPT para classificação dos perfis de solo.

Tabela 4.4: Relatório dos furos CPT com distância do eixo de cada furo ao eixa da estaca em questão

Tabela 4.5: Comprimentos da haste da estaca helicoidal acima do nível do terreno, valores em $\mathrm{cm}$

Tabela 4.6: Torque final de instalação das estacas helicoidais.

Tabela 4.7: Quadro resumo dos resultados capacidade de carga à tração $(\mathrm{Qu})$, de todas as estacas ensaiadas.

Tabela 5.1: Tabela de resultados das razões entre Torque de instalação e o N SPT1, 2 e 3. 
Tabela 5.2: Valores estimados e medidos da capacidade de carga à tração das estacas ensaiadas

Tabela 5.3: Valores medidos (prova de carga) e previstos das parcelas de contribuição das hélices superiores das estacas ensaiadas (estacas com duas ou três hélices)

Tabela 5.4: Percentagem de redução dos parâmetros do solo obtidos através de retroanálise pelo método das capacidades de carga individuais.

Tabela 5.5: Valores das parcelas de torque de instalação correspondentes a cada hélice para cada um dos modelos das estacas ensaiadas.

Tabela 5.6: Valores das porcentagens do torque de instalação correspondentes a cada hélice para cada um dos modelos das estacas ensaiadas

Tabela 5.7: Resultados da capacidade de carga das estacas ensaiadas e as parcelas de contribuição de cada hélice.

Tabela 5.8: Quadro resumo da influência do acréscimo do diâmetro médio das hélices da estaca $\Delta$ Dmed no acréscimo de capacidade de carga à tração $\Delta \mathrm{Qu}$

Tabela 5.9: Quadro comparativo entre os resultados de $\mathrm{K}_{\mathrm{T}}$ medidos e os sugeridos pela literatura.

Tabela 5.10: Pressões diferenciais registradas durante a instalação, medidas a cada meio metro. 


\section{SUMÁRIO}

CAPITULO 1 - INTRODUÇÃO ............................................................................... 21

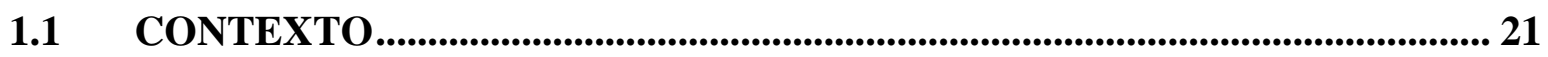

1.2 RELEVÂNCIA DA PESQUISA ....................................................................... 22

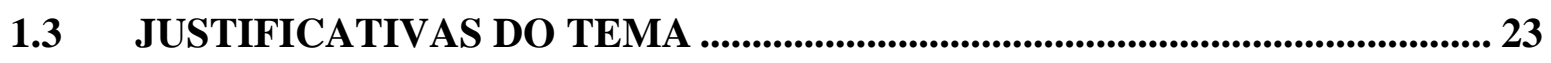

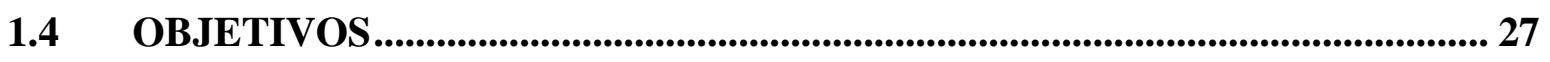

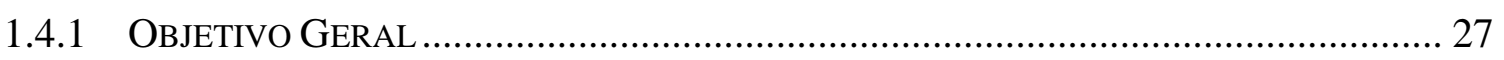

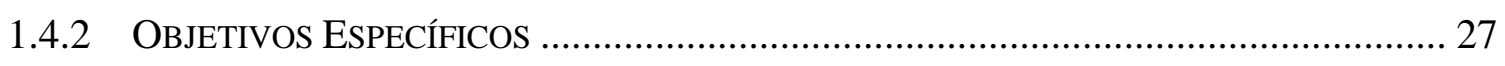

CAPITULO 2 - REVISÃO BIBLIOGRÁFICA.................................................................... 29

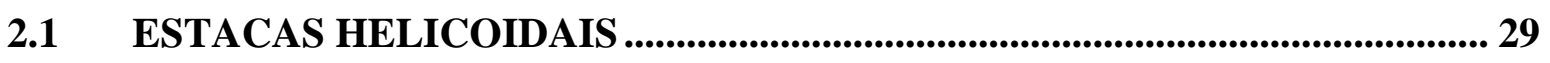

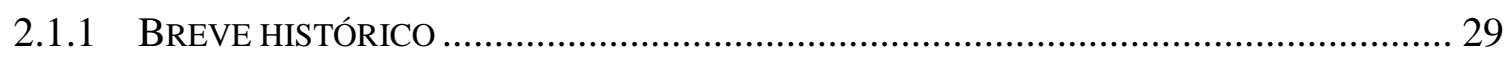

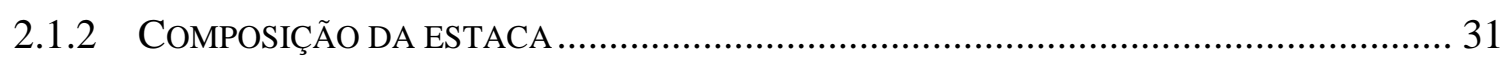

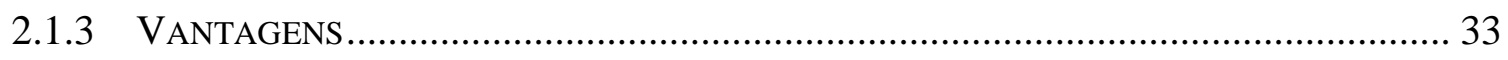

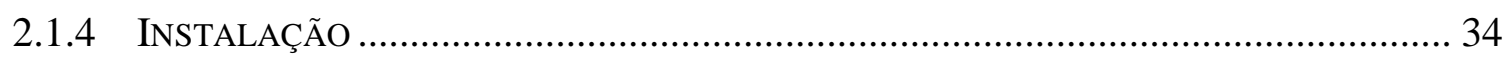

2.2 MÉTODOS DE PREVISÃO DA CAPACIDADE DE CARGA À TRAÇÃO.. 36

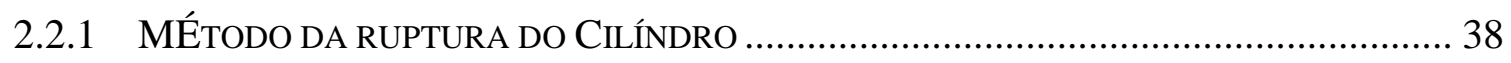

2.2.2 MÉTODO DE RUPTURA POR CAPACIDADES DE CARGAS INDIVIDUAIS ................. 42

2.2.3 MÉTODOS DE CORRELAÇÃO ENTRE TORQUE E CAPACIDADE DE CARGA .................. 46

2.3 EFEITO DA CONFIGURAÇÃO DAS HÉLICES ............................................... 47

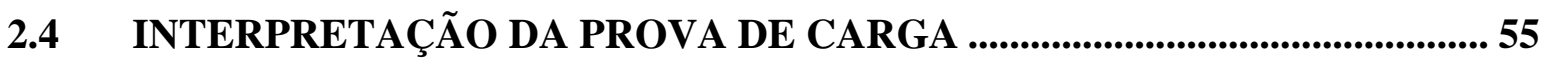

CAPITULO 3 - MATERIAIS E MÉTODOS ...................................................................... 57 


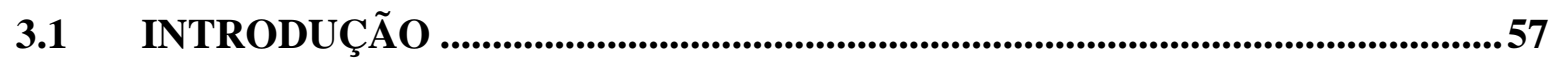

3.2 ÁREA EXPERIMENTAL ....................................................................................

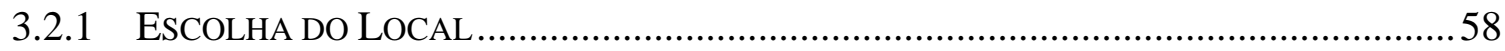

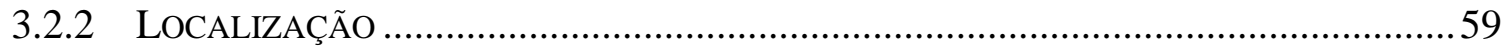

3.2.3 PREPARAÇÃO DO LOCAL..................................................................................... 61

3.2.4 CARACTERIZAÇão GEOLÓGICA ........................................................................... 61

3.3 CAMPANHA DE INVESTIGAÇÃO GEOTÉCNICA ……....................................63

3.3.1 ENSAIOS DE SONDAGEM DE SIMPLES RECONHECIMENTO (SPT) ...........................6 65

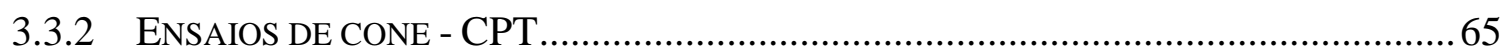

3.4 INSTALAÇÃO DAS ESTACAS ENSAIADAS........................................................68

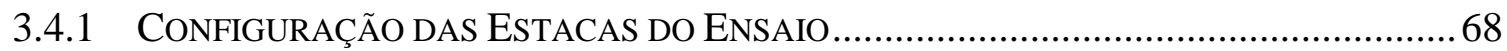

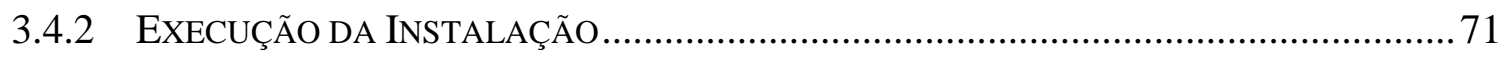

3.5 PROVAS DE CARGA À TRAÇÃO ................................................................73

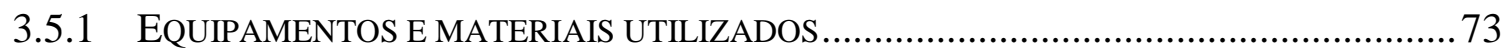

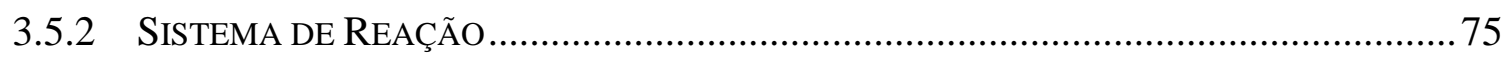

3.5.3 EXECUÇ̃̃O DAS PROVAS DE CARGA...................................................................79

3.6 METODOLOGIA DAS ANÁLISES....................................................................81

CAPITULO 4 - RESULTADOS ...............................................................................................83

4.1 INVESTIGAÇÕES GEOTÉCNICAS ........................................................................83

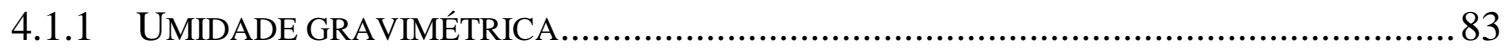

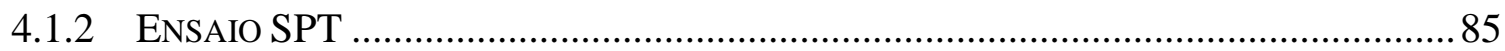

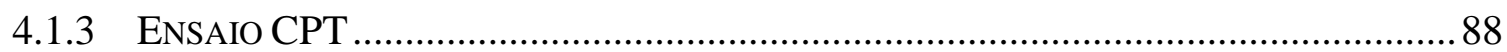

4.1.4 INTERPRETAÇ̃̃o ACLOPADA Do PERFIL GEOTÉCNICO ............................................90

4.2 INSTALAÇÃO DAS ESTACAS ...............................................................................91 
4.2.1 TORQUES DE INSTALAÇÃO

4.3 CURVAS CARGA X DESLOCAMENTO DOS ENSAIOS DE PROVA DE CARGA À TRAÇÃO 100

CAPITULO 5 - ANÁLISE DOS RESULTADOS. 106

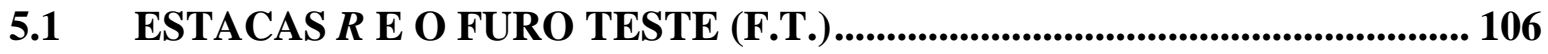
APÊNDICE A - CALIBRAÇÃO DOS EQUIPAMENTOS 155

A.1 CALIBRAÇÃO DO MANDRIL HIDRÁULICO 155

A.2 CALIBRAÇÃO dA AQUISIÇÃO dE DADOS DA CÉLULA DE CARGA. 155 APÊNDICE B - RESULTADOS DE MEDIÇÕES 156

B.1 REGISTRO DAS PRESSÕES DIFERENCIAIS NA INSTALAÇÃO 156 ANEXO A - RELATÓRIO DO ENSAIO DE SONDAGEM DE SIMPLES RECONHECIMENTO. 157

ANEXO B - PROJETO DE FABRICAÇÃO DAS ESTACAS METÁliCAS HELICOIDAIS. 163 


\section{CAPITULO 1 - INTRODUÇÃO}

\subsection{CONTEXTO}

Segundo Carvalho (2007), devido sua simplicidade e rapidez na execução, as estacas helicoidais tem sido cada vez mais utilizadas na engenharia em diversas aplicações e no sistema de distribuição de energia em forma de tirantes que sustentam grandes torres de linhas de transmissão de redes de energia (LT). (Figura 1.1)

Obras deste tipo necessitam de uma fundação que possa ser executada em locais de difícil acesso, e seja capaz de resistir a esforços de tração e de compressão gerados pelos ventos, ação principal atuante neste tipo de estrutura. Além disso, por ser um tipo de estaca que não necessita da remoção do solo para sua aplicação, pode ser instalada com certa agilidade usando equipamentos e mão de obra relativamente simples. Após a sua instalação, ela está pronta para receber carga.

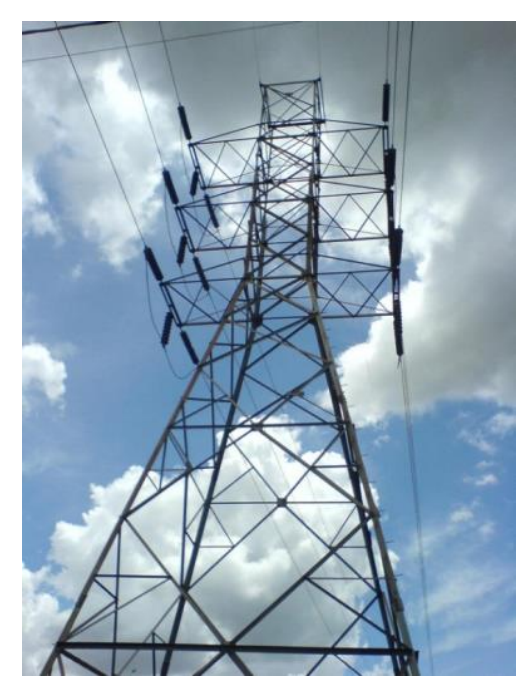

Figura 1.1: Torre de transmissão de linhas de energia

No exterior há registro de aplicações das estacas helicoidais em contenções como solução de atirantamento, porém, no Brasil o maior uso destas é na área de transmissão de energia. Outra vantagem importante é o controle da capacidade de carga através do torque de instalação usado 
na prática, baseados em regras empíricas estabelecidas pela experiência das próprias empresas executoras deste tipo de fundação (TSUHA, 2007).

O controle de capacidade de carga durante a execução de estacas é um tema recorrente em pesquisas do meio acadêmico na busca de melhor confiabilidade das fundações. Contudo, são escassos os estudos sobre o controle na execução e o comportamento de estacas helicoidais em nosso país. Na literatura brasileira destacam-se dois autores que realizaram pesquisas neste tema, Tsuha (2007) e Carvalho (2007).

A partir deste contexto e da crescente utilização deste tipo de estaca no Brasil, conclui-se a necessidade de estudos mais profundos a fim de proporcionar maior conhecimento sobre aspectos relacionados ao comportamento das estacas metálicas helicoidais.

\subsection{RELEVÂNCIA DA PESQUISA}

Algumas empresas nacionais têm usado estacas helicoidais na indústria do petróleo, como ancoragem de gasodutos superficiais (Figura 1.2). Geralmente, isto acontece para evitar que os mesmos flutuem em períodos de cheia, prevenindo danos que possam prejudicar ou inviabilizar o transporte de gases e óleos nas tubulações.

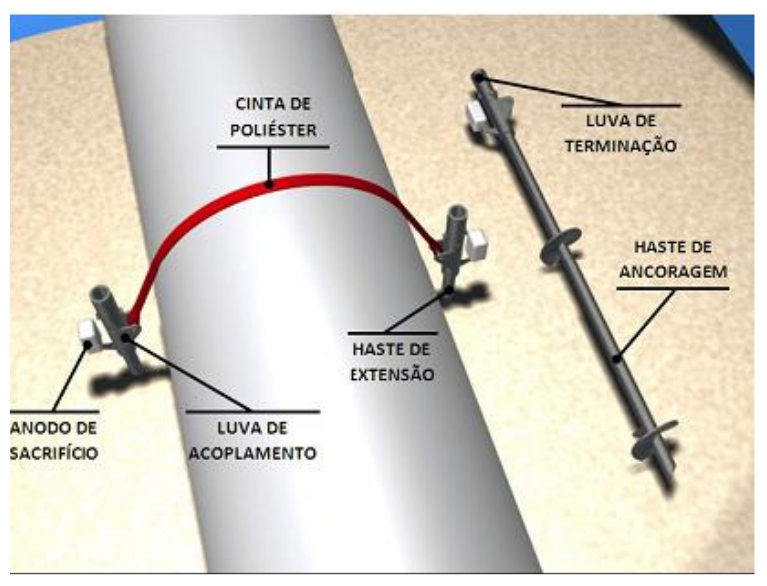

(a)

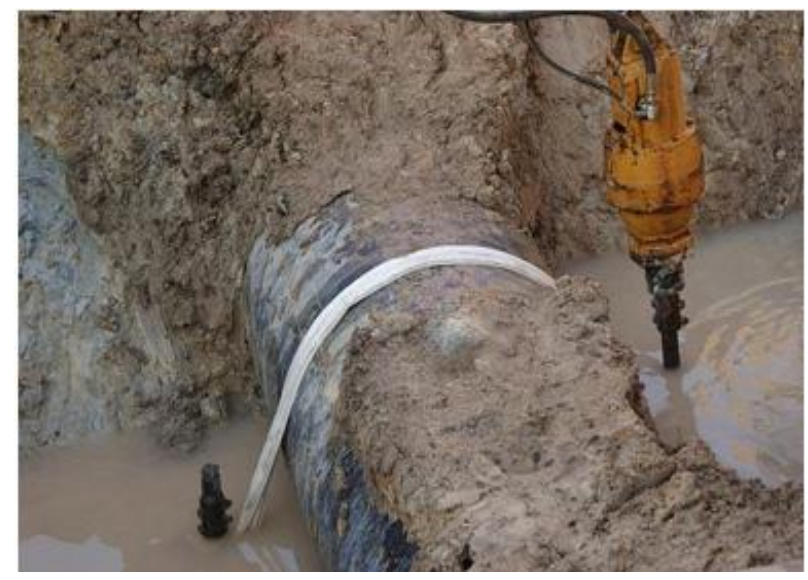

(b)

Figura 1.2: Estaca metálica helicoidal utilizada como ancoragem de dutos em (a) imagem e (b) foto (ASEL-TECH, 2010) 
Empresas nacionais têm procurado o meio acadêmico com o intuito de melhor entender o comportamento deste tipo de estaca quanto as características relevantes de seu projeto e execução. As principais demandas da prática são: melhorar os métodos de cálculo disponíveis e examinar questões essenciais quanto à profundidade de instalação, quantidade e diâmetro das hélices (configuração das estacas).

Neste trabalho foram avaliados o efeito da instalação e da configuração das hélices (diâmetro, número e composição) na capacidade de carga à tração deste tipo de estaca. No entanto, o assunto é vasto e pouco explorado, indicando a necessidade de mais estudos sobre estes efeitos em diferentes tipos de solos, principalmente tropicais.

Por fim, a busca de melhores esclarecimentos sobre o emprego da estaca metálica helicoidal pelo mercado, o escasso número de trabalhos nacionais sobre o tema, a necessidade de aprimorar os métodos de cálculo e o entendimento deste tipo de estaca/ancoragem mostra a relevância deste trabalho e justifica o tema desta dissertação.

\subsection{JUSTIFICATIVAS DO TEMA}

Um maior entendimento sobre a influência da configuração das hélices (diâmetro e quantidade) é essencial em algumas situações práticas e usuais, pois por vezes pode vir a solucionar desafios enfrentados com o uso da estaca helicoidal e viabilizar sua utilização.

Na Figura 1.3 são ilustradas duas situações desfavoráveis ao uso de estacas helicoidais que ocorrem na prática deste tipo de fundação em solos tropicais. O entendimento do comportamento de estacas helicoidais nestes casos é fundamental (Figura 1.3) para decidir em projeto se é viável ou não ancorar as hélices da estaca em solos tropicais porosos e estruturados, encontrados em grande parte da superfície do Brasil. 


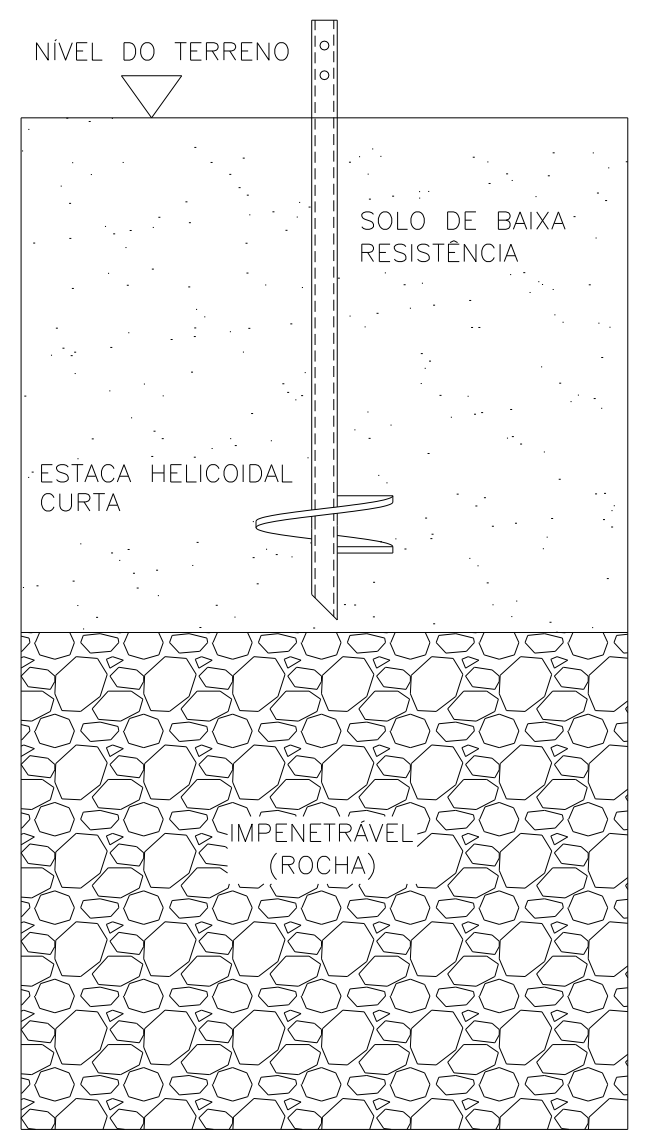

(a)

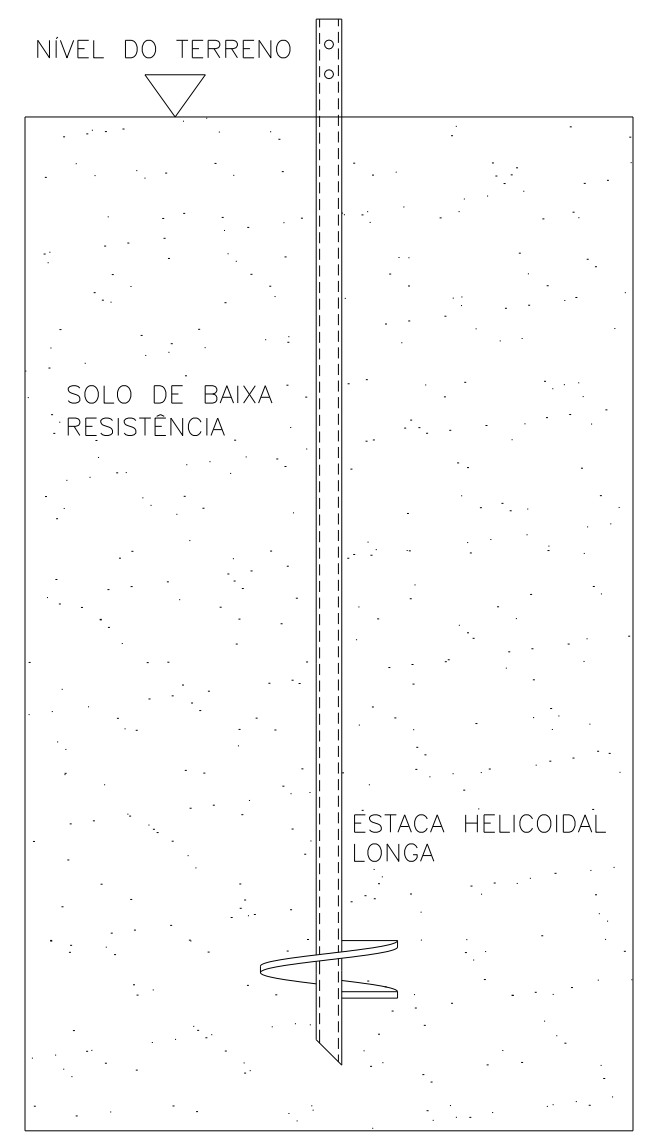

(b)

Figura 1.3: Casos de (a) estacas curtas devido a camadas pouco espessas de solos e (b) estacas longas devido a camadas espessas de solo pouco resistentes.

Estes exemplos ilustram dois casos, o primeiro é no cenário em que a estaca helicoidal está instalada em perfil de solo de baixa resistência e pouco espesso (topo rochoso raso ou presença de matacões). Logo, não se teria como aprofundar mais a estaca em busca de maiores capacidades de carga. O segundo caso ilustra uma estaca longa que já foi aprofundada no perfil de solo, no entanto, ainda se encontra em perfis de solo de baixa resistência e aprofundá-la mais é oneroso e inviável financeiramente devido aos custos das hastes e conexões necessárias. E em ambos os casos é preciso acréscimos na capacidade de carga, pois na situação em que se encontram não atendem as solicitações de projeto.

Nestes casos, soluções de acréscimo no número ou diâmetros das hélices nas estacas podem ser expressivamente vantajosas, viabilizando-se tecnicamente e financeiramente o uso 
destas estacas. Portanto, cabe o aprofundamento deste assunto no meio acadêmico a fim de contribuir na prática das fundações helicoidais.

Os procedimentos de projeto não são normatizados para as estacas helicoidais e segundo Hoyt e Clemence (1989) os métodos de previsão de capacidade de carga mostram grande dispersão em suas estimativas, o que também justifica a importância do estudo sobre o tema.

Para a prática deste tipo de fundação, é de grande importância a calibração dos resultados de torque de instalação destas estacas com a capacidade de carga resultante. Atualmente, esta relação entre torque de instalação e capacidade de carga usada na prática brasileira, para o controle de execução de estacas helicoidais, é resultante da experiência de empresas internacionais instaladoras dessas estacas (maioria dos Estados Unidos ou Canadá) em solos distintos dos solos tropicais brasileiros.

Assim, a necessidade desta pesquisa é justificada basicamente por quatro argumentos:

1. A grande variação entre resultados medidos e calculados (Qact/Qcal) da capacidade de carga deste tipo de fundação (ou ancoragem) quando submetida a esforços de tração. Hoyt e Clemence (1989) mostram a grande dispersão entre valores previstos e medidos da capacidade de carga à tração de estacas helicoidais. (Figura 1.4, Figura 1.5 e Figura 1.6).

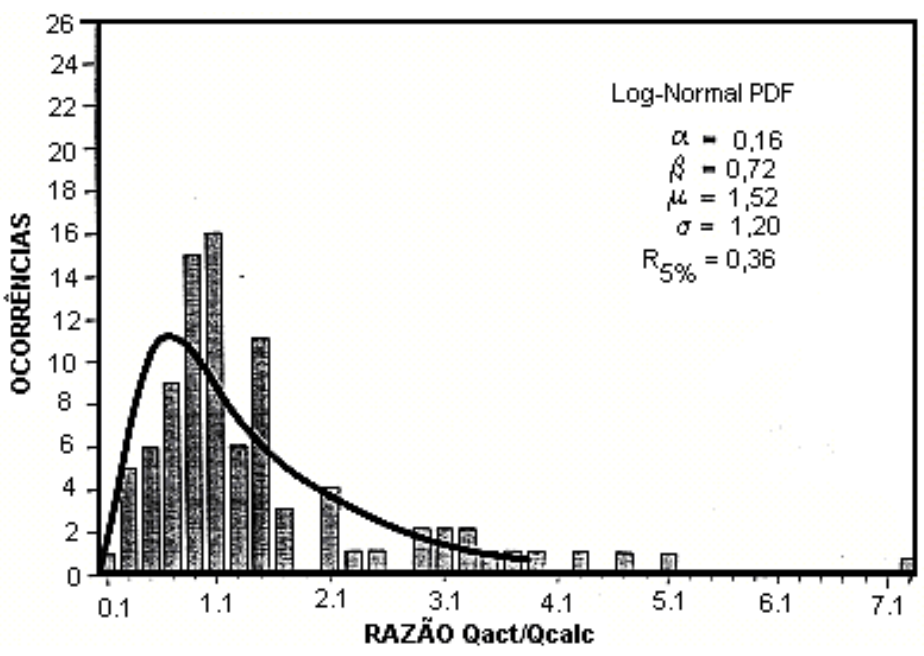

Figura 1.4: Histograma da razão entre capacidade de carga real e capacidade de carga prevista pelo método da ruptura do cilindro $\mathrm{Q}_{\text {med }} / \mathrm{Q}_{\mathrm{cal}}$ (HOYT e CLEMENCE, 1989) 


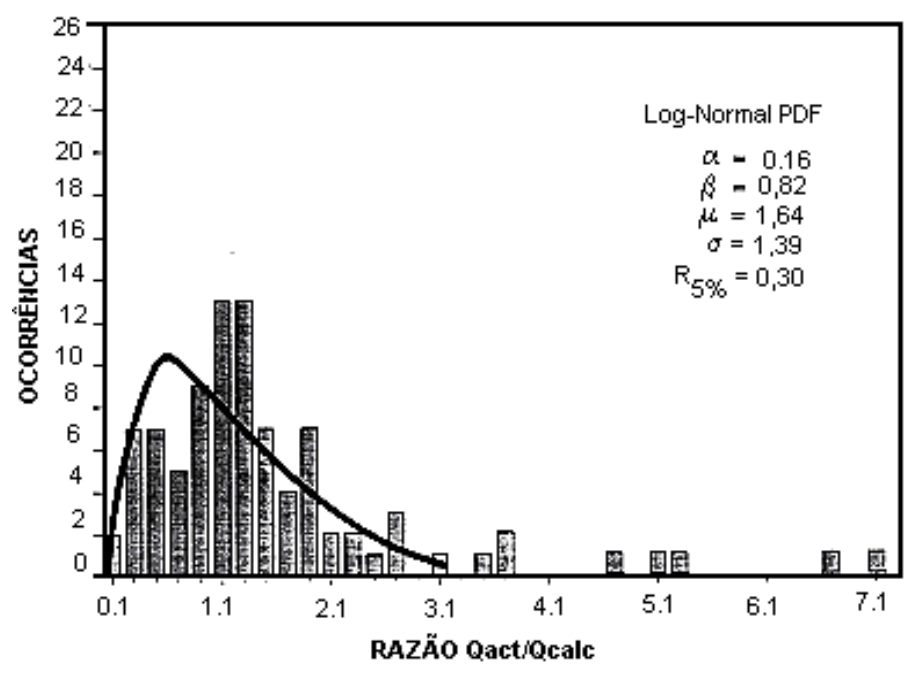

Figura 1.5: Histograma da razão entre capacidade de carga real e capacidade de carga prevista pelo método das capacidades individuais $\mathrm{Q}_{\mathrm{med}} / \mathrm{Q}_{\mathrm{cal}}$ (HOYT e CLEMENCE, 1989)

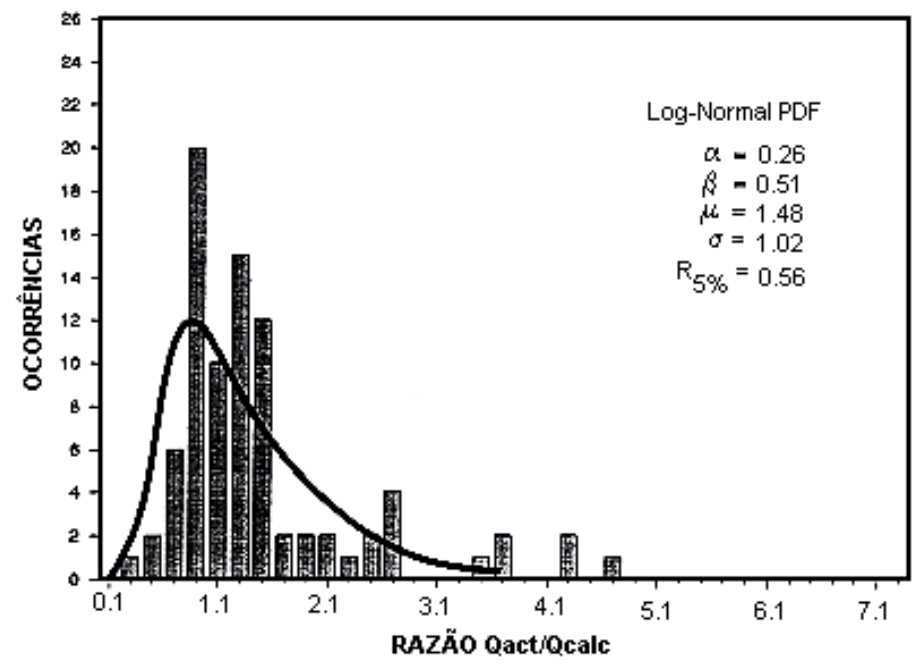

Figura 1.6: Histograma da razão entre capacidade de carga real e capacidade de carga prevista pelo método empírico $\mathrm{Q}_{\text {med }} / \mathrm{Q}_{\text {cal }}$ (HOYT e CLEMENCE, 1989)

2. A busca do mercado nacional ao uso da estaca metálica helicoidal.

3. O trabalho de Tsuha et al (2012) analisou o efeito do número de hélices, com modelos reduzidos de estacas em centrífuga para hélices de igual diâmetro. Os resultados mostram que a perturbação do solo devido ao efeito da instalação estaca faz com que as hélices iguais superiores percam a eficiência. Sendo assim, considera-se importante investigar a influência do número de hélices no comportamento da estaca, e se este comportamento é alterado no caso de hélices com diâmetros variados. 
4. Considerando mesmos níveis de torques de instalação, nos registros nacionais, os ensaios de prova de carga em alguns solos tropicais têm obtido mostrado capacidades de carga menores que os registrados na literatura internacional, e este fato merece estudos e aprofundamentos.

\subsection{OBJETIVOS}

Focando-se na aplicação prática deste tema e na sua contribuição em auxiliar projetos de fundações por estacas metálicas helicoidais, foram definidos alguns objetivos importantes para esta pesquisa, descritos a seguir.

\subsubsection{OBJETIVO GERAL}

O objetivo desta pesquisa é analisar a influência da configuração das hélices no torque de instalação e na capacidade de carga à tração das estacas helicoidais em solo tropical poroso e estruturado da região de São Carlos.

\subsubsection{OBJETIVOS ESPECÍFICOS}

Por meio deste trabalho pretende-se:

- Verificar a influência do número de hélices no torque de instalação e na capacidade de carga da estaca helicoidal;

- Comparar o comportamento entre estacas multi-hélices com diâmetros crescentes (menor na ponta) e com hélices de mesmo diâmetro;

- Quantificar o ganho de capacidade de carga com o aumento do diâmetro da hélice, mantendo-se o mesmo número de hélices.

- Verificar a influência do número de hélices na curva carga x deslocamento vertical obtida em provas de carga à tração. Clemence et al. (1994) observaram que quão maior o número de hélices mais próxima de ruptura nítida é a curva do ensaio. 
- Verificar os métodos de cálculo da capacidade de carga de estacas helicoidais existentes na literatura;

- Averiguar a aplicabilidade do ensaio CPT na avaliação do efeito de instalação das estacas helicoidais no solo acima das hélices (verificar por meio deste ensaio se é possível avaliar as modificações de resistência do solo devido à passagem das hélices). 


\section{CAPITULO 2 - REVISÃO BIBLIOGRÁFICA}

Neste capítulo estão sintetizadas as pesquisas anteriores que forneceram a base teórica necessária para este trabalho. Inicialmente, são abordados aspectos sobre histórico, composição, aplicações, vantagens e modos de instalação da estaca metálica helicoidal, bem como sobre aspectos geotécnicos quanto aos solos tropicais e seu comportamento. Em seguida, é apresentado um levantamento de informações sobre os métodos de previsão mais utilizados de capacidade de carga à tração para a estaca. Além disso, apresenta-se uma revisão sobre prova de carga, suas normas e equipamentos aplicados.

Ainda neste capítulo são mostrados resultados e conceitos importantes ligados ao efeito do número de hélices e seus diâmetros no comportamento da estaca. Referências sobre o efeito da instalação por aplicação de torque na mudança das propriedades do solo e, por conseguinte, na capacidade de carga da estaca são apresentados. Por fim, são apresentados os principais trabalhos que tratam sobre o efeito das hélices e da instalação da estaca no comportamento à tração das estacas metálicas helicoidais.

\subsection{ESTACAS HELICOIDAIS}

A estaca metálica helicoidal é uma fundação segmentada composta por conjunto de hélices individuais ligados por uma haste central metálica. (KNOWLEDGE, 2010). Neste item serão descritas as estacas metálicas helicoidais, focando-se no seu histórico e em suas principais características.

\subsubsection{BREVE HISTÓRICO}

Tem-se como relato mais antigo sobre a estaca helicoidal, o uso de um tronco de madeira com uma hélice de ferro, que foi instalado no terreno por meio da aplicação de um torque sobre seu eixo. (CARVALHO, 2007). 
A invenção das estacas helicoidais deve-se a Alexandre Mitchell, e as mesmas foram utilizadas pela primeira vez na fundação do Farol de Maplin Sands no Rio Tamisa, Figura 2.1, em 1838. Os materiais das primeiras hastes das estacas helicoidais eram ferro ou madeira, enquanto as hélices eram feitas apenas de ferro. (LITTLE, 1961 apud TSUHA, 2007).

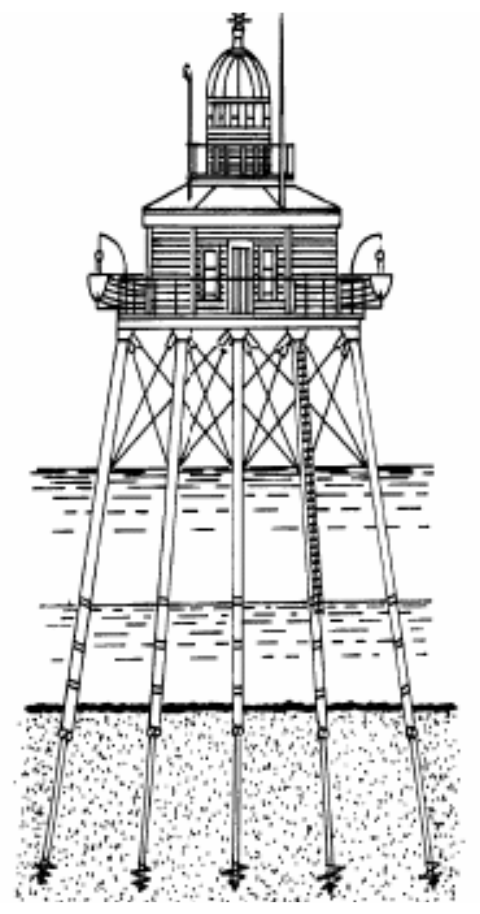

Figura 2.1: Farol com fundação em estaca helicoidal (CHANCE CO., 1994).

Este tipo de fundação também foi utilizado como fundação de diversas pontes em estradas de ferro no sul da França, antes de 1905. (FRICK, 1905 apud TSUHA, 2007).

Mais recentemente, segundo Hoyt e Clemence (1989), vários tipos de construções utilizaram as fundações em estacas metálicas helicoidais, tais como torres de transmissão de energia, linhas de dutos, contenções e obras de terra.

De acordo com Perko (2009), este tipo de estaca possui uma variedade de aplicações, e muitas empresas nacionais e internacionais (continente americano e Europa) têm adotado esta técnica. Além disso, o autor ainda afirma que existem fabricantes de estacas helicoidais na França, nos Estados Unidos da América (EUA), no Japão, na Inglaterra, no Canadá e na Austrália. 
Atualmente, o número de empresas no Brasil que fabricam e instalam esta estaca tem aumentado, com o foco de aplicação em fundações de torres de linhas de transmissão de energia elétrica e como ancoragem de gasodutos, respectivamente.

\subsubsection{COMPOSIÇÃO DA ESTACA}

Mitsch e Clemence (1985) explicam que a estaca metálica helicoidal consiste de uma ou mais hélices de forma circular, feitas em chapa de aço soldadas a um tubo central com um determinado espaçamento entre elas (Figura 2.2 e Figura 2.3).

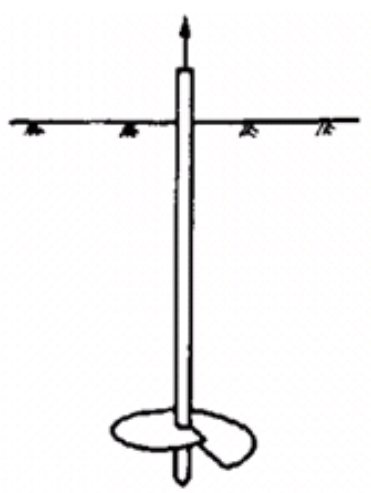

a) SIMPLES

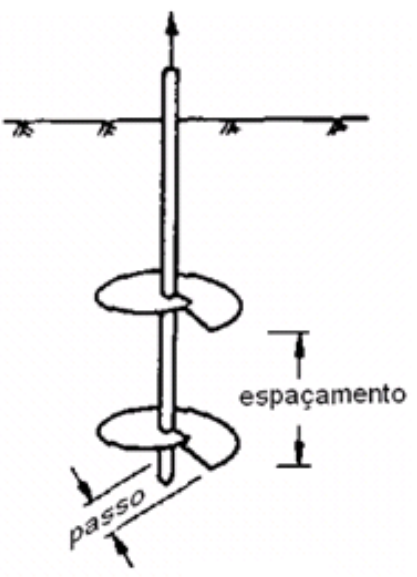

b) MULTI-HÉLICES

Figura 2.2: Estacas metálicas helicoidais simples e multi-hélices (KULHAWY, 1985).

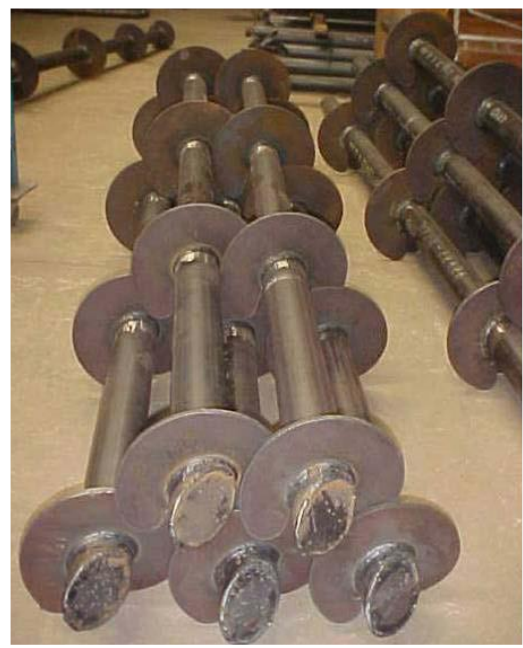

Figura 2.3: Foto de estacas metálicas helicoidais (Carvalho, 2007). 
A estaca metálica helicoidal é constituída por um tubo extenso de aço, soldado em placas circulares, também de aço, em forma de hélices. As hélices são soldadas com controle de espaçamento da curvatura de uma mesma hélice (passo), de forma a ter passos iguais para todas as hélices, para que o distúrbio do solo na instalação seja o menor possível quando em estaca com hélices de mesmo diâmetro.

As estacas podem ter uma hélice ou mais. Quando ela possui mais de uma, é denominada estaca multi-hélices. Já as hélices, podem ter o mesmo diâmetro, ou diâmetros crescentes, o que é mais usual. Não existe um padrão de número de hélices, de espessuras e diâmetros. As dimensões são definidas de acordo com a necessidade de capacidade de carga da estaca na obra. Com isso, cada empresa fabricante determina suas especificações. Os elementos que compõem a estaca são mostrados na Figura 2.4.

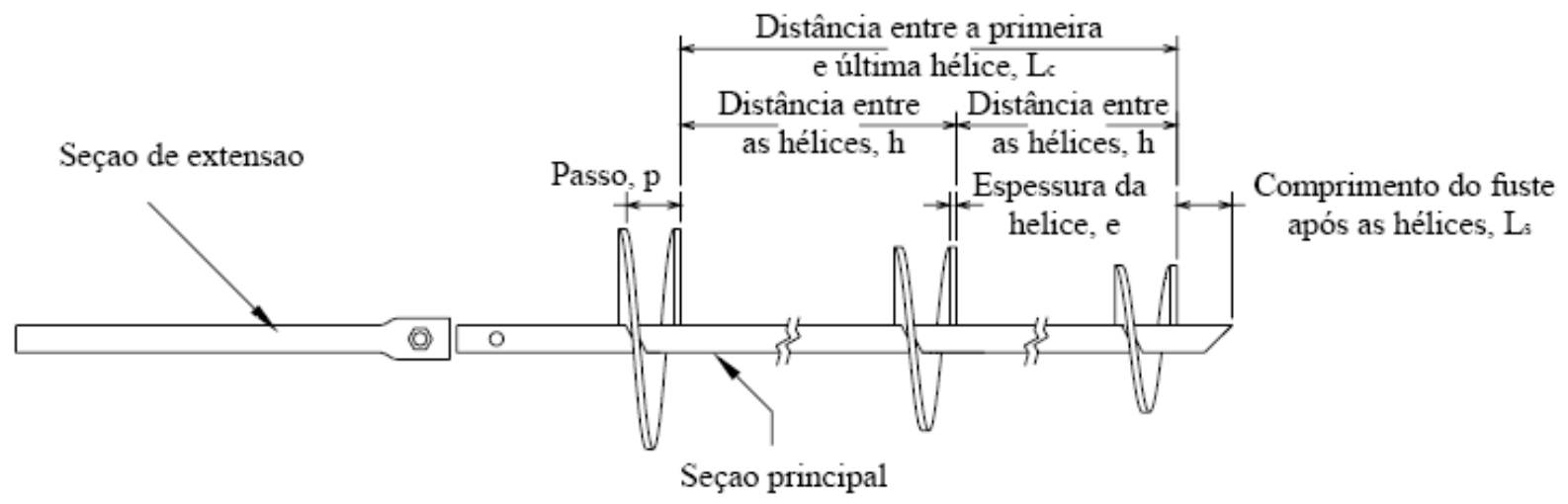

Figura 2.4: Estaca metálica helicoidal e seus elementos constituintes. (CARVALHO, 2007)

Conforme a Figura 2.4, a estaca é composta pelos seguintes elementos:

a) Haste: É o tubo metálico principal da estaca. Sua seção pode ser quadrada sólida, variando os lados de 4 a $5 \mathrm{~cm}$, ou tubular, geralmente entre o diâmetro de 5 a $13 \mathrm{~cm}$. Para facilitar o manuseio e a instalação, as estacas são segmentadas em seções. Ela é dividida em duas seções: a seção principal onde estão soldadas as hélices; e a seção de extensão, que são os tubos conectados ao principal para complementar seu comprimento a fim de atingir a profundidade desejada.

b) Lc: É a distância entre a primeira e a última hélice da seção principal da estaca.

c) Ls: Comprimento da haste abaixo da hélice da ponta. 
d) h: Espaçamento entre as hélices.

e) Passo (p): Espaçamento vertical de um giro completo da hélice. Ele é constante, de forma que o distúrbio do solo na instalação seja o menor possível.

f) Diâmetro (D): As hélices têm diâmetros típicos variando de 15,24 cm a 35,56 cm.

Estacas metálicas helicoidais devem ser protegidas contra corrosão por galvanização ou por outro tipo de proteção. As estacas são produzidas, em geral, com aço galvanizado ou aço do tipo corten (ASTM A36). No Brasil são produzidas estacas com este último tipo de material.

\subsubsection{VANTAGENS}

Segundo Niroumand el al (2012) as estacas helicoidais têm se mostrado um bom sistema de fundações para cargas de compressão e tração.

De acordo com Perko (2009), as principais vantagens das estacas metálicas helicoidais em relação aos outros tipos de fundações são:

- Podem ser removidas em aplicações temporárias;

- São mais fáceis de serem transportadas aos lugares de difícil acesso, comparando-se ao concreto;

- Pode-se determinar a capacidade de carga da fundação por meio de correlações com o torque de instalação;

- Podem ser instaladas em terrenos com elevado nível d'água sem a necessidade de rebaixamento do lençol freático;

- Geralmente levam menos tempo para serem instaladas do que outro tipo de fundação profunda;

- Podem ser instaladas inclinadas para o aumento da resistência lateral;

- Podem ser instaladas com pequenos equipamentos em áreas inacessíveis;

- Durante a instalação, ruídos e a vibração são mínimos;

- São galvanizadas para resistirem à corrosão;

- Elimina as visitas de retorno à obra para remover as formas do concreto; 
- Não é necessário esperar tempo de cura, este tipo de estaca pode ser carregado imediatamente após a sua instalação;

- Não há necessidade de retirada de solo para bota-fora após a sua instalação.

Além das razões citadas anteriormente, considera-se o fato deste tipo de estaca resistir a esforços de tração e de compressão simultaneamente (Figura 2.5), e a rapidez no tempo de instalação quando comparada a outras soluções de fundações para torres de linhas de transmissão de energia. Este tipo de estaca começou a ser utilizada no Brasil, para este fim, no ano de 1998, e seu uso nesta área tem aumentado ao longo do tempo.

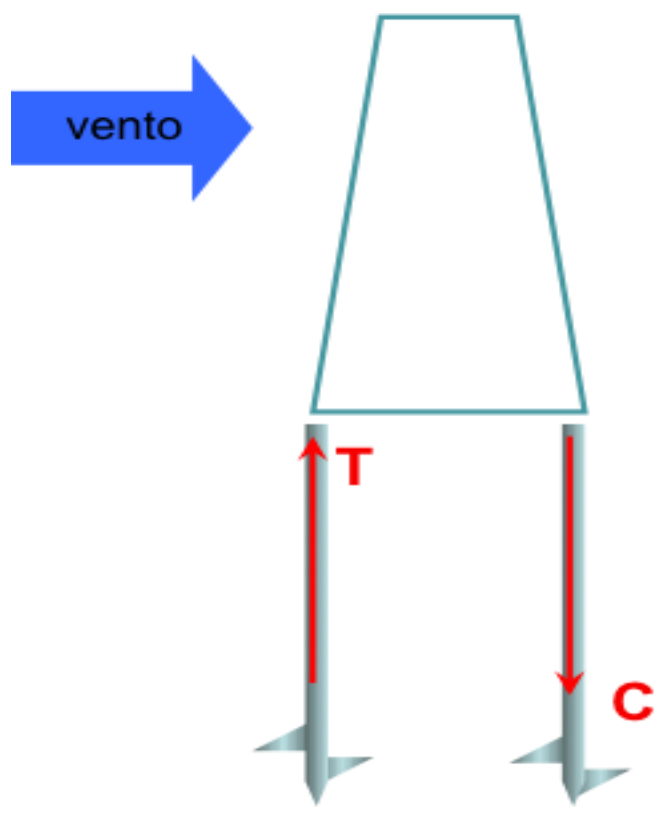

Figura 2.5: Esforços de tração e compressão da estacas helicoidais de torres sob ação de vento.

\subsubsection{INSTALAÇÃO}

As estacas metálicas helicoidais são instaladas no solo por aplicação de torque na haste da estaca e os avanços em profundidade são iguais ao passo da hélice para cada volta completa. (GHALY e HANNA, 1991). Os tubos são emendados conforme a necessidade de se avançar dentro do solo. (Figura 2.6a). Sua instalação termina quando atinge-se uma camada com resistência apropriada. Ela é feita na forma de aparafusamento através de aplicação de torque, medido através de um torquímetro, mostrado na Figura 2.6b. O equipamento de instalação pode ser adaptado à um caminhão ou retro escavadeira. (Figura 2.7) 


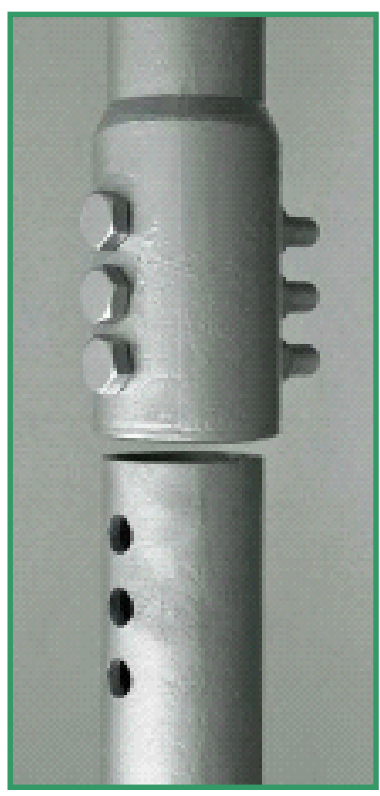

(a)

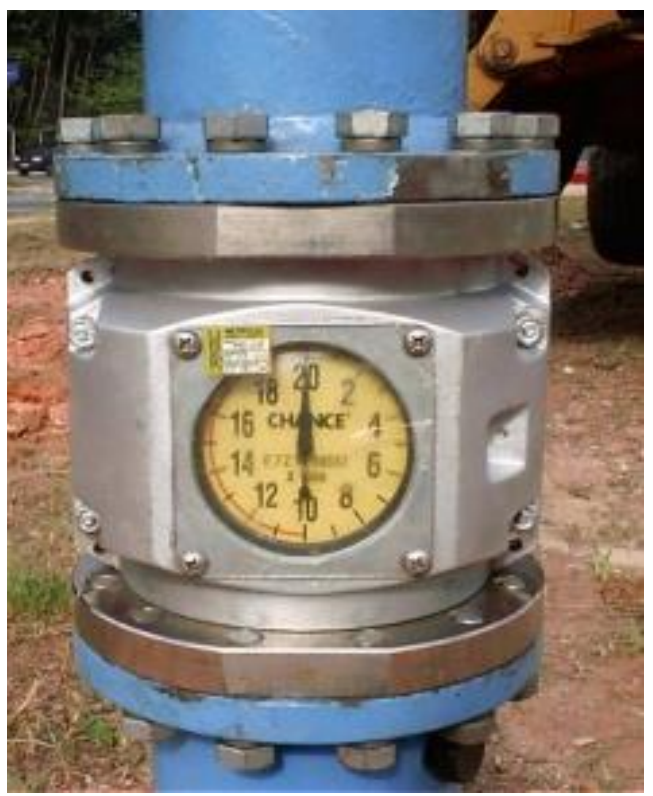

(b)

Figura 2.6: Imagens da (a) conexão parafusada utilizada na ancoragem helicoidal e (a) do torquímetro. (Tsuha, 2007)

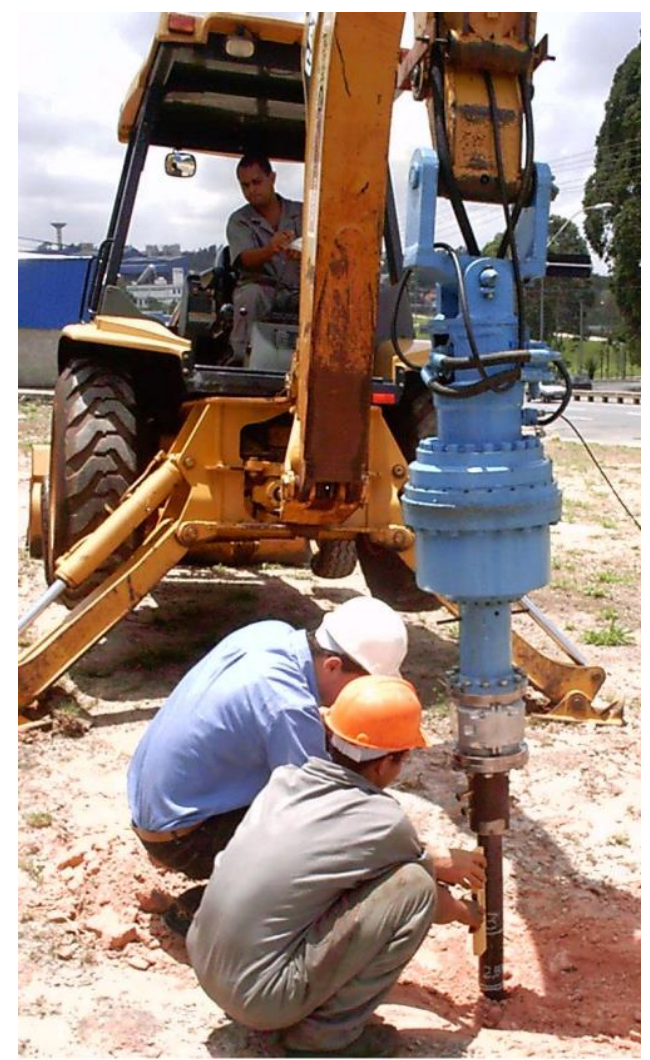

Figura 2.7: Instalação da estaca através de retro escavadeira com torquímetro adaptado. Tsuha (2007) 


\subsection{MÉtOdOS DE PREVISÃo DA CAPACIDADE DE CARGA À TRAÇÃO}

Segundo Hoyt e Clemence (1989) a literatura indica um conjunto de autores cujo o tema de suas pesquisas foram os métodos analíticos para análises e dimensionamento das estacas helicoidais submetidas a esforços axiais de tração. Mitsh e Clemence (1985) e Mooney et al. (1985) apresentaram métodos de previsão de capacidade de carga de estacas helicoidais para solos arenosos e solos argilosos.

Hoyt e Clemence (1989) destacam dois métodos de previsão de capacidade de carga de estacas helicoidais mais utilizados: o método de ruptura do cilindro e o método de ruptura por capacidades de carga individuais. (Figura 2.8)

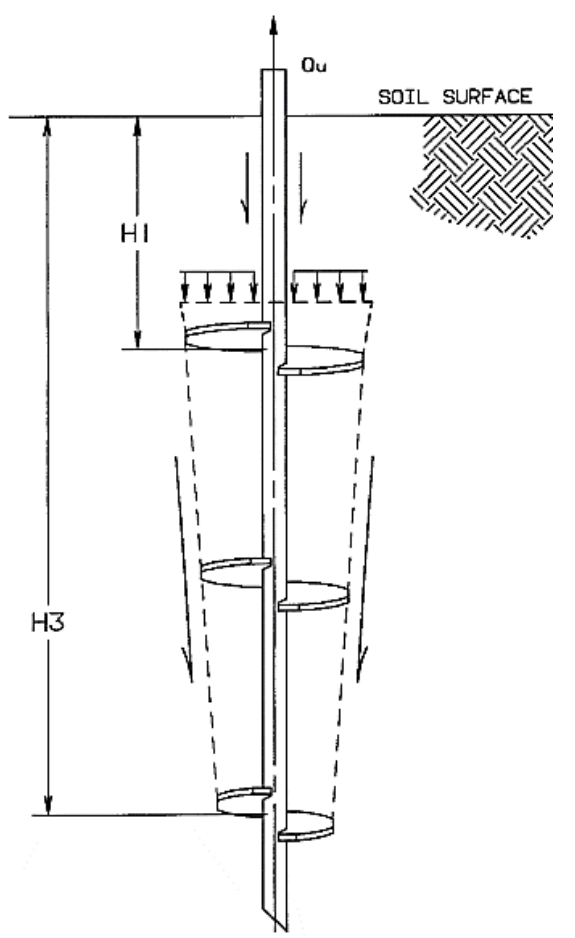

(a)

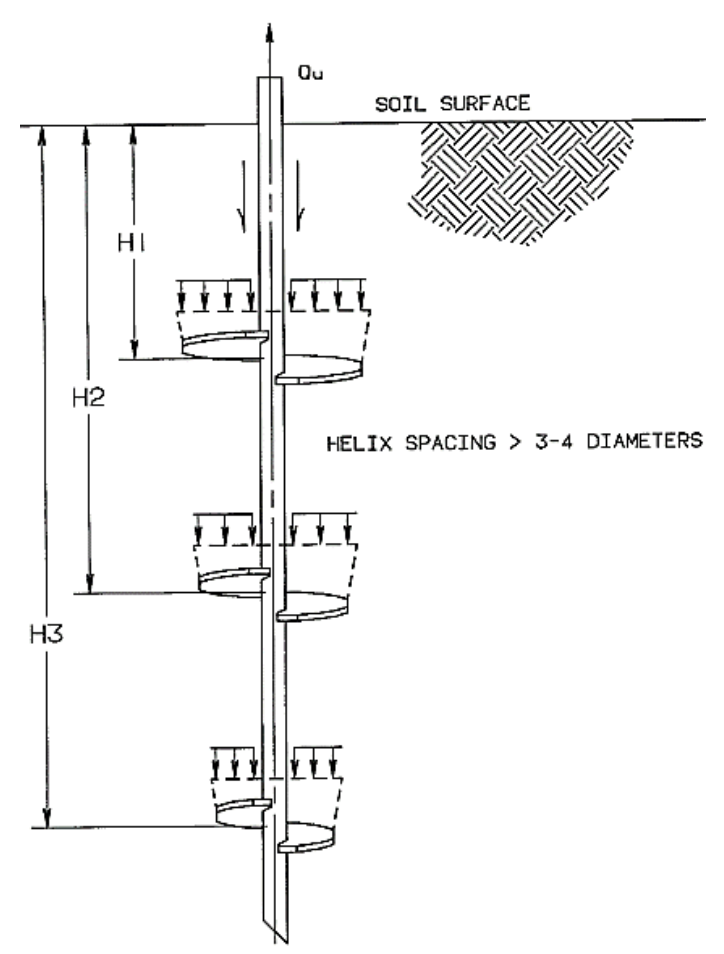

(b)

Figura 2.8: Mecanismo de ruptura (a) do cilindro e (b) capacidades de carga individuais (HOYT e CLEMENCE, 1989) 
Há também um terceiro método geralmente utilizado para estimar a capacidade de carga das estacas helicoidais segundo Hoyt e Clemence (1989), e este outro método é a correlação entre o torque de instalação e a capacidade de carga. Perko e Rupiper (2000) também citam estes três métodos e afirmam que para que se chegue a alguma conclusão, é recomendável utilizar os três modelos de cálculo. Perko e Rupiper. (2000) sugerem que quando possível, a decisão do engenheiro deve ser baseada nos resultados dos três métodos, considerando a confiabilidade dos parâmetros e dados fornecidos.

O que determina qual será o mecanismo de ruptura que ocorrerá na estaca (o da Figura 2.8a ou o da Figura 2.8b) quando carregada é o espaçamento relativo entre as hélices (S/D, onde S é a distância entre hélices e D o diâmetro da hélice inferior) segundo os autores deste parágrafo. Merifield e Smith (2010) mostraram através de simulações numéricas que o mecanismo de ruptura que forma uma superfície resistente que envolve deste a hélice do topo até a hélice da ponta (ruptura por cilindro) ocorre quando o espaçamento relativo entre hélices é pequeno. Hoyt e Clemence (1989) exibem em sua ilustração do comportamento de ruptura por cargas individuais que s/d maiores que 3 ou 4 resultam em mecanismo de ruptura por capacidades de carga individuais (Figura 2.8b). Segundo Lutenegger (2011), a transição entre o comportamento de ruptura cilíndrica e o comportamento da capacidades de carga individuais de estacas multihélices, de hélices de mesma quantidade e diâmetro, em areia ocorre com um espaçamento entre hélices em torno de 3D.

As estacas helicoidais quando usadas para resistir esforços de tração trabalham como ancoragens. O que distingue o comportamento entre ancoragens profundas e rasas é a profundidade relativa (H/D, onde $\mathrm{H}$ é a profundidade de enterramento e $\mathrm{D}$ o diâmetro da placa de ancoragem), e a densidade relativa do solo. Uma estaca helicoidal é considerada ancoragem profunda, se, quando carregada em tração, a superfície de ruptura acima da hélice de topo não atingir a superfície do terreno. Diferentemente, será denominada rasa quando a superfície de ruptura acima da hélice de topo atinge o nível do terreno.

Merifield (2011) comenta que os métodos usados para previsão do comportamento de estacas helicoidais são inadequados, e que um melhor entendimento do comportamento deste tipo de estaca aumentaria a confiabilidade do projeto e a aceitação de estacas helicoidais como uma alternativa econômica se segura de fundação. Segundo Merifield e Smith (2010) os métodos de 
previsão semi-empíricos existentes são insuficientes e geram resultados excessivamente sub ou super conservadores.

Segue as explicações mais detalhadas de cada um dos métodos.

\subsubsection{MÉTODO DA RUPTURA DO CILÍNDRO}

O método de ruptura do cilindro foi desenvolvido para ancoragens rasas e profundas. Mitsch e Clemence (1985) estudaram a superfície de ruptura do solo em torno da estaca helicoidal na carga última por meio de ensaios em modelos instalados em areia. Neste artigo são mostradas abaixo apenas as expressões para estimativa da capacidade de carga à tração de estacas helicoidais profundas, pois foi a configuração padrão das estacas ensaiadas nesta pesquisa.

Nas estacas multi-hélices a profundidade relativa é obtida através da razão H1/D1 (H1 é a profundidade da hélice do topo, e D1 é o diâmetro externo da hélice do topo).

Segundo Mitsch e Clemence (1985) a superfície de ruptura idealizada em torno da estaca helicoidal profunda instalada na areia está ilustrada na Figura 2.9 e a capacidade de carga à tração (Qu) é composta pelas parcelas da equação 1:

$$
\mathrm{Qu}=\mathrm{Qs}+\mathrm{Qp}+\mathrm{Qf}
$$

onde:

- $\mathrm{Qs}=$ resistência por atrito entre o tubo da ancoragem e o solo acima da hélice de topo.

- $\mathrm{Qp}=$ resistência à ruptura acima da hélice de topo.

- $\mathrm{Qf}=$ resistência por atrito na superfície cilíndrica formada entre as hélices de ponta e de topo. 


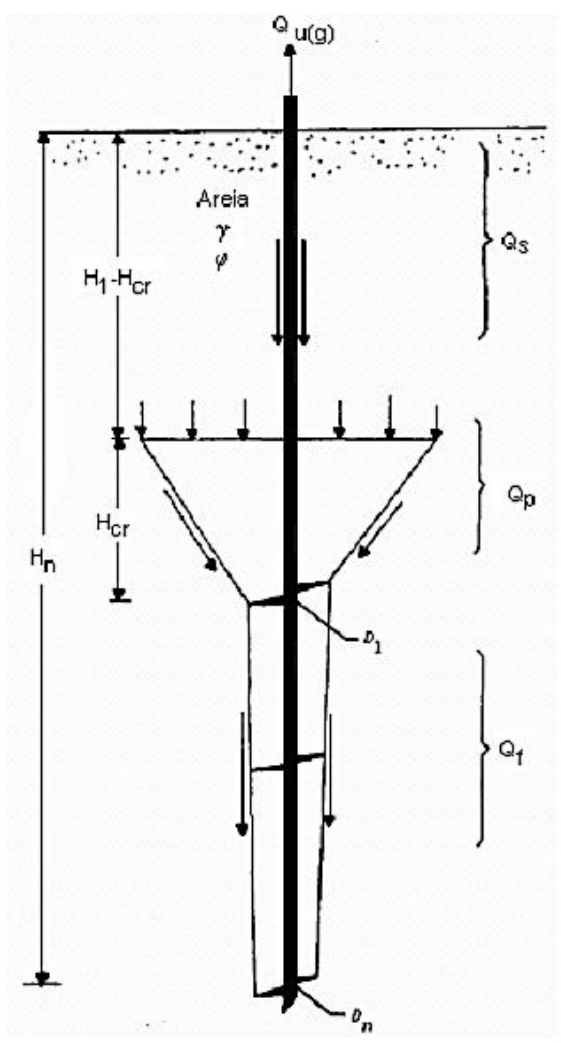

Figura 2.9: Superfície de ruptura idealizada por Mitsch e Clemence (1985) em areias para condição de fundação profunda (DAS, 1990)

Segundo Mitsch e Clemence (1985) o peso da estaca helicoidal é insignificante quando comparado a capacidade de carga da estaca da estaca, logo, ela não é considerada nas parcelas contribuintes na capacidade de carga à tração da estaca, conforme apresentada na equação.

A capacidade de carga à tração de estacas helicoidais profundas em areia podem ser calculadas, segundo Mitsch \& Clemence (1985), pela equação 2, e para argilas pela equação 3, e para siltes pela equação 4, segundo Mooney et al. (1985).

$$
\begin{gathered}
\mathrm{Q}_{\mathrm{u}}=\gamma^{\prime} H_{1} A_{1} N_{q u}+\frac{\pi}{2} D_{a} \gamma^{\prime}\left(H_{n}{ }^{2}-H_{1}{ }^{2}\right) K_{u} \tan \phi+p_{s} H_{1}\left(\frac{\gamma^{\prime} H_{1}}{2}\right) K_{u} \tan \phi \\
\mathrm{Q}_{\mathrm{u}}=A_{1} c N_{c u}+\pi D_{a} c\left(H_{n}-H_{1}\right)+p_{s} H_{1} C_{a} \\
\mathrm{Q}_{\mathrm{u}}=\gamma^{\prime} H_{1} A_{1} N_{q u}+A_{1} c N_{c u}+\frac{\pi}{2} D_{a} \gamma^{\prime}\left(H_{n}{ }^{2}-H_{1}{ }^{2}\right) K_{u} \tan \phi+\pi D_{a} c\left(H_{n}-H_{1}\right) \\
+p_{s} H_{1} C_{a}+p_{s} H_{1}\left(\frac{\gamma^{\prime} H_{1}}{2}\right) K_{u} \tan \phi+p_{s} H_{1} C_{a}
\end{gathered}
$$


onde:

- $\mathrm{Ku}=$ coeficiente de empuxo (Figura 2.10)

- $\mathrm{A} 1=$ área da hélice superior

- $\mathrm{H}_{1}=$ profundidade da hélice superior

- Dn e Hn = diâmetro e profundidade da hélice inferior (da ponta)

- $\mathrm{Da}=$ diâmetro médio das hélices

- $\quad \mathrm{Nqu}=$ fator de capacidade de carga à tração para areias (Figura 2.13)

- $\quad \mathrm{Ncu}=$ fator de capacidade de carga à tração para solo coesivo (Valor de 9 para estacas profundas)

- $\quad$ ps = perímetro do tubo da estacas

- $\mathrm{Ca}=$ adesão ao longo do tubo da estaca

- $\phi=$ ângulo de atrito do solo

\section{- Coeficiente de Empuxo na carga última (Ku)}

Mitsch e Clemence, (1985) apresentam os valores de Ku recomendados por Meyerhof e Adams (1968) para placas enterradas sob solicitações de tração na Figura 2.10. Ao mesmo tempo, comparam com os valores que os autores recomendam para as estacas helicoidais.

Os valores de $\mathrm{Ku}$ segundo Mitsch e Clemence, (1985) consideram o método executivo das estacas helicoidais, instaladas pela aplicação de torque e por sua vez revolvem o solo com a instalação, decrescendo os resultados de Ku. Por outro lado, os dados de Meyerhof e Adams (1968) são para placas, onde o método executivo é através de escavação e re-aterro compactado, gerando melhorias no comportamento do solo, obtendo-se assim, maiores valores de $\mathrm{Ku}$. Portanto, Ku de Mitsch e Clemence, (1985) são expressivamente menores que os recomendados por Meyerhof e Adams (1968). 


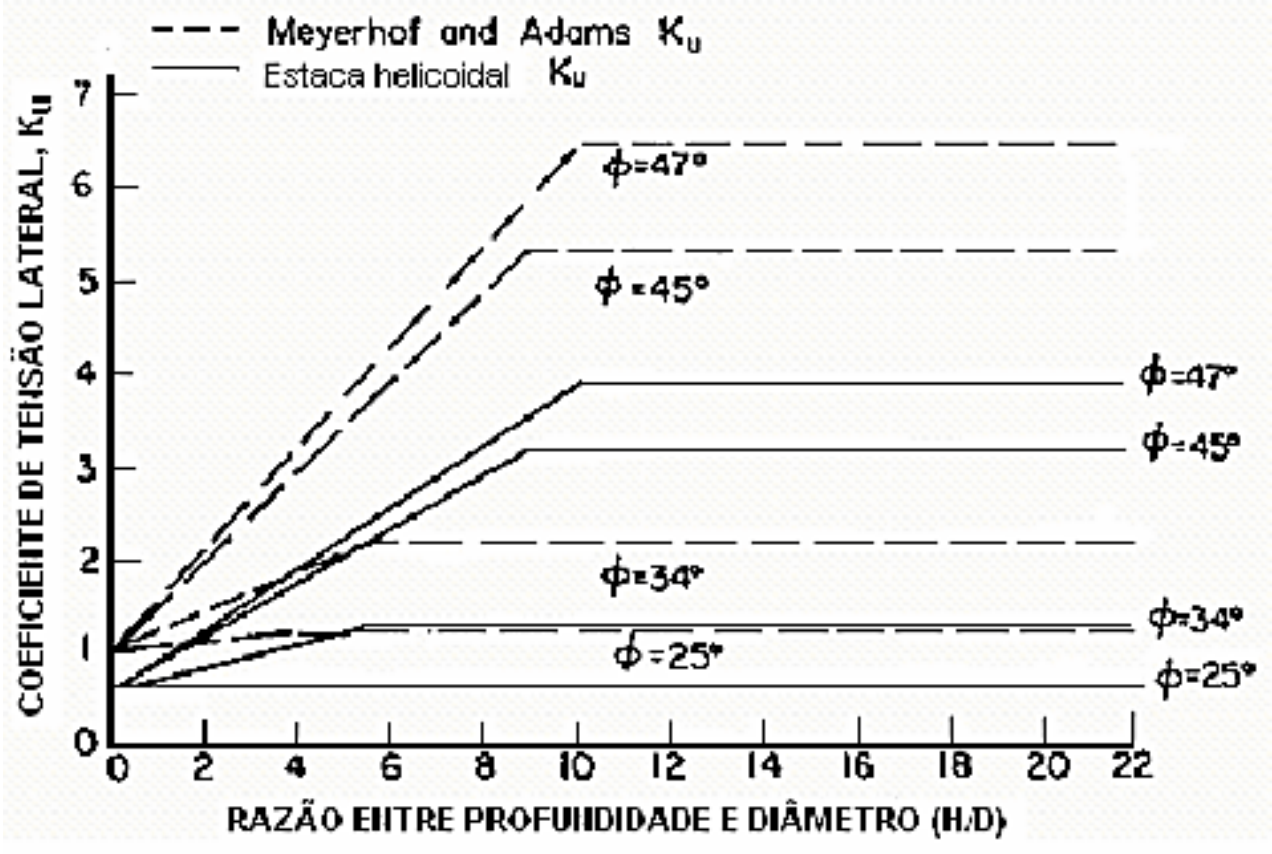

Figura 2.10: Coeficientes de empuxo à tração na carga última $\left(\mathrm{K}_{\mathrm{U}}\right)$ para fundações em estacas helicoidais solicitadas à tração (Mitsch e Clemence, 1985)

Observa-se na Figura 2.10 que o valor de $\mathrm{Ku}$ varia com a profundidade relativa da estaca helicoidal e com o ângulo de atrito do solo. No entanto, a partir de determinada profundidade relativa (H/D) os valores de $\mathrm{Ku}$ são constantes, não acrescendo mais com a profundidade da estaca. Neste momento, a estaca passa de um comportamento de fundação rasa para profunda. É de interesse apenas os resultados do comportamento de fundações profundas, então, segue estes valores na Tabela 2.1 para estacas helicoidais profundas.

Tabela 2.1: Valores de Ku versus ângulos de atrito de solo $\varphi$ para estacas helicoidais profundas (Mitsch e Clemence, 1985)

\section{Ângulo de atrito do solo Ku recomendados para $\varphi$ (graus) Estacas Profundas}

\begin{tabular}{cc}
\hline 25 & 0,7 \\
\hline 30 & 0,9 \\
\hline 35 & 1,5 \\
\hline 40 & 2,35 \\
\hline 45 & 3,2
\end{tabular}




\subsubsection{MÉTODO DE RUPTURA POR CAPACIDADES DE CARGAS INDIVIDUAIS}

O método denominado como o das capacidades de cargas individuais assume que a ruptura do sistema estaca-solo ocorre em cada hélice individualmente. Assim, a capacidade de carga, $\mathrm{Q}_{\mathrm{u}}$, é calculada pela soma da capacidade de carga de cada hélice, $\mathrm{Qui}_{\mathrm{u}}$.

$$
Q_{u}=\sum Q_{u i}
$$

onde:

- $\mathrm{Qu}=$ capacidade de carga total da ancoragem multi-hélices

- Qhi = capacidade de carga individual de cada hélice

Neste texto é apresentado o método de cálculo das Capacidades Individuais, para o caso de capacidade de carga à tração.

Para a utilização deste método, é necessário que as hélices estejam afastadas o suficiente umas das outras para evitar a sobreposição das zonas de ruptura. A A.B. Chance Company considera que um espaçamento entre as hélices de 3 vezes o diâmetro $D$ ou superior $(S / D \geq 3)$ é suficiente para garantir a independência na performance individual de cada hélice.

De acordo com Clemence et al. (1994), o método da A. B. Chance Company assume que a ruptura ocorre sobre cada hélice individualmente e a capacidade de carga total é dada pela soma das resistências individuais acima de cada hélice, conforme a equação 6 .

$$
Q_{u}=\sum A_{h i} \cdot\left(c_{i} \cdot N_{c u}+q_{i} \cdot N_{q u}\right) \leq Q_{\text {estrutural }}
$$

onde:

- Qhi = capacidade de carga à tração de cada hélice

- Ahi = área da hélice projetada

- $q=$ pressão efetiva do solo acima da hélice

- $\mathrm{i}$ = número correspondente à hélice 
- $\quad$ ci = coesão não-drenada do solo da hélice

- $\quad \mathrm{Ncu}=$ fator de capacidade de carga em argila, valor de 9 para estacas profundas.

- $\quad \mathrm{Nqu}=$ fator de capacidade de carga do solo na hélice (Figura 2.13)

- Qestrutural = limite superior determinado pela resistência estrutural da hélice.

- Fator de Capacidade de Carga à Tração

Segundo Das et al (1976) o fator de capacidade de carga sob esforços de tração pode ser expresso em sua forma adimensional pela equação 7 a seguir.

$$
N_{q u}=\frac{P_{u}}{\gamma \cdot A \cdot H}
$$

onde,

- $\quad \mathrm{Nqu}=$ fator de capacidade de carga do solo na hélice (Figura 2.13)

- $\gamma=$ Peso específico do solo

- $\mathrm{A}=$ área da hélice do topo da estaca

- $\mathrm{H}=$ profundidade da hélice do topo da estaca

O gráfico do fator de capacidade de carga (Nqu) para solos não-coesivos apresentado na Figura 2.11 é extraído de Mitsch e Clemence (1985) e mostram os resultados de Meyerhof e Adams (1968) dentre outros pesquisadores na literatura. 


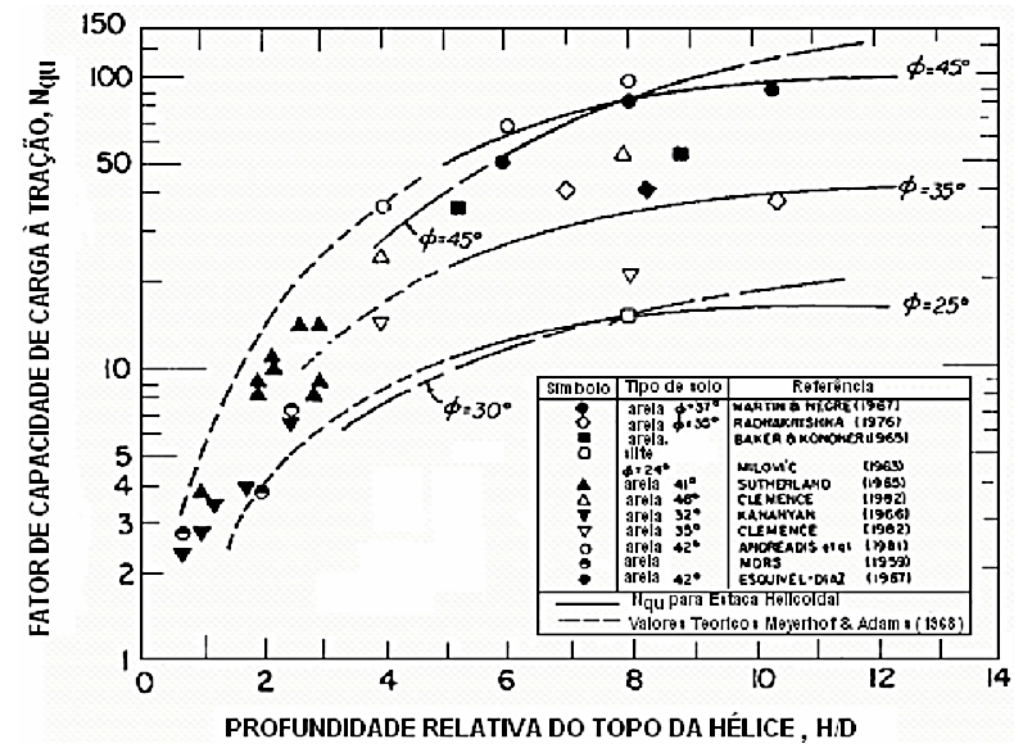

Figura 2.11: Fator de capacidade de carga à tração (Nqu) versus razão H/D para estacas helicoidais em areia (MITSCH E CLEMENCE, 1985)

É perceptível que o valor de Nqu é dependente da profundidade relativa (H/D) da estaca helicoidal e do coeficiente de atrito do solo $(\Phi)$. No entanto, similar ao discutido para $\mathrm{Ku}$, a fundação helicoidal que interessa é apenas a profunda. Segue um gráfico de Das et al (1976) sobre Nqu na Figura 2.12.

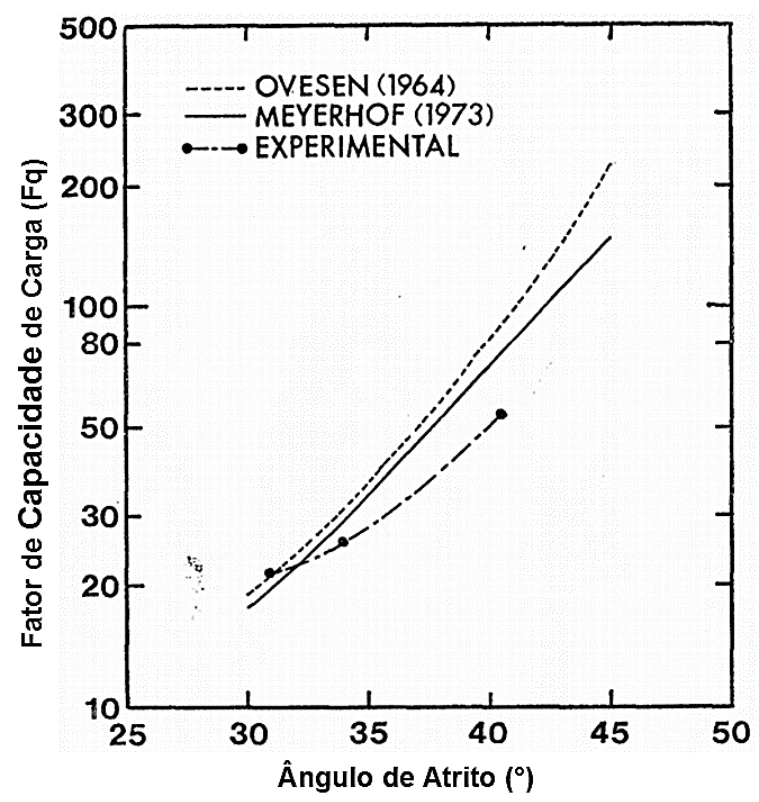

Figura 2.12: Fator de Capacidade de Carga versus ângulo de atrito do solo (DAS et al 1976) 
Os valores de Nqu apresentados por Das et al (1976) e por Mitsch e Clemence (1985) são elevados para a aplicação às estacas helicoidais, pelo mesmo motivo arguido ao Ku.

Chance (2003) ajustou um fator de capacidade de carga à tração para as estacas helicoidais. Este fator é adaptado de Meyerhof (1976) com base na experiência da A. B. Chance Company com estacas helicoidais, obtendo assim a equação 8.

$$
N_{q}=0.5 \cdot\left(12 \cdot \varphi_{i}\right)^{\varphi_{i} / 54}
$$

Onde pi é o ângulo de atrito interno do solo na profundidade da hélice i. A relação entre ângulo de atrito interno e fator de capacidade de carga à tração resultante da equação acima é mostrada na Figura 2.13 da Chance (2003).

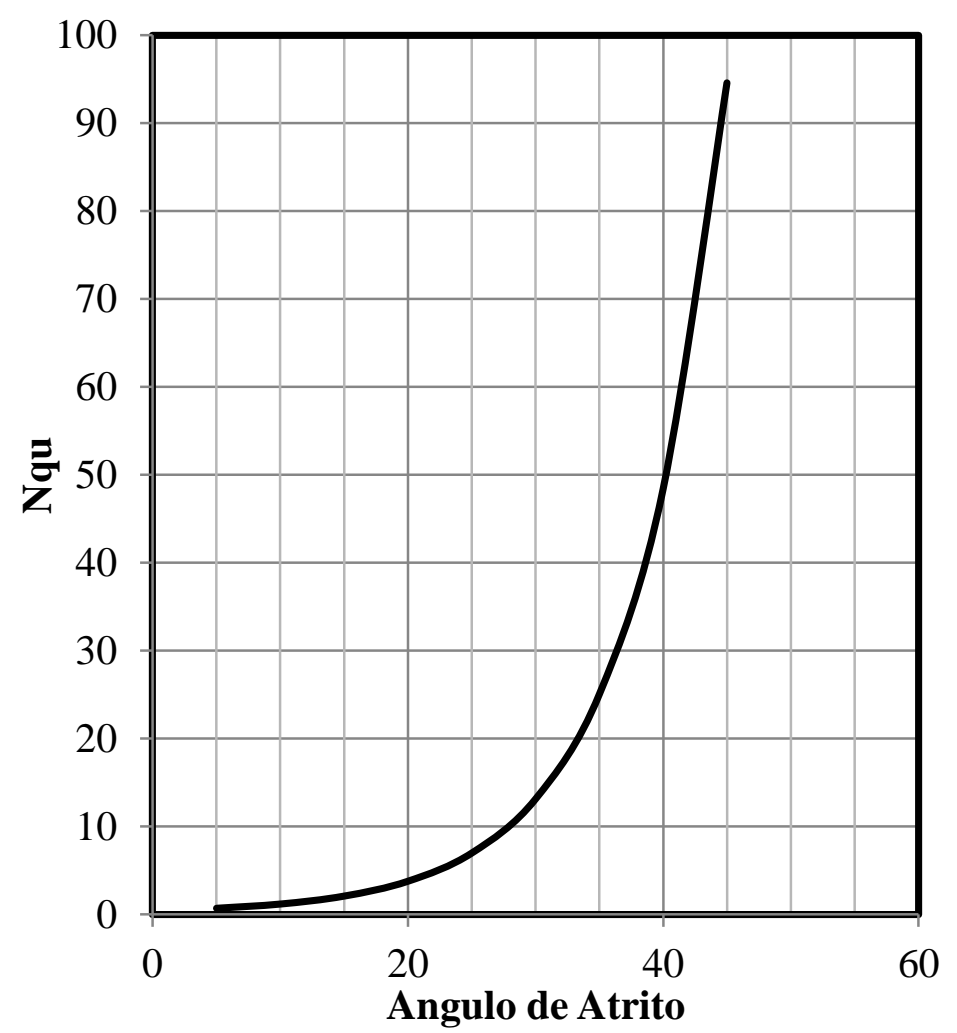

Figura 2.13: Relação entre ângulo de atrito interno e fator de capacidade de carga à tração (modificado de CHANCE, 2003) 


\subsubsection{MÉTODOS DE CORRELAÇÃO ENTRE TORQUE E CAPACIDADE DE CARGA}

A Chance (1994) tem difundido a ideia de Wilson (1950) apud Tsuha (2007) de que o torque requerido para a instalação da estaca helicoidais é proporcional a capacidade de carga à tração e à compressão. Segundo Chance (1994) a equação 9 representa a modelo empírico desta correlação.

$$
Q_{u}=K_{T} \cdot T
$$

onde,

- $\mathrm{Q}_{\mathrm{u}}=$ Capacidade de carga à tração $(\mathrm{kN})$

- $\mathrm{K}_{\mathrm{T}}=$ Fator de torque $\left(\mathrm{m}^{-1}\right)$

- $\mathrm{T}=$ Torque final de instalação (kN.m)

Este método é útil a previsão da capacidade de carga à tração, além de ser uma ferramenta de controle de qualidade, conforme Tsuha e Aoki (2011).

Segundo Chance (1994) o valor de Kt pode variar de 10 a $66 \mathrm{~m}^{-1}$ e depende das condições do solo e da geometria da estaca helicoidal. Quanto a influência do solo, o valor do torque para um mesmo $\mathrm{N}_{\mathrm{SPT}}$ aumenta com a profundidade de instalação da estaca.

Hoyt e Clemence (1989) recomendam Kt conforme Tabela 2.2 e comentam que apesar deste método ter sido desenvolvido empiricamente e da necessidade de maiores esclarecimentos com base teórica, esta correlação tem sido utilizada com sucesso na construção de milhares de estacas durante duas décadas (Hoyt e Clemence, 1989).

Tabela 2.2: Valores recomendados de $\mathrm{K}_{\mathrm{T}}$ em função do diâmetro do fuste da estaca (HOYT e CLEMENCE, 1989).

\begin{tabular}{c|c}
\hline Diâmetro do fuste & $\mathrm{K}_{\mathrm{T}}$ \\
\hline$<89 \mathrm{~mm}$ & $33 \mathrm{~m}^{-1}$ \\
$89 \mathrm{~mm}$ & $23 \mathrm{~m}^{-1}$ \\
$219 \mathrm{~mm}$ & $9,8 \mathrm{~m}^{-1}$ \\
\hline
\end{tabular}


A Ingal Precision Foundations Inc. recomenda valores da Tabela 2.3 segundo Perko (2009).

Tabela 2.3: Valores recomendados de $\mathrm{K}_{\mathrm{T}}$ em função do diâmetro do fuste da estaca (PERKO, 2009).

\begin{tabular}{c|c}
\hline Diâmetro do fuste & $\mathrm{K}_{\mathrm{T}}$ \\
\hline $63,5 \mathrm{~mm}$ & $30 \mathrm{~m}^{-1}$ \\
$76,2 \mathrm{~mm}$ & $23 \mathrm{~m}^{-1}$ \\
\hline
\end{tabular}

Tsuha e Aoki (2010) apresentaram uma expressão teórica simplificada para correlacionar a capacidade de carga à tração com o torque de instalação para estacas metálicas helicoidais em areia. Segundo eles, a correlação entre capacidade de carga e o torque depende do ângulo de atrito residual entre o material das hélices (aço) e o solo. Tsuha e Aoki (2011) mostra que a magnitude de Kt decresce com o acréscimo das dimensões da haste da estaca e do ângulo de atrito do solo arenoso.

Tsuha et al (2007) encontrou Kt entre 14 e $48 \mathrm{~m}^{-1}$ nos seus resultados em areia de modelos físicos em centrífuga, onde verifica forte influência da compacidade da areia no fator torque. Na maioria dos resultados encontrados pelo autor a capacidade de carga e o torque de instalação aumentam com o acréscimo de número e de dimensões das hélices.

Há demais autores que estudaram o tema e desenvolveram expressões analíticas com base em modelos teóricos para correlacionar o torque com a capacidade de carga como: Tsuha et al (2007) Ghaly e Hanna, (1991); Perko, (2009); e Rao et al., (1989), no entanto, estas teorias não serão abordadas nesta pesquisa.

\subsection{EFEITO DA CONFIGURAÇÃO DAS HÉLICES}

As estacas helicoidais multi-hélices deste trabalho foram divididas em três modelos distintos (Modelos A, B e C), conforme apresentado na metodologia item 3.4.1- Configuração das Estacas do Ensaio. E para uniformizar o entendimento, as estacas podem ser divididas em duas configurações de hélices distintas, de hélices iguais ou hélices crescentes. 
Utilizando-se a nomenclatura adotada por Lutenegger (2011) tem-se a configuração “cilíndrica" e a "cônica" (Figura 2.4). É denominada de "cilíndrica" a configuração das estacas com hélices iguais, que são as estacas do modelo A. Para a configuração de estacas com hélices crescentes, foi dado o nome de estacas “cônicas", que são as estacas dos modelos B e C. Portanto, quanto à configuração das hélices, as estacas se classificam conforme a Figura 2.14.

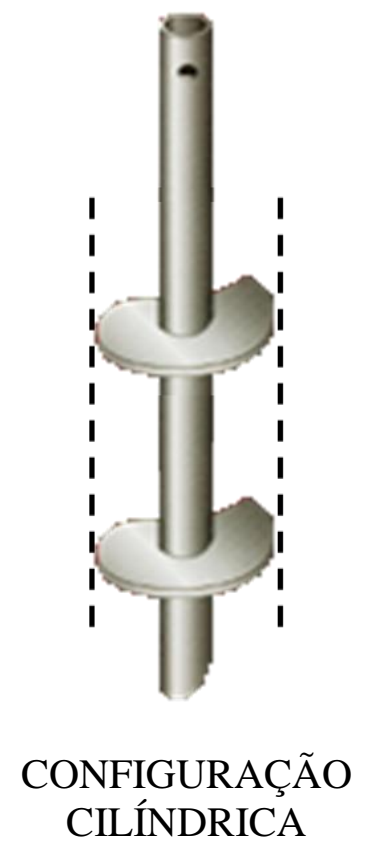

(a)

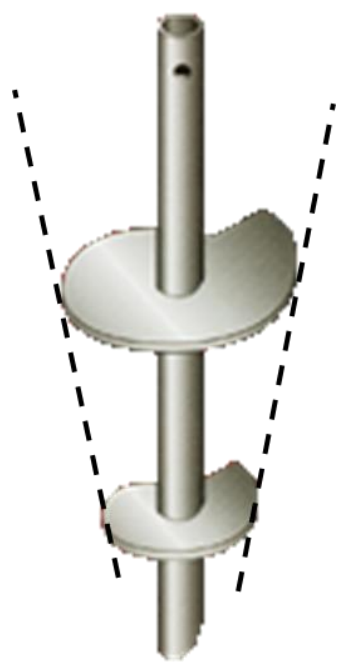

CONFIGURAÇÃO CÔNICA

Figura 2.14: Modelos das estacas multi-hélices: (a) Cilíndricas e (b) Cônicas.

CLEMENCE et al. (1994) analisa o efeito do número de hélices na capacidade de carga à tração de estacas helicoidais em areia, para tanto, foram ensaiadas estacas com uma, duas e três hélices (30 cm de diâmetro) instaladas em maciço uniforme de areia (ângulo de atrito igual a $34^{\circ}$, peso específico $15,7 \mathrm{kN} / \mathrm{m} 3$, e profundidade de estacas de 6,1 metros

A Figura 2.15 de Clemence et al. (1994) apresenta as curvas de "carga de tração x deslocamento" resultantes das provas de carga nos três tipos de estacas (com uma hélice, com duas hélices e com três hélices). Este resultados foram obtidos de ensaios em estacas helicoidais instaladas em depósito de areia homogêneo horizontalmente. O comportamento "carga $\mathrm{x}$ deslocamento" e as cargas de ruptura são praticamente idênticos para cada tipo de estaca. 


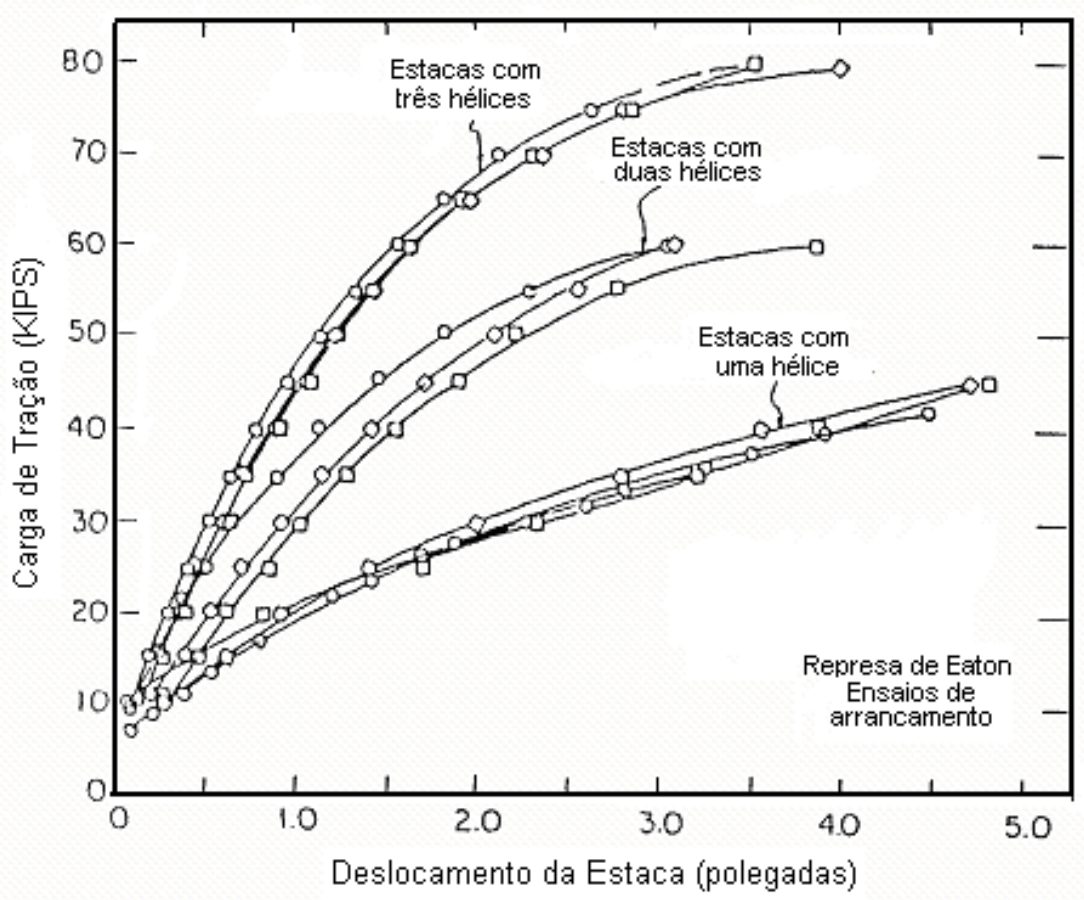

Figura 2.15: Curvas Tensão x Deslocamento das Provas de Carga realizadas represa de Eaton (CLEMENCE et al., 1994).

Nestes ensaios foi observado que a resistência à tração da estaca simples (com uma hélice) e da multi-hélices são diferentes. Nas estacas de uma hélices (simples) é necessário grande deslocamento para mobilização de carga máxima; e o pico de carga das curvas "carga vertical x deslocamento" não é claro. Nas curvas das estacas multi-hélices, é possível observar a tendência de formação de pico na carga máxima. Este resultados levam a crer que o número de hélice influência no comportamento do modo de ruptura da estaca helicoidal.

O módulo de deformabilidade ou elasticidade (E) inicial é a tangente da curva tensão e deformação na origem dos eixos da curva. Nos ensaios de provas de carga têm-se carga versus deslocamento, e a tangente a origem desta é denominado módulo de rigidez normal inicial (K). Quanto maior este módulo, menor é o deslocamento vertical da estaca em um mesmo carregamento, ou seja, maior sua rigidez e melhor seu desempenho carga vertical versus deslocamento. 
A Figura 2.16 mostra a curva de correlação entre o Módulo de Rigidez Normal Inicial (K) e o número de hélices para estacas com uma, duas e três hélices. Os resultados indicam uma relação linear entre o número de hélices e o módulo inicial para este caso particular de solo. No entanto, segundo os autores deste trabalho, a possibilidade de uma relação linear entre o deslocamento da estaca e o número de hélices indica a necessidade de investigação.

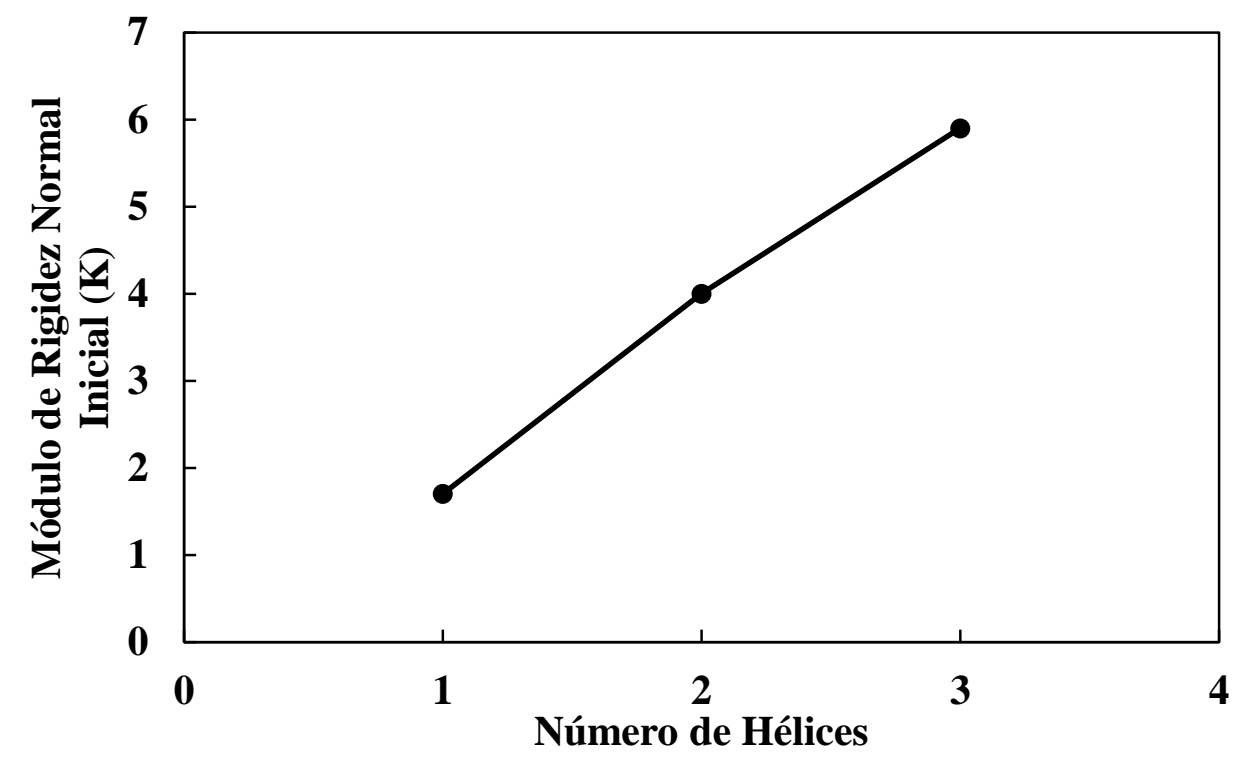

Figura 2.16: Módulo de Rigidez Normal Inicial x Número de Hélices das Estacas (modificado de CLEMENCE et al., 1994).

Este comportamento pode ser explicado pelo fato de que na prova de carga, o deslocamento medido na cabeça da estaca é soma da parcela de deformação elástica da haste e do deslocamento da hélice da ponta (todas as hélices movem-se juntamente pois estão soldadas na mesma haste, e a da ponta por estar em solo mais resistente é a que comanda o movimento). Portanto, quanto mais hélices a estaca tiver, menor será o deslocamento medido no topo da estaca, porque menor será a carga que chegará na hélice da ponta.

Segundo Ghaly e Hanna (1991) a geometria da hélice influencia muito pouco (ou nada) na resistência à tração da estaca helicoidal. Esta conclusão foi dada com base nos ensaios realizados em modelos de estacas com uma hélice instaladas em areia, com hélices de diferentes configurações (alturas e tipos de passo). 
Lutenegger (2011) também analisou o efeito do número e configuração das hélices na capacidade de carga, através de estudo de eficiência da estaca helicoidal multi-hélices. Primeiramente, foi analisada a eficiência de estacas multi-hélices com hélices iguais (estacas cilíndricas), através da verificação da eficiência de uma estaca cilíndrica de três hélices com diferentes valores de S/D conforme Figura 2.17.

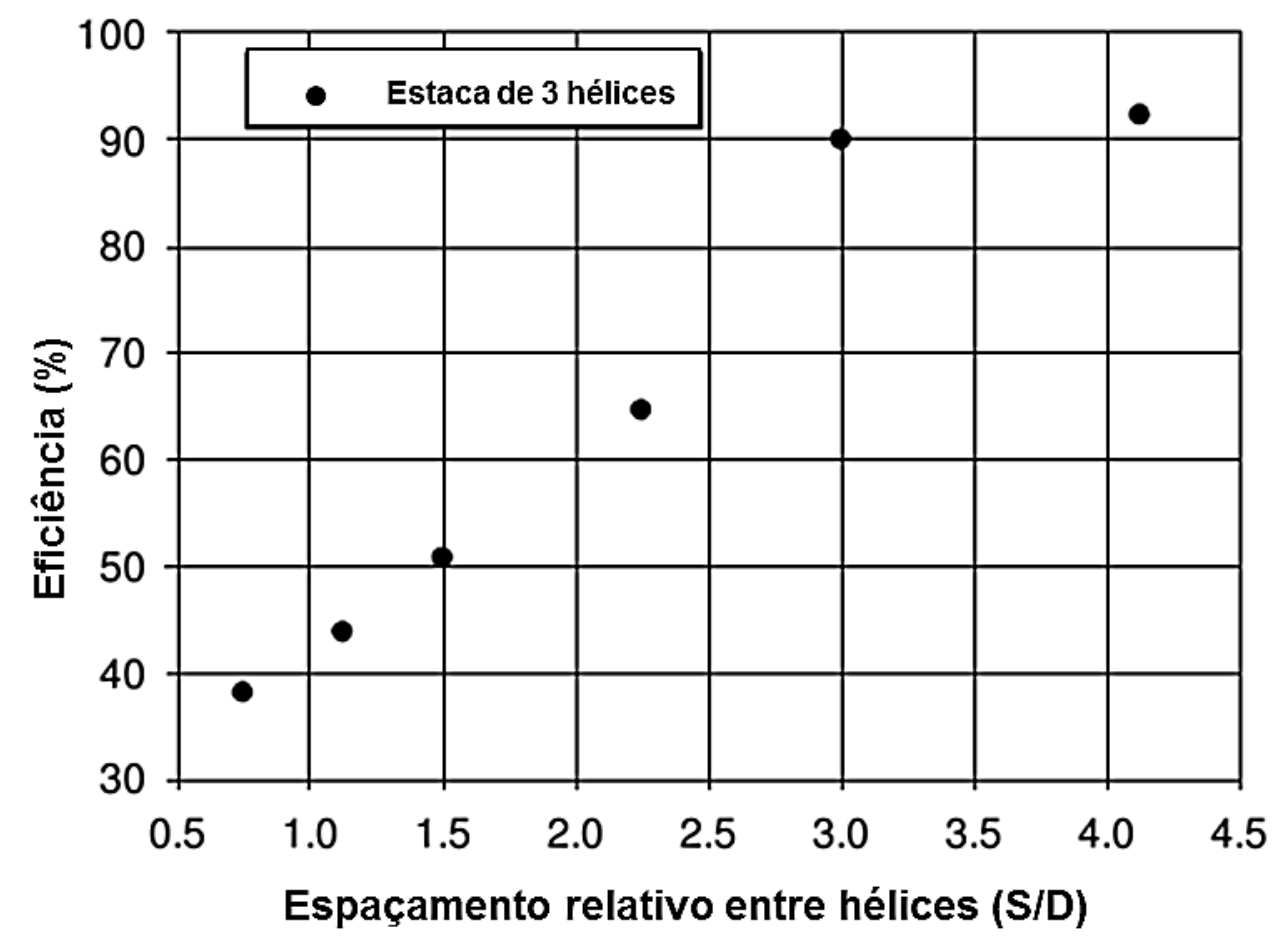

Figura 2.17: Eficiência de uma estaca cilíndrica de três hélices em função do espaçamento relativo entre hélices (S/D). (LUTENEGGER, 2011)

Os resultados da Figura 2.17 mostram que quão maior o espaçamento entre hélices, maior é a eficiência da estaca, ou seja, melhor é o efeito de ganho de capacidade de carga das hélices em relação uma estaca de uma hélices apenas. Mostram também que estacas com S/D iguais ou maiores que 3 possuem eficiência de $90 \%$ ou mais para solos arenosos. Estes resultados foram semelhantes aos encontrados por Lutenegger (2009) em ensaios realizados em solos argilosos.

E cruzando este resultado com a constatação de que S/D igual a três é o limítrofe de comportamento entre o modo de ruptura cilíndrica e capacidade de cargas individuais, chega-se a 
conclusão de que estacas com comportamento de ruptura por capacidades de cargas individuais são mais eficientes do que as cilíndricas.

Lutenegger (2011) analisa também a eficiência da estaca com o acréscimo de quantidade de hélices através da Figura 2.18. Foi plotada diferentes quantidades de hélices em espaçamentos relativos entre as hélices (S/D) constantes para averiguar a influência destas propriedades na eficiência da estaca.

Conforme Figura 2.18 mantendo-se o mesmo S/D a eficiência da estaca cai com o acréscimo das hélices. Ou seja, a eficiência da estaca diminui com o acréscimo do número de hélices, mantendo-se todas as características da estaca. Lutenegger (2011) sugere que estes resultados estão associados ao efeito da instalação. Esta redução é mais acentuada para menores S/D e menos acentuadas para estacas mais eficientes.

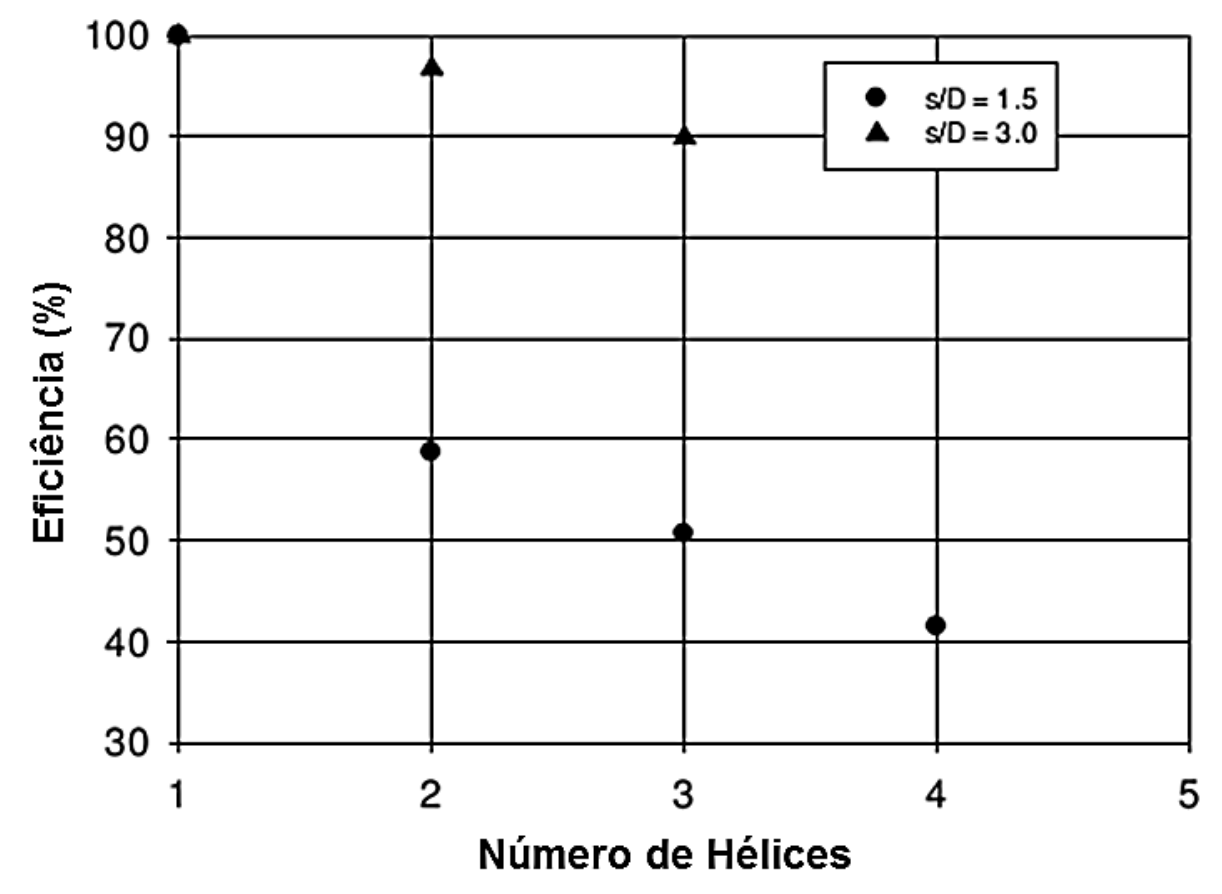

Figura 2.18: Eficiência das estacas helicoidais cilíndricas em função do número de hélices e de S/D constante. (LUTENEGGER, 2011).

É importante ressaltar que os resultados de Lutenegger (2011) na Figura 2.18 foram obtidos a partir de um único campo de ensaios e por sua vez merece mais estudos para 
confirmação do comportamento. No entanto, as conclusões obtidas são condizentes com os resultados encontrados por Sakr (2009) e por Clemence et al. (1994).

No trabalho de Lutenegger (2011) os resultados de provas de carga de duas estacas de configuração cônica de igual diâmetro médio ao da estaca de configuração cilíndrica foram comparadas, para a avaliação da influência da geometria, ou configuração, na capacidade de carga. A comparação foi realizada a partir de duas razões S/D distintas (1,5 e 3) conforme Tabela 2.4. Nesta tabela, Q5, Q10 e Q20 são os valores de capacidade de carga obtidos de curvas carga X deslocamento, obtidas em provas de carga, equivalentes aos deslocamentos de 5, 10 e $20 \%$ do diâmetro médio das hélices respectivamente.

Tabela 2.4: Resultados das capacidades de carga de estacas cônicas e cilíndrica de três hélices de mesmo diâmetro médio. (Modificado de LUTENEGGER, 2011)

\begin{tabular}{c|c|c|c|c}
$\begin{array}{c}\text { Geometria das } \\
\text { Hélices }(\mathrm{cm})\end{array}$ & $\begin{array}{c}\text { Espaçamento } \\
\text { Relativo (S/D) }\end{array}$ & $\begin{array}{c}\text { Q5 } \\
(\mathrm{kg})\end{array}$ & $\begin{array}{c}\text { Q10 } \\
(\mathrm{kg})\end{array}$ & $\begin{array}{c}\text { Q20 } \\
(\mathrm{kg})\end{array}$ \\
\hline $20 / 20 / 20$ & 1,5 & 5443 & 8165 & 9979 \\
\hline $20 / 20 / 20$ & 3,0 & 5670 & 12247 & 17690 \\
\hline $15 / 20 / 25$ & 1,5 & 3629 & 6577 & 9072 \\
\hline $15 / 20 / 25$ & 3,0 & 6804 & 11793 & 13608
\end{tabular}

Os resultados mostraram que as estacas cilíndricas (igual diâmetro) possuem maior capacidade de carga em ambos os espaçamentos S/D. No caso de S/D igual a 3, a estaca cilíndrica obteve capacidade de carga em torno de 30\% superior a estaca de configuração cônica.

As baixas capacidades de carga observadas para as estacas de configuração cônicas na Tabela 2.4 podem indicar efeitos de perturbação durante a instalação da estaca que não são tão significantes nas estacas de configuração cilíndrica. A hélice de maior diâmetro no topo das estacas de configuração cônica podem ter contribuído significativamente com a perda de capacidade de carga. É evidente que o fenômeno exposto é mais complexo do que as conclusões consideradas e como há uma falta de dados de campo nesta área, testes adicionais em outras areias seriam úteis para avaliar cabalmente este comportamento (LUTENEGGER, 2011).

Ensaios em centrífuga foram realizados e para tanto fabricadas estacas de modo que se pudesse verificar o efeito do número de hélices na capacidade de carga à tração de estacas 
metálicas helicoidais de hélices de mesmo diâmetro. Com os resultados se obteve a parcela da capacidade de carga de cada hélice em uma estaca cilíndrica de três hélices em três modelos de estacas com diâmetros variados entre $21 \mathrm{a} 44 \mathrm{~cm}$, tais resultados em carga e em percentual são apresentados na Tabela 2.5 (Tsuha et al, 2007).

Tabela 2.5: Parcelas de capacidade de carga à tração relativas às hélices das estacas com três hélices ensaiadas em centrífuga (dimensões convertidas para o protótipo). TSUHA et al (2007)

\begin{tabular}{|c|c|c|c|c|c|}
\hline Solo & $\begin{array}{c}\text { Diâmetro } \\
\text { da } \\
\text { hélice } \\
(\mathrm{mm})\end{array}$ & $\begin{array}{c}\text { Estaca } \\
\mathrm{N}^{\circ}\end{array}$ & Hélice & $\begin{array}{c}\mathrm{Q}_{\mathrm{hn}} \text { (capacidade } \\
\text { de carga } \\
\text { relatica a cada } \\
\text { hélice), } \mathrm{kN}\end{array}$ & $\begin{array}{c}\% \text { (parcela de } \\
\text { capacidade de } \\
\text { carga relatica a } \\
\text { cada hélice) }\end{array}$ \\
\hline \multirow{9}{*}{$\begin{array}{c}\text { Areia } 1 \\
(\mathrm{ID}=56 \%)\end{array}$} & 210 & \multirow{3}{*}{3} & inferior & 14 & $32 \%$ \\
\hline & & & central & 5 & $12 \%$ \\
\hline & & & superior & 24 & $56 \%$ \\
\hline & & \multirow{3}{*}{6} & inferior & 46 & $41 \%$ \\
\hline & & & central & 37 & $33 \%$ \\
\hline & & & superior & 29 & $26 \%$ \\
\hline & 440 & \multirow{3}{*}{9} & inferior & 69 & $46 \%$ \\
\hline & & & central & 39 & $26 \%$ \\
\hline & & & superior & 42 & $28 \%$ \\
\hline \multirow{9}{*}{$\begin{array}{c}\text { Areia } 2 \\
(\mathrm{ID}=85 \%)\end{array}$} & 210 & \multirow{3}{*}{3} & inferior & 60 & $52 \%$ \\
\hline & & & central & 28 & $24 \%$ \\
\hline & & & superior & 28 & $24 \%$ \\
\hline & & \multirow{3}{*}{6} & inferior & 177 & $64 \%$ \\
\hline & & & central & 57 & $21 \%$ \\
\hline & & & superior & 41 & $15 \%$ \\
\hline & 440 & \multirow{3}{*}{9} & inferior & 413 & $87 \%$ \\
\hline & & & central & 62 & $13 \%$ \\
\hline & & & superior & 0 & $0 \%$ \\
\hline
\end{tabular}

A porcentagem de capacidade de carga relativa à hélice da ponta na Tabela $2.5 \mathrm{em}$ geral aumenta com o diâmetro da hélice e com a densidade da areia. Tsuha et al (2007) comenta que este fato mostra que o efeito da instalação das hélices na modificação das propriedades iniciais da areia é maior em estacas de hélices de maior diâmetro e em solos mais compactos. 
Em Tsuha et al (2007) a maioria dos resultados de capacidade de carga e de torque de instalação aumentam com o acréscimo tanto do número quanto das dimensões das hélices. Além disto, a razão entre o deslocamento da estaca correspondente a carga última (U) e o diâmetro das estacas (D) de configuração cilíndricas ensaiadas foram maiores na areia muito compacta (mais densa) e não foi influenciada pelo número de hélices.

\subsection{INTERPRETAÇÃO DA PROVA DE CARGA}

Livneh e Naggar (2008) discute sobre os critérios de interpretação de ruptura das curvas carga $\mathrm{x}$ deslocamento de provas de carga em estacas helicoidais, e relata que historicamente os mesmos são relacionados a geometria das estacas e as tendências de formato das curvas.

A maioria dos pesquisadores de estacas helicoidais considera uma fração da dimensão característica das hélices, o deslocamento elástico ou intersecção de tangentes da curva cargadeslocamento vertical para definir um critério de ruptura. Assim, dada a geometria da estaca helicoidal, o critério de ruptura usado para descrever os deslocamentos verticais no topo da estaca helicoidal na carga última estava relacionada com o diâmetro maior helicoidal e a deformação elástica da haste da estaca. (LIVNEH e NAGGAR, 2008). Segue na Tabela 2.6 os critérios de ruptura comumente utilizados para ensaios em estacas helicoidais à tração.

Tabela 2.6: Critérios normalmente utilizados para interpretação das curvas carga e deslocamento em estacas helicoidais (modificado de ZHANG ET AL, 2005 APUD LIVNEH E NAGGAR, 2008)

\begin{tabular}{ll}
\hline AS-2159 (SSA 1995) & $\begin{array}{l}\text { 50mm em 1,5 vezes a carga última e 30mm no } \\
\text { descarregamento. 15mm na carga de serviço }\end{array}$ \\
\hline Critério de Davisson (1972) & $\frac{P . L}{A \cdot E}+\frac{D}{120}+4(\mathrm{~mm})$ \\
\hline FDOT (1999) & $\frac{P . L}{A \cdot E}+\frac{D}{30}$ para D maiores que $61 \mathrm{~cm}$ \\
\hline FHWA (Resse e O`Neill, 1988) & $5 \% \mathrm{D}$ \\
\hline ISSMFE 1985 e BS 8004 & $10 \% \mathrm{D}$ \\
\hline Zhang (1999) & $10 \% \mathrm{D}$ medio \\
\hline NBR 6122/2010 & $\frac{P . L}{A . E}+\frac{D}{30}$ \\
\hline
\end{tabular}


As estacas helicoidais tem sido utilizadas frequentemente como fundações de torres de linhas de transmissão, e para tanto, as fundações são submetidas oriundos da ação do vento. Estes esforços se tornam solicitações rápidas nas estacas, e para tanto, é recomendando o uso do ensaio rápido de prova de carga. (Figura 2.19)

Para determinação da capacidade de carga a norma brasileira NBR 12131/2006 rege os procedimentos de realização do ensaio de prova de carga. Esta norma permite carregamentos rápidos com estágios de 5 min, no mínimo, de permanência de carga. A Chance (2004) também propôs um manual técnico sobre recomendações de procedimentos do ensaio de prova de carga e os estágios de permanência de carga chegam a ser ainda menores que os preconizados pela norma brasileira supracitada.

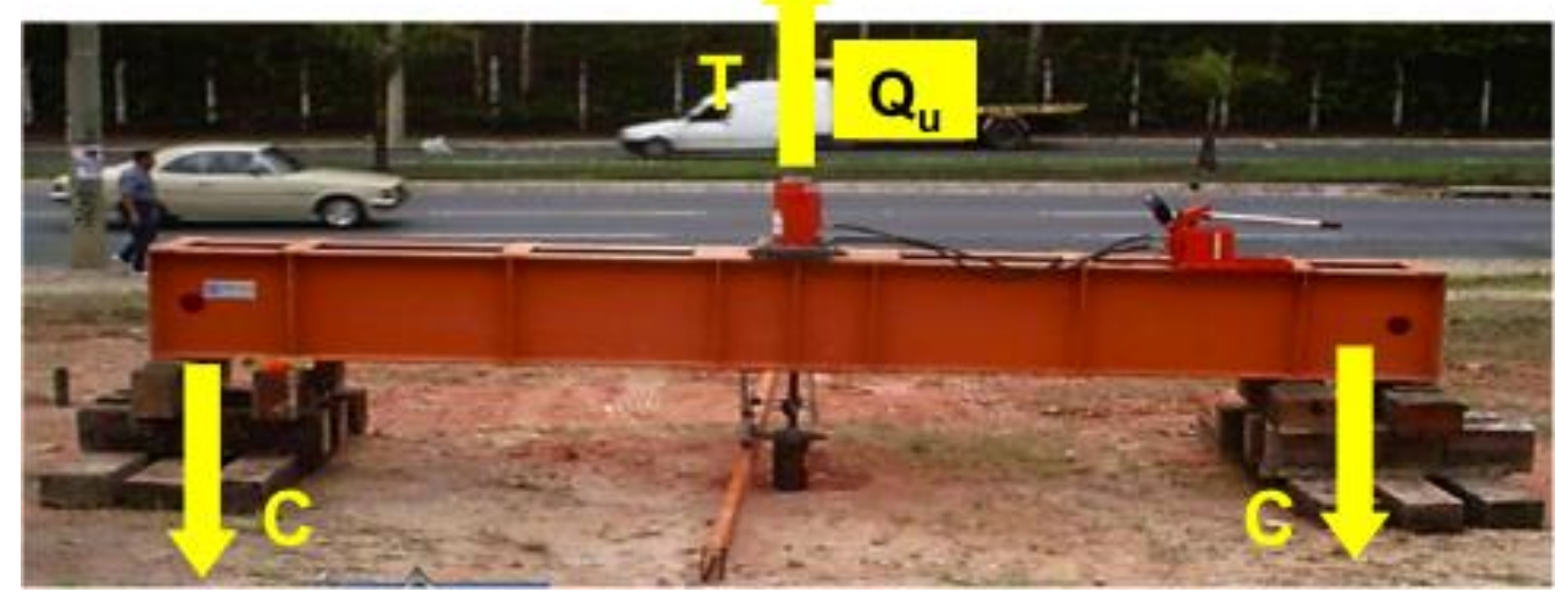

Figura 2.19: Ensaio de Prova de Carga rápida à tração em Contagem, Minas Gerais (Modificado de TSUHA, 2007). 


\section{CAPITULO 3 - MATERIAIS E MÉTODOS}

\subsection{INTRODUÇÃO}

Neste capítulo são descritos os materiais e métodos utilizados para o desenvolvimento deste trabalho.

Para analisar a influência do número e diâmetros de hélices, e da configuração destas na capacidade de carga à tração de estacas helicoidais, foram confeccionadas nove estacas com diferentes configurações. Estas são detalhadas no item 3.4 (Instalação das estacas helicoidais).

Para validar as comparações, e isolar as variáveis a serem analisadas, as estacas foram instaladas em terreno homogêneo horizontalmente, com as pontas na mesma profundidade. Todas as estacas foram fabricadas com mesmo diâmetro de haste, passo e espaçamento entre hélices. Assim, três foram as variáveis analisadas em questão: quantidade de hélices, diâmetro de hélices, e composição (hélices de mesmo diâmetro ou com diâmetros crescentes).

Para verificar a homogeneidade do terreno dos ensaios, foram realizadas investigações geotécnicas compostas por sondagens de simples reconhecimento (SPT) e ensaios de cone (CPT) na área demarcada para os experimentos. Além disso, foram retiradas as umidades gravimétricas do perfil de solo em cada metro, a partir da amostragem obtida pelo ensaio SPT.

No intuito de investigar o efeito da perturbação do solo com a instalação da estaca, e os seus efeitos na capacidade de carga à tração, foram realizados furos de CPT próximos a cada estaca metálica helicoidal. Assim, foram avaliadas também as mudanças nas propriedades do solo e a eficácia do ensaio CPT para esta finalidade.

Os valores de torque aplicado necessário para a instalação de cada estaca foram registrados a cada meio metro de profundidade penetrada através das leituras das pressões diferenciais do mandril hidráulico utilizado até o término da instalação.

A partir dos resultados dos ensaios foram comparados os valores de capacidades de carga obtidas com os métodos de cálculo, analisada a relação entre o torque de instalação e a 
capacidade de carga, e verificado o efeito da instalação e da configuração das hélices no comportamento destas estacas carregadas à tração.

\section{2 ÁREA EXPERIMENTAL}

Esta seção descreve a área experimental onde foram desenvolvidos os ensaios de campo desta dissertação. Inclui-se neste item aspectos relacionados à escolha do local dos ensaios, localização, locação das estacas ensaiadas e investigação geotécnica do terreno.

\subsubsection{ESCOLHA DO LOCAL}

Para a escolha do local dos ensaios para os experimentos desta dissertação, buscou-se as seguintes características:

- $\quad$ subsolo uniforme horizontalmente nesta área;

- resistência horizontalmente uniforme conforme o índice de penetração do SPT;

- espessura do maciço de solo maior que $10 \mathrm{~m}$ para garantir a instalação das estacas em profundidade representativa da prática;

O local escolhido está dentro da área do Centro de Recursos Hídricos e Ecologia Aplicada (CRHEA), campus associado ao Departamento de Recursos Hídricos e Engenharia Ambiental da Escolha de Engenharia de São Carlos da Universidade de São Paulo. (Figura 3.1)

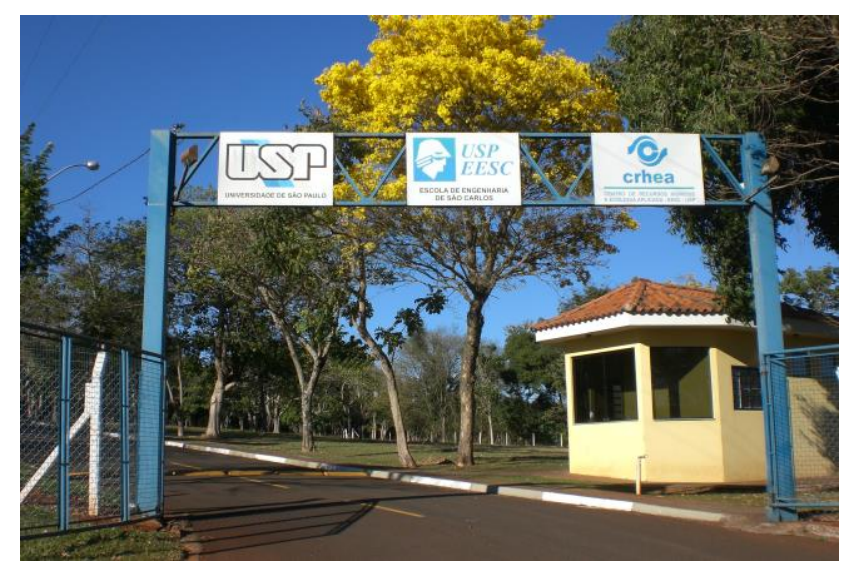

Figura 3.1: Entrada do Campus do Centro de Recursos Hídricos e Ecologia Aplicada (CRHEA) - Entrada Setor 1 


\subsubsection{LOCALIZAÇÃO}

O Centro de Recursos Hídricos e Ecologia Aplicada (CRHEA) está situado no km 13 da Rodovia Domingos Innocentini, no município de Itirapina (SP), às margens da Represa do Lobo e distante cerca de $25 \mathrm{~km}$ do Campus 1 da USP, no centro da cidade de São Carlos-SP.

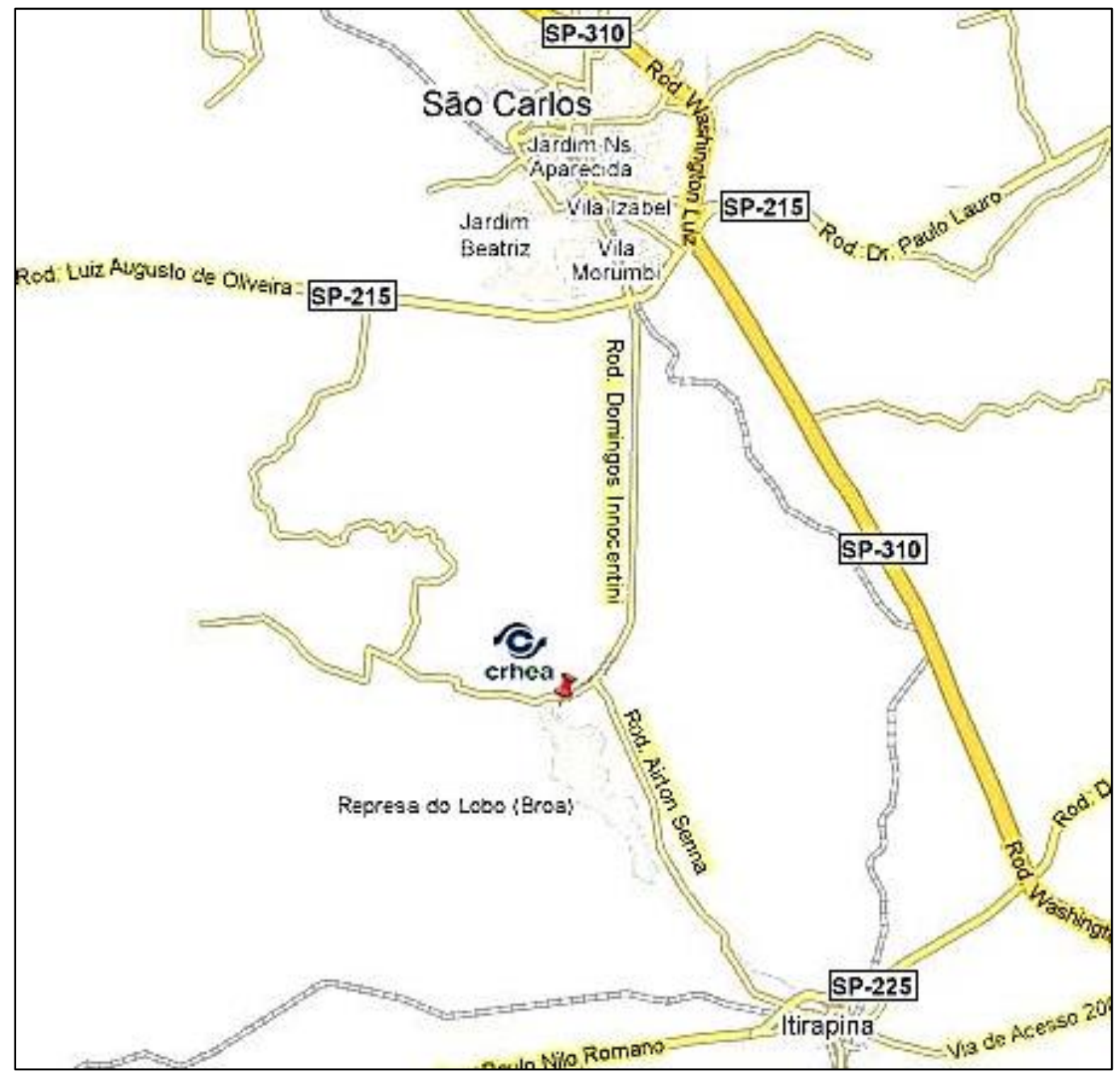

Figura 3.2: Mapa de localização do Centro de Recursos Hídricos e Ecologia Aplicada (Fonte: CRHEA LOCALIZAÇÃO, 2011)

Dentro do Campus do CRHEA, a área experimental é localizada próxima a Estação Climatológica e do poço de abastecimento de água do centro. A Figura 3.3 mostra a imagem do local, onde é possível observar as duas referências citadas.

Na Figura 3.4 pode-se observar a planta de locação dos experimentos. 


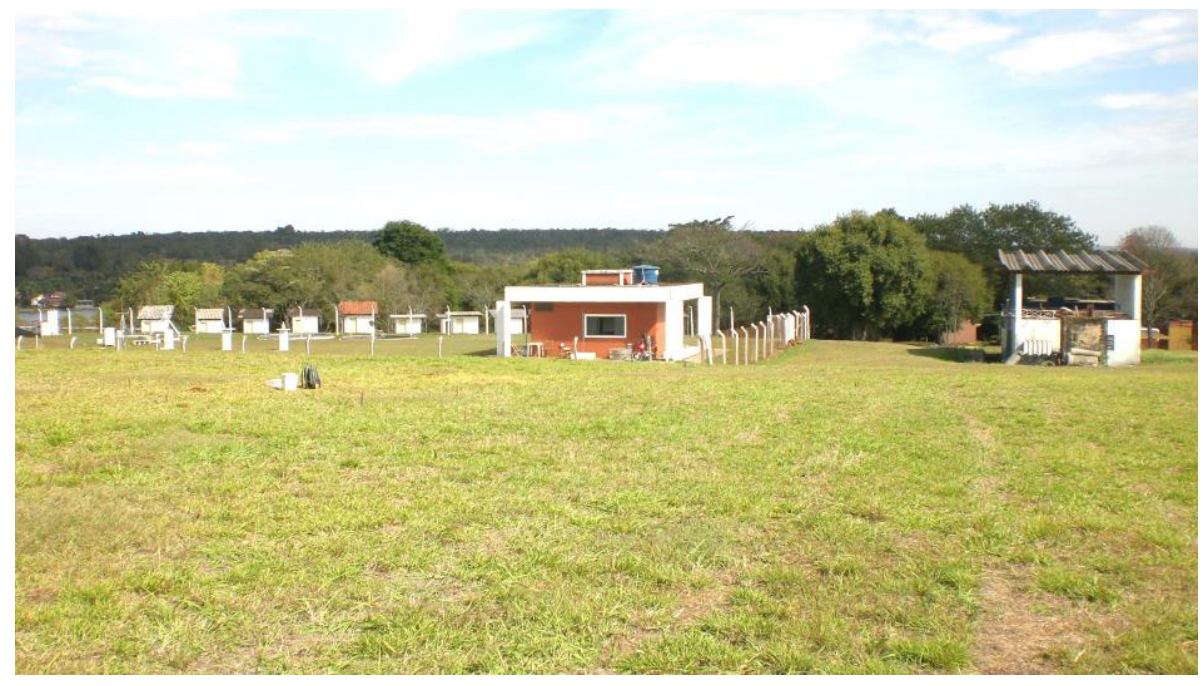

Figura 3.3: Área escolhida para os experimentos da dissertação

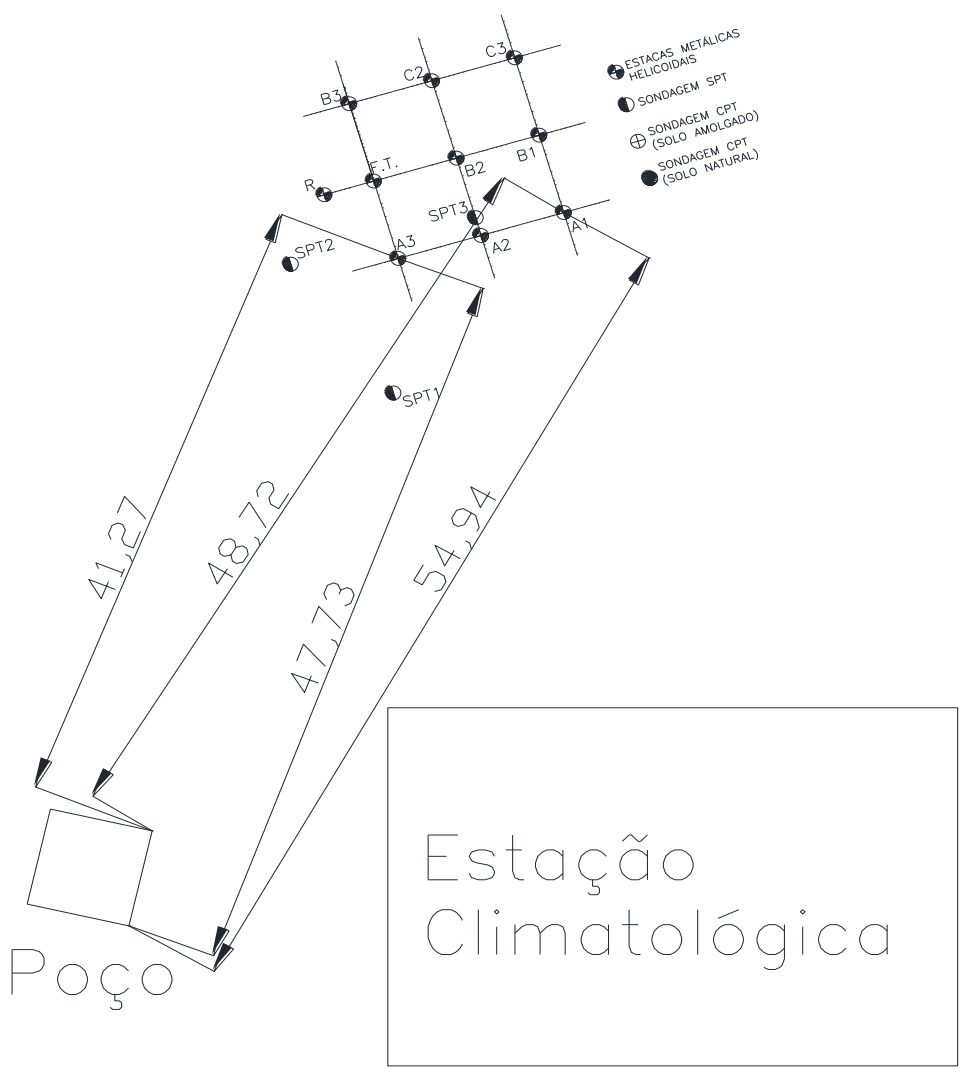

Figura 3.4: Locação da área de sondagem e estacas dentro do CRHEA (desenho fora de escala / medidas em metros). 


\subsubsection{PREPARAÇÃO DO LOCAL}

Com o estudo da locação dos furos das estacas, percebeu-se certa declividade no terreno, o que poderia dificultar tanto a campanha de sondagens e a própria instalação das estacas como também os ensaios de prova de carga. Com isso, decidiu-se cortar o terreno e deixá-lo plano. (terraplenagem - Figura 3.5). Os cortes foram em torno de 0,60m de espessura da camada superficial do solo.

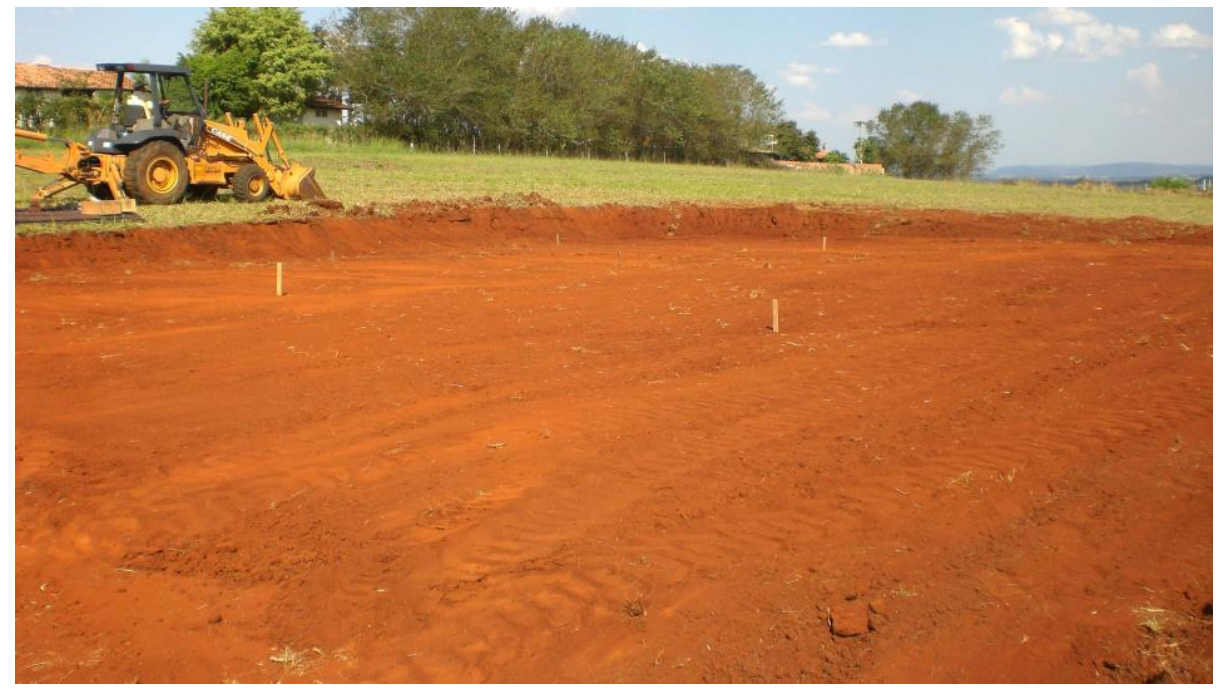

Figura 3.5: Terraplanagem do local de ensaios

Foi terraplanada uma área de $20 \mathrm{~m}$ x 20m dando espaço para a movimentação de maquinários, equipamentos e veículos. A área planeada foi suficiente para possibilitar o espaçamento mínimo entre estacas, respeitando, assim, a área de influência de cada uma.

\subsubsection{CARACTERIZAÇÃO GEOLÓGICA}

O local é caracterizado pela formação Serra Geral. Esta formação é constituída por materiais residuais originados dos basaltos, deste modo, apresentam espessuras variáveis do solo, mesmo quando desenvolvidos em condições de declividades semelhantes.

Este solo apresenta em geral baixa resistência e textura predominantemente argilosa segundo Silva (2005), porem, em alguns pontos analisados a fração silte torna-se preponderante, especialmente naqueles níveis próximos à rocha matriz. Possui coloração amarelada variegada, 
devido a presença de geotita e avermelhada variegada, devido a presença de hematita. A distribuição granulométrica característica desta formação varia da seguinte forma:

- $\quad 20$ a $50 \%$ - Silte

- $\quad 2$ a $65-$ Areia Média

- $\quad 10$ a $38 \%$ - Areia Fina

- $\quad 0$ a $1 \%$ - Areia Grossa

- $\quad 23$ a $48 \%$ - Argila

Para averiguar qual seria a distribuição granulométrica no solo em questão, foi realizado o ensaio granulométrico completo com amostra extraída na profundidade de $9 \mathrm{~m}$, em torno da profundidade das hélices das estacas da pesquisa. Segue na Figura 3.6 a curva granulométrica.

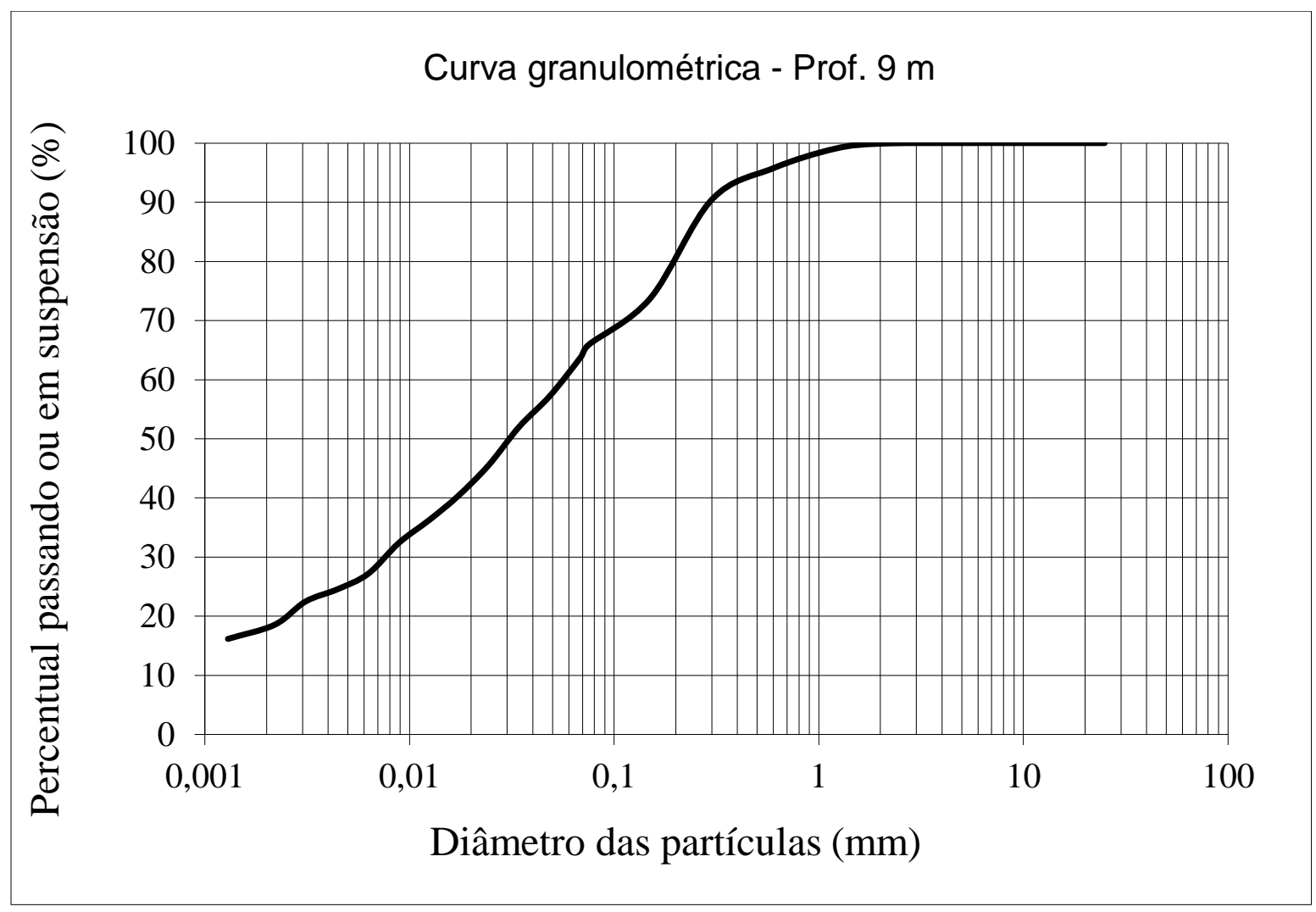

Figura 3.6: Curva granulométrica do solo do campo experimental na profundidade de $9 \mathrm{~m}$. 
Conforme a Figura 3.6 temos um solo classificado como: Silte areno-argiloso com as proporções de diâmetro médio das partículas apresentadas na Tabela 3.1

Tabela 3.1: Distribuições percentuais dos diâmetros médios das partículas obtidos com o ensaio granulométrico

\begin{tabular}{c|c} 
Silte & $43 \%$ \\
\hline Areia & $39 \%$ \\
\hline Argila & $18 \%$
\end{tabular}

\subsection{CAMPANHA DE INVESTIGAÇÃO GEOTÉCNICA}

O conjunto de ensaios desta investigação experimental é resumido nas ilustrações das Figura 3.7 e Figura 3.8:

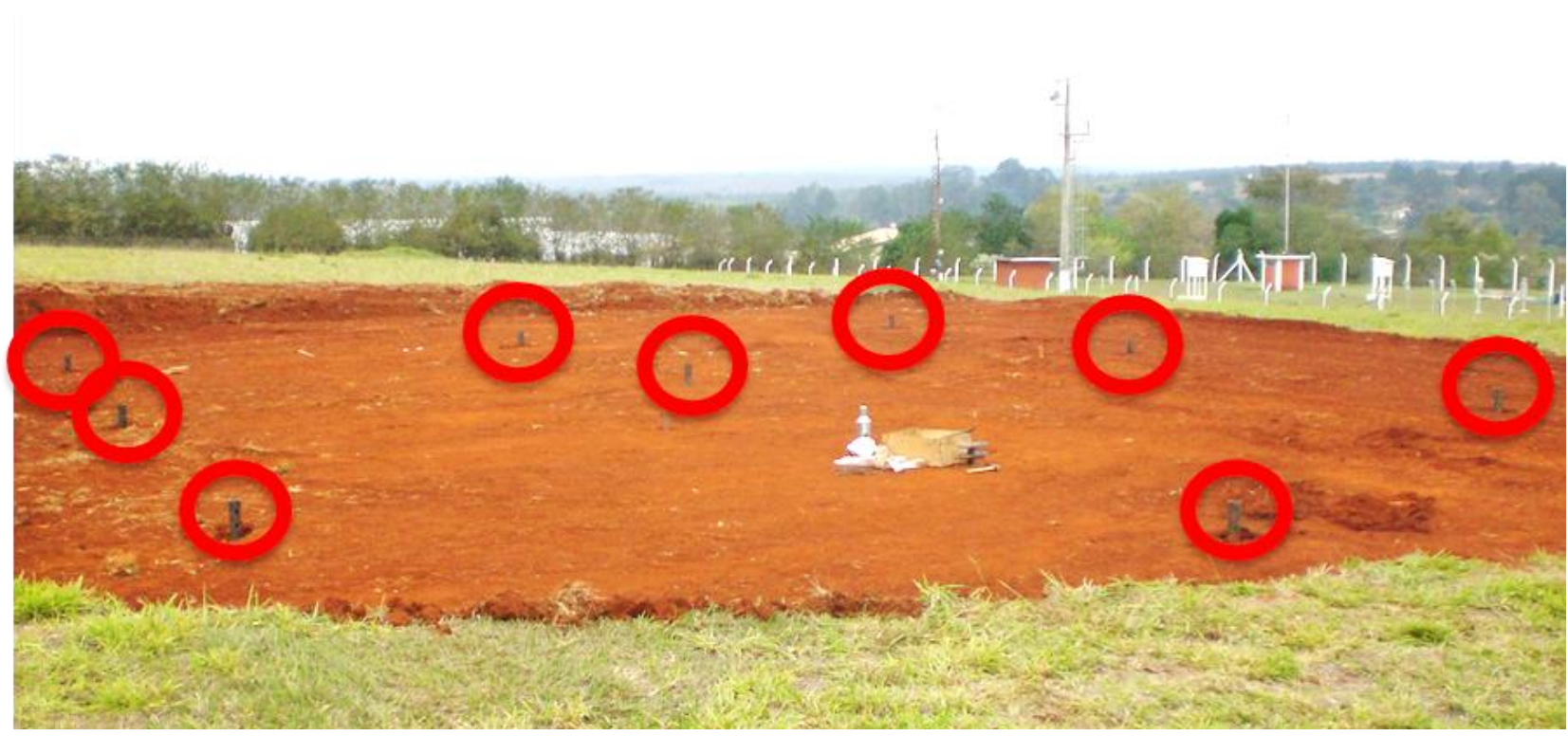

Figura 3.7: Imagem do terreno com as estacas instaladas, estacas no centro do círculo vermelho.

Os ensaios investigação geotécnica realizados para esta pesquisa foram: ensaios SPT, com retirada de amostra para ensaio de umidade gravimétrica, e ensaios CPT dentro e fora da região de influência das estacas. Maiores detalhes são descritos nas seções seguintes. 


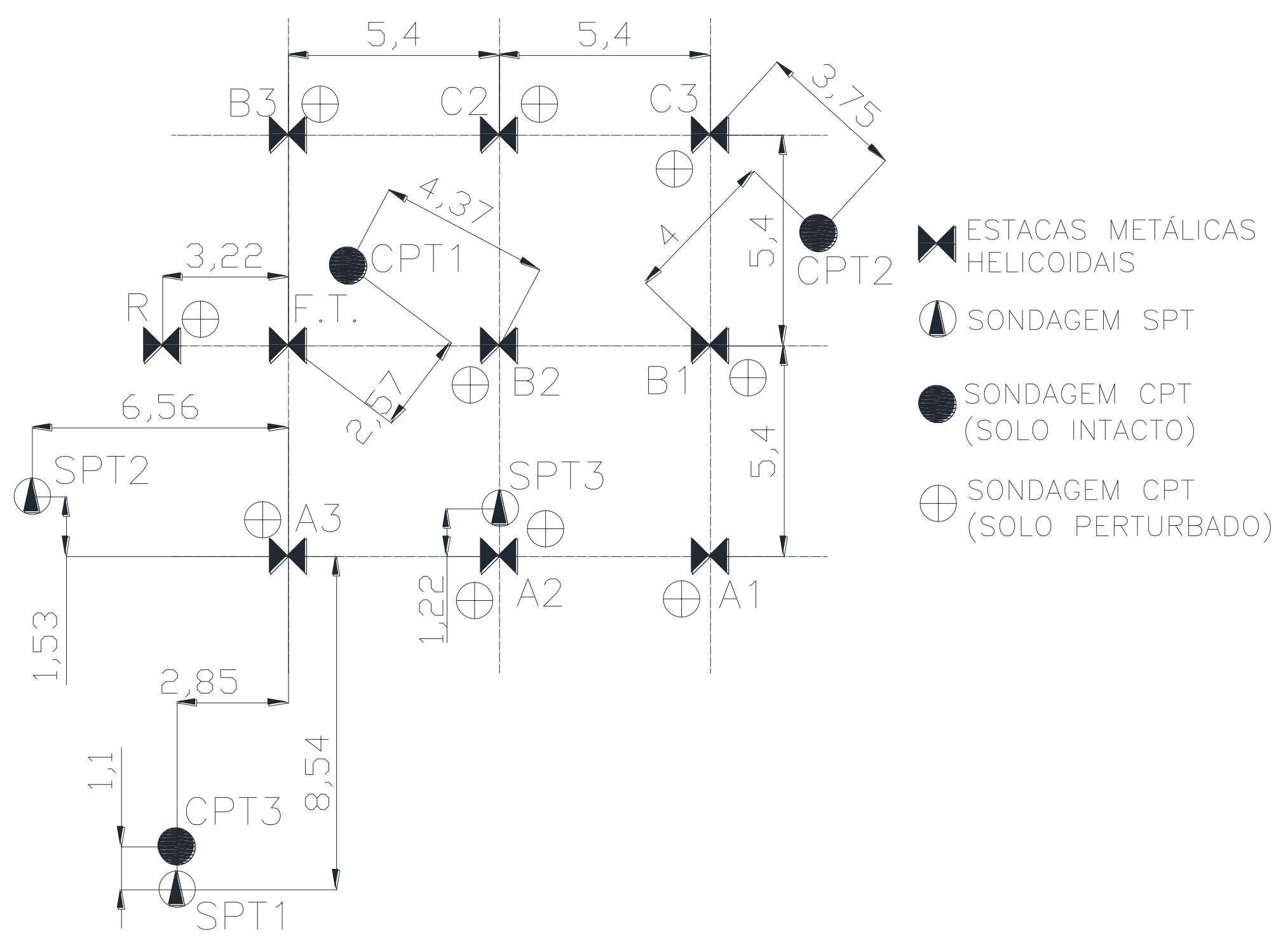

Figura 3.8: Esquema geral em planta de todos os ensaios realizados no campo experimental, medidas em metros. 


\subsubsection{ENSAIOS DE SONDAGEM DE SIMPLES RECONHECIMENTO (SPT)}

O conjunto de ensaios SPT foi realizado com o intuito de amostrar e caracterizar o campo de ensaios. Para tanto, foram feitos três furos de SPT ilustrados na Figura 3.8. Os resultados são apresentados na Figura 4.2 do CAPITULO 4 - RESULTADOS

Para garantir a uniformidade horizontal do subsolo, o teor de umidade do solo foi um parâmetro avaliado. Nos três furos do SPT as amostras obtidas com o amostrador padrão do foram imediatamente inseridas em sacos plásticos e depois lacradas e guardadas em caixa de isopor, a fim de conservar a umidade do solo. Posteriormente, a amostra foi levada ao laboratório e foram realizados ensaios de umidade gravimétrica (Figura 3.9), segundo a norma ABNT/NBR 6457/86 - Amostras de Solo - Preparação para ensaios de compactação e ensaios de caracterização.

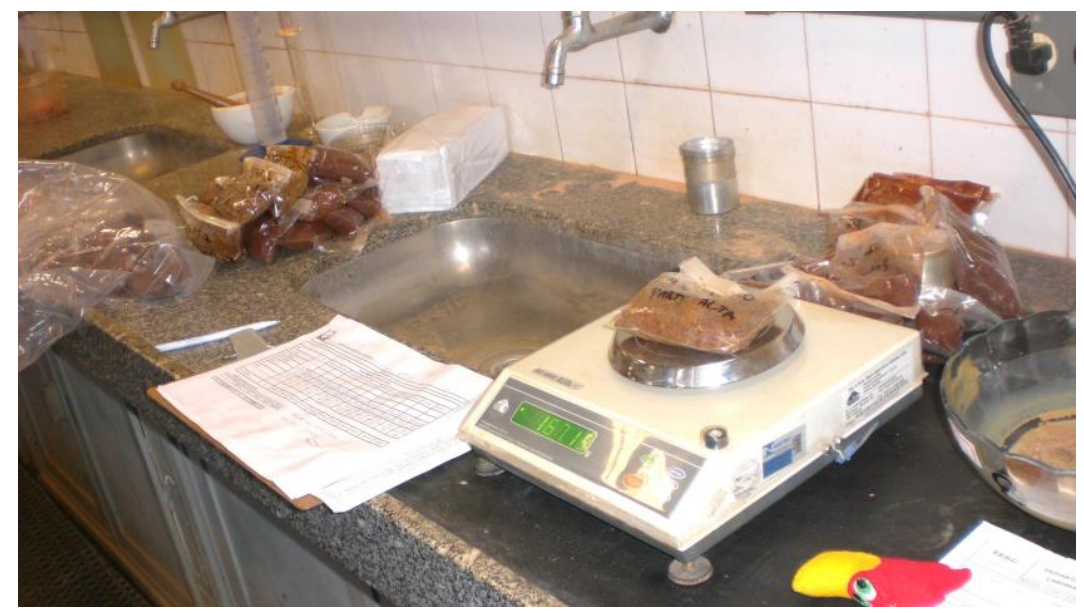

Figura 3.9: Ensaio de umidade gravimétrica das amostras do SPT

\subsubsection{ENSAIOS DE CONE - CPT}

Para os ensaios CPT foi utilizada a máquina Pagani Penetrômetro (máquina de sondagem de solo CPT) com cone elétrico. Obteve-se medição contínua de resistência à penetração, tanto resistência de ponta quanto de atrito lateral, além também de medidas de poro-pressão (Figura 3.10). No entanto, como não foi encontrado o lençol freático, a medida da pressão neutra não foi utilizada e não é apresentada neste texto. 


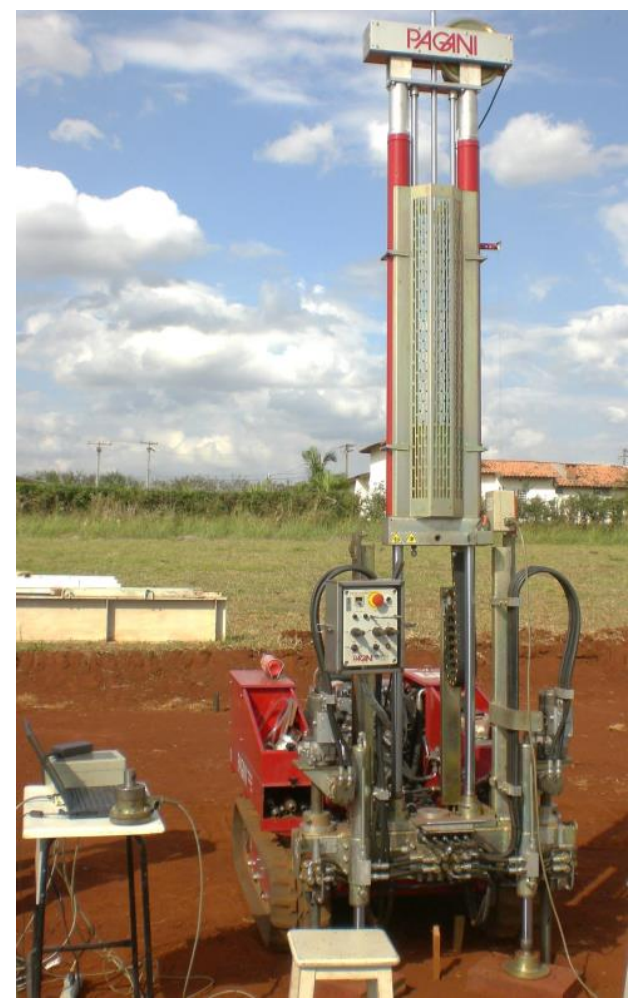

Figura 3.10: Ensaio CPT - Investigação do subsolo máquina PAGANI.

Foram realizados dois grupos de ensaios CPT com objetivos distintos. O primeiro grupo foi composto por três ensaios CPT e tiveram o objetivo de complementar a campanha de investigação geotécnica com os resultados encontrados a partir do ensaio SPT, na Figura 3.8 são representados por: "sondagem CPT (solo intacto)". O segundo grupo somou 9 ensaios CPT (um próximo de cada estaca instalada) e objetivou-se a verificação do efeito da instalação das estacas helicoidais nas propriedades geotécnicas do solo, na Figura 3.8 estão como: sondagem CPT (solo perturbado).

O primeiro grupo foi realizado anteriormente à instalação das estacas para obter as propriedades e características inicias do solo, ou seja, os valores de $q_{c}$ (resistência da ponta do cone do CPT) e $f_{\mathrm{s}}$ (resistência lateral do cone do CPT) antes de uma possível modificação do solo devido a instalação das estacas, sendo então estes primeiros testes utilizados como referências de solo intacto.

O segundo grupo buscou captar as alterações do solo penetrado pelas hélices a pósinstalação das estacas, logo, os ensaios CPT foram repetidos próximos dos cilindros de solo perturbados pela instalação das hélices das estacas. A intenção inicial era realizar os ensaios de 
cone acima da área de projeção das hélices, de modo a descer o cone por dentro do cilindro revolvido formado pela passagem das hélices. Isso não foi possível, Figura 3.15(a), devido a instalação ter desconfiando o solo ao redor das hastes, gerando um "gap" entre a haste e o solo (Figura 3.15(b)).

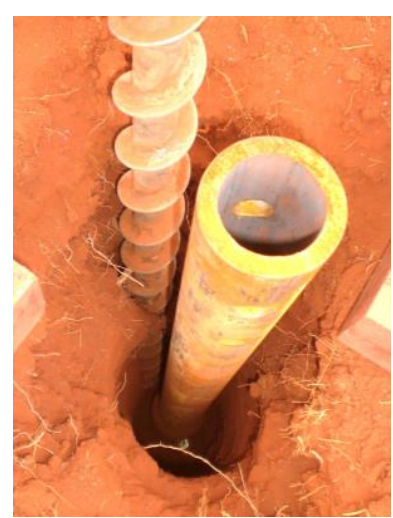

(a)

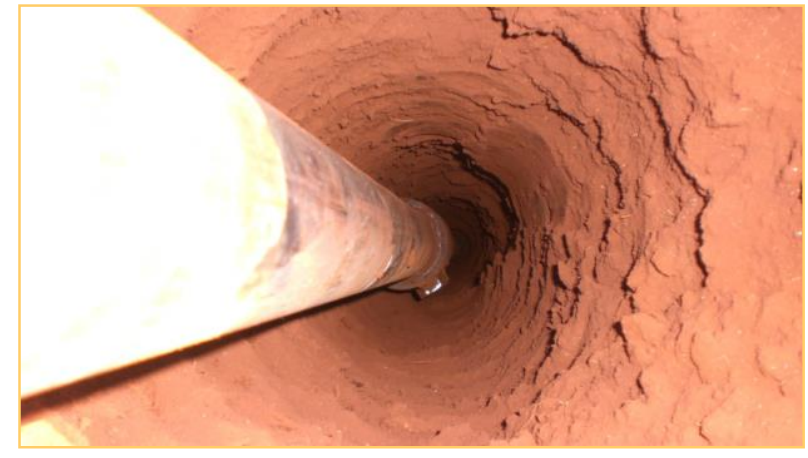

(b)

Figura 3.11: Imagens (a) da tentativa de realização do CPT acima da área projeção das hélices e (b) do "gap" gerado entre a haste e o solo.

Por fim, as distâncias realizadas entre estaca e ponteira do CPT foram entre $2 \mathrm{R}$ a $4 \mathrm{R}$ (R é o raio da hélice das estacas). Como mostra a Figura 3.12 e Figura 3.13.

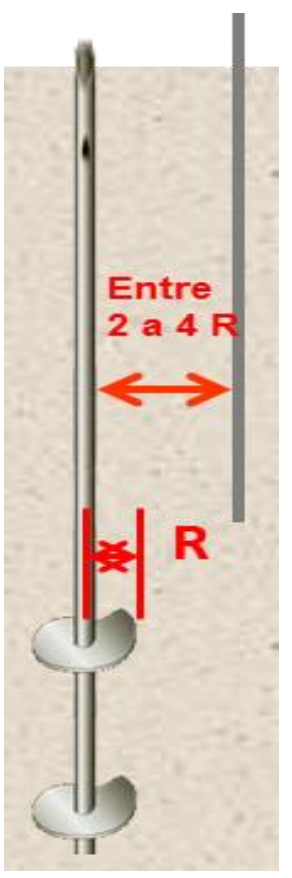

Figura 3.12 Ilustração do ensaio CPT próximos as estacas. 


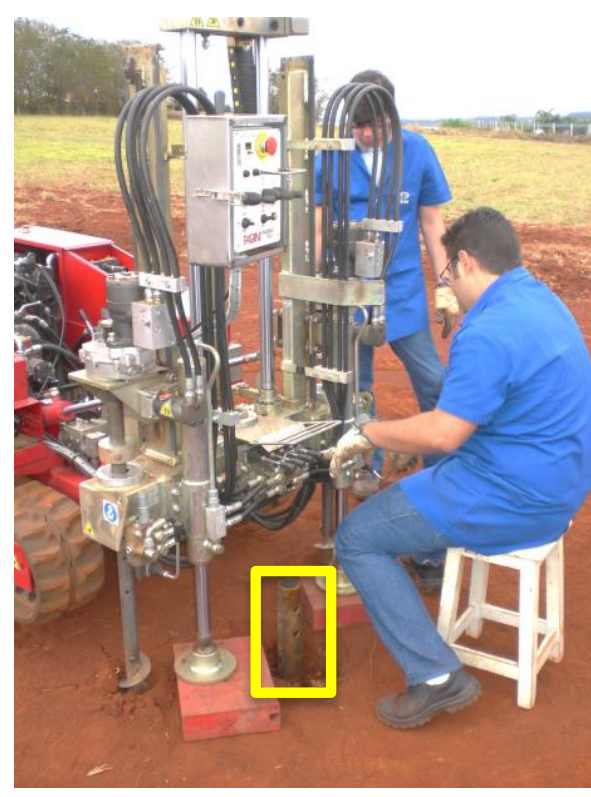

(a)

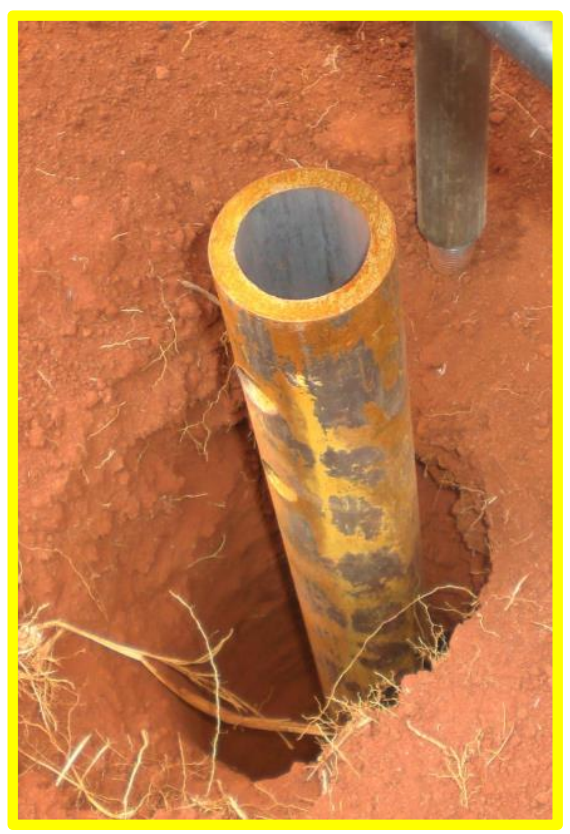

(b)

Figura 3.13: Ensaio CPT (a) próximo as estacas e (b) detalhe ampliado da haste da estaca e do cone do CPT.

\subsection{INSTALAÇÃO DAS ESTACAS ENSAIADAS}

Nesta seção são apresentados maiores detalhes das instalações das estacas, com um maior enfoque sobre as configurações das estacas, a quantidade de ensaios e a execução da instalação.

\subsubsection{CONFIGURAÇÃO DAS ESTACAS DO ENSAIO}

Foram ensaiadas nove estacas ao total, com diferentes configurações de hélices em terreno uniforme na horizontal (hipótese confirmada com os resultados dos ensaios de investigação de campo). Todas elas possuem o mesmo comprimento final de instalação, diâmetro de haste e cotas de assentamento (instaladas com a ponta da estaca em mesma profundidade). Além disso, foram confeccionadas com hélices de mesmo passo e mesmo espaçamento entre hélices, ou seja, com as estacas de mesmo número de hélices estarem com as hélices em mesma cota. Portanto, as únicas variáveis existentes são: a configuração das hélices (cônica ou cilíndrica), sua quantidade e diâmetro. O projeto das estacas pode ser visto com mais detalhes no ANEXO B. 
A convenção de símbolos utilizados é mostrada na Figura 3.14, as dimensões resumidas na Tabela 3.2, a configuração comparativa das estacas na Figura 3.15 e a distribuição esquemática das mesmas em planta na Figura 3.16.

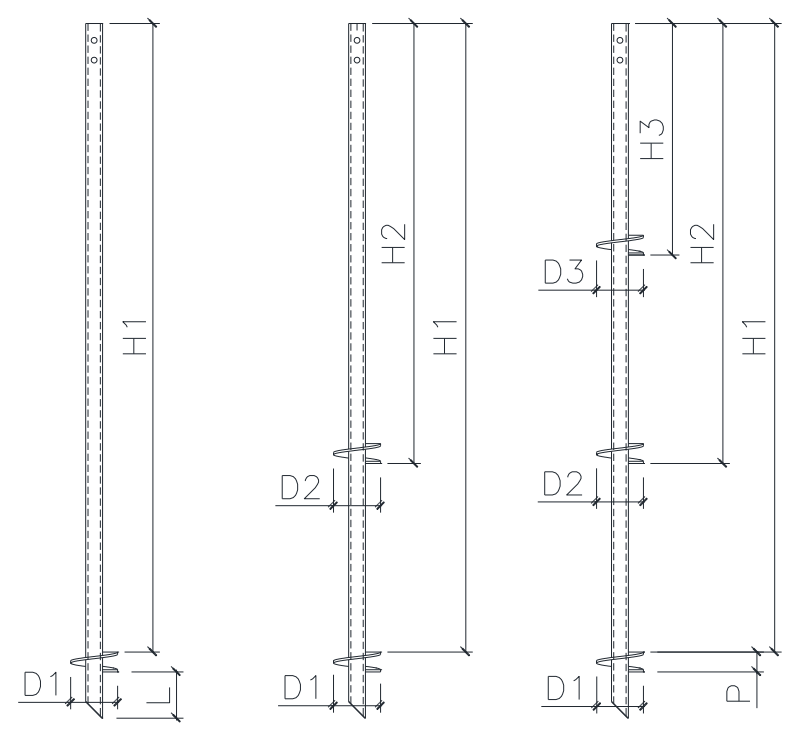

Figura 3.14: Modelos das estacas ensaiadas nesta pesquisa.

Tabela 3.2: Dimensões das estacas, medidas em milímetros.

\begin{tabular}{|c|c|c|c|c|c|c|c|c|c|}
\hline \multirow{2}{*}{ 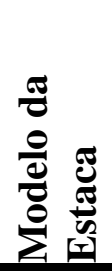 } & \multirow{2}{*}{ 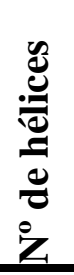 } & \multirow{2}{*}{ 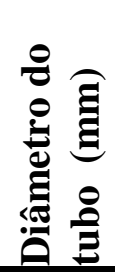 } & \multirow{2}{*}{ 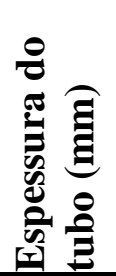 } & \multicolumn{4}{|c|}{ Propriedades das Hélices } & \multirow{2}{*}{ 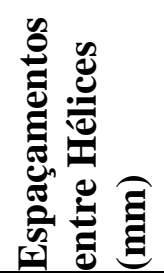 } & \multirow{2}{*}{ 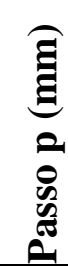 } \\
\hline & & & & $\begin{array}{c}\text { D1 } \\
(\mathbf{m m})\end{array}$ & $\begin{array}{c}\text { D2 } \\
(\mathbf{m m})\end{array}$ & $\begin{array}{c}\text { D3 } \\
(\mathbf{m m})\end{array}$ & $\begin{array}{c}\mathrm{e} \\
(\mathbf{m m})\end{array}$ & & \\
\hline $\mathrm{R}$ & - & 73 & 9,80 & - & - & - & - & - & - \\
\hline A1 & 1 & 73 & 9,80 & 203,2 & - & - & 12,7 & - & 75 \\
\hline $\mathrm{A} 2$ & 2 & 73 & 9,80 & 203,2 & 203,2 & - & 12,7 & 900 & 75 \\
\hline A3 & 3 & 73 & 9,80 & 203,2 & 203,2 & 203,2 & 12,7 & 900 & 75 \\
\hline B1 & 1 & 73 & 9,80 & 152,4 & - & - & 12,7 & - & 75 \\
\hline $\mathrm{B} 2$ & 2 & 73 & 9,80 & 152,4 & 203,2 & - & 12,7 & 900 & 75 \\
\hline B3 & 3 & 73 & 9,80 & 152,4 & 203,2 & 254 & 12,7 & 900 & 75 \\
\hline $\mathrm{C} 2$ & 2 & 73 & 9,80 & 203,2 & 254 & - & 12,7 & 900 & 75 \\
\hline C3 & 3 & 73 & 9,80 & 203,2 & 254 & 304,8 & 12,7 & 900 & 75 \\
\hline
\end{tabular}




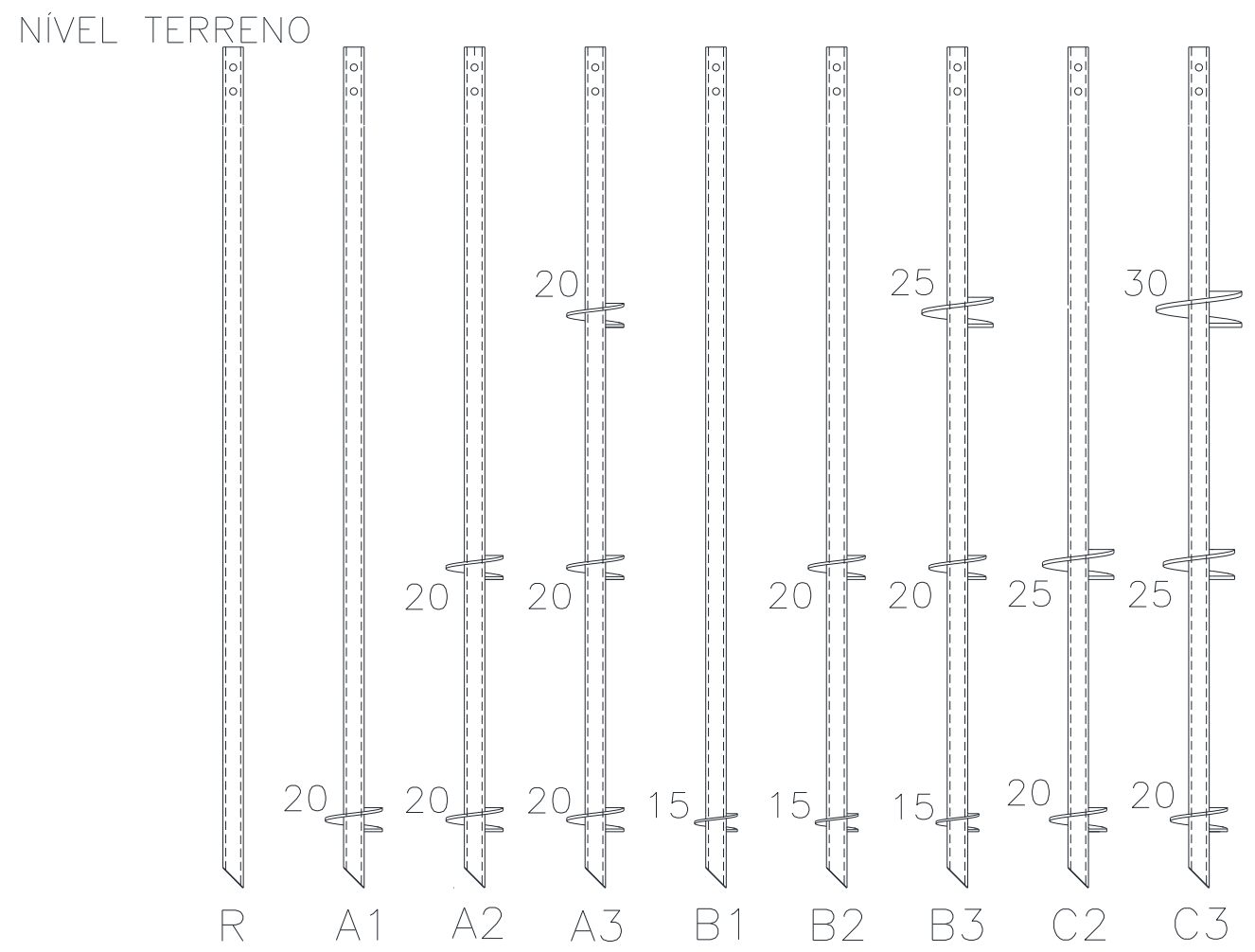

Figura 3.15: Identificação das estacas ensaiadas (diâmetros das hélices em centímetros).

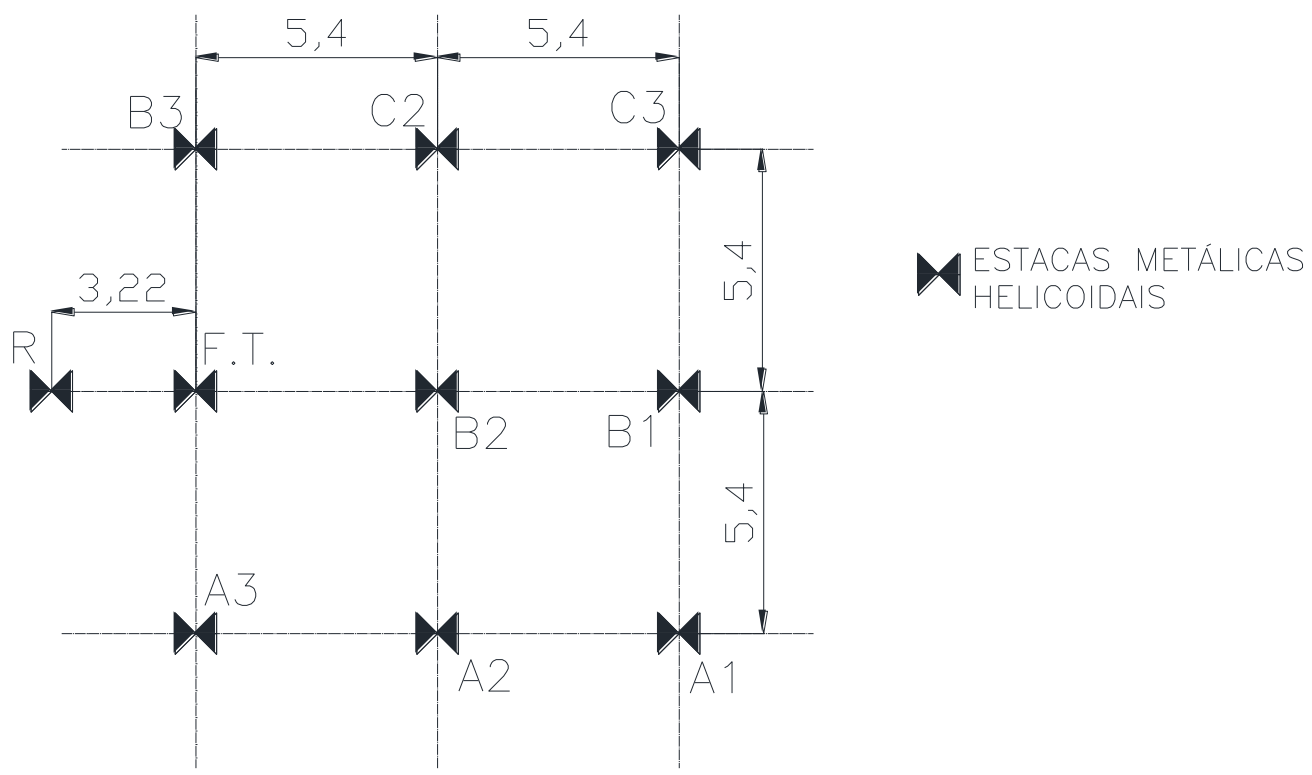

Figura 3.16: Distribuição esquemática em planta da locação das estacas metálicas helicoidais no campo experimental, medidas em metros. 
Conforme pode ser visto na Figura 3.15 de uma forma geral as estacas foram fabricadas com multi-hélices de hélices com diâmetros iguais (estacas modelo A) e com diâmetros crescentes (estacas modelos B e C). As estacas iniciadas com mesma letra possuem hélices com mesmo diâmetro considerando a mesma cota de instalação, variando apenas o número de hélices em cada estaca. A quantidade de hélices por estaca é indicada pelo número índice que aparece posterior a letra, ou seja, como exemplo o número A2 significa que a estaca é do modelo A (com diâmetros iguais de $20 \mathrm{~cm}$ ) e possui duas hélices na haste principal (o número 2 após a letra A).

Há dois casos especiais, o furo teste (F.T.) e a estaca R. Percebe-se na Figura 3.16 a legenda F.T. que significa Furo Teste, onde foi realizada a instalação da estaca B1 e posterior retirada da mesma. Também é apresentada na Figura 3.15 e na Tabela 3.2 uma estaca que não possui hélices (estaca R), ou seja, é apenas um fuste metálico na mesma especificação das demais estacas com hélices, no entanto, sem haver sido soldada nenhuma hélice a este fuste.

\subsubsection{EXECUÇÃO DA INSTALAÇÃO}

A instalação da estaca foi feita através da alteração de um braço de máquina escavadeira hidráulica (retroescavadeira) por um mandril hidráulico, Figura 3.19(c), este mandril é ligado às mangueiras da retroescavadeira e assim o próprio operador da máquina comanda as operações no mandril. (Figura 3.17)

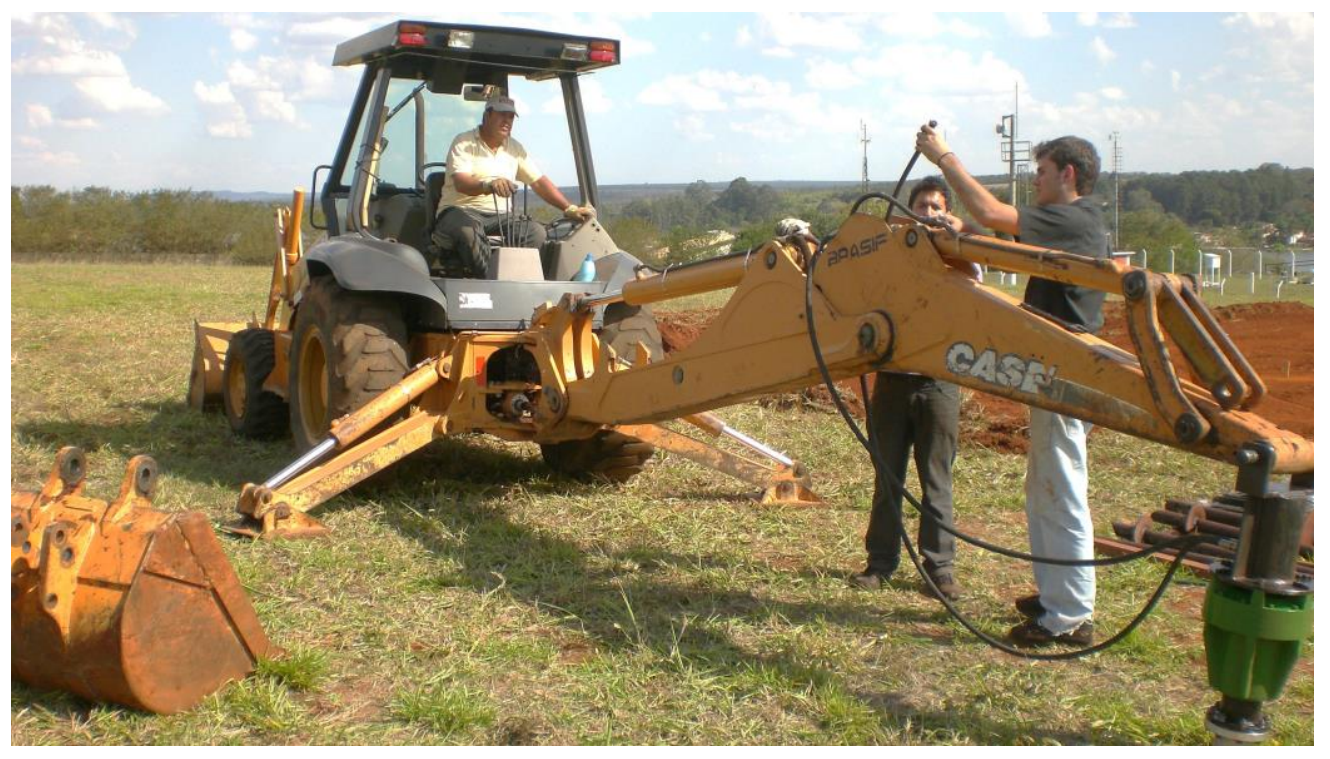

Figura 3.17: Retirada do braço da retroescavadeira e colocação do mandril hidráulico 
A potência e rotação do motor da máquina foram ajustados para que proporcionasse a instalação com velocidade de rotação média no mandril de $22 \mathrm{rpm}$. A faixa de variação recomendada por Perko (2009) é entre 5 e $25 \mathrm{rpm}$.

A estaca instalada foi marcada com giz a cada $0,50 \mathrm{~m}$ para que fosse anotada a variação da pressão diferencial durante a instalação (Figura 3.18a e b). A pressão registrada pode ser convertida em torque através da calibração do mandril (APÊNDICE A - Calibração dos Equipamentos), assim, foram registradas 20 valores de pressões diferenciais por estaca instalada.

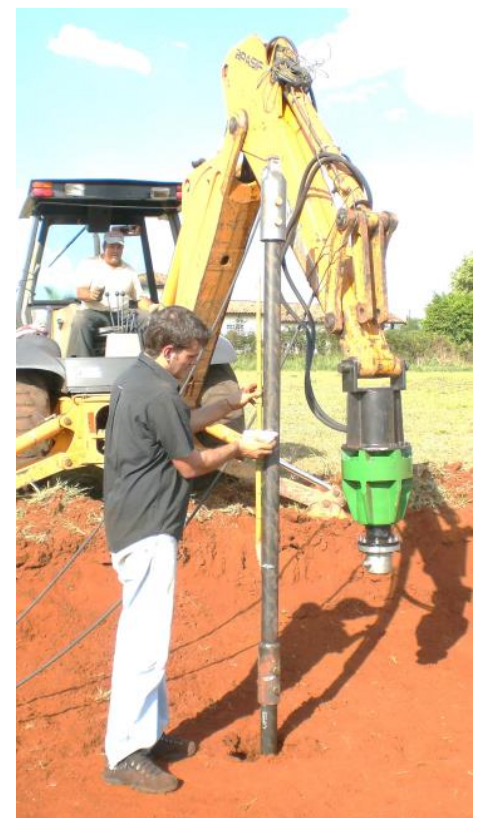

(a)

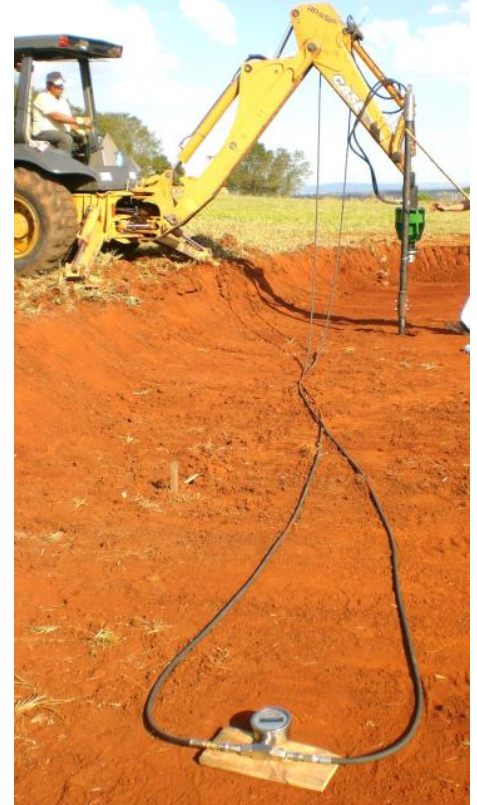

(b)

Figura 3.18: Imagens de (a) marcação de pontos de leitura a cada meio metro e (b) leitura do medidor de pressão diferencial

Para a transmissão do torque do mandril hidráulico para a haste metálica da estaca helicoidal foi necessário fabricar uma peça acopladora de aço e rígida para maior eficiência das pressões da máquina, esta peça é ligada a haste através de parafusos que também foram dimensionados para os níveis de torque e tração do ensaio. (Figura 3.19a)

O medidor de pressão diferencial para obter indiretamente os valores de torques de instalação, e o mandril utilizado para a aplicação do torque estão nas Figura 3.19b e Figura 3.19c respectivamente. 


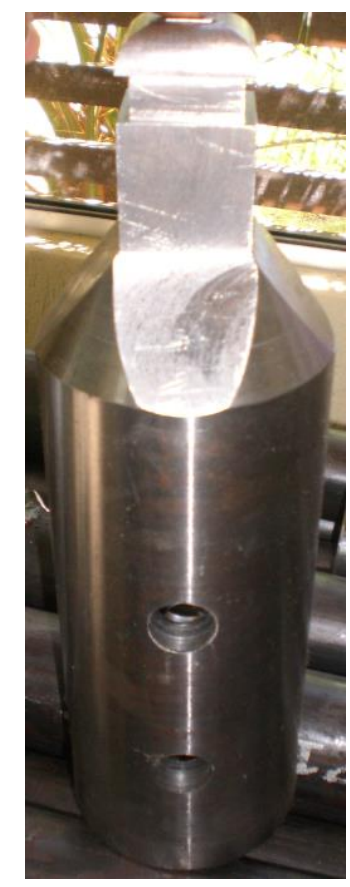

(a)

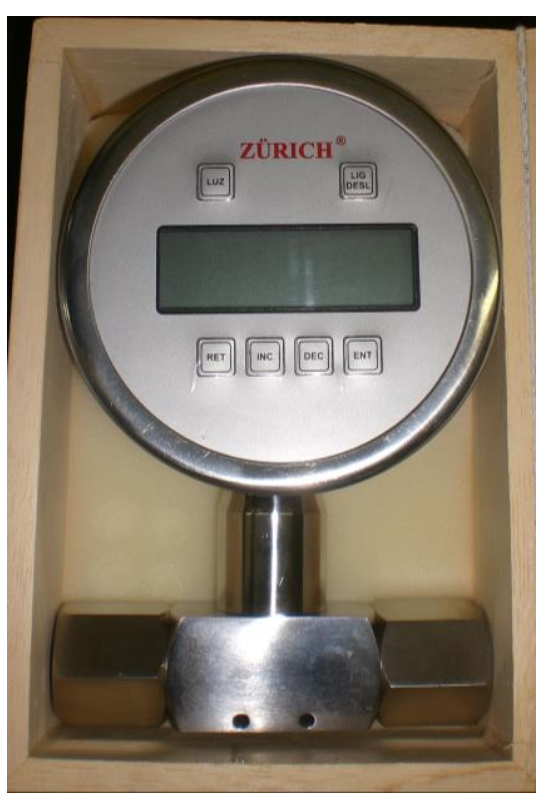

(b)

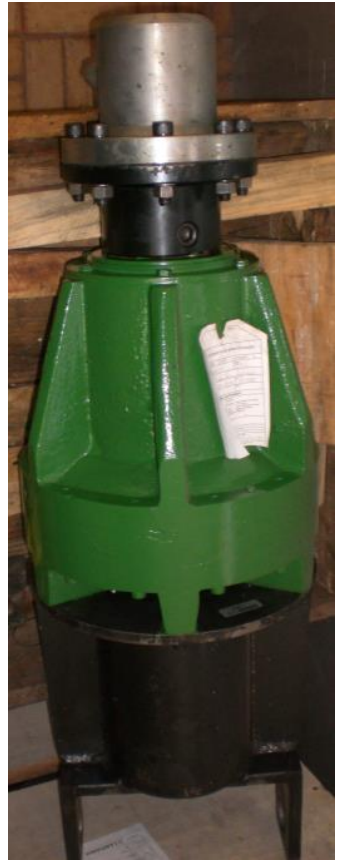

(c)

Figura 3.19: Equipamentos fornecidos para a instalação: (a) Cabeçote de aço de ligação estaca-mandril, (b) Medidor de pressão diferencial e (c) Mandril Hidráulico.

\subsection{PROVAS DE CARGA À TRAÇÃO}

Apresentam-se neste item os métodos e equipamentos utilizados nas provas de cargas a tração.

\subsubsection{EQUIPAMENTOS E MATERIAIS UTILIZADOS}

Os equipamentos utilizados para a prova de carga seguem as prescrições citadas na Norma brasileira NBR 12131/2006: Estacas - Prova de Carga Estática.

Para medição das cargas esta norma exige controle de carga por célula de carga (Figura 3.20b) ou por registro de pressões através das leituras do manômetro em bombas hidráulicas (Figura 3.20e). Por segurança e checagem dos registros, foram utilizados os dois tipos de leituras. 
Para aplicação das cargas é preciso um conjunto macaco/cilindro hidráulico (Figura 3.20c) e bomba elétrica ou hidromecânica (Figura 3.20e) e 4 relógios comparadores mecânicos (deflectômetros, Figura 3.20d).

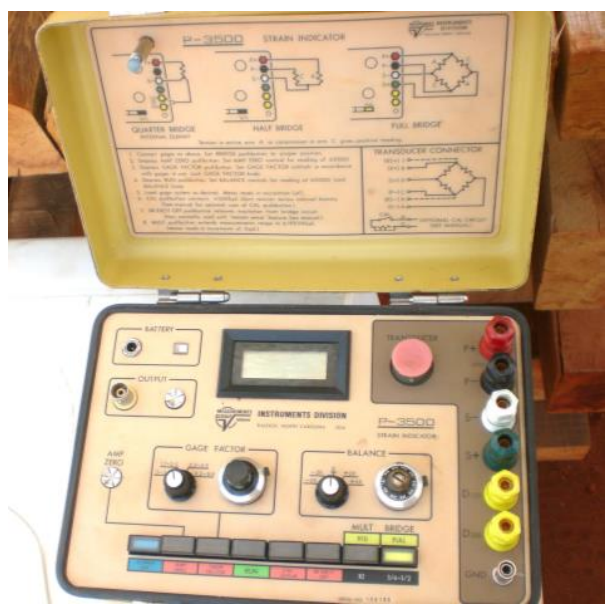

(a)

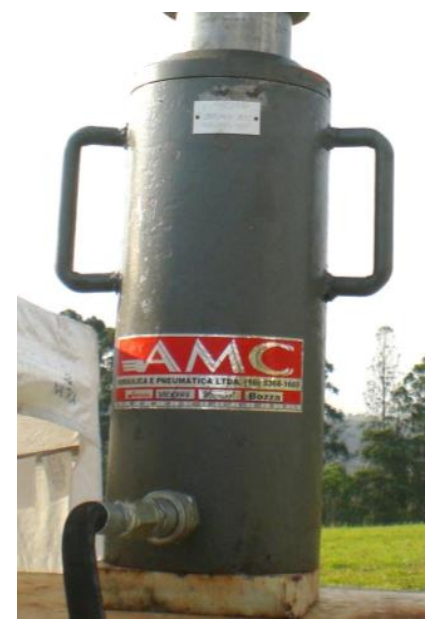

(c)

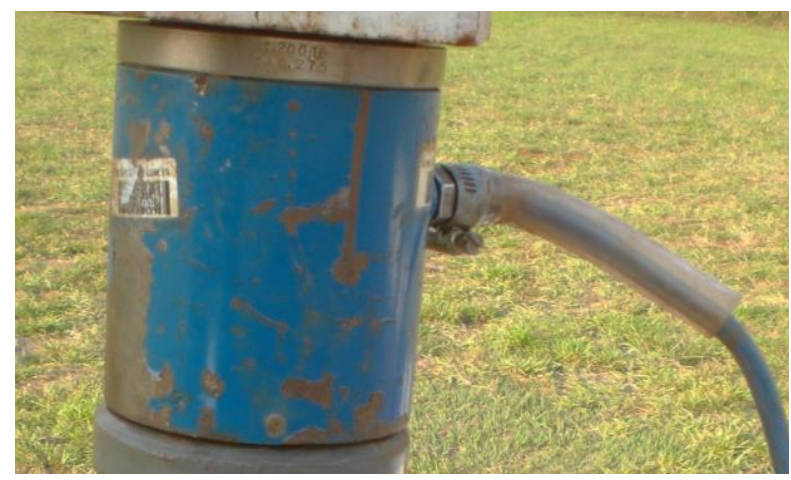

(b)

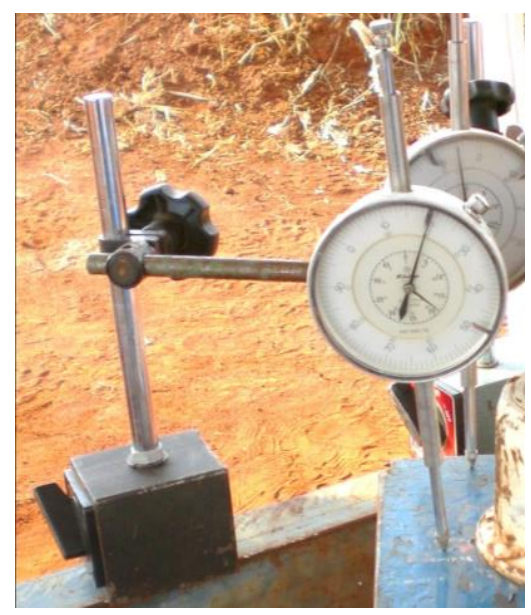

(d)

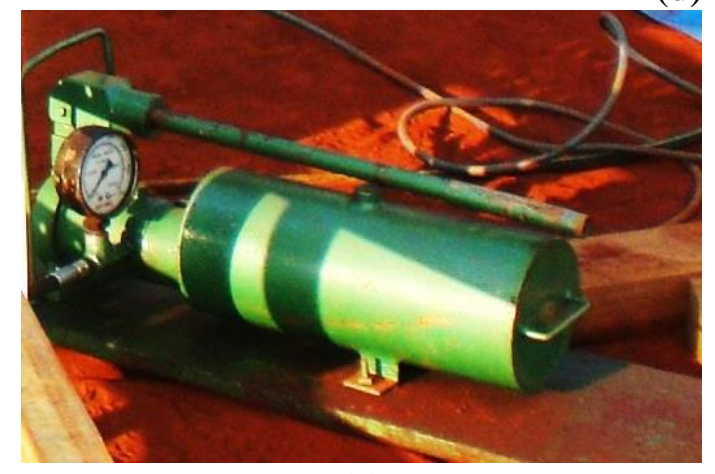

(e)

Figura 3.20: Equipamentos utilizados na prova de carga: (a) aquisição da célula de carga, (b) célula de carga, (c) cilindro hidráulico vazado, (d) relógio comparador, (e) bomba hidráulica. 


\subsubsection{SISTEMA DE REAÇÃO}

A montagem do ensaio com as especificações das distâncias, materiais e métodos atende à norma Brasileira NBR 12131/2006 e as recomendações da ASTM D 3689-07. O sistema de reação com suas medidas e cada um de seus elementos é exposto na

Figura 3.21 e na Figura 3.22.

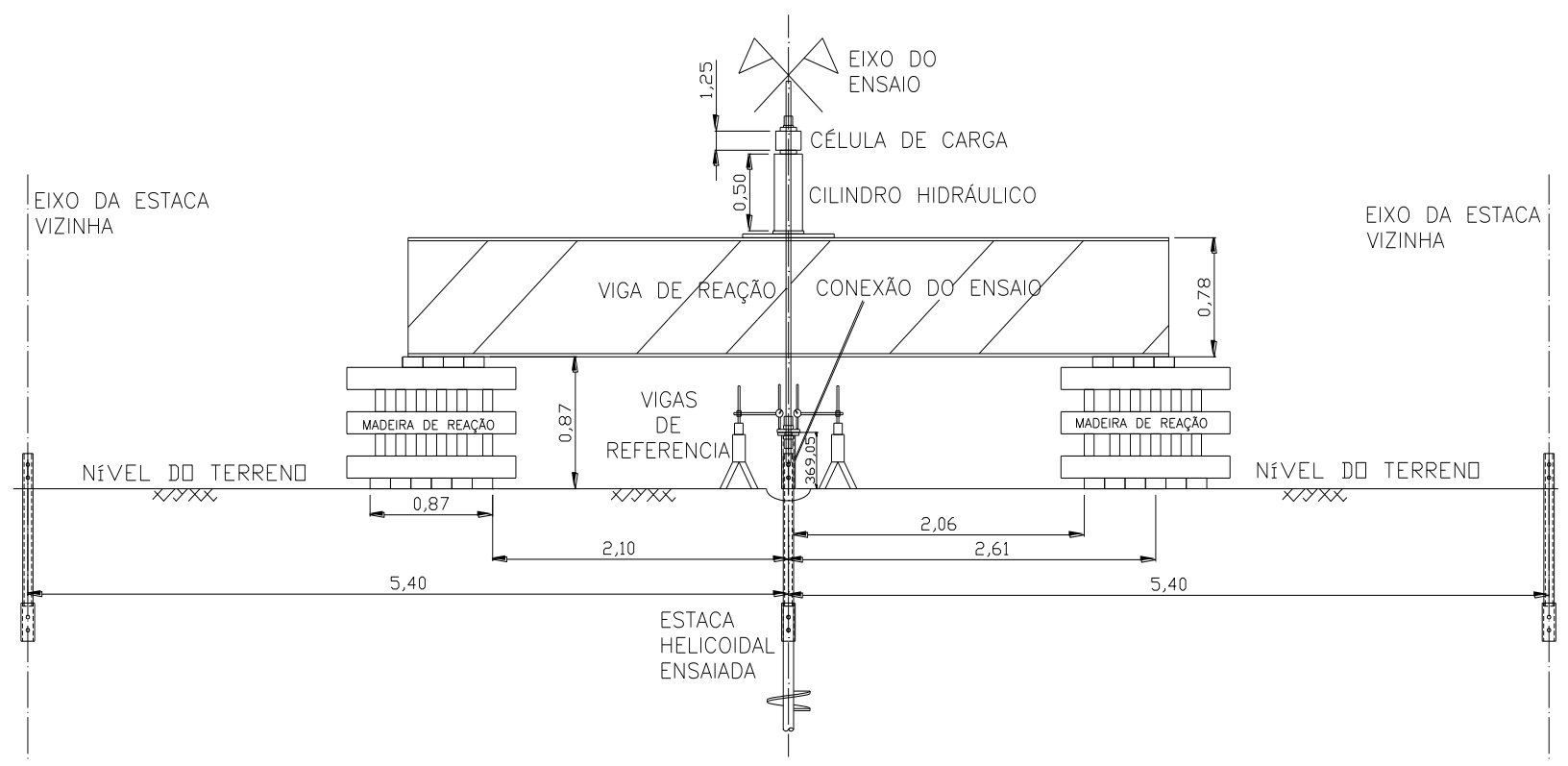

Figura 3.21: Ilustração da fachada do sistema de reação, medidas em metros.

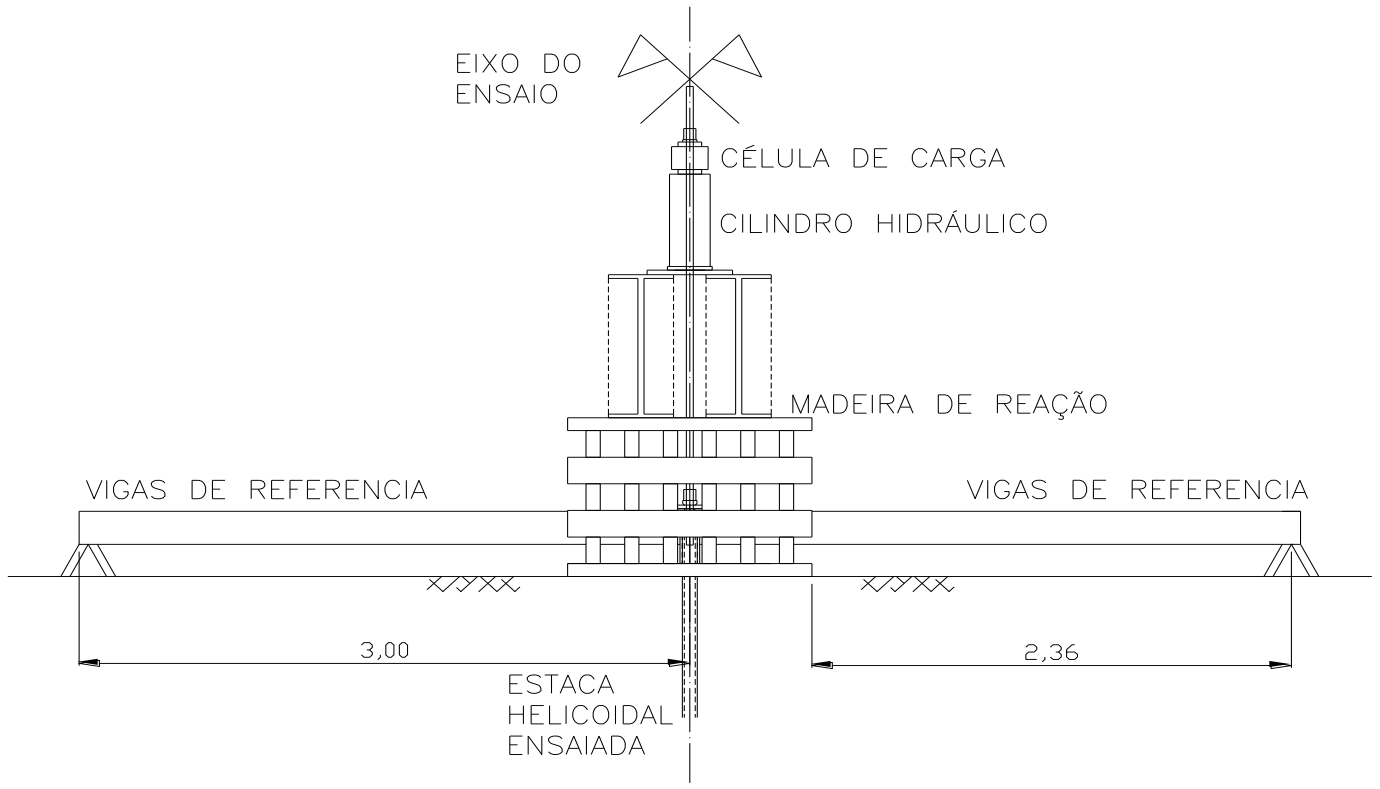

Figura 3.22: Ilustração da vista do sistema de reação, medidas em metros. 
O sistema de aplicação de carga e reação funciona da seguinte maneira:

- É aplicada pressão no macaco hidráulico (Figura 3.20c) através da bomba hidráulica (Figura 3.20e).

- A pressão que chega ao macaco expande seu êmbolo/pistão que sobe verticalmente e aplica carga na célula de carga (Figura 3.20a) e na barra de protensão.

- A barra de protensão é tracionada pelo macaco e transmite esta carga a peça (Figura 3.24a) ligada a estaca.

- Por sua vez, a peça que está aparafusada a estaca é tracionada e traciona a estaca.

- E assim, continuadamente cada acréscimo de pressão aplicada pela bomba vai sendo transmitida a estaca por estas etapas e equipamentos.

Neste esquema de ensaio de prova de carga à tração o macaco (cilindro hidráulico) ficou acima da viga de reação (ver Figura 3.22), gerando nas reações (madeiras de reação) cargas de compressão. Logo, foi escolhido o uso de reações em forma de fogueira de madeira (Figura 3.23), devido à praticidade e rapidez de montagem, além da possibilidade de reuso, o que barateou os custos dos ensaios.

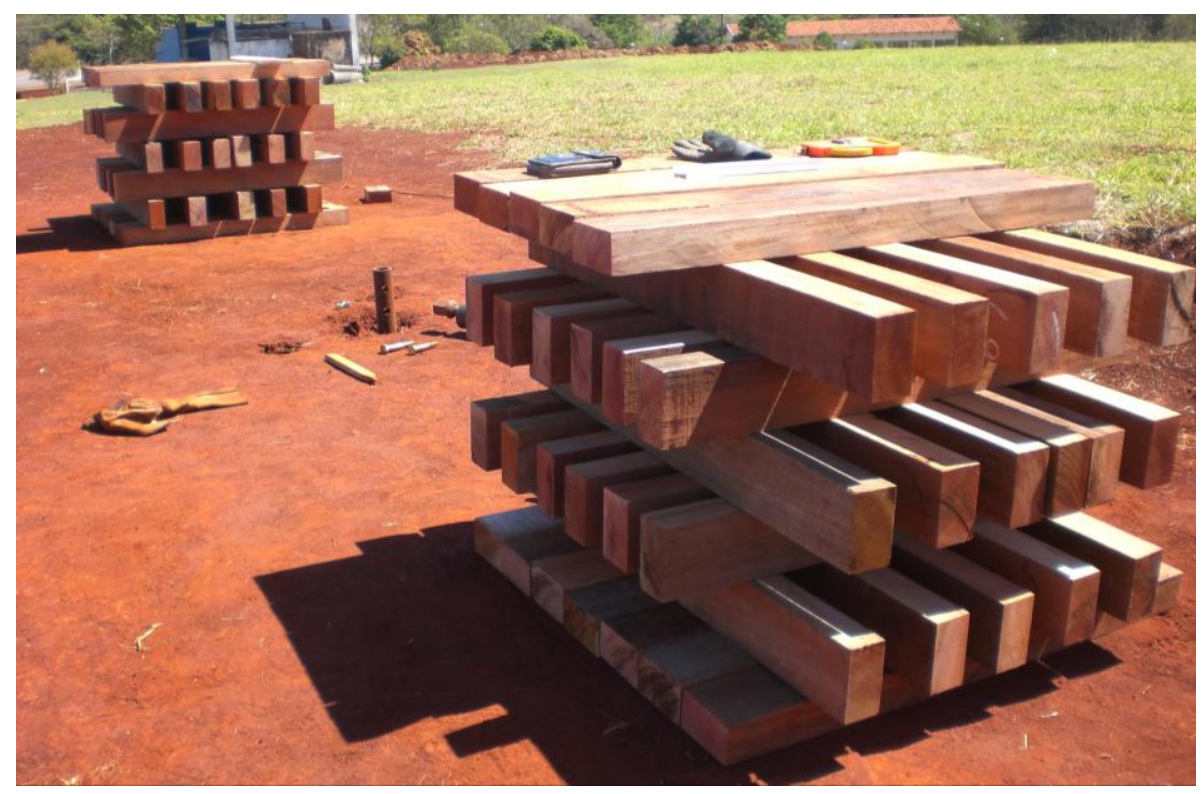

Figura 3.23: Fogueira de madeira utilizada como sistema de reação 
As distâncias das estacas às fogueiras de madeira nos ensaios garantem a não influencia entre as reações e a estaca ensaiada conforme recomenda a ASTM D 3689-07. Os relógios comparadores (Figura 3.20d) são apoiados em uma viga de referência isolada de todo o sistema de reação, e de aplicação de carga para não se ter influência da movimentação do sistema de reação nas leituras do topo da estaca. Estas vigas de referência foram fabricadas para o ensaio através de vigas e cantoneiras metálicas e foram pregadas ao chão em direção transversal ao sistema de reação, tal como é apresentada na Figura 3.26,

Para a transmissão de esforços entre macaco e estaca foi especialmente projetada uma peça de aço estrutural (aço carbono). Ela liga a estaca (através de parafusos) a uma barra de protensão (através de uma porca) que é tracionada pelo macaco hidráulico. Seu projeto detalhado está no ANEXO B, e a Figura 3.24 mostra a imagem da peça.

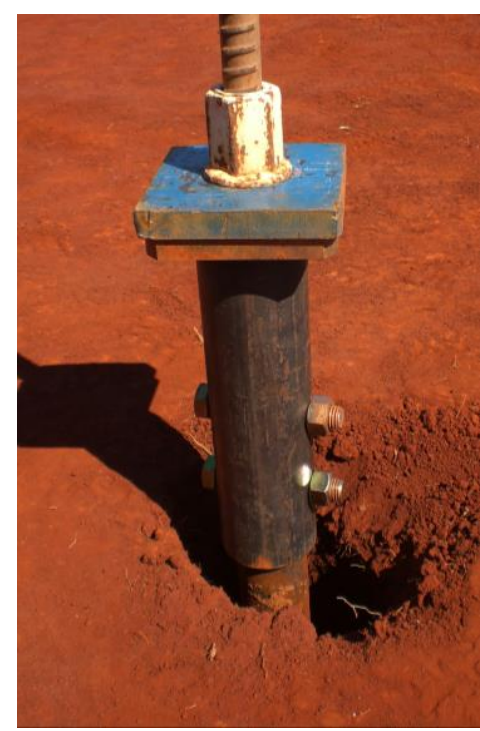

(a)

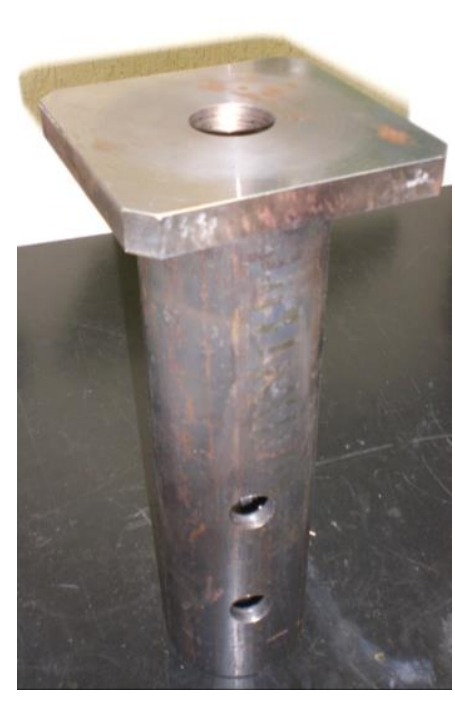

(b)

Figura 3.24: Peça de Acoplamento (a) instalada no campo e (b) isolada.

Por fim e maior entendimento das imagens e do sistema de reação explanado, as imagens nas Figura 3.25, Figura 3.26 e Figura 3.27 mostram os detalhes da montagem do sistema de reação e da colocação da viga. 


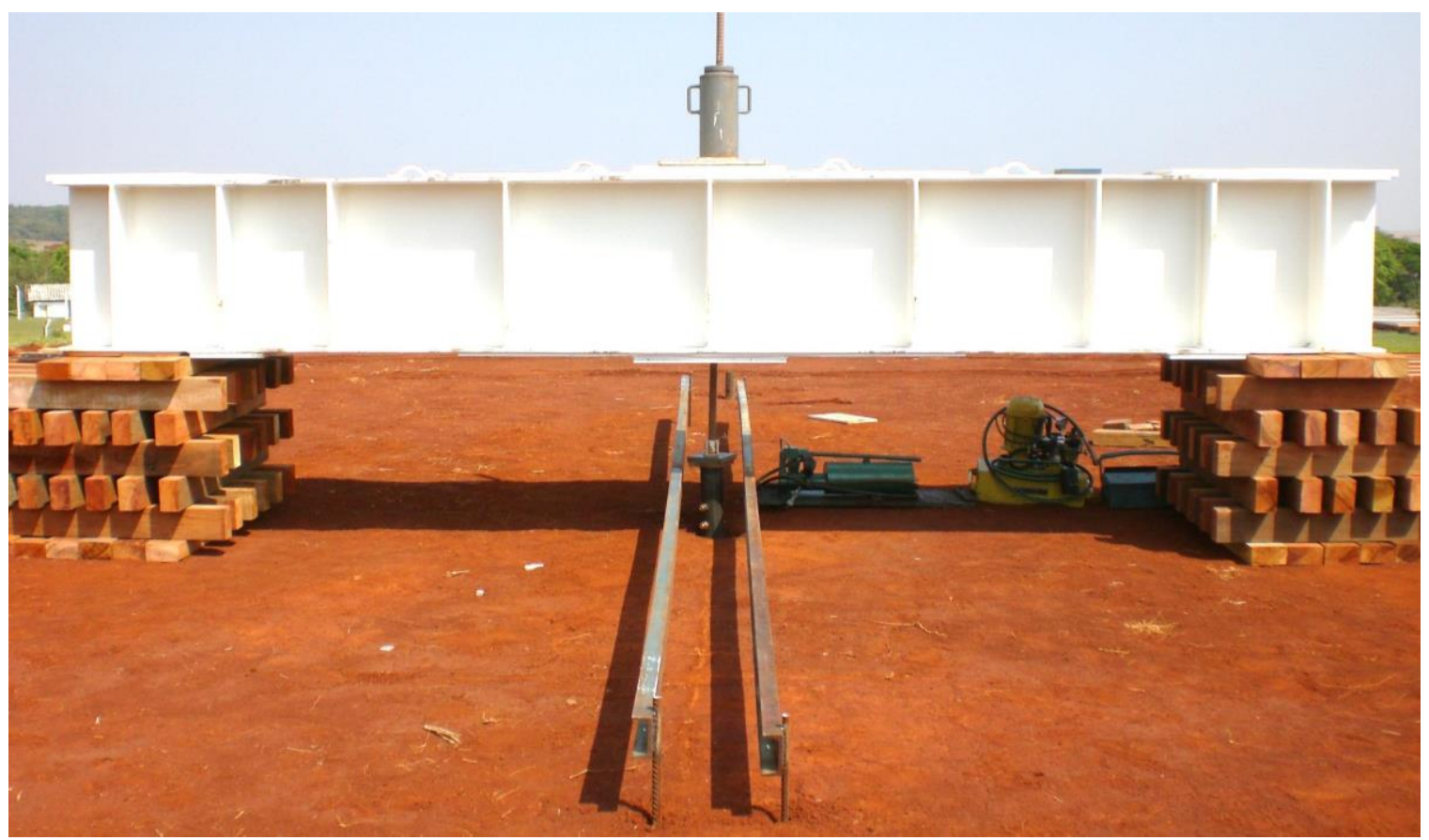

Figura 3.25: Visão frontal da prova de carga à tração, mesma vista da ilustração da Figura 3.21.

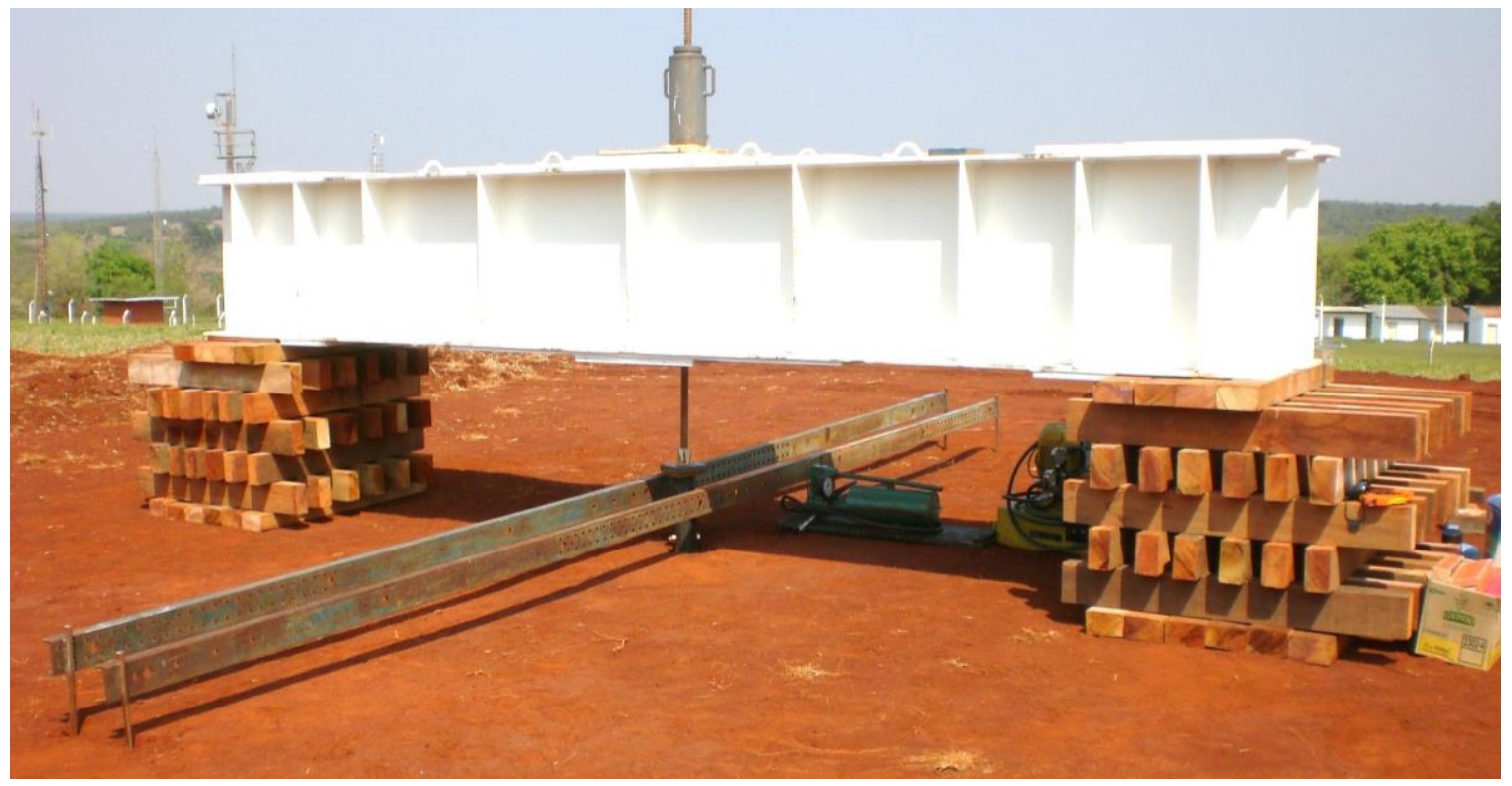

Figura 3.26: Visão do esquema de prova de carga com fogueira e vigas de referencia 


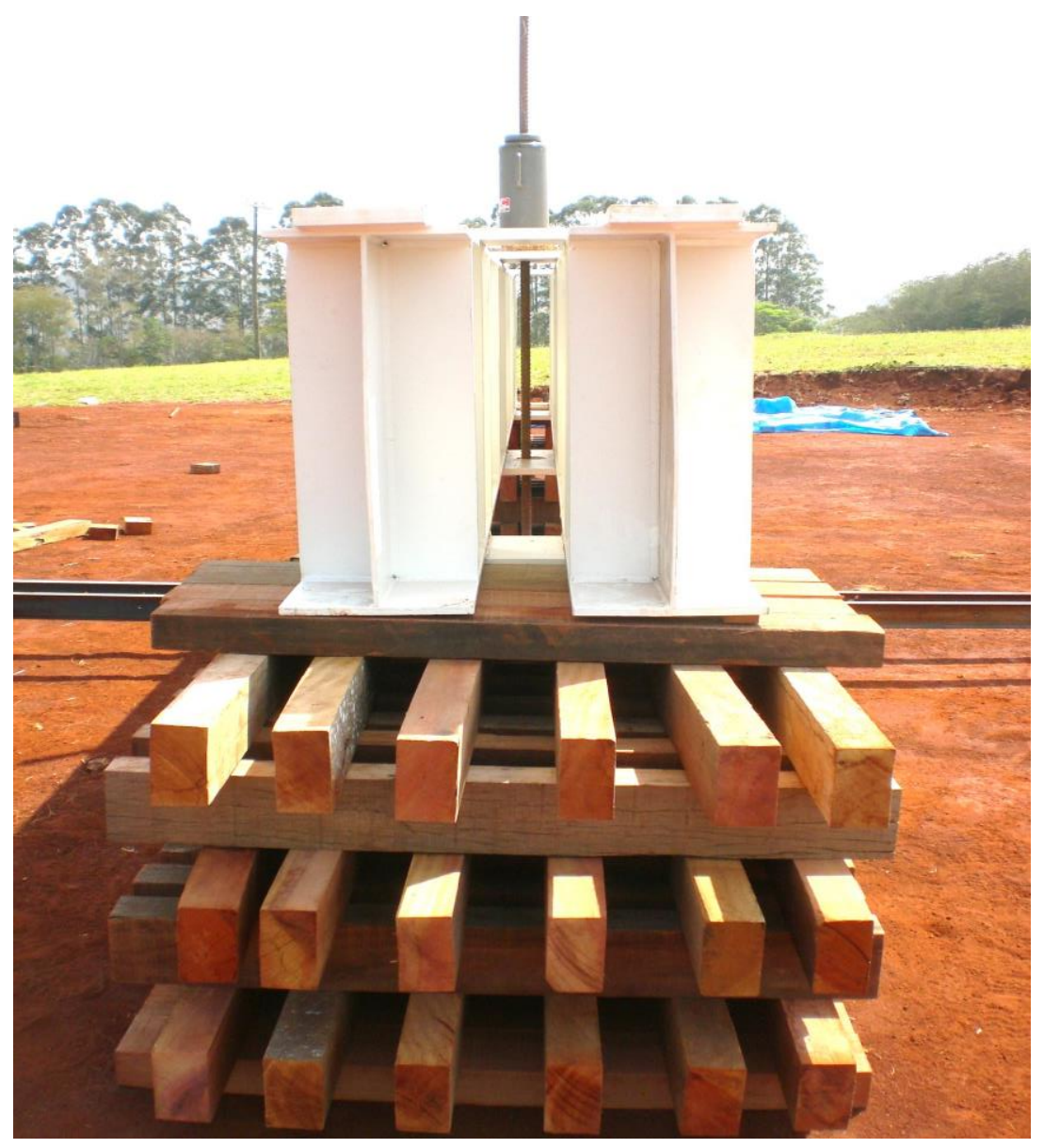

Figura 3.27: Visão da lateral (transversal) do sistema de reação da prova de carga a tração, mesma vista da ilustração da Figura 3.22.

\subsubsection{EXECUÇÃO DAS PROVAS DE CARGA}

As provas de cargas a tração foram do tipo estática rápida. Os estágios de carga foram de 5 minutos (recomendado pela NBR 12131/2006, nos casos de fundações de torres de linhas de transmissão), devido as ações principais sobre as torres serem de vento, ou seja, cargas rápidas de tração e compressão nas estacas.

Para cada prova de carga foram utilizados quatro relógios comparadores apoiados em 2 vigas de referência (Figura 3.28b). As cargas foram medidas através da célula de carga (ver equipamento azul na Figura 3.28a) e esta era ligada a um sistema de aquisição de dados. Para estes testes a célula de carga foi calibrada em prensa hidráulica com força cervo controlada no Departamento de Estruturas (SET) da EESC-USP. 


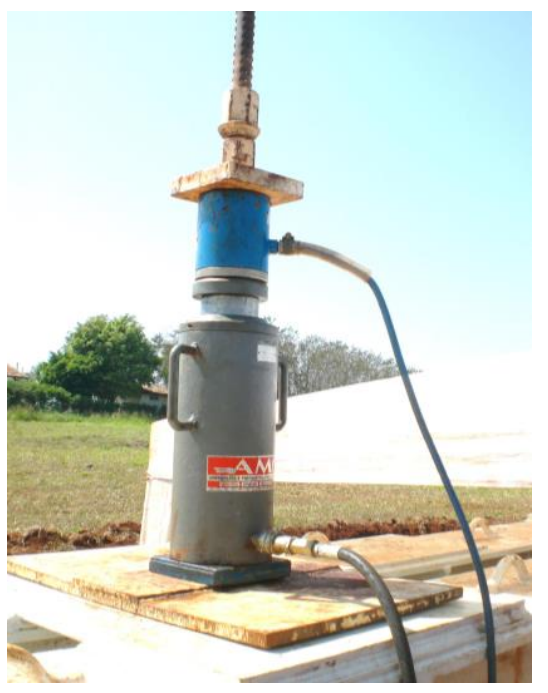

(a)

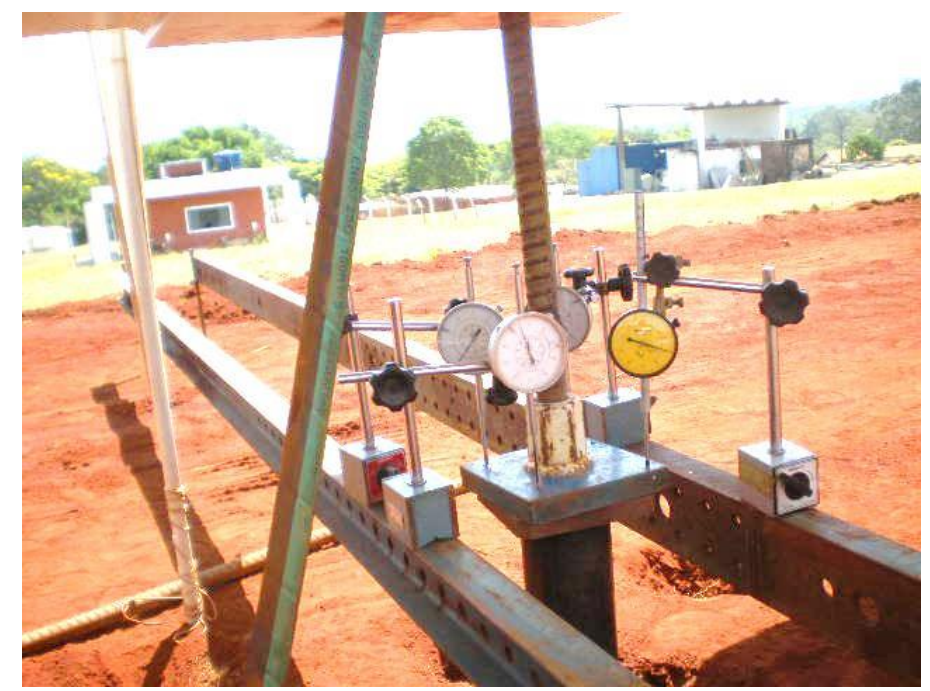

(b)

Figura 3.28: Imagens do (a) sistema de aplicação de carga e (b) dos quadro relógios comparadores nas duas vigas de referência.

Os equipamentos mecânicos e eletrônicos, os relógios comparadores (deflectômetros) e a equipe de ensaio foi protegido por barraca montada no local da viga. A proteção é importante para evitar a vibração da viga de referência devido ações do vento e para proteção contra o sol afim de diminuir variações de temperatura e consequentes efeitos de dilatação (Figura 3.29).
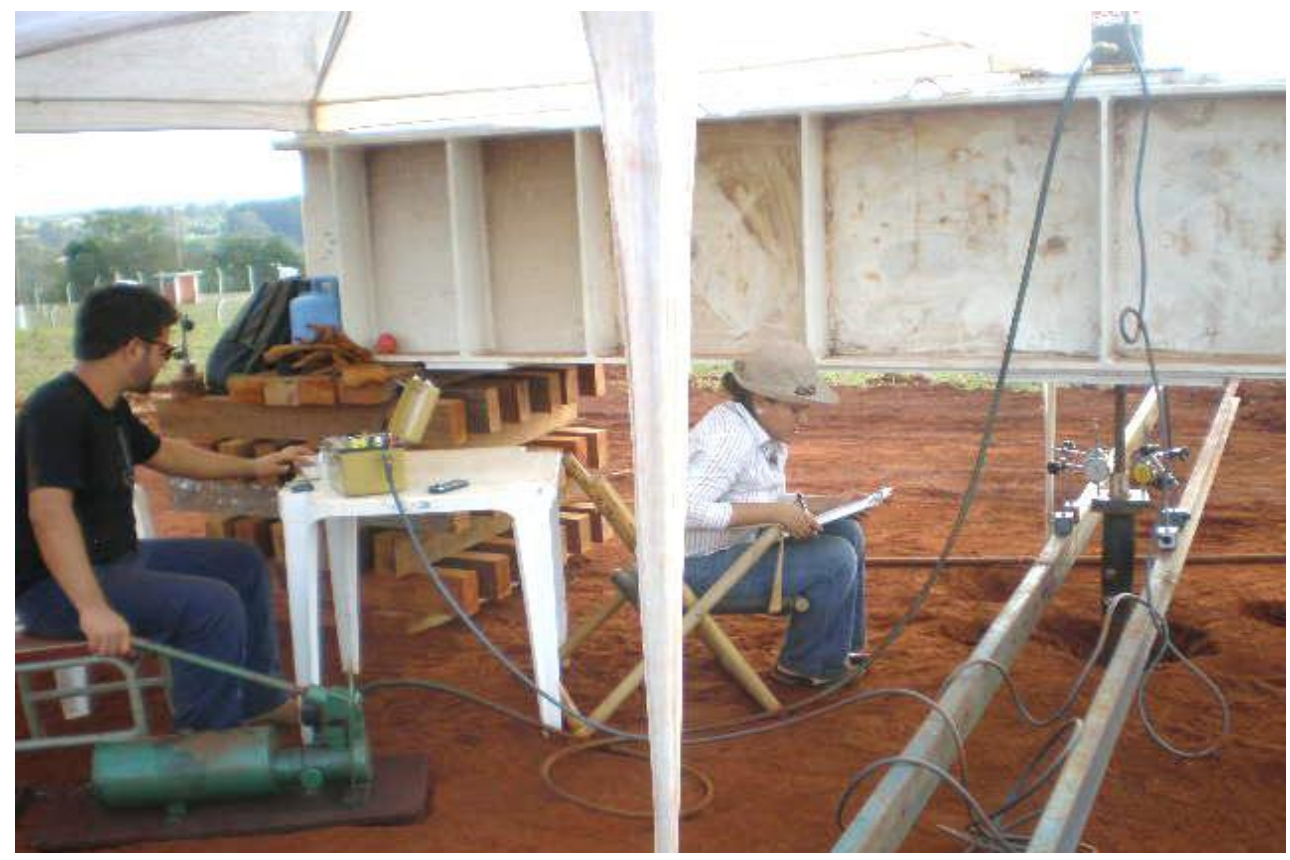

Figura 3.29: Ensaio de prova de carga a tração totalmente montado, realizado nesta pesquisa. 


\subsection{METODOLOGIA DAS ANÁLISES}

Os dados dos ensaios SPT e CPT foram comparados observando-se: a coerência dos resultados, a variabilidade do subsolo e a relação entre os 2 tipos de ensaios. Posteriormente, procedeu-se com a caracterização do subsolo obtendo-se suas respectivas propriedades geotécnicas.

Especificamente com os resultados do SPT foram obtidos os parâmetros de resistência do solo intacto e foram realizados os ensaios de teor de umidade higroscópica. Os valores de NSPT e de umidade foram utilizados para verificar a uniformidade horizontal do solo, validando as comparações entre as estacas devido a constatação de homogeneidade do solo.

Em relação aos ensaios CPT são avaliados os registros de qc e fs tanto nos pontos de referência em solo intacto ("virgem") quanto nos pontos próximos as estacas instaladas, onde se pretende verificar a alteração das propriedades do solo devido a instalação das estacas.

Devido a parada das estacas ser na cota $-10 \mathrm{~m}$, o torque final de instalação das estacas é o torque correspondente a profundidade de $10 \mathrm{~m}$. A partir destes torques medidos no final da instalação foi averiguada qual a influência das hélices em seu valor, tanto da sua quantidade quanto do seu diâmetro. Foi também verificada a proporcionalidade entre quantidade de hélices e o acréscimo no valor de torque, as alterações dos valores de torque com o uso de hélices iguais ou crescentes em estacas de uma hélice ou multi-hélices. Também avaliou-se a relação entre torque de instalação e os resultados dos ensaios SPT. Por fim, avaliou-se a relação entre o torque e a capacidade de carga e os fatores que interferem nesta correlação.

Com relação aos métodos de previsão de capacidade de carga analisou-se quão os métodos consideram a configuração das hélices, além de quais e como os mesmos consideram o efeito da mudança das propriedades do solo com a instalação da estaca.

Com os resultados das provas de carga, se analisou a eficiência dos métodos de previsão. Também se analisou a contribuição de cada hélice na capacidade de carga da estaca. Efetuou-se uma retro análise para a obtenção dos parâmetros dos solos modificados com a instalação da estaca, através do uso dos métodos de previsão de capacidade de carga comparados com as 
provas de carga. Estudou-se a relação da capacidade de carga com o torque de instalação, em busca de averiguar como a configuração das hélices influencia nesta relação.

E por fim, para interpretação dos resultados das provas de carga foi utilizado o critério de ruptura D/10 de Terzaghi (1942) apud Zhang (1999) para rupturas convencionais. Este critério é utilizado em outros trabalhos com provas de carga em estacas helicoidais como, por exemplo, o Livneh e Naggar (2008). Ou seja, a carga última é a carga correspondente ao deslocamento de $10 \%$ do diâmetro médio da hélice da estaca. 


\section{CAPITULO 4 - RESULTADOS}

Neste capítulo são apresentados os resultados dos ensaios realizados para esta pesquisa.

\subsection{INVESTIGAÇÕES GEOTÉCNICAS}

Os resultados das investigações geotécnicas (SPT e CPT) e as interpretações das mesmas são apresentados neste item.

\subsubsection{UMIDADE GRAVIMÉTRICA}

O teor de umidade foi medido de metro em metro (Tabela 4.1) a partir das amostras retiradas nos ensaios SPT, conforme descrito previamente no CAPITULO 3 - MATERIAIS E MÉTODOS. A variação da umidade ao longo da profundidade é mostrada na Figura 4.1

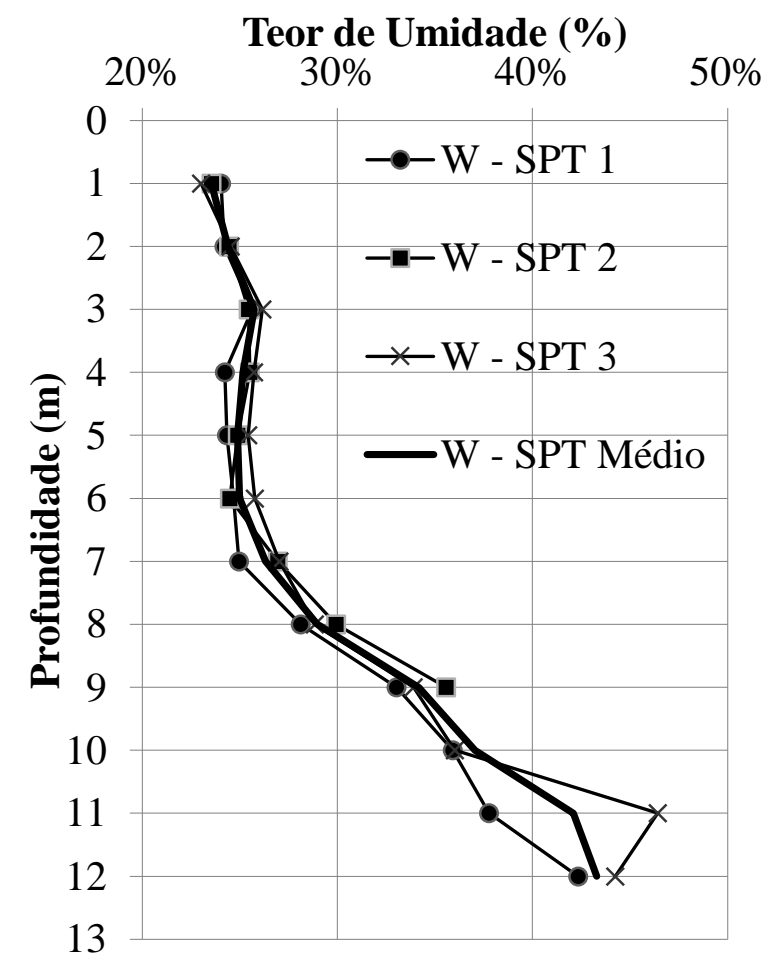

Figura 4.1: Gráfico do teor de umidade vs profundidade baseado a amostragem dos ensaios SPT 
Não houve constatação de lençol freático (N.A.) nem com os ensaios SPT nem CPT, portanto, pressupõe-se que os resultados encontrados refletem o teor de umidade de um solo nãosaturado.

Tabela 4.1: Valores do Teor de umidade gravimétrica ao longo da profundidade baseado na amostragem do ensaio SPT.

\begin{tabular}{ccccc}
\hline \multicolumn{5}{c}{ W - Umidade Gravimétrica (\%) } \\
\hline Profundidade (m) & SPT 1 & SPT 2 & SPT 3 & SPT Medio \\
\hline $\mathbf{0}$ & - & - & - & - \\
\hline $\mathbf{1}$ & $24 \%$ & $24 \%$ & $23 \%$ & $\mathbf{2 4 \%}$ \\
\hline $\mathbf{2}$ & $24 \%$ & $24 \%$ & $25 \%$ & $\mathbf{2 4 \%}$ \\
\hline $\mathbf{3}$ & $26 \%$ & $25 \%$ & $26 \%$ & $\mathbf{2 6 \%}$ \\
\hline $\mathbf{4}$ & $24 \%$ & $26 \%$ & $26 \%$ & $\mathbf{2 5 \%}$ \\
\hline $\mathbf{5}$ & $24 \%$ & $25 \%$ & $25 \%$ & $\mathbf{2 5 \%}$ \\
\hline $\mathbf{6}$ & $25 \%$ & $24 \%$ & $26 \%$ & $\mathbf{2 5 \%}$ \\
\hline $\mathbf{7}$ & $25 \%$ & $27 \%$ & $27 \%$ & $\mathbf{2 6 \%}$ \\
\hline $\mathbf{8}$ & $28 \%$ & $30 \%$ & $29 \%$ & $\mathbf{2 9 \%}$ \\
\hline $\mathbf{9}$ & $33 \%$ & $36 \%$ & $34 \%$ & $\mathbf{3 4 \%}$ \\
\hline $\mathbf{1 0}$ & $36 \%$ & $39 \%$ & $36 \%$ & $\mathbf{3 7 \%}$ \\
\hline $\mathbf{1 1}$ & $38 \%$ & - & $46 \%$ & $\mathbf{4 2 \%}$ \\
\hline $\mathbf{1 2}$ & $42 \%$ & - & $44 \%$ & $\mathbf{4 3 \%}$ \\
\hline $\mathbf{1 3}$ & $40 \%$ & - & $21 \%$ & $\mathbf{3 1 \%}$ \\
\hline
\end{tabular}

Os resultados se mostraram semelhantes nos três furos de SPT, atendendo assim a hipótese de uniformidade horizontal do solo em área na região dos ensaios. Deste modo, a sucção e o teor de umidade não são variáveis do problema, sendo possível assim comparar as estacas entre si. 


\subsubsection{ENSAIO SPT}

Dentre os três ensaios realizados dois alcançaram o impenetrável e o outro apenas desceu até a profundidade de 10m (Figura 4.2). Os relatórios de campo do SPT estão na íntegra no ANEXO A.

Para os três furos de ensaio SPT, foram obtidos os gráficos dos valores de $\mathrm{N}_{\text {SPT }}$ ao longo da profundidade apresentados na Figura 4.2. O perfil geotécnico com as interpretações tátilvisuais do ensaio SPT e os valores de $\mathrm{N}_{\text {SPT }}$ são mostrados na Figura 4.3.

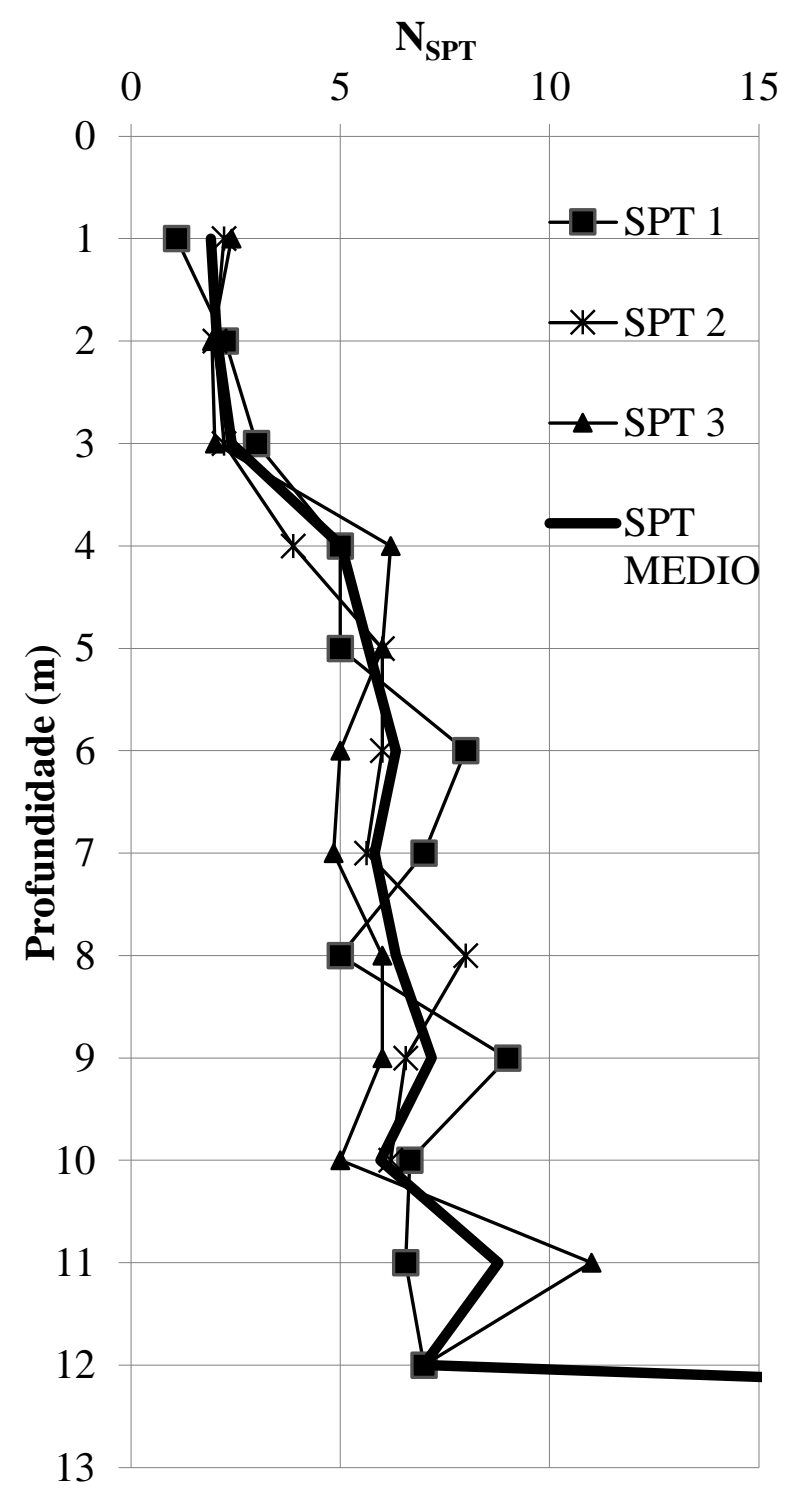

Figura 4.2: Gráfico dos resultado índice SPT. 
O campus em questão se encontra num perfil pedológico de solo com comportamento laterítico (solo tropical) e a caracterização geológica do item 3.2.4. Sendo assim, o solo da camada superficial é cimentado, com relevante presença de hidróxido de ferro (avermelhados) e poroso.

Conforme a Figura 4.3 o perfil de solo encontrado é constituído por uma pequena camada orgânica, seguida de um solo transportado laterizado de argila arenosa fina vermelha, até as proximidades de $6 \mathrm{~m}$. Em seguida, é encontrado um solo argiloso com pedregulhos, seixos, de cor avermelhada a variegada até em torno de $8 \mathrm{~m}$. Abaixo se encontra uma camada de solo residual de alteração de basalto, silte areno argiloso. Esta última camada é de um solo de alteração de basalto, amarelado a variegado. Por fim, encontra-se o impenetrável entre 13 e 14,5m. (variação do impenetrável encontrada tanto nos ensaios SPT quanto nos ensaios CPT). Não foi detectado lençol freático ou nível d’água.

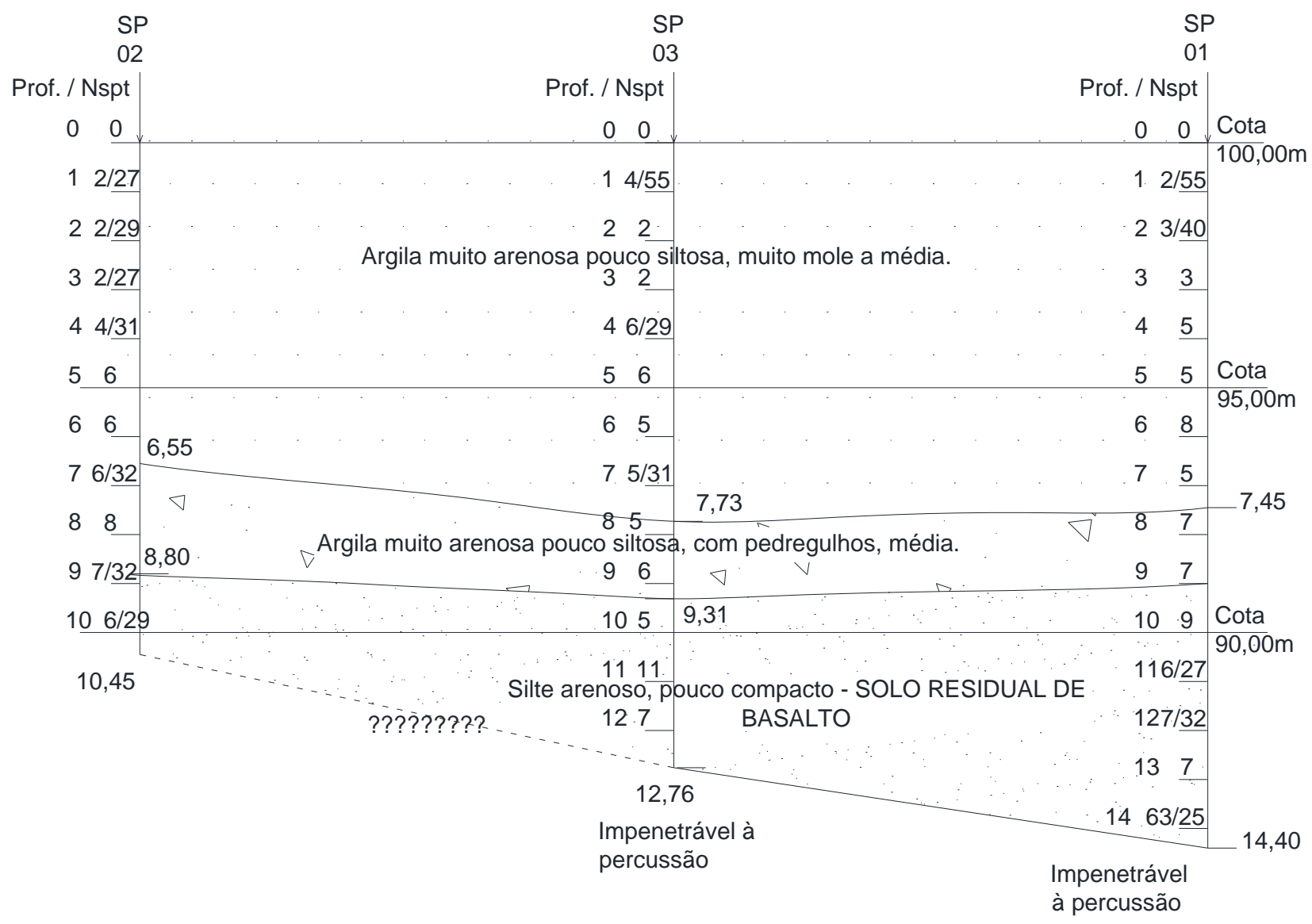

Figura 4.3: Perfil Interpretado do solo com base nos 3 ensaios SPT. 
Segue na Tabela 4.2 os valores do $\mathrm{N}_{\mathrm{SPT}}$ em formato de planilha.

Tabela 4.2: Valores do índice de penetração $\mathrm{N}_{\text {SPT }}$ vs profundidade de ensaio

\begin{tabular}{ccccc}
\hline Prof $(\mathbf{m})$ & SPT 1 & SPT 2 & SPT 3 & SPT MEDIA \\
\hline 0 & - & - & - & - \\
\hline 1 & 1 & 2 & 2 & 2 \\
\hline 2 & 2 & 2 & 2 & 2 \\
\hline 3 & 3 & 2 & 2 & 2 \\
\hline 4 & 5 & 4 & 6 & 5 \\
\hline 5 & 5 & 6 & 6 & 6 \\
\hline 6 & 8 & 6 & 5 & 6 \\
\hline 7 & 7 & 6 & 5 & 6 \\
\hline 8 & 5 & 8 & 6 & 6 \\
\hline 9 & 9 & 7 & 6 & 7 \\
\hline 10 & 7 & 6 & 5 & 6 \\
\hline 11 & 7 & - & 11 & 9 \\
\hline 12 & 7 & - & 7 & 7 \\
\hline 13 & 76 & - & - & 76 \\
\hline
\end{tabular}

Em geral os resultados do índice SPT mostram que o solo é de baixa resistência a média, melhorando com a profundidade. No entanto, os índices não ultrapassam o valor de 9 golpes $/ 30 \mathrm{~cm}$ até a profundidade de $10 \mathrm{~m}$ (substrato de solo onde as estacas estão inseridas), possuindo assim baixos níveis de resistência na região exigida durante as provas de carga a tração realizadas. 


\subsubsection{ENSAIO CPT}

Neste item são exibidos os resultados dos ensaios CPT. Na Figura 4.4 é exposto o perfil do solo interpretado usando os resultados de tais ensaios.

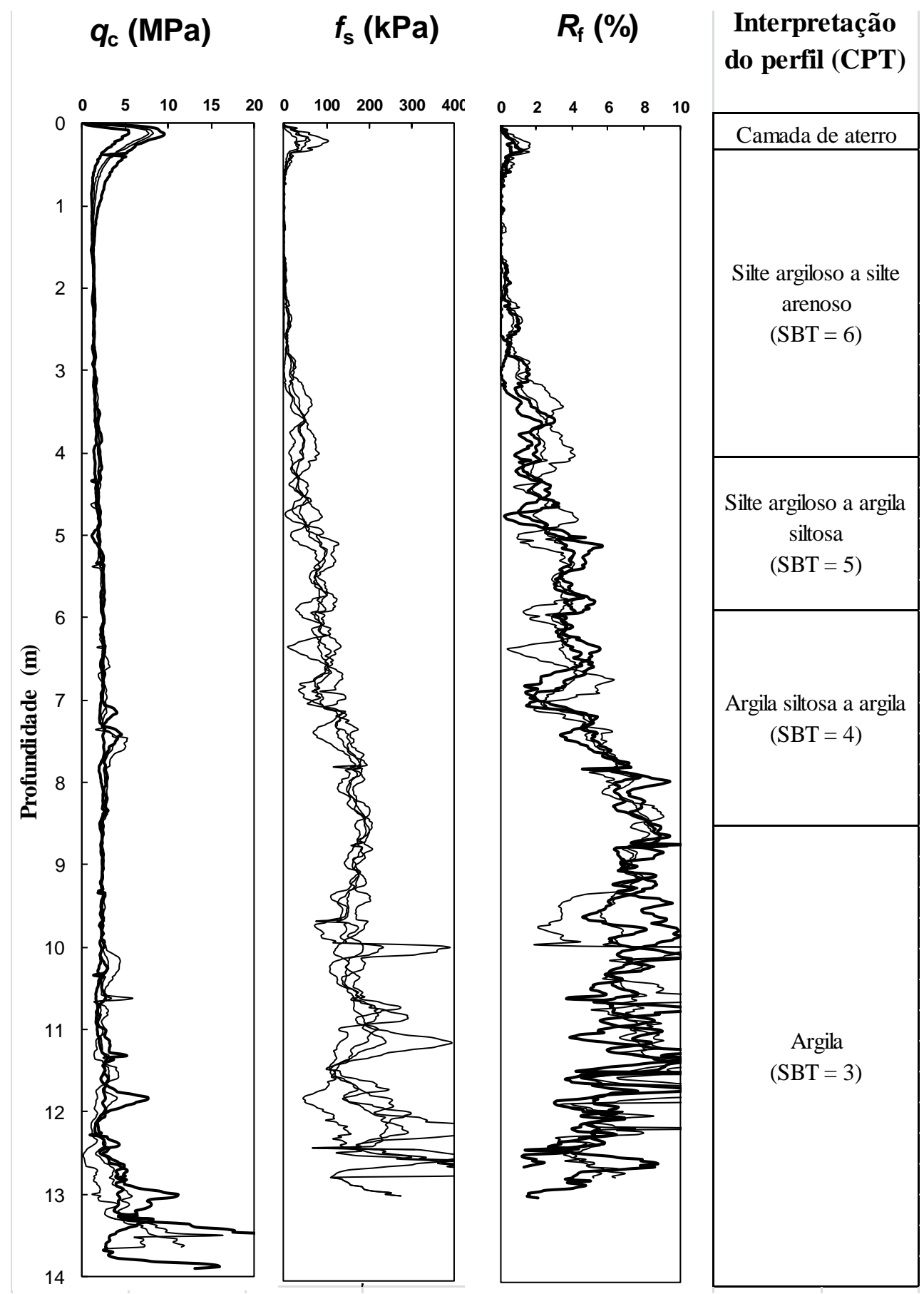

Figura 4.4: Gráficos com os resultados dos 3 ensaios CPT (resistência de ponta, qc; resistência lateral, fs; razão de atrito, Rs) e a interpretação do Perfil de acordo com Robertson et al. (1986). 
Com o resultados do ensaio CPT foi gerado o perfil do solo a partir das interpretações de

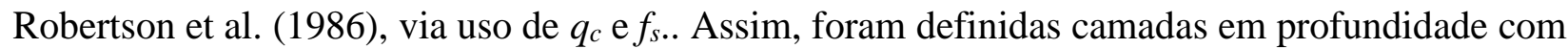
propriedades e identificações semelhantes para obtenção dos parâmetros representativos de cada camada.

Na Tabela 4.3 são apresentadas as camadas adotadas e as suas respectivas profundidades e parâmetros, que possibilitaram sua identificação conforme apresentado na Figura 4.4 e Figura 4.5. Devido não haver nível de água ou pressão neutra os valores de $q_{c}$ são iguais a $q_{t}$.

Tabela 4.3: Interpretação dos Resultados de CPT para classificação dos perfis de solo.

\begin{tabular}{cccc|cc} 
Camada & & $\boldsymbol{q}_{\boldsymbol{c}}\left(\boldsymbol{q}_{\boldsymbol{t}}\right)$ & $\mathbf{f s}$ & \multicolumn{2}{c}{ Classificação SBT } \\
\hline $\mathbf{N}^{\mathbf{0}}$ & Prof. $(\mathbf{m})$ & $(\mathbf{M P a})$ & $\boldsymbol{\%}$ & $\begin{array}{c}\text { Indice } \\
\text { SBT }\end{array}$ & $\begin{array}{c}\text { Tipo de comportamento do } \\
\text { solo }\end{array}$ \\
\hline 1 & $0,5-3$ & 1,4 & 0,1 & $\mathbf{6}$ & Silte arenoso a silte argiloso \\
\hline 2 & $3-5$ & 1,4 & 2 & $\mathbf{5}$ & Silte argiloso a argila siltosa \\
\hline 3 & $5-8$ & 2,5 & 3,8 & $\mathbf{4}$ & Argila siltosa a argila \\
\hline 4 & $8-10$ & 2,5 & 7,2 & $\mathbf{3}$ & Argila \\
\hline 5 & $10-14$ & 3 & 7,2 & $\mathbf{3}$ & Argila \\
\hline
\end{tabular}

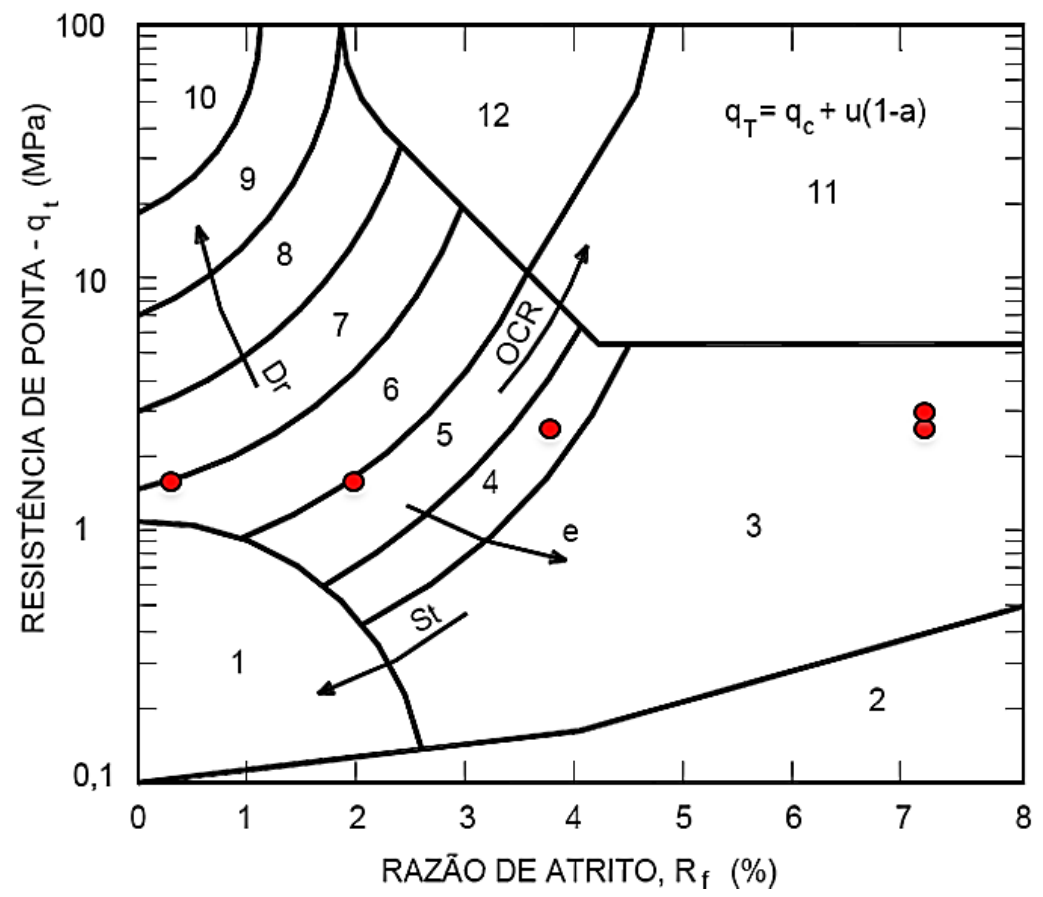

Figura 4.5: Gráfico com a indicação em vermelho de todas as camadas resultantes do ensaio CPT. 
Todos os resultados apresentados na Figura 4.4, Figura 4.5 e Tabela 4.6 são dos ensaios executados para a caracterização das propriedades do solo intacto, antes da instalação das estacas. No entanto, também foram realizados posteriormente ensaios CPT próximos as estacas após sua instalação no terreno, e anteriormente à execução dos ensaios de prova de carga a tração.

Os ensaios próximos às estacas são apresentados em planta na Figura 3.8 indicados pela legenda "sondagem CPT (solo perturbado). As distâncias em planta entre eixos dos furos do ensaio CPT próximos as estacas (no solo perturbado) e as próprias estacas são indicadas na Tabela 4.4.

Tabela 4.4: Relatório dos furos CPT com distância do eixo de cada furo ao eixa da estaca em questão

\begin{tabular}{lcccccccccc}
\hline \multicolumn{10}{c}{ Distância do furo CPT a estaca helicoidal (eixo a eixo) } \\
\hline Estaca & R & A1 & A2 & A3 & B1 & B2 & B3 & C2 & C3 \\
\hline d medido $(\mathbf{m m})$ & 240 & 390 & $437 / 837$ & 300 & 280 & 235 & 300 & 255 & 360 \\
\hline
\end{tabular}

\subsubsection{INTERPRETAÇÃO ACLOPADA DO PERFIL GEOTÉCNICO}

Neste item é apresentado o comparativo entre os resultados encontrados nos ensaios SPT e CPT realizados antes da instalação da estaca no campus do CRHEA. Como pode ser percebido na Figura 4.6, os resultados são coerentes. Tanto os resultados dos ensaios CPT quanto dos ensaios SPT apresentaram valores baixos de resistência à penetração

O SPT é interpretado tátil visualmente através das amostras e o CPT indiretamente através da interpretação dos resultados através dos gráficos de classificação de Robertson et al. (1986). Apesar das compreensíveis diferenças de classificação, devido as diferentes interpretações entre os ensaios, as mudanças e espessuras de camadas se assemelham e os níveis de resistências também. 


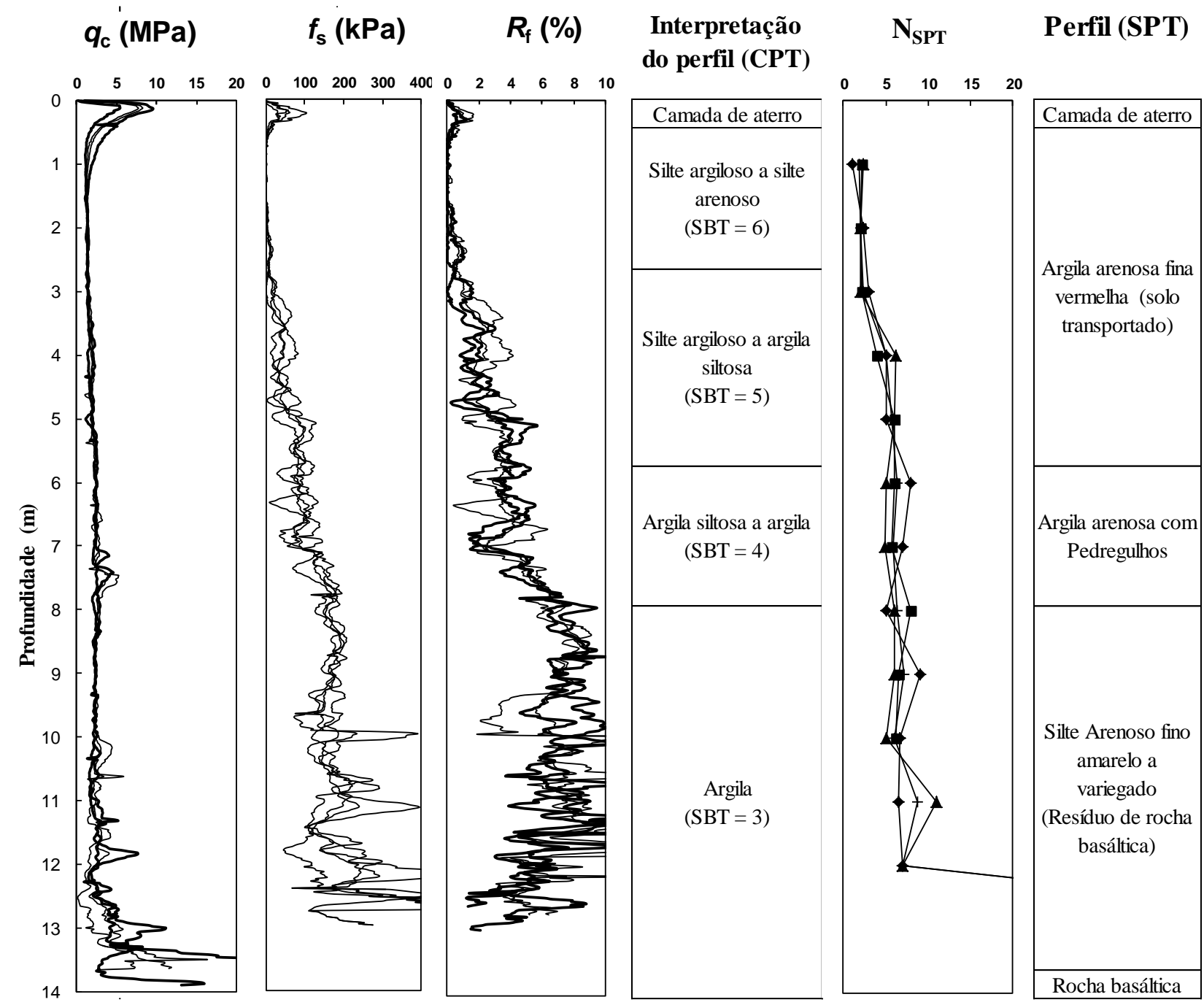

Figura 4.6: Resumo com gráficos comparativos dos resultados de CPT e SPT.

\subsection{INSTALAÇÃO DAS ESTACAS}

As estacas foram instaladas conforme o esquema em planta apresentado na Figura 3.16. A profundidade de parada da ponta das estacas foi de 10 metros. Para a realização das provas de carga foi necessário que as estacas ficassem com um trecho final do topo das hastes exposto para o acoplamento com o sistema de reação, possibilitando-se a aplicação de tração nas estacas durante os ensaios. As medidas de comprimento dos trechos de estaca que ficaram acima do nível do terreno para este acoplamento são apresentadas na Tabela 4.5. 
Tabela 4.5: Comprimentos da haste da estaca helicoidal acima do nível do terreno, valores em $\mathrm{cm}$.

\begin{tabular}{ccccccccccc}
\hline \multicolumn{10}{c}{ Comprimento da Estaca fora do solo - L não instalado } \\
\hline Estaca & R & A1 & A2 & A3 & B1 & B2 & B3 & C2 & C3 \\
\hline L medido (cm) & 24,5 & 22 & 23,1 & 26 & 24 & 29 & 26 & 29 & 27 \\
\hline
\end{tabular}

\subsubsection{TORQUES DE INSTALAÇÃO}

Neste tópico são apresentados os valores de torque aplicados na haste das estacas necessários a instalação destas. A Tabela 4.6 mostra os valores de torque medidos ao final da instalação para todas as estacas ensaiadas, tais valores foram obtidos conforme detalhado no item 3.4.2- Execução da Instalação.

Tabela 4.6: Torque final de instalação das estacas helicoidais.

\begin{tabular}{c|c|c|c|c|c|c|c|c|c|c|c}
\hline \multirow{2}{*}{ Prof $(\mathbf{m})$} & \multicolumn{10}{c}{ Torques Finais de Instalação (kN.m) - Prof. De 10m } \\
\cline { 2 - 11 } & R & A1 & A2 & A3 & B1 & B2 & B3 & C2 & C3 & B1 em F.T. & Retirada B1 \\
\hline 10 & 5,01 & 4,58 & 4,85 & 5,11 & 4,38 & 5,05 & 6,11 & 5,98 & 6,97 & 4,48 & 2,79 \\
\hline
\end{tabular}

A Figura 4.7 ilustra todos os gráficos de torque x profundidade resultantes da instalação de todas as estacas. Os gráficos de grupos de estacas com propriedades ou características semelhantes são apresentados nas Figura 4.8 a Figura 4.13.

A Figura 4.8 mostra as estacas do Modelo A; a Figura 4.9 as estacas do Modelo B; a Figura 4.10 as estacas do Modelo C; a Figura 4.11 as estacas com apenas 1 hélice; a Figura 4.12 as estacas com 2 hélices; a Figura 4.13 as estacas com 3 hélices, a Figura 4.14 todos os torques apresentados apenas entre as profundidades das hélices (entre $7 \mathrm{~m}$ e 10m). 


\section{Torques de Instalação - Todas as Estacas}

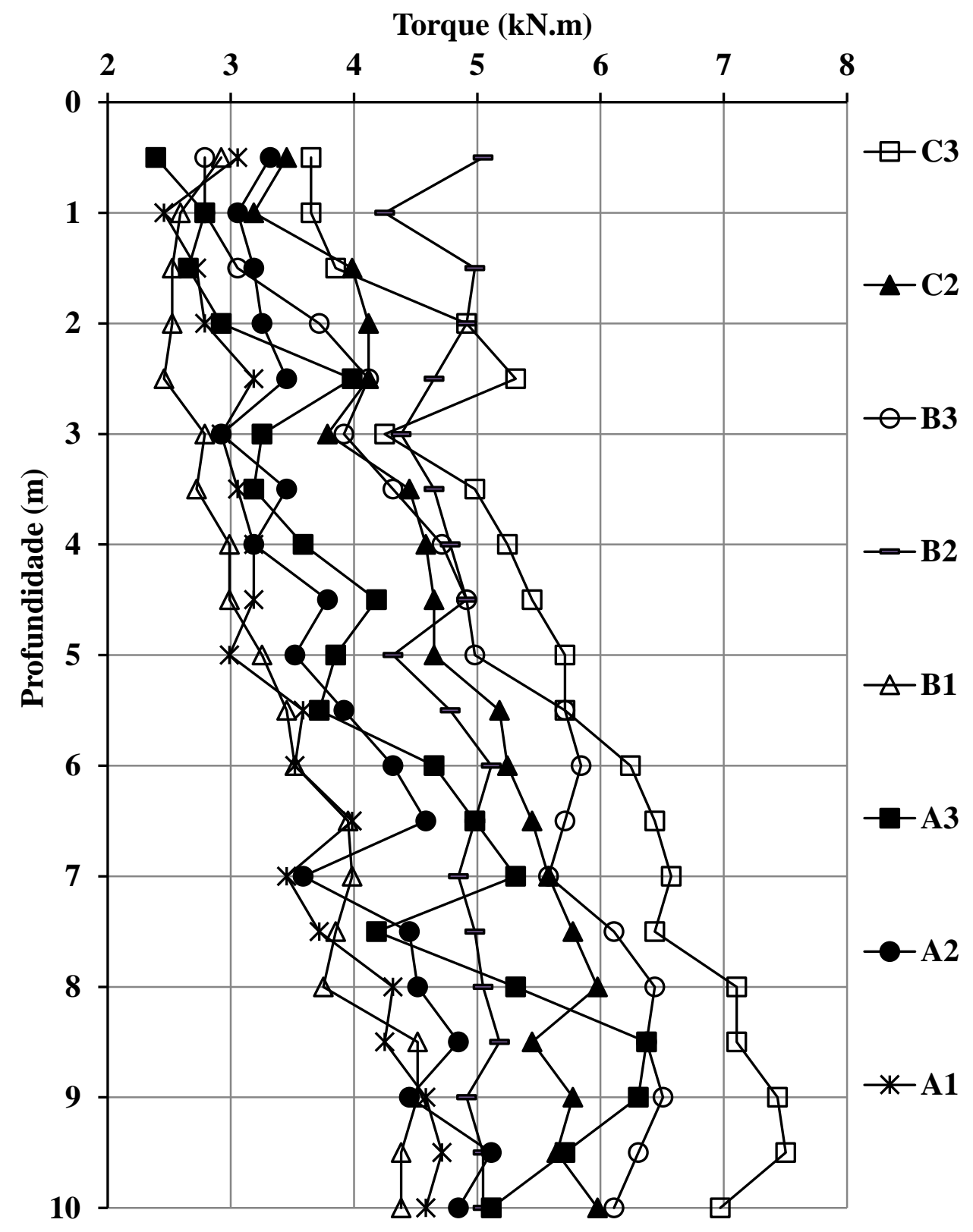

Figura 4.7: Medições de torque de todas as estacas ao longo da profundidade de instalação. 


\section{Torques de Instalação - Hélices de diâmetros Iguais (A)}

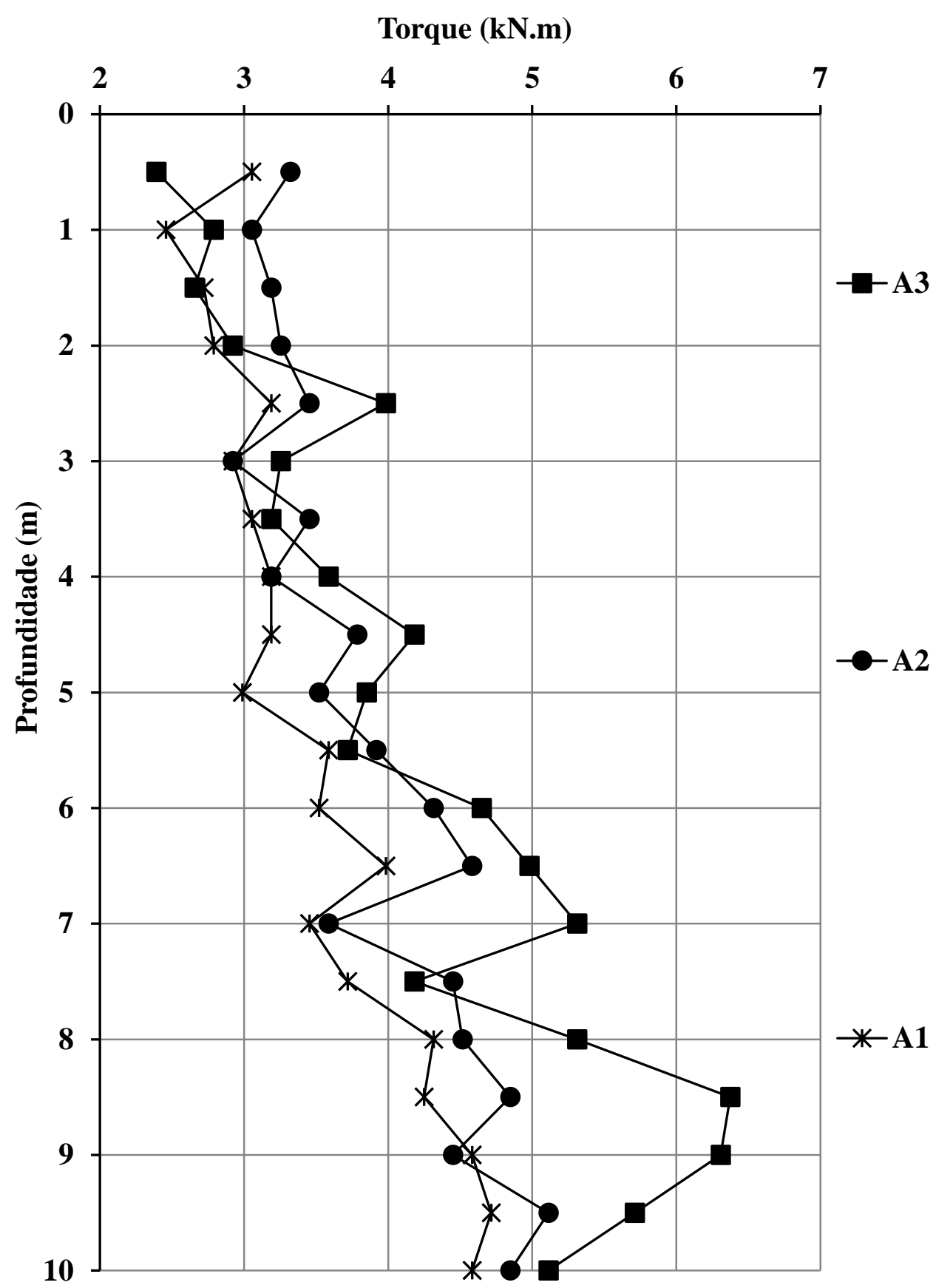

Figura 4.8: Gráficos do torque de instalação para estacas do modelo A - (hélices de mesmo diâmetro igual a $20 \mathrm{~cm}$ 


\section{Torques de Instalação - Hélices Crescentes (B)}

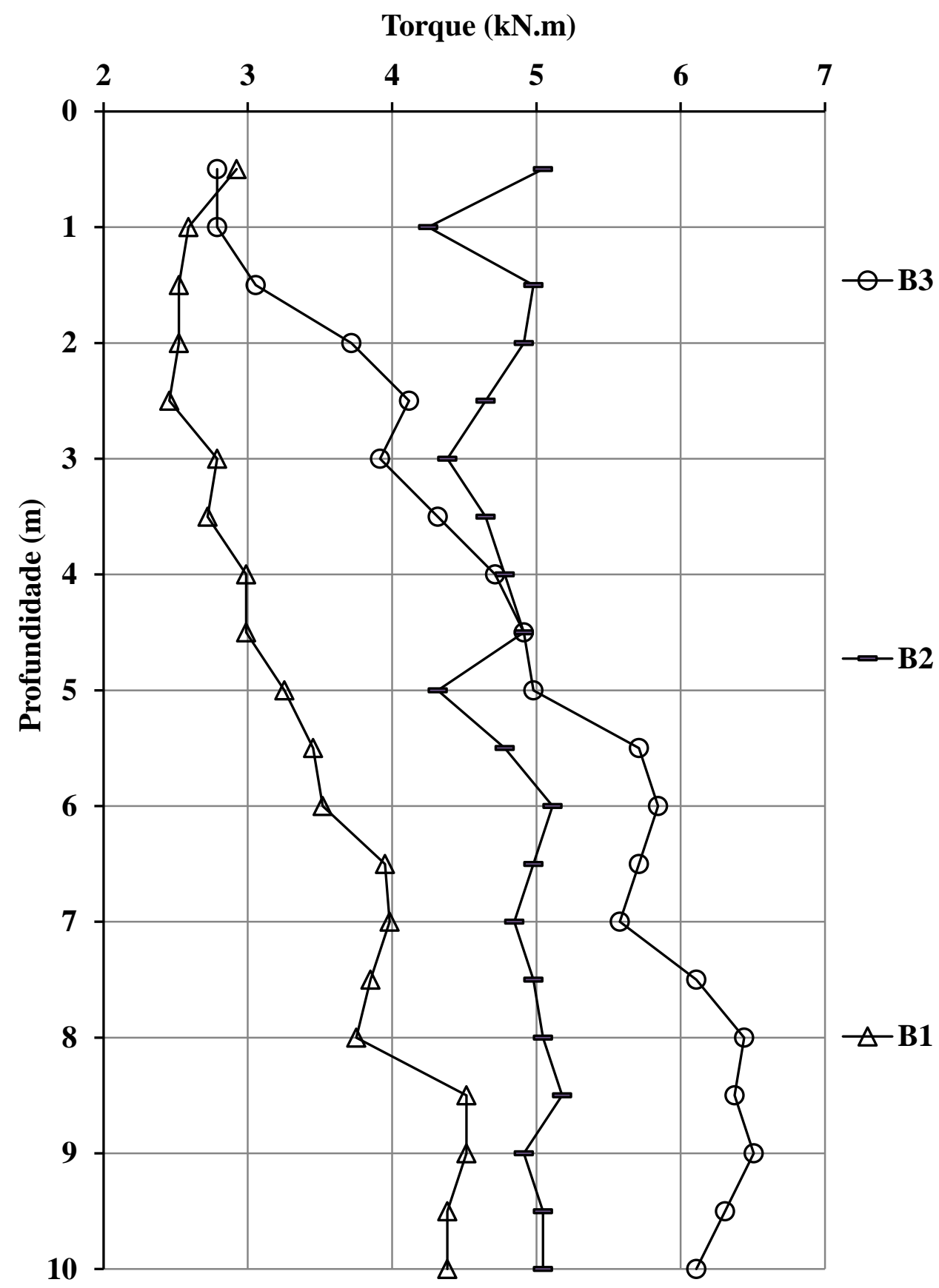

Figura 4.9: Gráficos do torque de instalação para estacas do modelo B (diâmetros das hélices são crescentes 


\section{Torques de Instalação - Hélices Crescentes (C)}

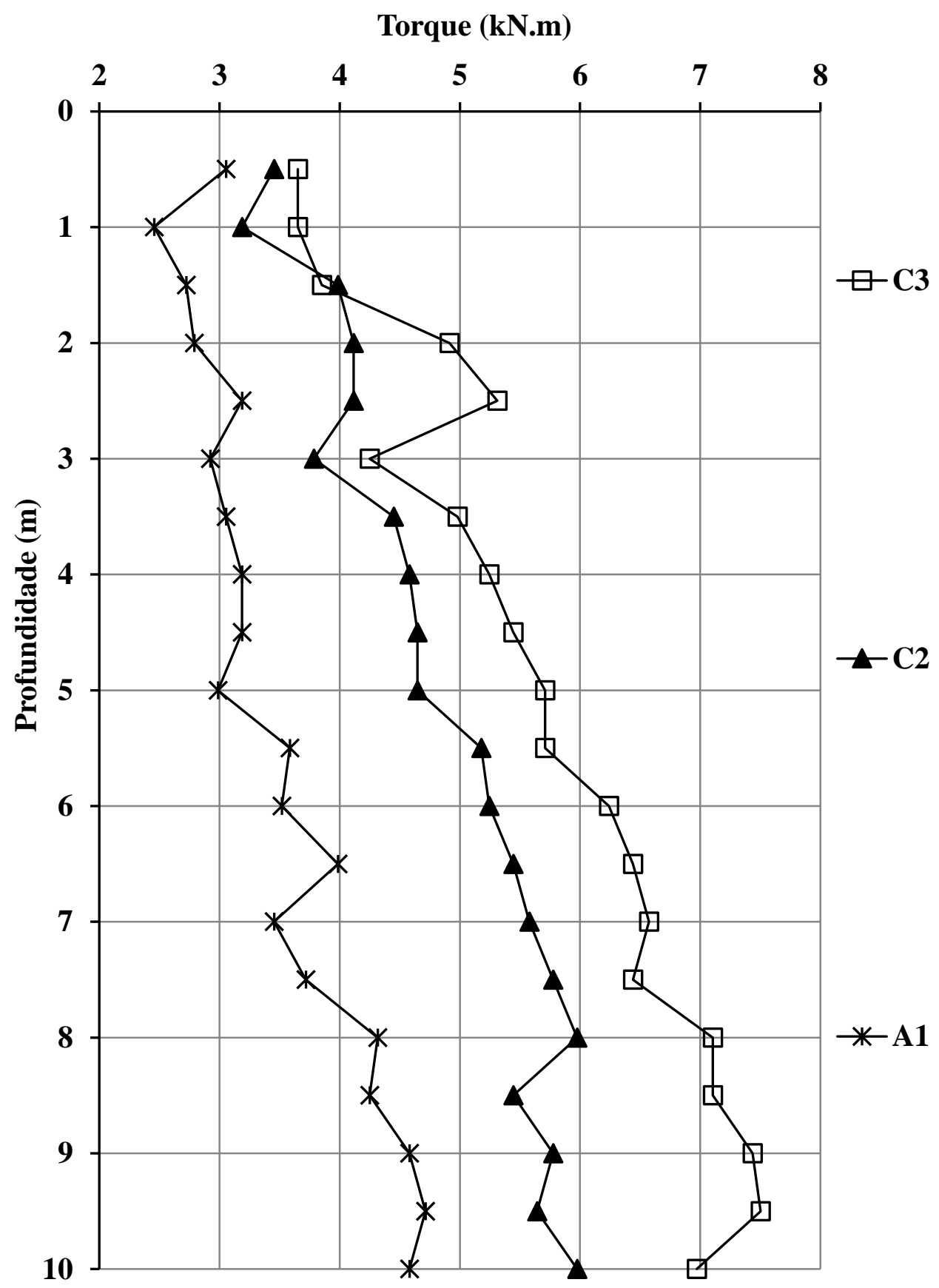

Figura 4.10: Gráficos do torque de instalação para estacas do modelo C (diâmetros das hélices são crescentes). 


\section{Torques de Instalação - 1 Hélice}

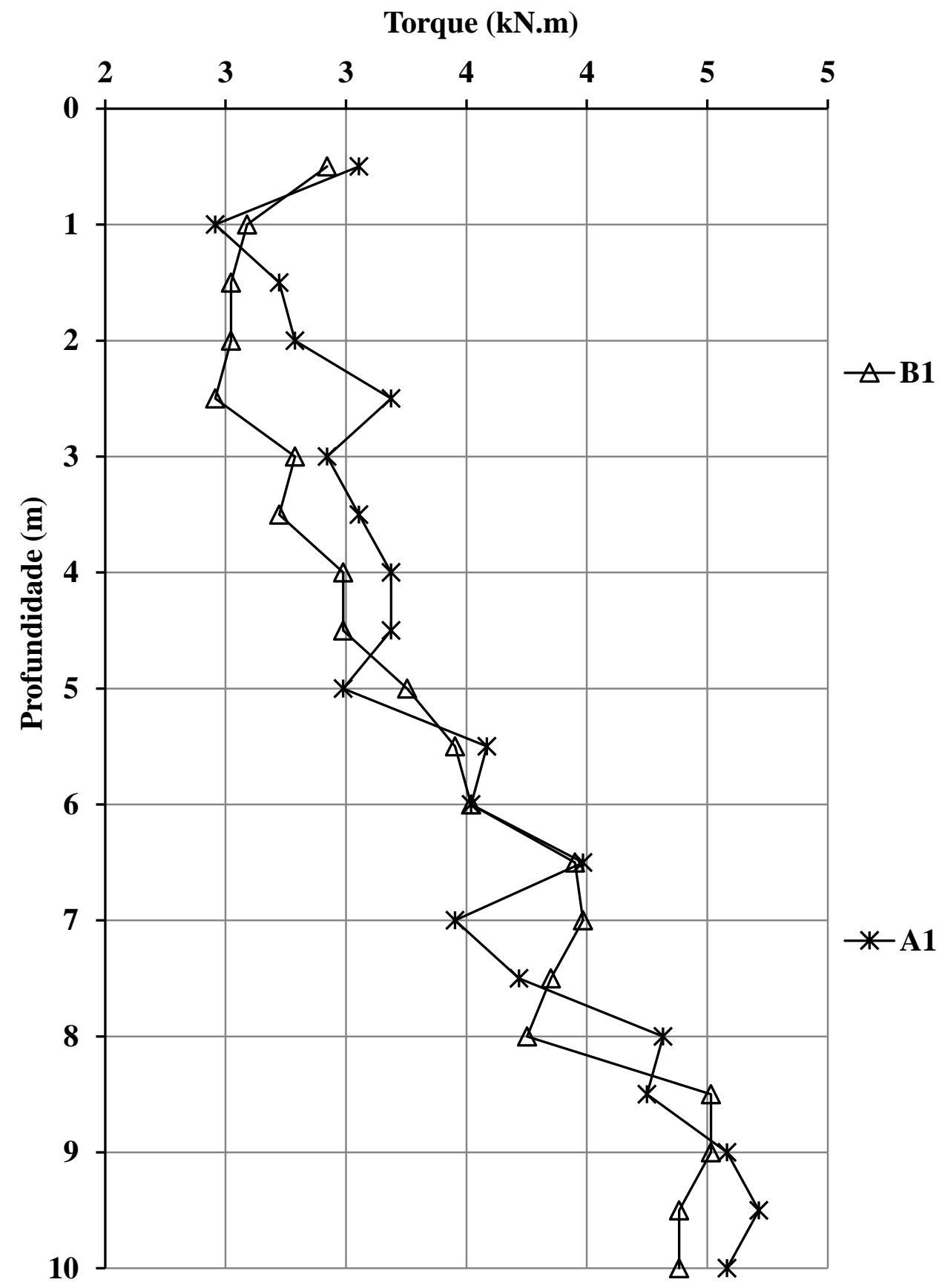

Figura 4.11: Gráficos de comparação entre estaca sem hélice e estaca com uma hélice. 


\section{Torques de Instalação - 2 Hélices}

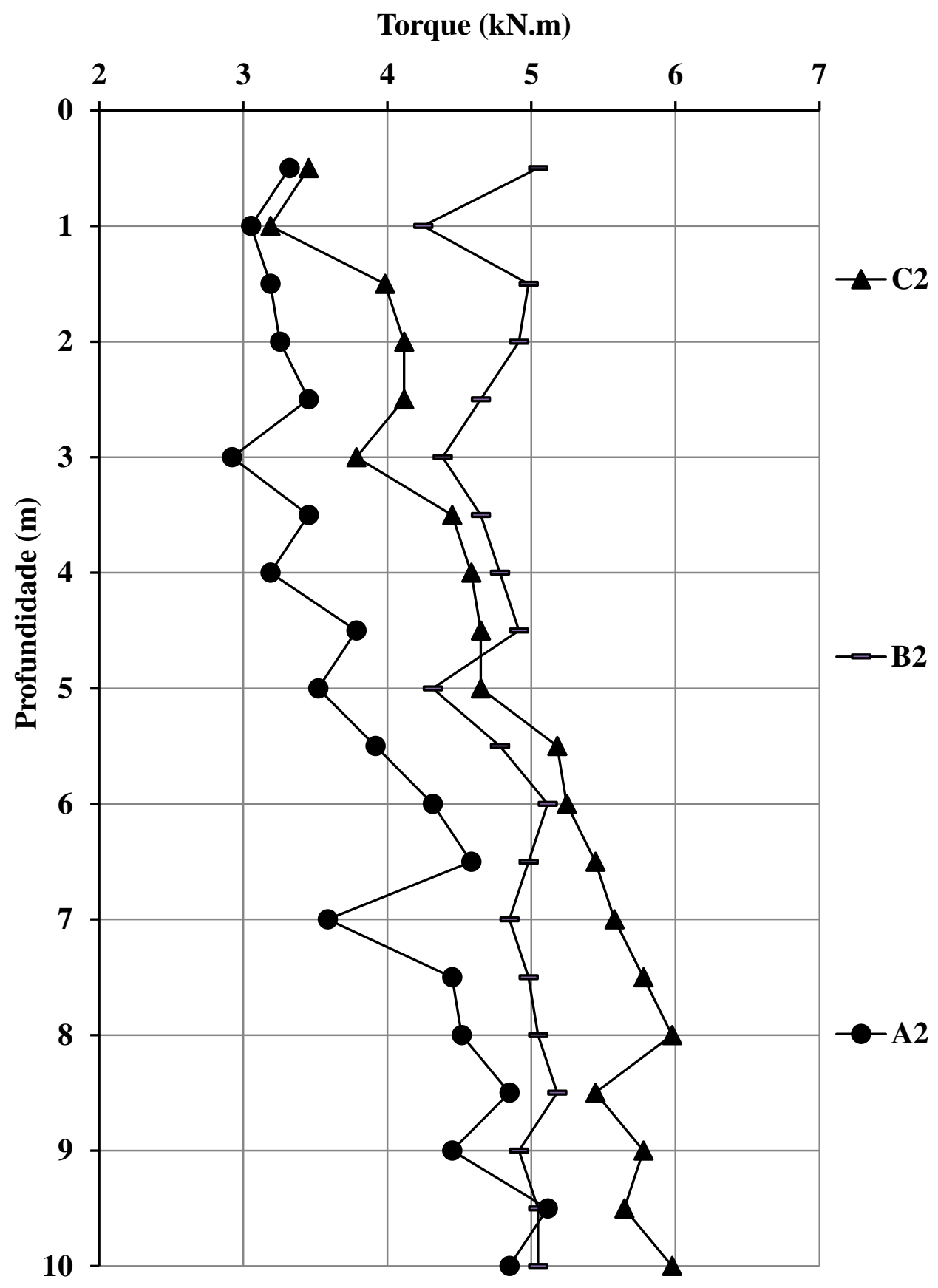

Figura 4.12: Gráficos de comparação entre estaca sem hélice e estaca com duas hélices. 


\section{Torques de Instalação - 3 Hélices}

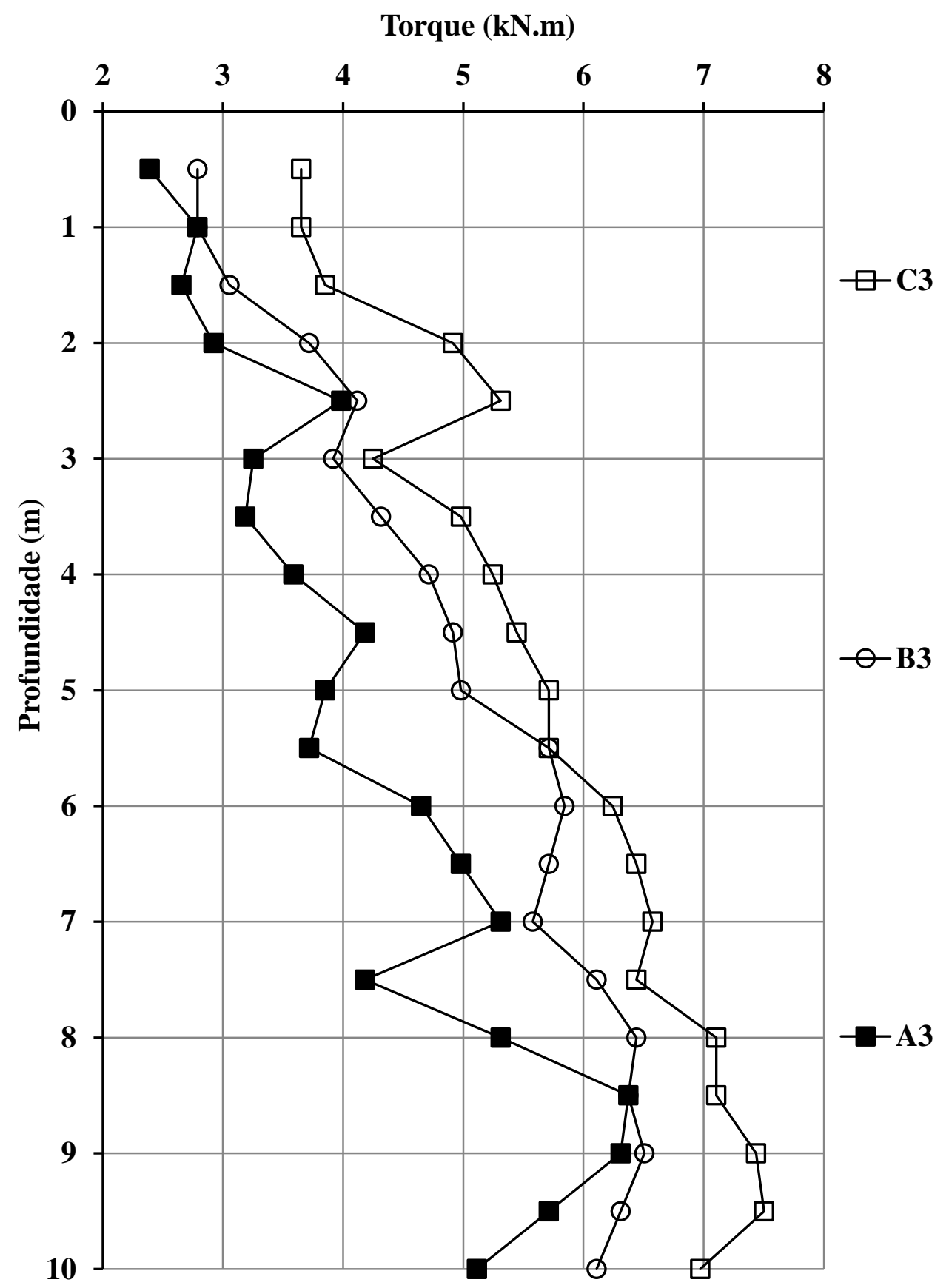

Figura 4.13: Gráficos de comparação entre estaca sem hélice e estaca com três hélices. 


\section{Todas Estacas - Prof. das Hélices (7 a10m)}

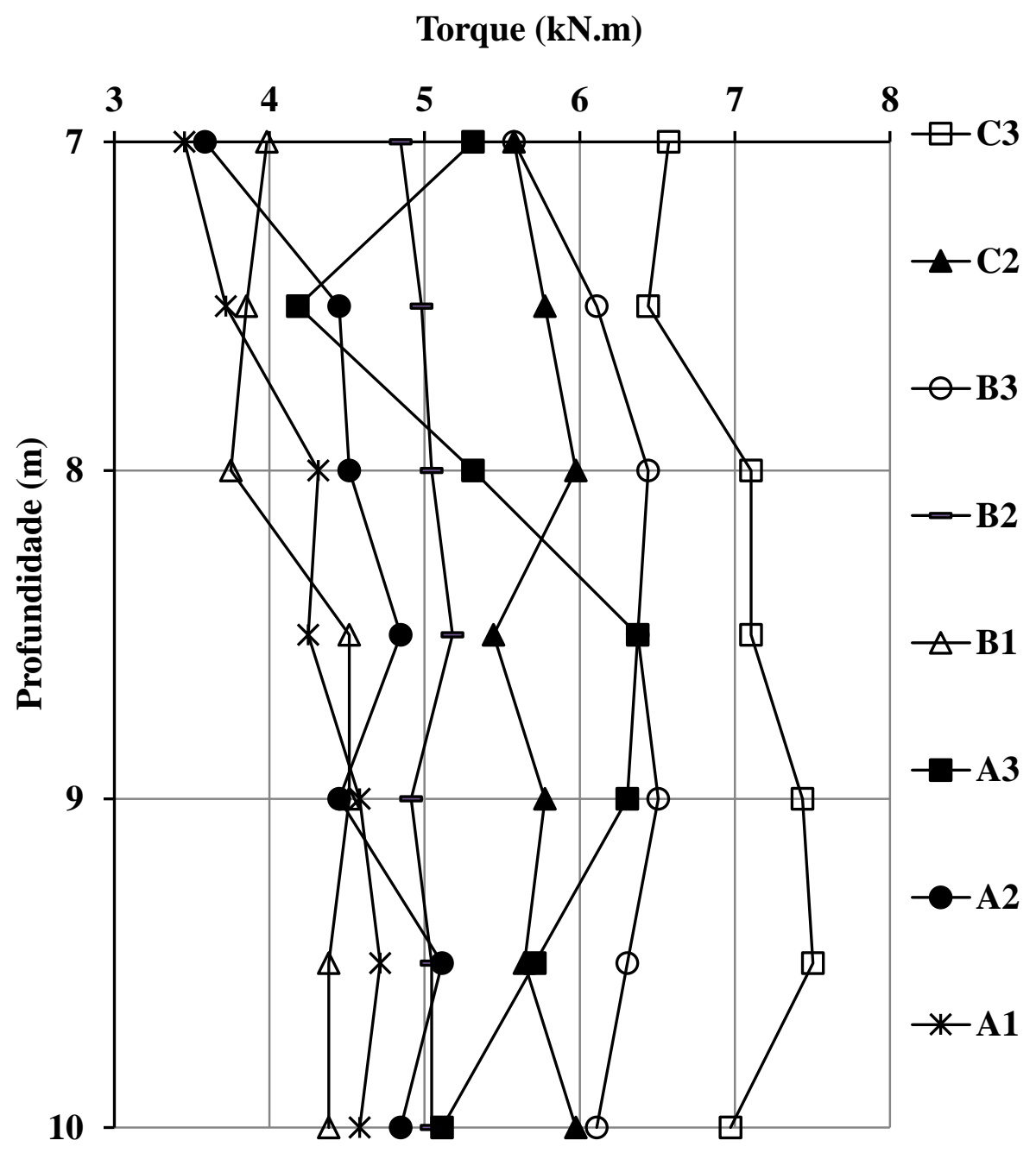

Figura 4.14: Gráficos de comparação entre os torques registrados apenas na camada em que as hélices foram instaladas.

\subsection{CURVAS CARGA X DESLOCAMENTO DOS ENSAIOS DE PROVA DE CARGA À TRAÇÃO}

Os resultados das provas de carga à tração, realizados nas oito estacas helicoidais são mostrados neste item (a estaca $\mathrm{R}$ não é apresentada, pois o resultado do ensaio dela não é representativo do comportamento por atrito das estacas helicoidais, devido ao efeito da instalação e o modo com que a mesma foi instalada). 
Os resultados de capacidade de carga à tração obtidos das interpretações das curvas de prova de carga são apresentados na Tabela 4.7.

Tabela 4.7: Quadro resumo dos resultados capacidade de carga à tração $(\mathrm{Qu})$, de todas as estacas ensaiadas.

\begin{tabular}{|c|c|c|c|}
\hline Estaca & $\begin{array}{c}\text { D médio } \\
(\mathbf{m m})\end{array}$ & D médio $(\mathbf{m m}) / \mathbf{1 0}$ & Qu (kN) \\
\hline $\mathbf{A 1}$ & 200 & 20 & $\mathbf{1 4 , 5}$ \\
\hline $\mathbf{A 2}$ & 200 & 20 & $\mathbf{2 5}$ \\
\hline $\mathbf{A 3}$ & 200 & 20 & $\mathbf{3 6}$ \\
\hline $\mathbf{B 1}$ & 150 & 15 & $\mathbf{1 3 , 5}$ \\
\hline $\mathbf{B 2}$ & 175 & 17,5 & $\mathbf{3 1}$ \\
\hline $\mathbf{B 3}$ & 200 & 20 & $\mathbf{3 9}$ \\
\hline $\mathbf{C 2}$ & 225 & 22,5 & $\mathbf{4 8}$ \\
\hline $\mathbf{C 3}$ & 250 & 25 & $\mathbf{5 7}$ \\
\hline
\end{tabular}

Nos gráficos que se seguem, tem-se as curvas carga x deslocamento vertical disposta da seguinte maneira: na Figura 4.15 são apresentadas todas as curvas de todas as estacas ensaiadas; na Figura 4.16 são apresentadas apenas as estacas Modelo A (com hélices iguais de 200mm de diâmetro); na Figura 4.17 são apresentados o Modelo B (com hélices crescentes de 150 a 200 mm de diâmetro); na Figura 4.18 são apresentados o Modelo C (hélices crescentes entre 200mm e 250mm de diâmetro); na Figura 4.19 são apresentadas as estacas com apenas 1 hélice (A1 e B1); na Figura 4.20 são apresentadas as estacas com 2 hélices (A1 e B1); na Figura 4.21 são apresentadas as estacas com 3 hélices (A3, B3 e C3). 


\section{Provas de Carga - Todas as Estacas}

Carga de Tração (kN)

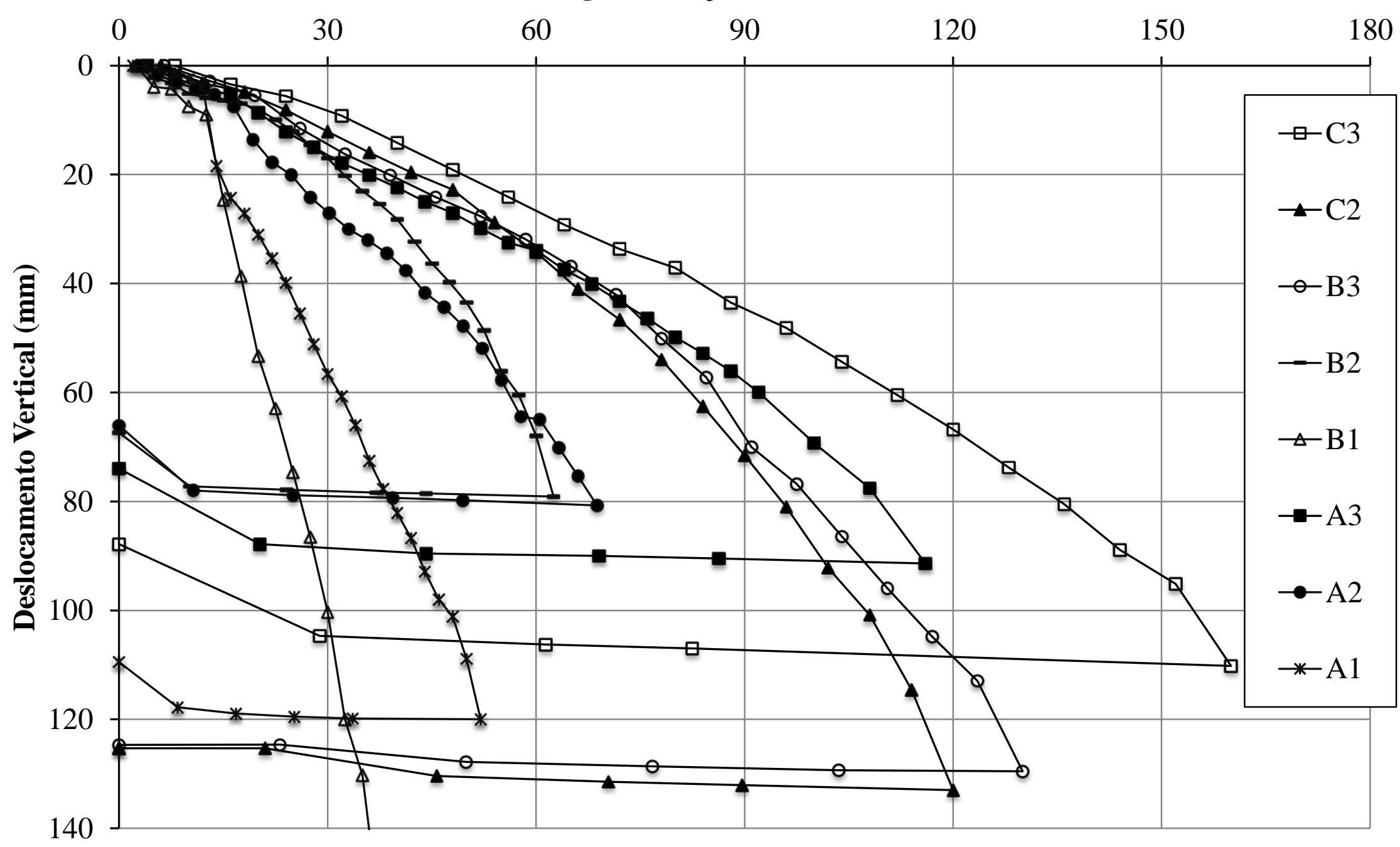

Figura 4.15: Gráfico das curvas Carga vs Deslocamento vertical de todas as provas de carga a tração. 


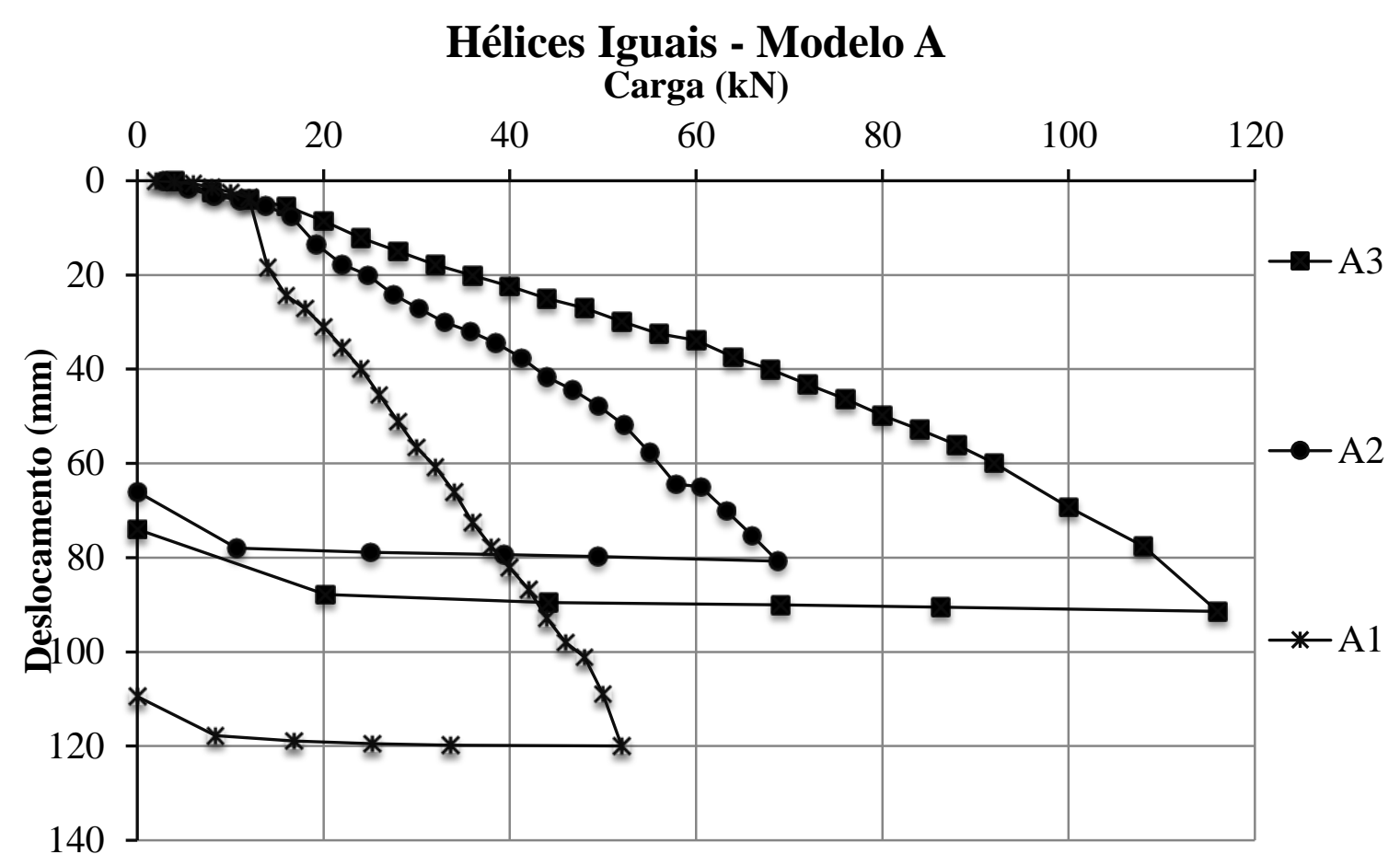

Figura 4.16: Gráfico das curvas Carga vs Deslocamento vertical dos ensaios nas estacas do Modelo A (hélices iguais de 200mm).

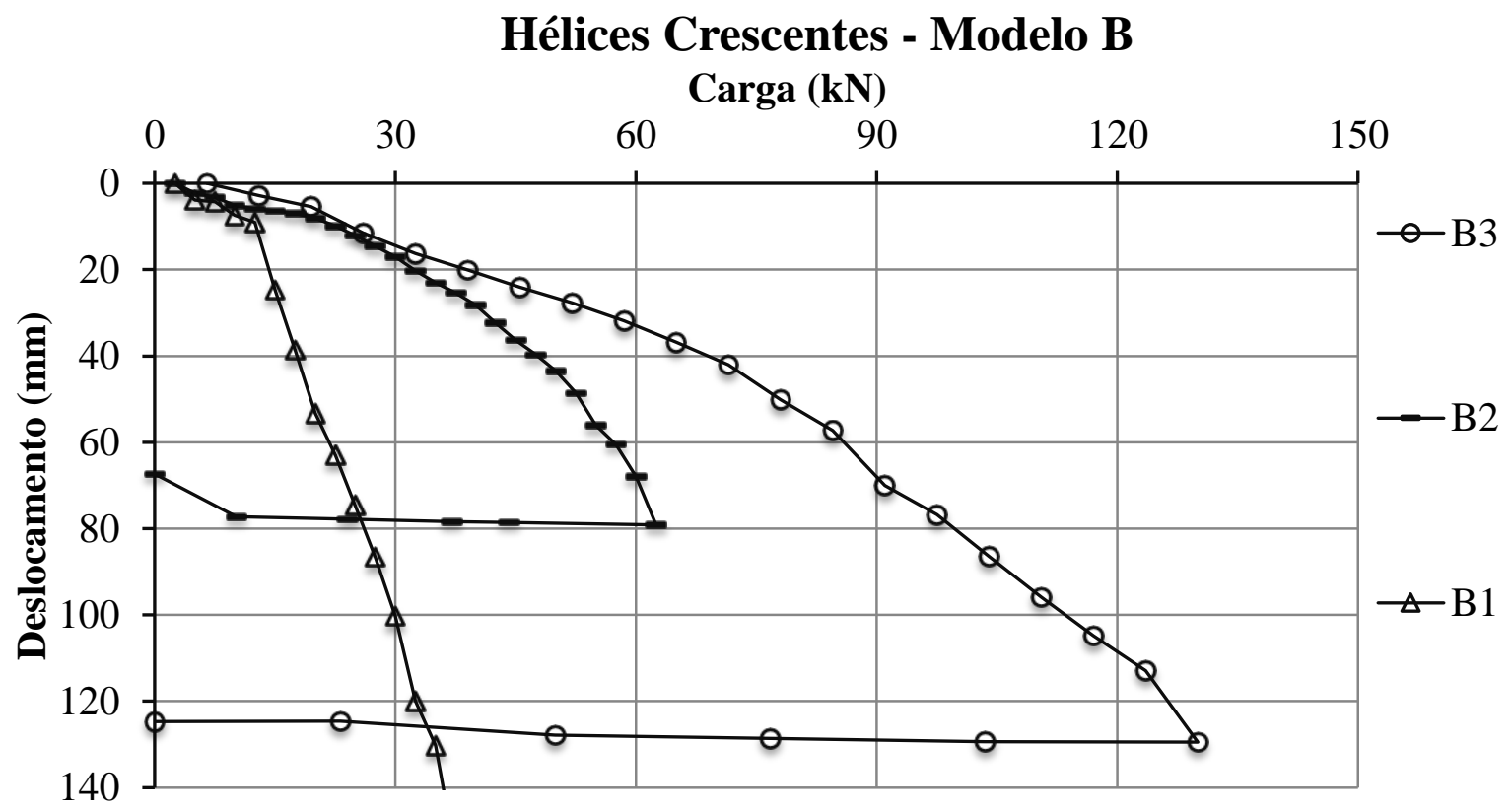

Figura 4.17: Gráfico das curvas Carga vs Deslocamento vertical dos ensaios nas estacas do Modelo B (crescentes entre $150 \mathrm{~mm}$ e $250 \mathrm{~mm}$ ). 


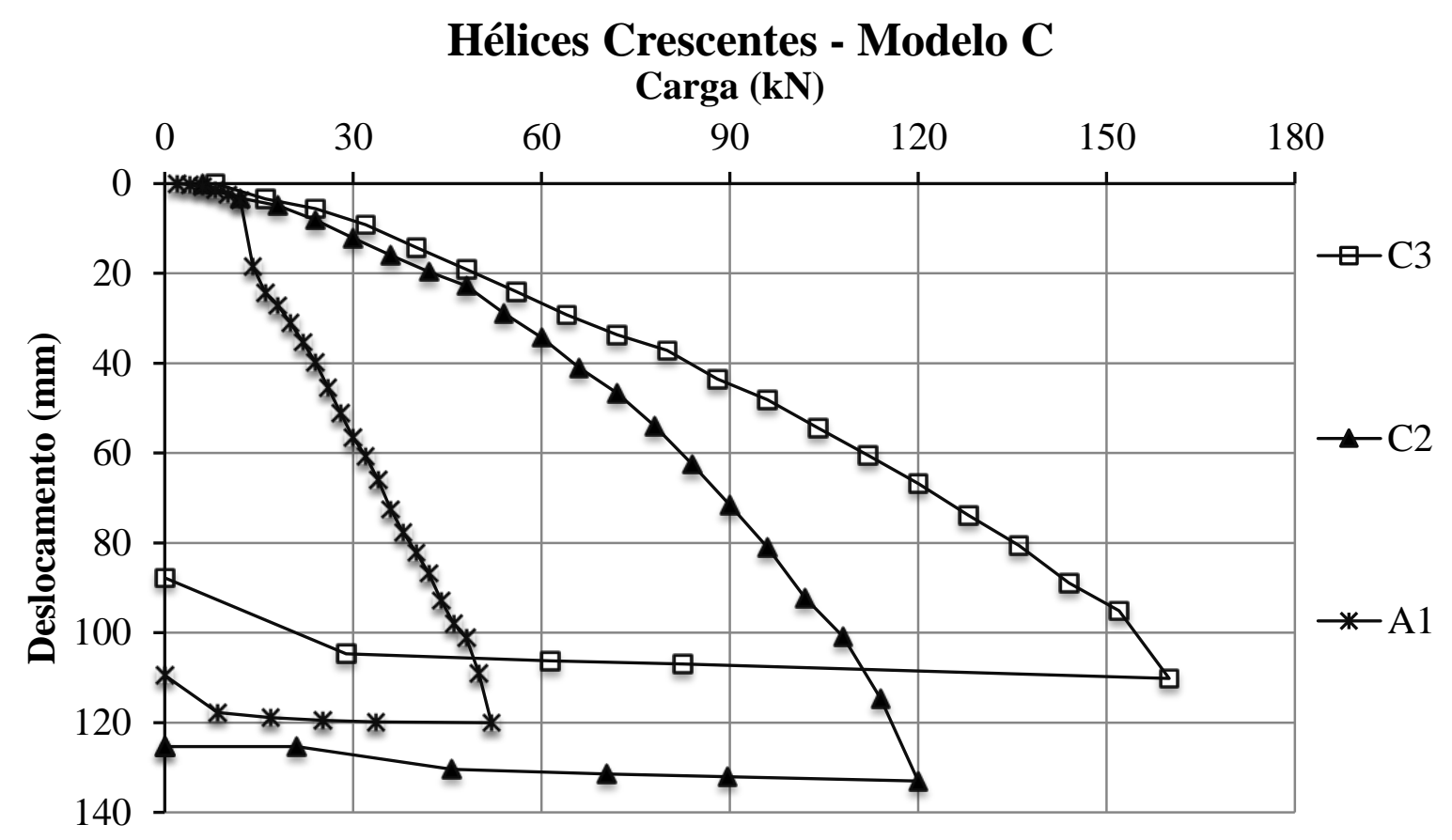

Figura 4.18: Gráfico das curvas Carga vs Deslocamento vertical dos ensaios nas estacas do Modelo C (crescentes entre $200 \mathrm{~mm}$ e $300 \mathrm{~mm}$ )

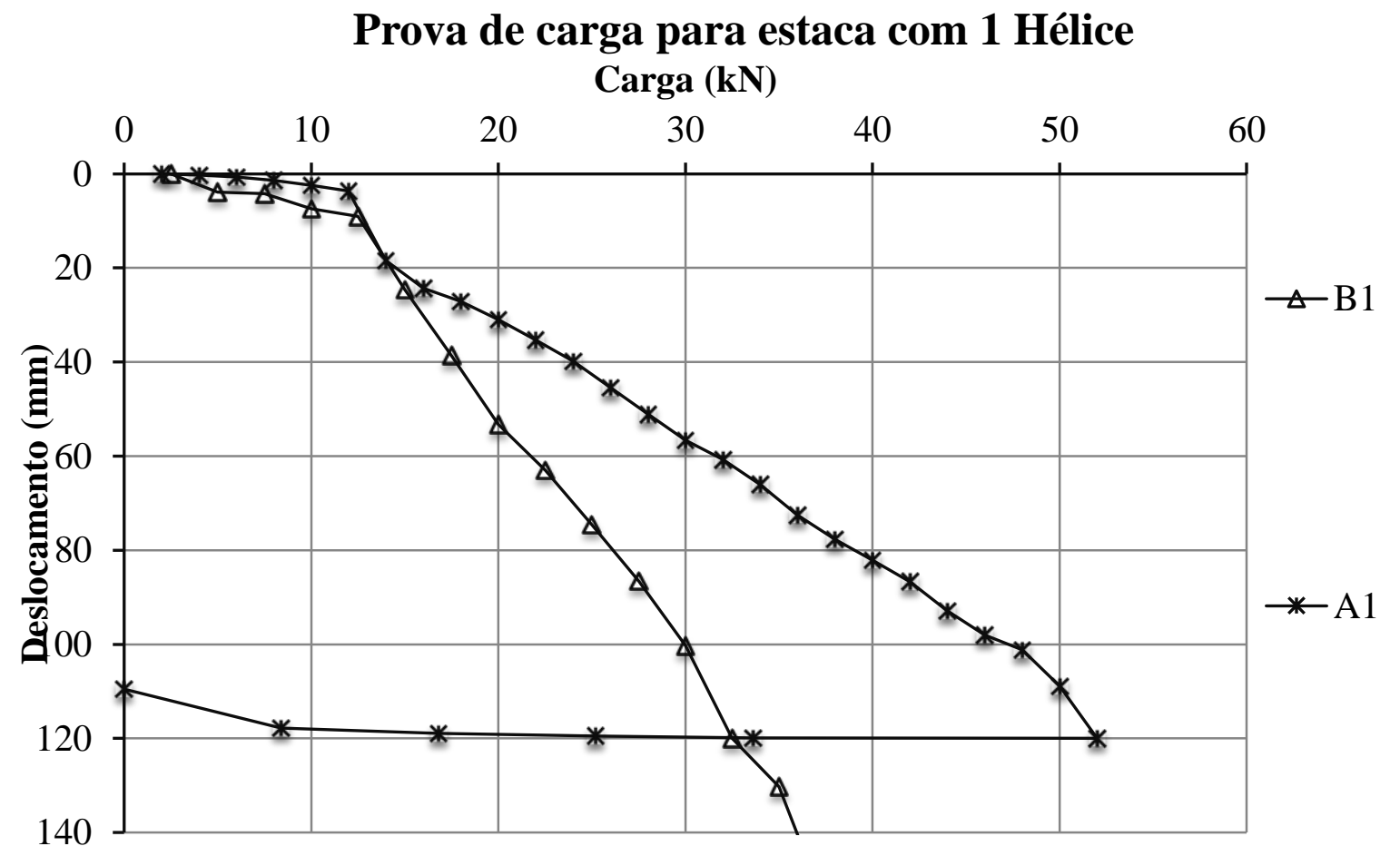

Figura 4.19: Gráfico das curvas Carga vs Deslocamento vertical dos ensaios nas estacas com apenas 1 hélice (B1 com 150mm e A1 com 200mm). 


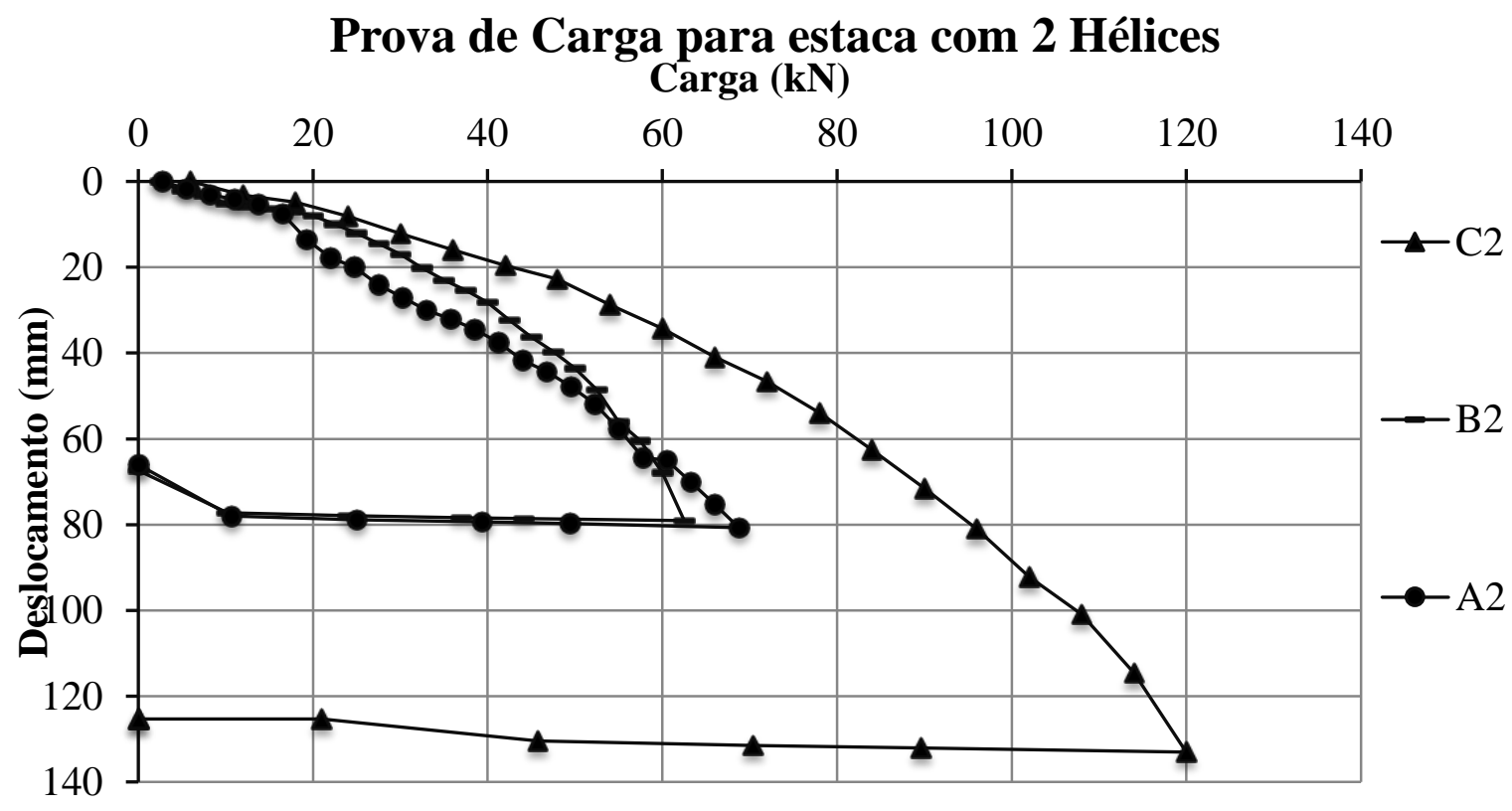

Figura 4.20: Gráfico das curvas Carga vs Deslocamento vertical dos ensaios nas estacas com apenas 2 hélices $(\mathrm{B} 2$ com Dmédio $=175 \mathrm{~mm}$, A2 com Dmédio $=200 \mathrm{~mm}$ e C2 com Dmédio $=225 \mathrm{~mm}$ ).

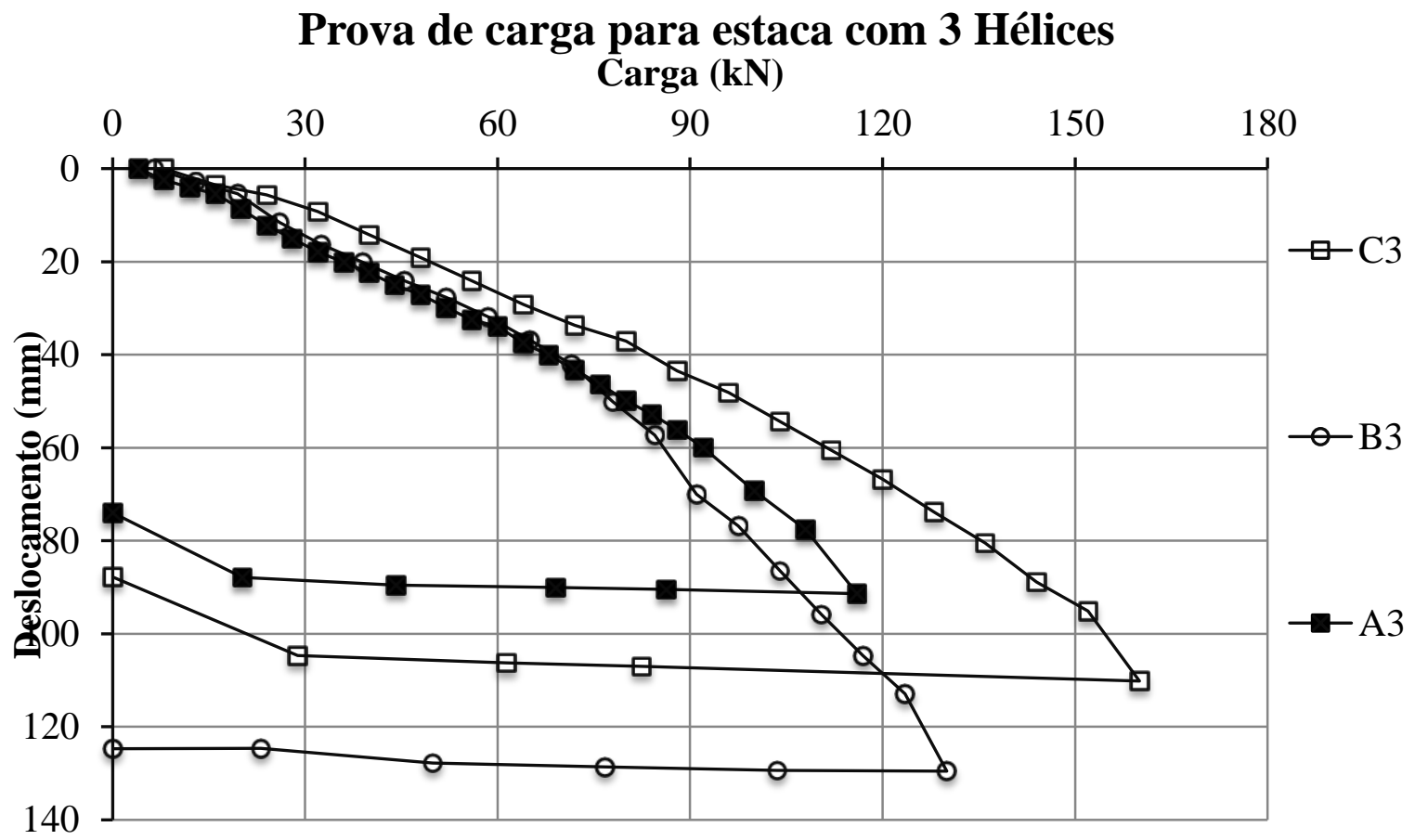

Figura 4.21: Gráfico das curvas Carga vs Deslocamento vertical dos ensaios nas estacas com apenas 3 hélices $($ B3 com Dmédio $=200 \mathrm{~mm}$, A3 com Dmédio $=200 \mathrm{~mm}$ e C3 com Dmédio $=250 \mathrm{~mm}$ ). 


\section{CAPITULO 5 - ～～ANÁLISE DOS RESULTADOS}

Aqui vão as discussões e análises dos resultados encontrados neste trabalho juntamente com comparações com a literatura a respeito das estacas helicoidais.

\subsection{ESTACAS R E O FURO TESTE (F.T.)}

No local do terreno denominado F.T foi realizada a tentativa de instalar e retirar a estaca B1, antes e no local onde seria instalada a estaca R. A intenção inicial foi de após a retirada da estaca B1, se instalar a estaca R e ensaiar a mesma. Deste modo, a prova de carga a tração realizada na estaca $\mathrm{R}$ seria em condições semelhantes de atrito lateral ao de uma estaca helicoidal (com hélice), pois em uma estaca com hélices o solo em volta da haste foi modificado pela instalação das hélices no terreno, e isso muda as condições e propriedades do solo ao redor da haste. Assim, com o resultado de prova de carga na estaca R, seria possível estimar a parcela de resistência por atrito nas demais estacas helicoidais dos ensaios. Deste modo, subtraindo-se da resistência de uma estaca helicoidal o valor de resistência da estaca $\mathrm{R}$, se obteria apenas a parcela de resistência à tração devido à capacidade das hélices.

De fato, não foi possível tal ensaio, pois após a instalação da estaca B1 foi formado o "gap" anteriormente citado na Figura 3.11 que retiraria totalmente o contato da estaca R com o solo, não sendo possível nem sua medição de torque durante a instalação, nem ao menos a prova de carga à tração. A Figura 5.1 apresenta os resultados das leituras de torque na instalação e remoção da estaca B1.

Nota-se na Figura 5.1 na região abaixo de 7 metros (camada onde as hélices das estacas foram instaladas) que o torque de retirada é inferior ao torque de instalação. Este fato mostra que a resistência ao cisalhamento deste solo, medida pelo torque correspondente à penetração da hélice durante a instalação (solo intacto), é superior à resistência deste solo perturbado, medida na retirada da hélice. 
$\mathrm{O}$ resultado de capacidade de carga à tração da estaca $\mathrm{R}$ mostra um valor elevado de resistência por atrito lateral comparando-se com os resultados de capacidade de carga dos outros ensaios em estacas helicoidais. Portanto, este resultado não representativo do fuste de uma estaca helicoidal no mesmo solo.

\section{Torques -Aplicação e Remoção de B1}

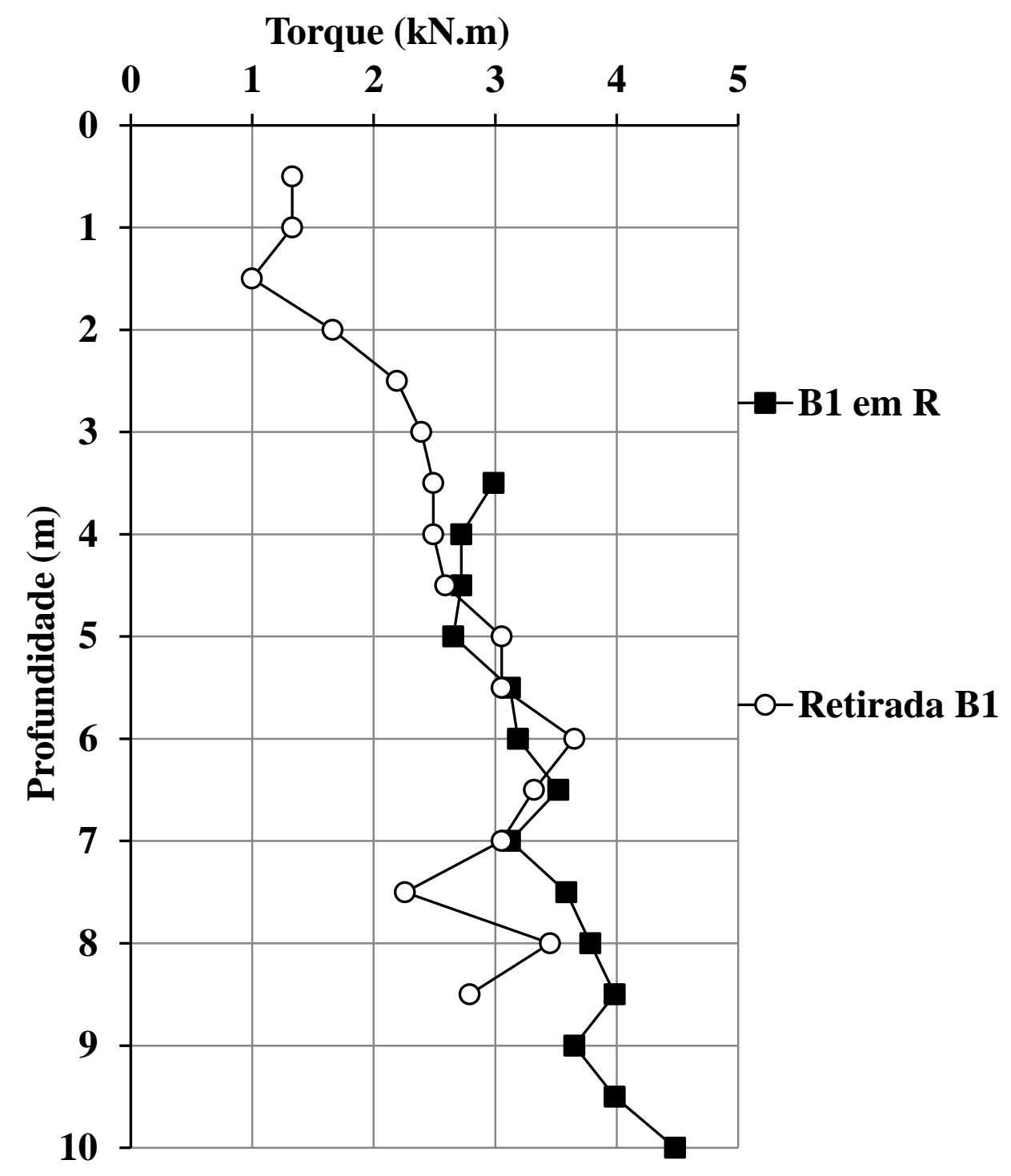

Figura 5.1: Gráfico com os valores registrados de torque na aplicação e remoção da estaca B1, no furo teste.

Maiores diferenças entre antes e depois são notadas na Figura 5.1 abaixo de $7 \mathrm{~m}$ de profundidade, onde o valor de NSPT é maior. 
Nas discussões do trabalho falar sobre o resultado do ensaio da estaca R, que não pode ser usada como comparativo de resistência de atrito lateral na haste para as estacas com hélice, devido ao GAP entre haste e solo. Sendo assim, o valor encontrado para a mesma (R) é superior ao atrito existente na haste quando se possui hélices, pois quando na presença de hélices, o solo se desloca e não fica em contato com a haste. Logo, este é o motivo de não se ter utilizado a estaca $\mathrm{R}$ como referência para separar a parcela de capacidade de carga das hélices nos resultados das provas de carga. No caso da dissertação é coerente considerar que a parcela da haste exerce baixa contribuição da resistência da estaca, se considerar que toda a resistência da estaca com hélice é apenas devido as mesmas, e a subtração de uma com a outra nos levar a conhecer a contribuição de cada hélice.

O objetivo de ensaiar o modelo de estaca $\mathrm{R}$ foi de conhecer separadamente a parcela de capacidade de carga à tração relativa ao atrito lateral na haste da estaca helicoidal. Conhecendose este valor, seria possível conhecer pelos resultados dos ensaios nas estacas helicoidais da Figura 3.15 a contribuição individual de cada hélice na capacidade de carga da estaca.

No entanto, como esta estaca não tinha hélices para desestruturar o solo em torno da haste durante a instalação, os resultados mostram que a capacidade de carga à tração desta não pode ser usada como parcela de resistência de atrito das estacas com hélices. De acordo com os resultados das provas de carga, a resistência à tração da estaca R é superior à da estaca com uma hélice B1. Isto ocorreu porque a resistência por atrito na haste da estaca B1 foi degradada pela instalação da hélice. Este fato ressalta o efeito da instalação na resistência por atrito lateral da estaca.

\subsection{RELAÇÕES ENTRE TORQUE DE INSTALAÇÃO E O ENSAIO SPT}

O torque medido durante a instalação da estaca é utilizado para previsão e controle da capacidade de carga pretendida, conforme exposto no item 2.2 da revisão bibliográfica. Não obstante, foi observada a possibilidade do uso do torque como investigação geotécnica, para obtenção de parâmetros de resistência do solo. 
Os resultados do torque de instalação são dependentes do perfil de solo instalado, pois quão mais resistente ao cisalhamento é o solo, maior será o torque. Ou seja, o torque medido reflete a resistência ao cisalhamento do solo, seguindo o mesmo princípio dos demais métodos de investigação do subsolo que obtêm parâmetros de resistência. Logo, o torque deve ser proporcional aos resultados dos outros métodos de investigação de campo, como por exemplo, o SPT ou CPT.

Com uma vasta campanha de medições de torque durante a instalação das estacas helicoidais em terrenos sondados também por ensaio de simples reconhecimento (SPT), é possível verificar se há alguma correlação entre os dois ensaios. De modo que, assim é avaliado o uso do torque como ensaio de investigação ou reconhecimento do subsolo, não apenas controle de capacidade de carga.

A Tabela 5.1 apresenta o resultado do quociente entre os torques medidos durante a instalação de cada estaca utilizada e o SPT médio, resultado da média entre os $\mathrm{N}_{\mathrm{SPT}} 1,2$ e 3 . Ao mesmo tempo, na Figura 5.2 é apresentado o gráfico em profundidade dos dados da Tabela 5.1.

Tabela 5.1: Tabela de resultados das razões entre Torque de instalação e o $\mathrm{N}_{\mathrm{SPT}}$ médio de SPT1, 2 e 3.

\begin{tabular}{|c|c|c|c|c|c|c|c|c|c|c|c|c|}
\hline \multirow{2}{*}{ Prof (m) } & \multicolumn{10}{c|}{ Torque (kN.m) / SPT Médio } \\
\cline { 2 - 14 } & R & A1 & A2 & A3 & B1 & B2 & B3 & C2 & C3 & \multicolumn{1}{c|}{ B1 em R } & Retirada B1 \\
\hline 1,0 & 1,15 & 1,29 & 1,60 & 1,46 & 1,36 & 2,23 & 1,46 & 1,67 & 1,92 & 0,00 & 0,00 \\
\hline 2,0 & 1,03 & 1,35 & 1,58 & 1,42 & 1,22 & 2,38 & 1,80 & 2,00 & 2,38 & 0,00 & 0,64 \\
\hline 3,0 & 0,94 & 1,21 & 1,21 & 1,35 & 1,16 & 1,82 & 1,63 & 1,57 & 1,77 & 0,00 & 0,41 \\
\hline 4,0 & 0,50 & 0,63 & 0,63 & 0,71 & 0,59 & 0,95 & 0,94 & 0,91 & 1,04 & 0,54 & 0,44 \\
\hline 5,0 & 0,53 & 0,53 & 0,62 & 0,68 & 0,57 & 0,76 & 0,88 & 0,82 & 1,01 & 0,47 & 0,44 \\
\hline 6,0 & 0,51 & 0,56 & 0,68 & 0,73 & 0,56 & 0,81 & 0,92 & 0,83 & 0,99 & 0,50 & 0,41 \\
\hline 7,0 & 0,63 & 0,59 & 0,62 & 0,91 & 0,68 & 0,83 & 0,96 & 0,96 & 1,13 & 0,54 & 0,52 \\
\hline 8,0 & 0,61 & 0,68 & 0,71 & 0,84 & 0,59 & 0,80 & 1,02 & 0,94 & 1,12 & 0,60 & 0,52 \\
\hline 9,0 & 0,61 & 0,64 & 0,62 & 0,88 & 0,63 & 0,68 & 0,91 & 0,80 & 1,03 & 0,51 & 0,31 \\
\hline 10,0 & 0,84 & 0,77 & 0,81 & 0,86 & 0,74 & 0,85 & 1,03 & 1,00 & 1,17 & 0,75 & 0,47 \\
\hline Média & 0,73 & 0,83 & 0,91 & 0,98 & 0,81 & 1,21 & 1,15 & 1,15 & 1,36 & 0,39 & 0,42 \\
\hline
\end{tabular}




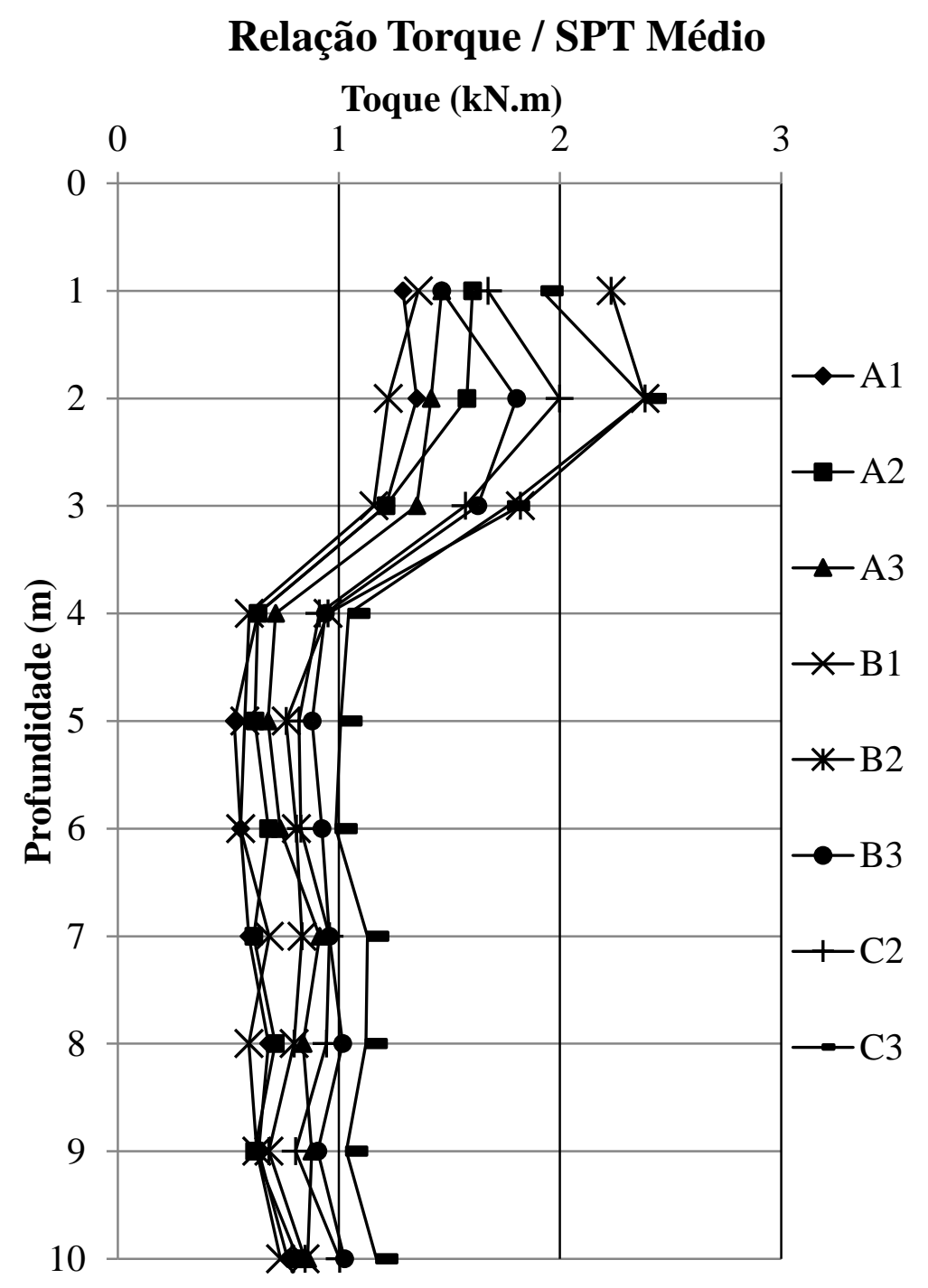

Figura 5.2: Gráfico da relação Torque e SPT médio para todos as estacas.

Os resultados exibidos no gráfico da Figura 5.2 e na Tabela 5.1 mostram que houve uma boa correlação entre os resultados de SPT e torque, pois os resultados de torque foram dispersos e não apresentaram nenhuma tendência, enquanto a relação entre todas as estacas com o SPT foram alinhadas e coerentes até mesmo o perfil de solo. É observada a coerência tanto em níveis de resistência do solo quanto na identificação das camadas.

Quanto aos níveis de resistência, verifica-se que nos primeiros metros onde o SPT apresentou solo mole e transportado esta relação indicou maiores valores devido aos baixos resultados do SPT, e a partir da região onde os $\mathrm{N}_{\text {SPT }}$ foram maiores a relação diminuiu. Ou seja, a relação torque e NSPT foi coerente com os resultados de consistência do solo. 
Quanto ao perfil ou sondagem do subsolo a relação torque e SPT também apresentou coerência por manter uma média nos valores da relação torque e SPT para um mesmo tipo de solo. No solo transportado acima de $4 \mathrm{~m}$ a média da relação foi 1,62, e abaixo na transição de solo transportado para residual e abaixo desta transição no solo residual alterado a relação se manteve em 0,81 .

Tais resultados dão indícios de que é possível correlacionar o SPT e o torque de forma sistemática, encontrado valores de correlação entre os mesmos para uma mesma geometria de estacas, tal como nos resultados de Lutenegger (2011). Pelos resultados aqui encontrados esta relação pode ser função da granulometria do solo e da resistência ao cisalhamento do mesmo. No entanto, são poucos os resultados de torque e SPT deste trabalho, e seria necessário maior número de resultados de SPT e torque em solos variados para uma apropriada averiguação destas tendências e confirmação de uma real correlação entre estes ensaios.

Por fim, fica esta ideia para futuras pesquisas. Pois a possibilidade de uso do próprio torque de instalação da estaca como investigação de solo gera economia, considerando que ao mesmo tempo é controlada a instalação e qualidade da estaca e confirmado o perfil de solo sondado exatamente no ponto de instalação. Este uso seria um ganho para a prática das estacas helicoidais.

\subsection{ANALISE dOS MÉTOdOS DE PREVISÃo DE CAPACIDADE DE CARGA À TRAÇÃo}

Na presente investigação o espaçamento entre as hélices $(900 \mathrm{~mm})$ é igual a três vezes o diâmetro da maior hélice $(300 \mathrm{~mm})$ e mais de três vezes dos valores dos diâmetros das demais hélices dos modelos testados. Logo, o espaçamento relativo entre hélices de todas as estacas é maior que $3(\mathrm{~S} / \mathrm{D} \geq 3$ ) e conforme Lutenegger (2011) estas estacas possuem alta eficiência (acima de 90\%) e segundo Hoyte e Clemence (1985) se comportariam pelo modo de ruptura de cargas individuais. 
Seguindo recomendações de Perko e Rupiper. (2000) foram utilizados os dois métodos de previsão indicados para os projetos das estacas. Os resultados de capacidade de carga obtidos pelos métodos citados acima, e medidos nos ensaios, são apresentados na Tabela 5.2.

Tabela 5.2: Valores estimados e medidos da capacidade de carga à tração das estacas ensaiadas

\begin{tabular}{cccccc}
\hline Estaca & $\begin{array}{c}\text { Método 1 } \\
\text { (cap. de carga } \\
\text { individual), kN }\end{array}$ & $\begin{array}{c}\text { Método 2 } \\
\text { (ruptura } \\
\text { cilíndrica), kN }\end{array}$ & $\begin{array}{c}\text { Valor medido } \\
\text { Qu, (kN) }\end{array}$ & $\begin{array}{c}\text { Método 1 } \\
\text { (Qu medido/ } \\
\text { Qu calculado) }\end{array}$ & $\begin{array}{c}\text { Método 2 } \\
\text { (Qu medido/ } \\
\text { Qu calculado) }\end{array}$ \\
\hline A1 & 37 & 62 & 14,5 & 0,39 & 0,23 \\
A2 & 71 & 70 & 25 & 0,35 & 0,36 \\
A3 & 71 & 74 & 36 & 0,51 & 0,49 \\
B1 & 21 & 51 & 13,5 & 0,64 & 0,26 \\
B2 & 55 & 68 & 31 & 0,56 & 0,46 \\
B3 & 106 & 85 & 39 & 0,37 & 0,46 \\
C2 & 91 & 85 & 48 & 0,53 & 0,56 \\
C3 & 161 & 106 & 57 & 0,35 & 0,54 \\
\hline & & Media & 0,46 & 0,42 \\
& & Coeficiente & 0,22 & 0,27 \\
\hline
\end{tabular}

Para as estimativas de capacidade de carga mostradas na Tabela 5.2 foram utilizados os parâmetros de solo estimados por meio de correlações com os valores de $\mathrm{N}_{\text {SPT }}$ na profundidade das hélices. Pelos resultados, nota-se que os valores de capacidade de carga à tração estimados para as estacas helicoidais neste tipo de solo, que perde grande parte de sua resistência após a instalação das hélices, foram bem superiores aos valores medidos (em média 2,17 vezes).

As previsões da Tabela 5.2 foram feitas com nos parâmetros do solo intacto, e não do solo perturbado pós instalação. Isso pode ser explicação da discrepância na comparação entre valores medidos e previstos de capacidade de carga. Sendo assim, os parâmetros de SPT utilizados diretamente nas previsões não foram adequados para este caso, o que mostra a necessidade de conversão ou fator que corrija os dados do solo intacto para considerar a perturbação.

Como pode ser visto na Tabela 5.2 as razões entre o medido e o previsto para o método de capacidades de carga individuais possui menor coeficiente de variação (método 1, CV=22\%) do que para o método de ruptura cilíndrica (método 2, CV=27\%). Observa-se também na Tabela 5.3 
que a contribuição das hélices superiores à capacidade de carga é melhor prevista através do método das capacidades individuais (Método 1). Esta implicação já era esperada, visto que pelo Método 2, como mostra a Tabela 5.2, a capacidade de carga das estacas com apenas uma hélice é superior a medida e a prevista pelo Método 1. Estes resultados condizem com Lutenegger (2011) a respeito do método de capacidade de cargas individuais traduzir melhor o comportamento destas estacas ensaiadas devido $\mathrm{S} / \mathrm{D} \geq 3$.

Tabela 5.3: Valores medidos (prova de carga) e previstos das parcelas de contribuição das hélices superiores das estacas ensaiadas (estacas com duas ou três hélices)

\begin{tabular}{c|ccc|ccc}
\hline \multirow{2}{*}{ Estaca } & \multicolumn{3}{|c|}{ Contribuição da $\mathbf{2}^{\mathbf{a}}$ hélice (\%) } & \multicolumn{3}{c}{ Contribuição da 3 $\mathbf{3}^{\mathbf{a}}$ hélice (\%) } \\
\cline { 2 - 6 } & $\begin{array}{c}\text { Medida, } \\
\mathrm{kN}\end{array}$ & $\begin{array}{c}\text { Prevista Método } \\
\text { 1 (cap. de carga } \\
\text { individual), } \mathrm{kN}\end{array}$ & $\begin{array}{c}\text { Prevista Método } \\
\text { 2 (ruptura } \\
\text { cilíndrica), } \mathrm{kN}\end{array}$ & $\begin{array}{c}\text { Medida, } \\
\mathrm{kN}\end{array}$ & $\begin{array}{c}\text { Prevista Método } \\
\text { 1 (cap. de carga } \\
\text { individual), kN }\end{array}$ & $\begin{array}{c}\text { Prevista Método } \\
\text { 2 (ruptura } \\
\text { cilíndrica), kN }\end{array}$ \\
\hline A2 & 42.0 & 47.9 & 11.4 & - & - & - \\
A3 & 29.2 & 33.7 & 5.4 & 30.6 & 29.7 & 5.4 \\
B2 & 56.5 & 61.8 & 25.0 & - & - & - \\
B3 & 44.9 & 32.1 & 20.0 & 20.5 & 48.1 & - \\
C2 & 69.8 & 59.3 & 27.1 & - & - & - \\
C3 & 58.8 & 33.5 & 21.7 & 15.8 & 43.5 & 19.8 \\
\hline
\end{tabular}

As parcelas de capacidade de carga à tração de cada hélice na Tabela 5.3 é determinada pela metodologia apresentada em Tsuha e Aoki (2010).

Além disso, os resultados foram semelhantes a Tsuha et al (2007) onde a contribuição das hélices inferiores foram maiores que a das hélices superiores e, a adição de uma segunda hélice no Método 2 não contribuiu de forma significativa com a capacidade de carga, já que a resistência ao cisalhamento da superfície cilíndrica de solo formada entre as duas hélices é baixa (solo de $\mathrm{N}_{\text {SPT }}$ baixo). Resultado coerente com Lutenegger (2011).

\subsubsection{RETROANÁLISE}

Uma retroanálise realizada através do método de capacidades individuais, utilizando os parâmetros do solo iniciais obtidos com o SPT antes da instalação das estacas foi realizada. Reduziram-se os parâmetros de ângulo de atrito e coesão do solo até que o resultado do método convergisse para os resultados medidos através de prova de carga à tração, ou seja, realizada 


\section{4}

redução dos parâmetros para que os resultados encontrados na segunda coluna da Tabela 5.2 se aproximassem ao máximo dos resultados da quarta coluna da mesma tabela. Segue os resultados da retroanálise na Tabela 5.4.

Tabela 5.4: Percentagem de redução dos parâmetros do solo obtidos através de retroanálise pelo método das capacidades de carga individuais.

\begin{tabular}{ccc}
\multicolumn{3}{c}{ Retroanálise } \\
\hline \multirow{2}{*}{$\begin{array}{c}\text { Redução dos } \\
\text { parâmetros }\end{array}$} & Ângulo de atrito & Coesão \\
\cline { 2 - 3 } & $10 \%$ & $90 \%$ \\
\hline
\end{tabular}

Por ser um solo onde sua resistência é pautada na coesão aparente (devido a sua "estrutura") ao passar da hélice, grande parte desta coesão é reduzida. No entanto, esta retroanálise pode não ser a mais adequada para se medir a real perda de parâmetros de resistência do solo com a instalação devido as reduções serem induzidas de modo iterativo e não com base no comportamento do solo. O mais adequado seria medir esta perda de resistência dos parâmetros através de ensaios de laboratório, ensaio triaxial, de amostras indeformadas retiradas diretamente acima das hélices e comparar com as prováveis perdas em relação ao também necessário ensaio triaxial fora da área de influência de instalação das hélices (também são necessários ensaios fora da área de influência, pois todos os parâmetros foram determinados indiretamente através de correlações com os ensaios de campo).

Portanto, para se determinar um índice de redução dos parâmetros mecânicos do solo, deve-se realizar mais ensaios de laboratório, ensaios triaxiais, antes e depois da instalação, verificando a influência da consistência/compacidade do solo e do diâmetro da hélice nestes parâmetros. E para melhorias nos métodos de previsão de capacidade de carga deve-se realizar retroanálise para se estimar quais seriam os fatores de capacidade de carga e coeficiente de empuxo na carga última adequados aos solos tropicais. Tais análises não foram realizadas neste trabalho e ficam como recomendações para trabalhos futuros. 


\subsection{USO DO CPT PARA AVALIAÇÃO DO EFEITO DE INSTALAÇÃO NO SOLO ACIMA DAS HÉLICES}

Este item apresenta uma análise do efeito da instalação das estacas helicoidais na camada de solo acima das hélices das estacas por meio de ensaios CPT. Para tanto, um conjunto de ensaios CPT foi realizado próximo às estacas helicoidais (9 ensaios - Tabela 4.4), e o outro conjunto foi realizado mais distante da área de influência das estacas (distância maior que 3 vezes o diâmetro da maior hélice).

As distâncias entre eixos do ensaio CPT próximo as estacas são variáveis devido ao estado do furo em questão, onde haviam estacas que formavam maior vazio em seu redor do que outras ("gap" apresentado na Figura 3.11b), sendo deste modo impossibilitada a realização de ensaios mais próximos do eixo da estaca e com distâncias uniformes.

O efeito da instalação das estacas no solo foi analisado comparando as resistências de ponta qc ou atrito lateral fs destes dois grupos de ensaios CPT (próximos e distantes das estacas). Os resultados comparativos de qc, antes e depois da instalação são mostrados na Figura 5.3 e os resultados de atrito lateral são apresentados nas Figuras 5.4 e 5.5. 


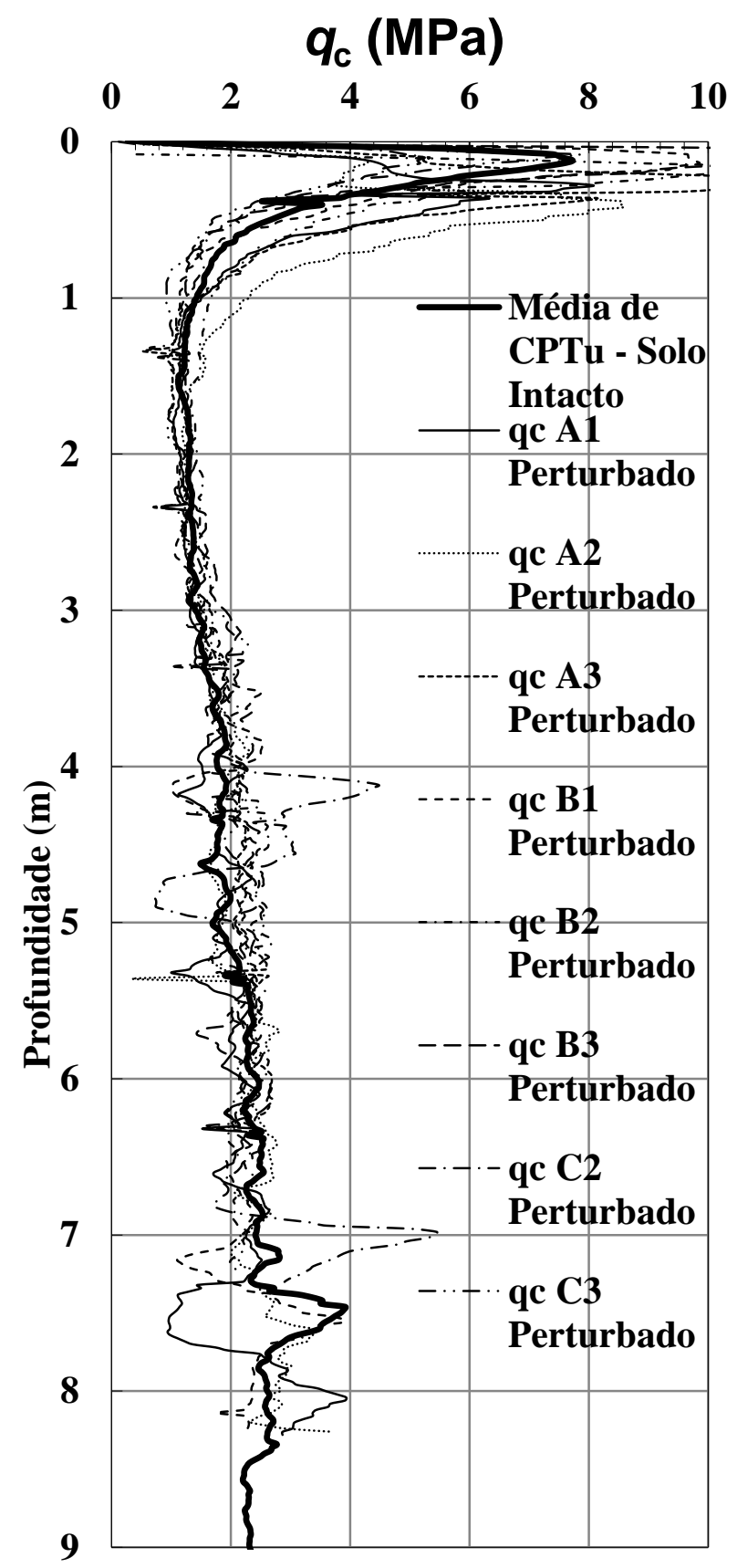

Figura 5.3: Resistencia de ponta (qc) de todos os ensaios CPT (executados próximos e distantes das estacas).

Os ensaios CPT realizados próximos às estacas, conduzidos para avaliar o efeito da instalação, foram até as profundidades acima das hélices de modo a não influenciar posteriormente os resultados das provas de carga. As profundidades finais dos ensaios de cone em solo perturbado ficaram com cerca de $1 \mathrm{~m}$ acima da hélice do topo de cada estaca. Estas profundidades variaram de acordo com o número de hélices, pois quanto maior o número de 
hélices menos profundos eram os ensaios (profundidade final de 6,5 a 8,2 m - Figura 5.3). Os ensaios CPT realizados acima das hélices das estacas com três hélices (estacas A3, B3 e C3) foram excluídos desta análise por representar os resultados da camada superior do perfil (primeiros 6,5 $\mathrm{m}$ de profundidade) de solo transportado poroso e que possui baixa resistência ( $\mathrm{N}_{\mathrm{SPT}}$ entre 2 e 5). Portanto, nesta análise foram usados apenas os resultados que chegaram a profundidades entre 7,2 e $8,2 \mathrm{~m}$.

A Figura 5.3 indica que os dados de qc não foram afetados pelo efeito de instalação no solo que cercam as estacas. Provavelmente isto se deve a baixa resistência do solo testado e a sensibilidade do equipamento utilizado não ter sido adequada. O cone CPT (elétrico) utilizado consegue captar medidas de qc até $50 \mathrm{MPa}$, e os níveis de qc medidos na camada em análise foram entre 2 e $4 \mathrm{MPa}$.

Por outro lado, os resultados de atrito lateral (fs) nos ensaios realizados próximos às estacas foram inferiores aos resultados dos ensaios realizados longe da área de influência das estacas. Foi possível notar maiores diferenças de fs em maior profundidade, principalmente a partir da transição do solo tropical transportado para o solo residual (a partir de cerca de $7 \mathrm{~m}$ ) nas Figura 5.4 e Figura 5.5, pois o solo residual estruturado possui maiores níveis de resistência. Este fato pode ser observado em todas as figuras (Figura 5.4 e Figura 5.5) que mostram fs, no entanto, devido a variabilidade e aos poucos ensaios realizados nesta pesquisa é preciso mais testes para confirmar este comportamento.

As perdas de resistência são maiores em solos mais resistentes devido a desestruturação do solo com a passagem das hélices e em solo pouco resistentes as perdas são menores, tal como ocorre em Tsuha et al (2007) e Tsuha et al (2012). 


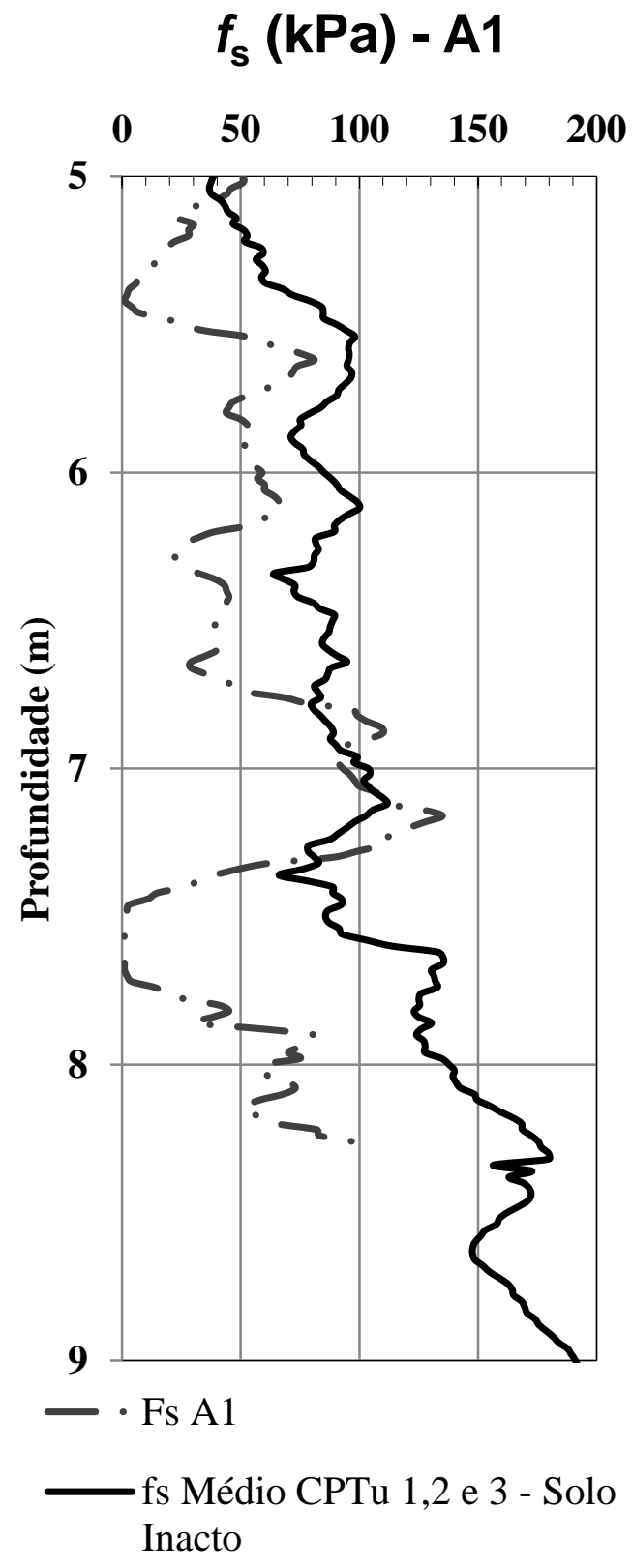

(a)

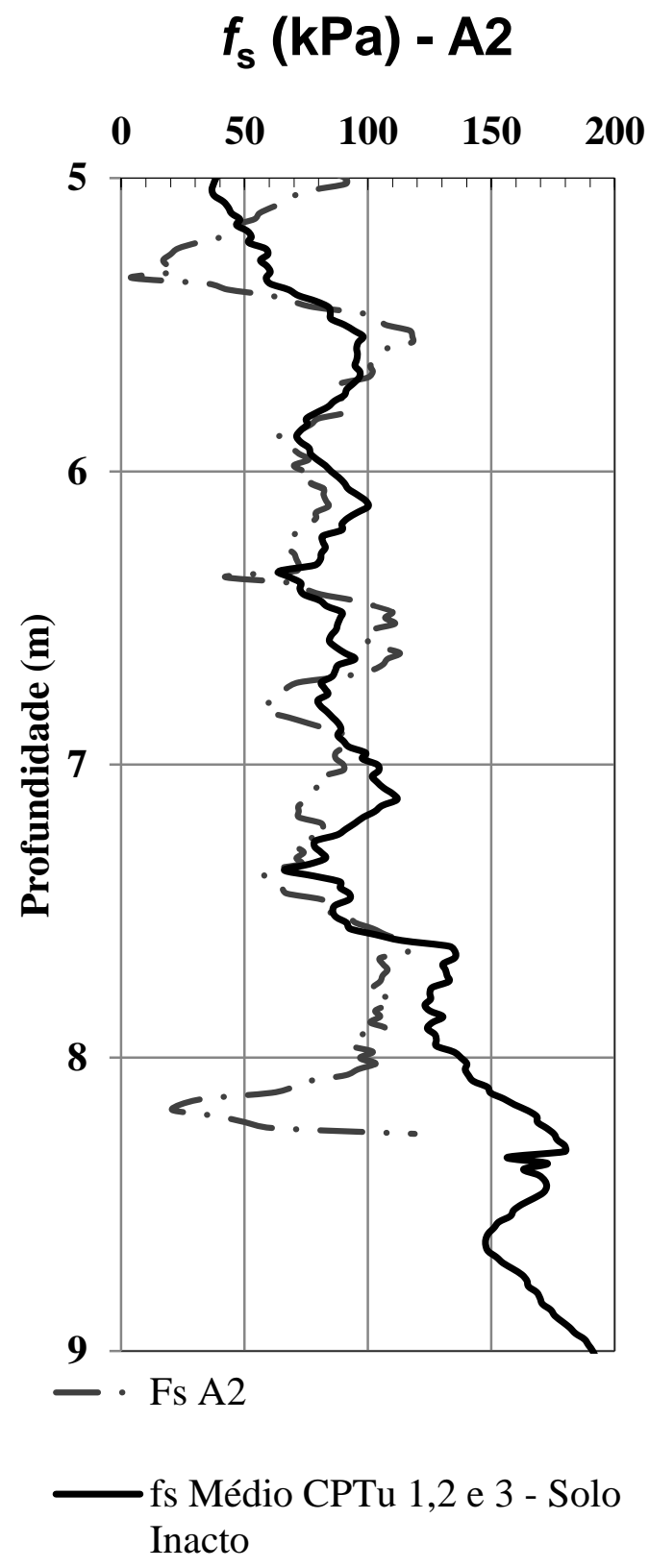

(b)

Figura 5.4: Comparação entre os valores de fs próximos as estacas do Modelo e a média entre dos valores de fs dos ensaios CPT 1, 2 e3. 


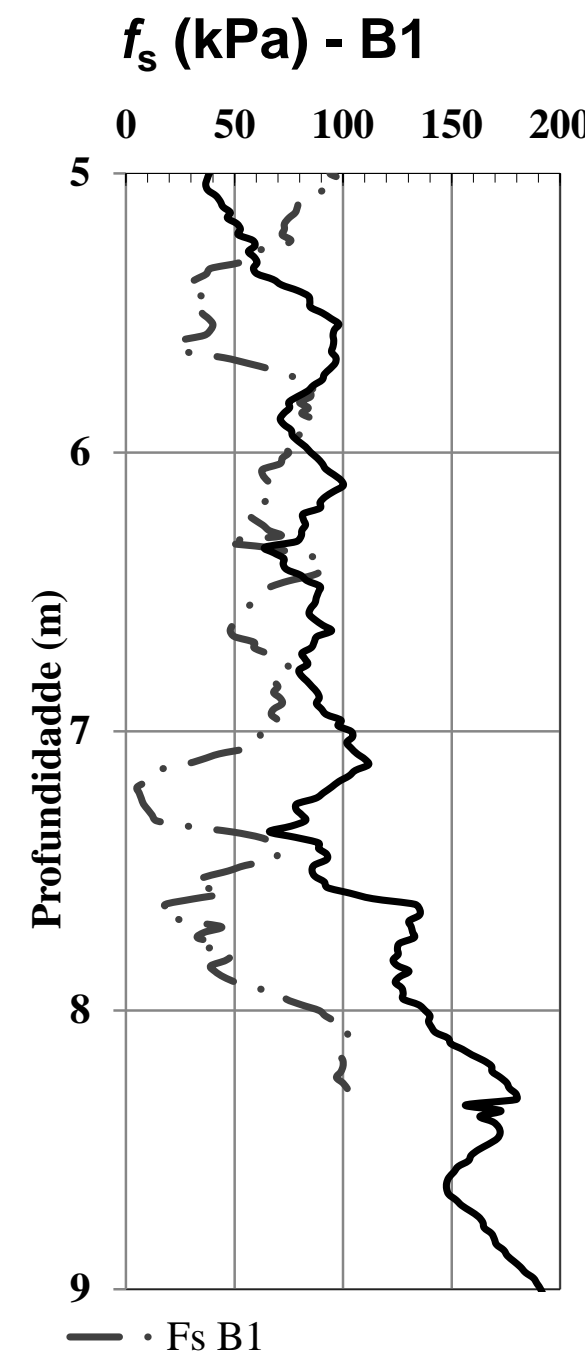

— fs Médio CPTu 1,2 e 3 Solo Inacto

(a) $f_{s}(k P a)-B 2$
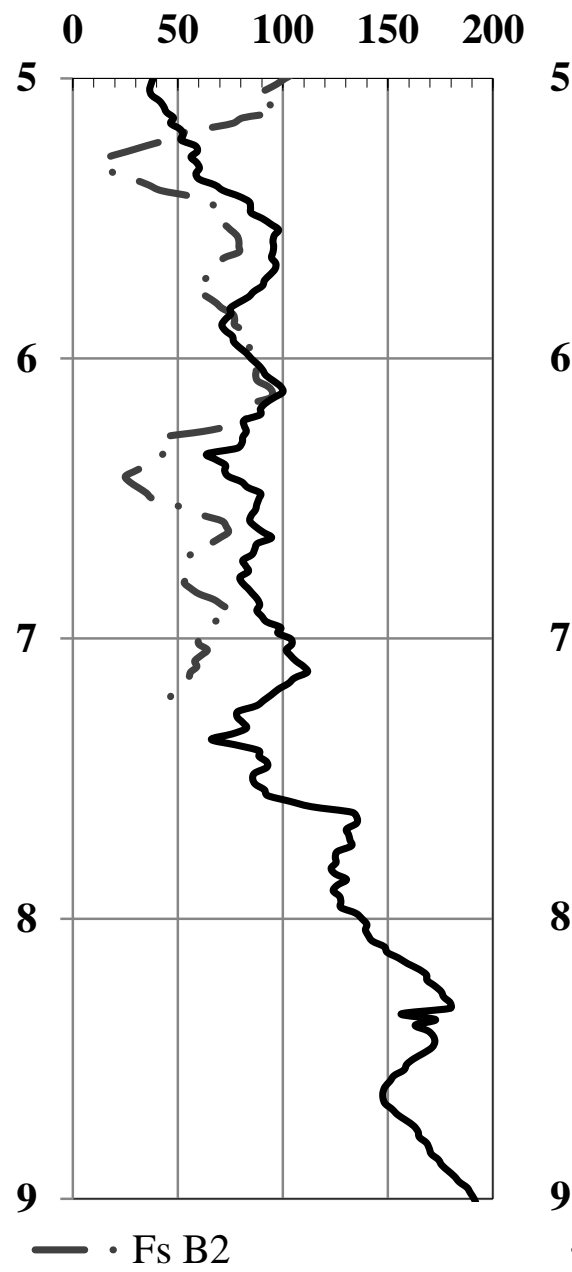

fs Médio CPTu 1,2 e 3 Solo Inacto

(b)

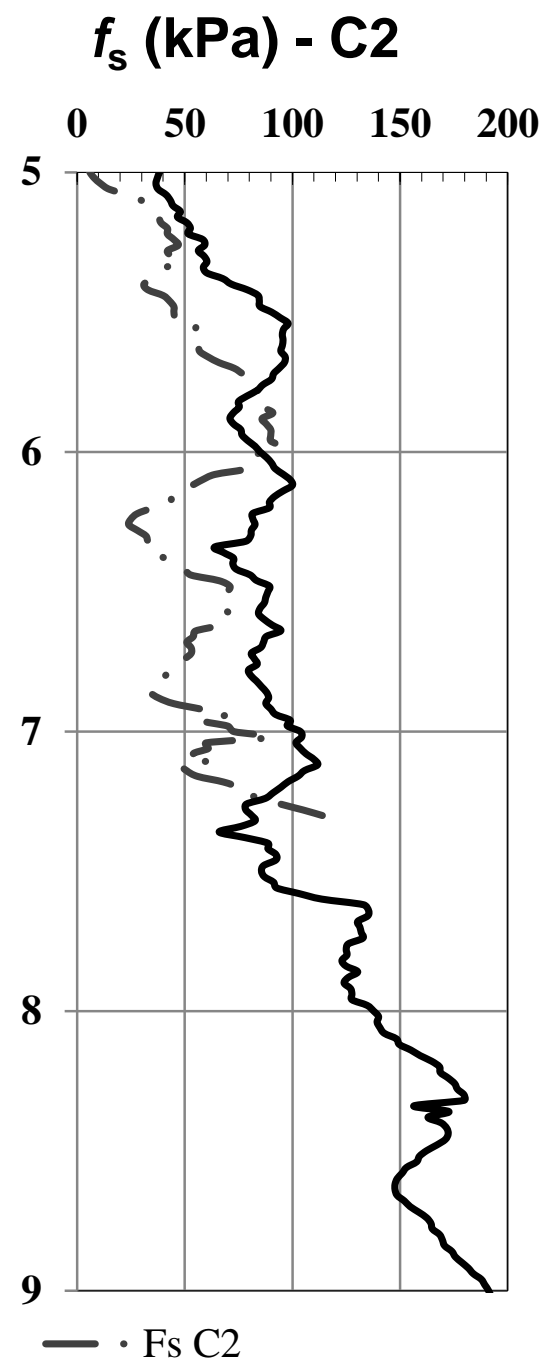

fs Médio CPTu 1,2 e 3 Solo Inacto

(c)

Figura 5.5: Comparação entre os valores de fs próximos as estacas do Modelo B e C e a média entre os valores de fs dos ensaios CPT 1, 2 e3.

Apresenta-se a Figura 5.4 e Figura 5.5 apenas entre 5 e $9 \mathrm{~m}$ de profundidade (com o índice $\mathrm{N}_{\text {SPT }}$ entre 6 e 9 golpes $/ 30 \mathrm{~cm}$ ) porque a resistência de cisalhamento da camada de solo superior (até $5 \mathrm{~m}$ de profundidade) é baixa. Com os resultados obtidos para este solo tropical poroso e estruturado de baixa resistência é possível obter-se apenas conclusões qualitativas a respeito da influência da instalação das hélices da estaca no solo: o procedimento de instalação perturba o solo dentro da região cilíndrica ao redor e acima das hélices, e consequentemente provoca decréscimo dos parâmetros de resistência em volta da instalação. 
Por fim, conforme discutido em toda esta seção, foi possível através do ensaio CPT avaliar qualitativamente a perda de resistência devido ao processo de instalação das estacas no solo apenas por meio do parâmetro fs. A resistência de ponta qc não foi sensível às variações de comportamento do solo devido a instalação, fato devido a baixa resistência do solo e do equipamento não estar adequadamente dimensionado.

Conclui-se também que nos solos lateríticos de baixa resistência a instalação tem um efeito de decréscimo da resistência por atrito lateral entre solo/haste e, portanto, influencia na parcela de resistência por atrito/aderência na haste e a parcela de cisalhamento do solo acima das hélices da capacidade de carga à tração da estaca helicoidal.

Para melhores previsões do efeito da instalação nos parâmetros de resistência do solo afim de ajustar os métodos de cálculo desta estaca é preciso realizar mais ensaios em diferentes tipos de solos com equipamentos de sensibilidade adequada.

\subsection{EFEITO DA CONFIGURAÇÃO DAS HÉLICES NO TORQUE E CAPACIDADE DE CARGA À TRAÇÃO}

Para a análise do efeito da configuração das hélices, tanto no torque de instalação quanto na capacidade de carga, é preciso primeiro compreender o fenômeno físico de instalação da estaca e suas consequências na propriedade do solo. Este efeito da instalação está ilustrado, em resumo, pelas Figura 5.6 e Figura 5.7. 


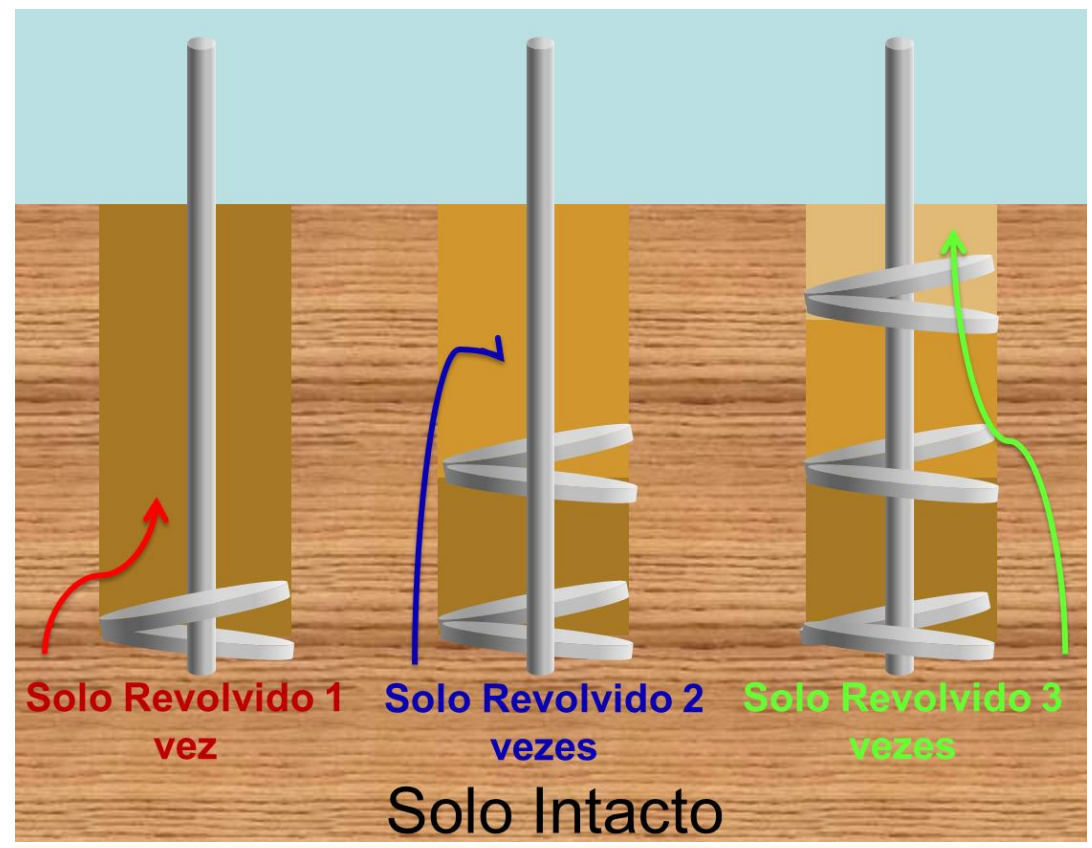

Figura 5.6: Efeito de instalação da estaca metálica helicoidal cilíndrica (hélices de igual diâmetro).

O efeito da passagem da hélice no solo após a instalação de uma estaca de configuração cilíndrica, onde as hélices são todas de mesmo diâmetro, como mostra a Figura 5.6, ocorre da seguinte forma:

- No caso da estaca com somente uma hélice, após a passagem desta hélice o solo acima da mesma é perturbado ("revolvido") apenas uma vez, ou seja, ele foi cortado, deslocado e modificado "uma" vez em relação ao estado intacto inicial do solo.

- $\quad$ Para a estaca com duas hélices iguais, a primeira hélice continuaria a perturbar o solo intacto abaixo, no entanto, a segunda hélice passaria na mesma massa de solo perturbada pela primeira hélice, devido ao fato delas possuírem o mesmo diâmetro. Portanto, todo o solo acima da segunda hélice seria duas vezes "modificado" em relação ao estado intacto inicial do solo.

- $\quad$ No caso de uma estaca com três hélices de mesmo diâmetro, usando-se a mesma lógica da estaca com duas hélices, o solo acima da terceira hélice seria três vezes cortado, deslocado e alterado em relação ao estado inicial do solo e, além disso, a terceira hélice passaria na mesma massa de solo que tanto a primeira quanto a segunda hélice passaram. 
- Logo, este raciocínio pode ser aplicado para todas as estacas de configuração cilíndrica com quatro hélices ou mais. Ou seja, para qualquer estaca cilíndrica com n hélices, acima da enésima hélice terá sempre o solo alterado $\mathrm{n}$ vezes, pois os diâmetros das $\mathrm{n}$ hélices possuem a mesma projeção, o que faz com que as $n$ hélices cortem o mesmo solo.

No caso de estacas helicoidais multi-hélices com configuração cônica, o fenômeno de perturbação do solo durante o processo de instalação ocorre de maneira distinta, e o mesmo está esquematizado na Figura 5.7.

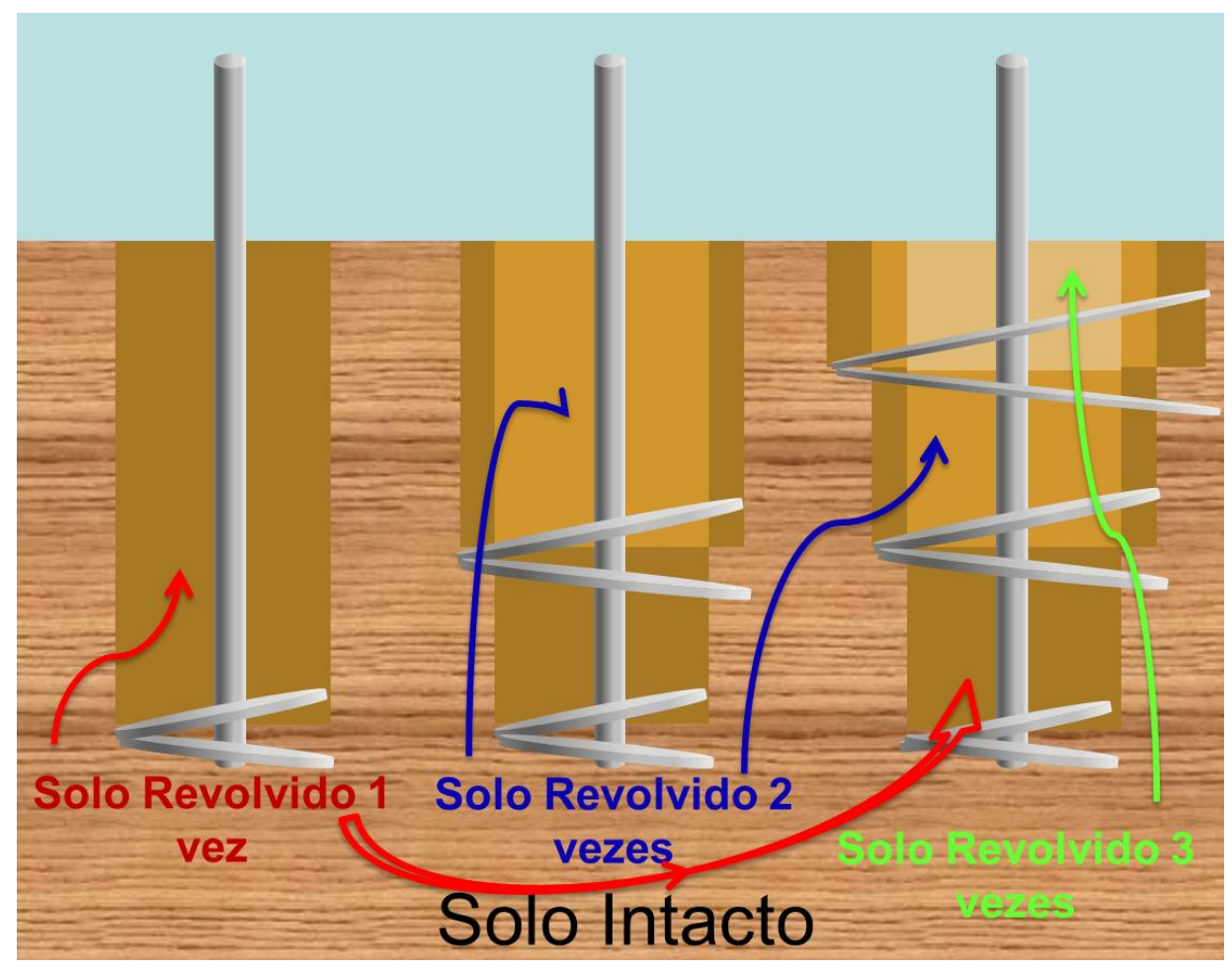

Figura 5.7: Hipótese de perturbação do solo após a instalação de estaca helicoidal cônica (com hélices crescentes).

A Figura 5.7 ilustra o efeito de instalação da estaca helicoidal no caso em que a configuração das hélices é cônica. Ou seja, os diâmetros das hélices são distintos e crescentes (da ponta para o topo da estaca). E com maiores detalhes, temos:

- $\quad$ No caso de uma estaca com apenas uma hélice, por não ter diferença com o primeiro caso da Figura 5.6 também se chega à mesma conclusão, que o solo acima da primeira hélice fica alterado uma vez em relação ao estado inicial do solo, intacto. 
- Para a estaca helicoidal de configuração cônica de duas hélices, as hélices são diferentes, onde a segunda hélice (ainda não instalada) possui maior diâmetro em relação a primeira hélice (já instalada). Isso faz com que ao se instalar a segunda hélice ela atravesse tanto uma região de solo previamente alterado (equivalente ao diâmetro da primeira hélice já instalada) quanto uma região de solo ainda no estado inicial imperturbado, solo intacto. Sendo assim, acima da segunda hélice encontram-se regiões de solo modificado duas vezes (uma vez pela primeira hélice e a segunda vez pela segunda hélice), mas também modificado apenas uma vez (região fora da área de projeção da primeira hélice).

- No caso da estaca de configuração cônica com três hélices, análogo ao fenômeno que ocorre na segunda hélice de uma estaca de duas hélices, ocorre também na terceira hélice deste caso. A terceira hélice, por ser maior que a segunda, vai cortar um solo já alterado duas vezes (pela passagem da primeira e da segunda hélice) correspondente a área de projeção da primeira hélice, também irá cortar um solo já alterado apenas uma vez (pela segunda hélice, na área de fora da projeção da primeira hélice) e por fim, também cortará uma região em solo no seu estado inicial, imperturbado. Sendo assim, acima da terceira hélice, haverá massa de solo em três estados distintos de perturbação, região alterada três, duas e apenas uma vez.

- Logo, analogamente, o efeito de instalação de estaca helicoidal de configuração cônica de três hélices pode ser estendido para quatro hélices ou mais, de maneira que uma estaca cônica de $n$ hélices, terá acima da enésima hélice, $n$ estados de perturbação do solo, variando de solo apenas modificado uma vez até modificado n vezes após sua instalação.

Após esta análise do fenômeno físico de perturbação do solo causada pela passagem das hélices das estacas, para duas diferentes configurações de hélices (cilíndrica e cônica), é possível compreender os resultados obtidos pelas medidas de torque de instalação, e nos ensaios de provas de carga a tração das estacas.

\subsubsection{EFEITO DA CONFIGURAÇÃO DAS HÉLICES NO TORQUE DE INSTALAÇÃO}

Para analisar o efeito da configuração das hélices nos resultados de torque necessário para a instalação das estacas, são comparados os resultados das instalações do modelo A3 (configuração cilíndrica) com os resultados das instalações do Modelo B3 (configuração cônica). 


\section{4}

Foram comparados estes modelos de estacas de três hélices, porque ambos têm o mesmo diâmetro médio de hélices, evitando-se que as diferenças dos torques medidos sejam associadas a acréscimos de diâmetros. Na Figura 5.8 são comparados os gráficos de torque de instalação ao longo da profundidade, obtidos pela instalação das estacas A3 e B3 (mesmo Dmédio = $200 \mathrm{~mm}$ ).

Os resultados ilustrados na Figura 5.8 mostram que o valore de torque medido ao final de instalação na estaca cônica (B3) é $20 \%$ maior que na estaca cilíndrica (A3) (torque final de instalação em B3 igual 6,11 kN.m e em A3 igual 5,11 kN.m). No entanto, as duas estacas de três hélices possuem o mesmo diâmetro médio de $200 \mathrm{~mm}$. Este comportamento reflete o efeito de instalação apresentado nas Figura 5.6 e Figura 5.7 e levam a conclusão de que estacas de configurações cônicas necessitam de maiores torques do que as de configurações cilíndricas. Este resultado foi semelhante ao encontrado por Rupiper (1976) apud Ghaly et al (1991) que encontrou $25 \%$ de diferença entre os torques de estacas cônicas e cilíndricas.

As parcelas de torque associadas à instalação da segunda e terceira hélices da estaca B3(cônica) podem ser tão elevadas quanto da primeira hélice, e a soma das parcelas de torque referentes às últimas duas hélices elevam o valor de torque para instalar a estaca B3. No caso da configuração cilíndrica (A3) todas as três hélices cortam a mesma projeção de solo, ou seja, apenas a primeira hélice corta o terreno natural e necessita de maiores torques, as demais cortam um solo inteiramente alterado, diminuindo torques necessários a segunda e terceira hélice.

Portanto, comparando-se B3 com A3, B3 exige maiores torques a sua instalação, superando o fato de que a primeira hélice de B3 (150mm) é menor que a primeira hélice de A3 (200mm). Justifica-se assim, a diferença de torque requerido para instalar estacas de mesmo Dmédio e configurações distintas.Comportamento condizente com a Figura 5.6. 


\section{Torques de Instalação - A3 x B3}

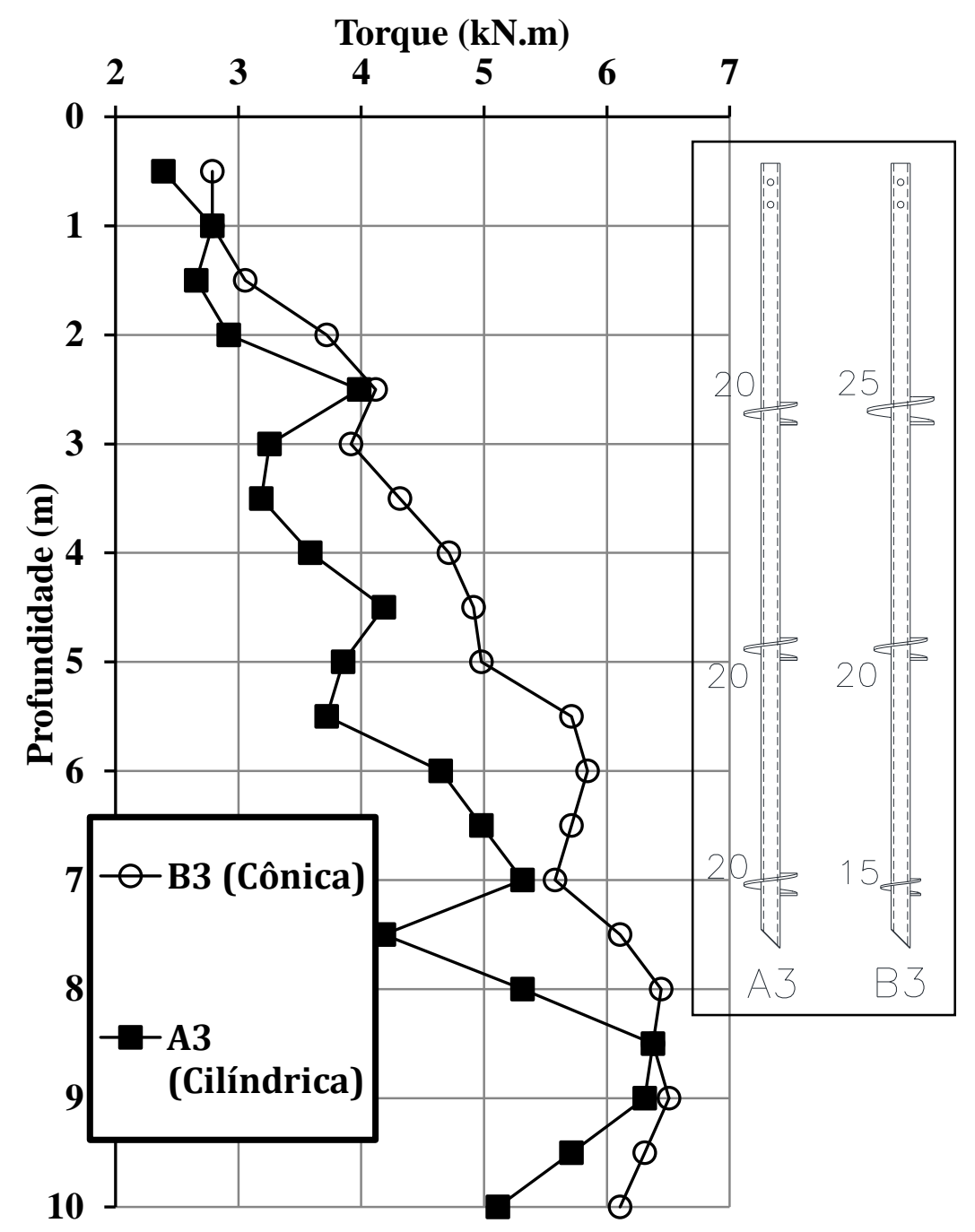

Figura 5.8: Comparação das curvas de torque de instalação versus profundidade entre as estacas A3 e B3.

Como mostra a Figura 5.9 de Tsuha e Aoki (2010), o torque necessário para instalar a estaca no terreno é dividida em duas parcelas, uma resistida pelo atrito lateral na haste (Ts, que costuma ser pequena, devido a prévia passagem da hélice na região de solo ao longo da haste), e a outra necessária para avançar as hélices (Th) no subsolo, que é a somatória dos torques necessário para instalar cada hélice. 


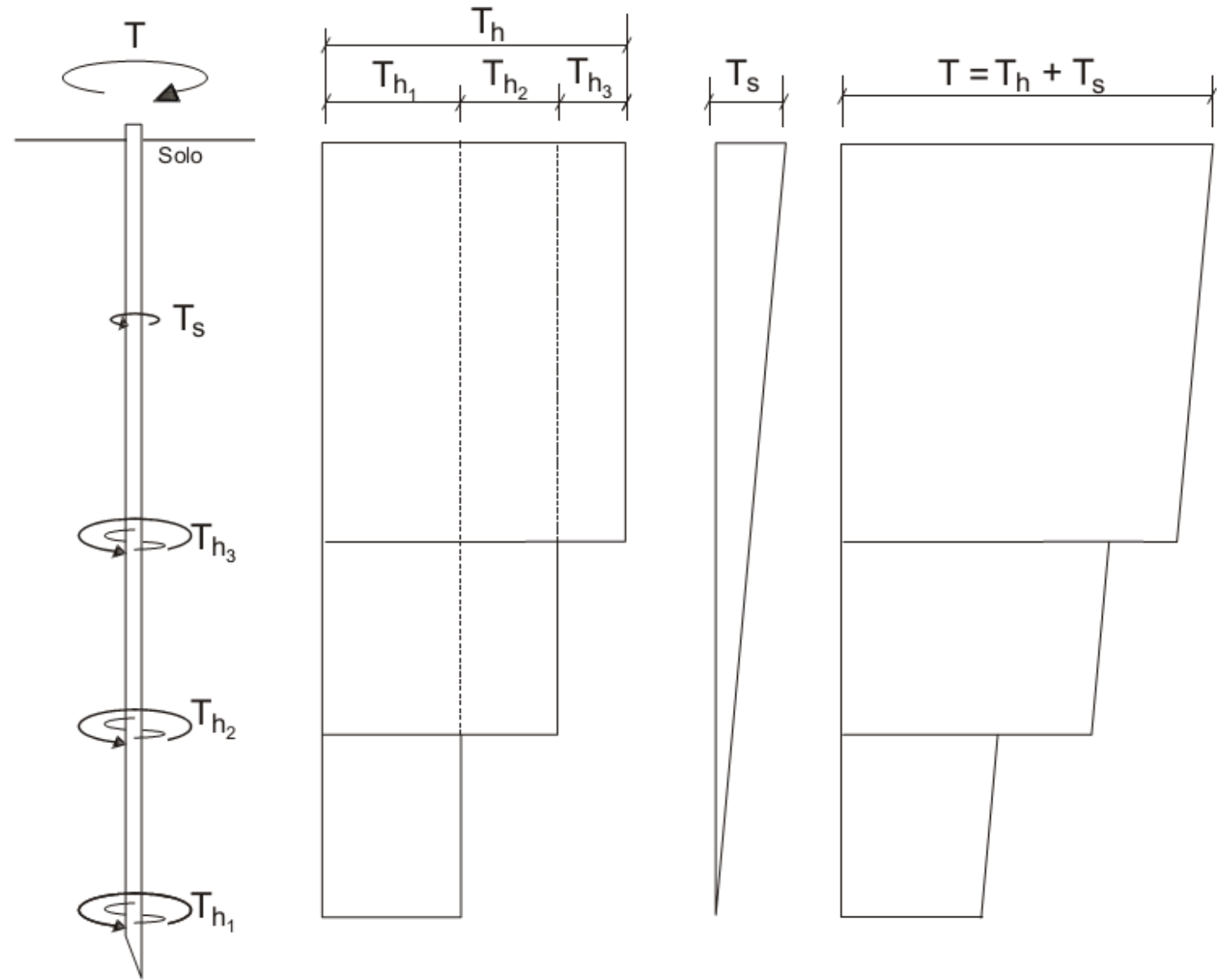

Figura 5.9: Parcelas de torque mobilizadas durante a instalação da estaca helicoidal (Tsuha e Aoki, 2010).

Adicionalmente a esta comparação, a Figura 5.10 mostra os valores das parcelas de torque relativos à instalação de cada hélice das estacas separadamente ao longo da profundidade. Estas parcelas foram obtidas pela diferença entre o torque de instalação de estacas com 2 hélices e com 1 hélice (mesmo diâmetro de hélice inferior) e da diferença entre o torque de instalação de estacas com 3 hélices e com 2 hélices (mesmo diâmetro das hélices inferiores).

No caso mostrado na Figura 5.10, a parcela relativa a primeira hélice (hélice do fundo) é apresentada juntamente com a parcela de torque mobilizada por atrito na haste (Ts da Figura 5.9). No entanto, como esta parcela Ts é referente ao atrito entre solo e haste durante a instalação da estaca após a passagem das hélices, ela é praticamente desprezível. Além disso, foi observada em todos os furos de instalação das estacas desta pesquisa uma região de aproximadamente 3 metros de profundidade onde não ocorre contato entre o solo e a haste (Figura 3.11). 

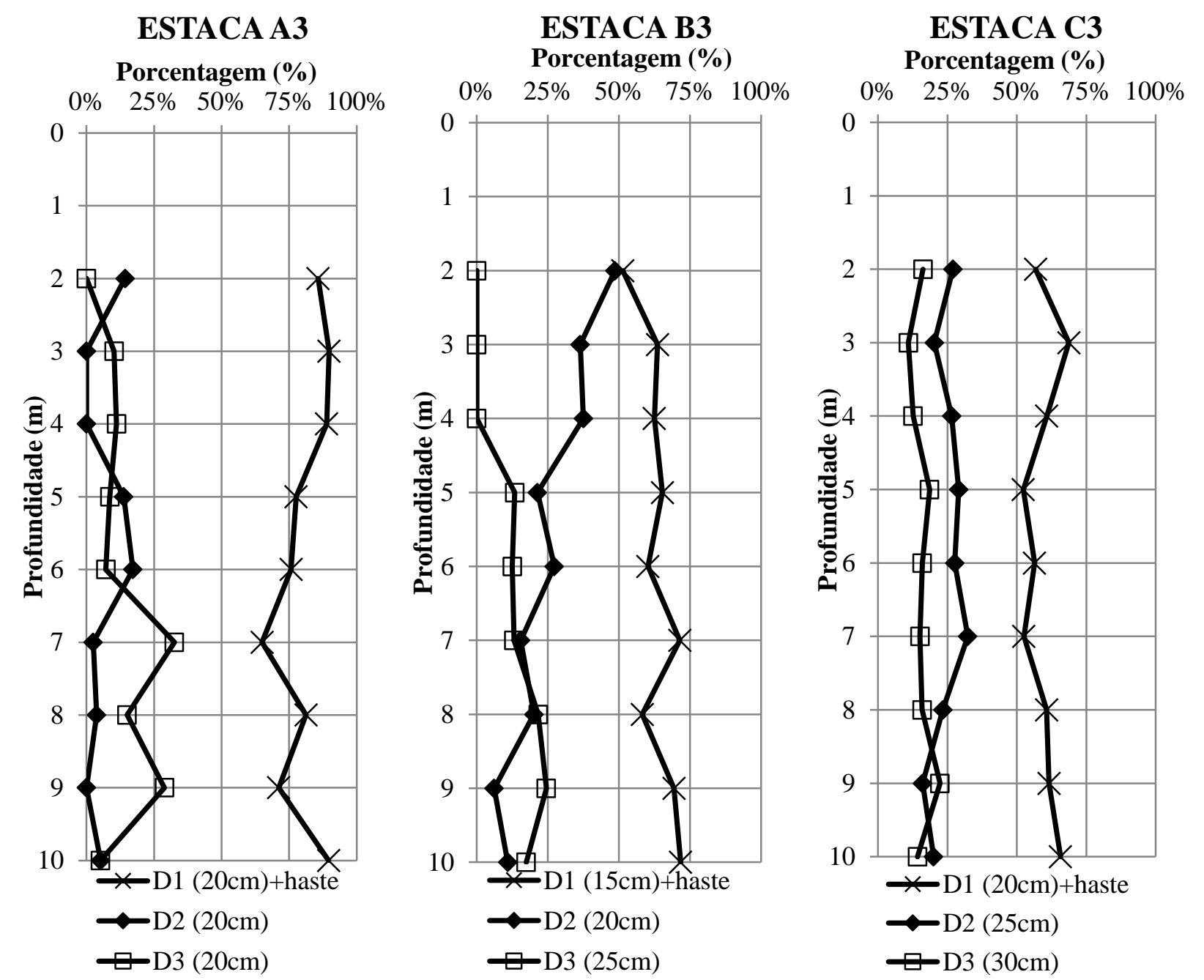

Figura 5.10: Gráficos com as parcelas de torque (em percentagem) resistida por cada hélice das estacas A3 (cilíndrica), B3 e C3 (cônicas) durante a instalação.

Nota-se pela Figura 5.10, que durante a instalação da estaca, as parcelas de torque resistido pelas hélices superiores são claramente menores, principalmente na configuração cilíndrica, no modelo de estaca A3. Nas estacas de modelo cônico, B3 e C3, as parcelas de torque resistido na primeira hélice também são maiores do que resistido pelas hélices superiores. No entanto, as parcelas de torque correspondentes às hélices superiores são em geral mais consideráveis para as estacas B3 e C3 do que no caso da A3, pelas primeiras possuírem diâmetros crescentes, e assim, durante a instalação atravessarem trechos intactos de solo, de modo a aumentar a contribuição das hélices superiores no valor de torque de instalação das estacas. 


\section{8}

No mais, observa-se pelas curvas da Figura 5.10 que os valores de torque resistidos pela primeira hélice (mais parcela da haste) das estacas são sempre maiores do que pelas outras hélices, independentemente da configuração das hélices. Observando-se a curva de instalação da estaca de configuração cilíndrica A3, confirma-se o efeito de instalação da primeira hélice na redução da resistência ao cisalhamento do solo de instalação da estaca a um valor quase “mínimo", tanto na camada de solo transportado (argiloso) quanto no solo residual abaixo (arenoso), ambos estruturados.

Portanto, efeito da configuração das hélices, considerando mesma profundidade, mesmo diâmetro médio e mesmo número de hélices, é de maiores torques para instalação de estacas cônicas do que cilíndricas, devido a soma dos torques exigidos na instalação das duas últimas hélices ser bem maior quando na geometria crescente do que com hélices de mesma geometria.

\subsubsection{EFEITO DA CONFIGURAÇÃO DAS HÉLICES NA CAPACIDADE DE CARGA À TRAÇÃO}

A capacidade da estaca helicoidal é composta por duas parcelas (independente dos métodos utilizados, expostos no item 2.2). A primeira parcela é devido a resistência ao cisalhamento dos cilindros de solo projetado acima das hélices (altura do cilindro mobilizado em torno de 2 a 3 diâmetros de hélice). A segunda parcela é resistência por atrito lateral ao longo da haste da estaca. Na maioria dos casos a parcela relativa ao atrito na haste é quase desprezível, exceto para os casos de estacas longas (onde terá grandes extensões de contato haste solo) ou com grande diâmetro de haste em relação ao diâmetro médio das hélices (onde a significativa área da haste eleva o atrito/aderência com o solo). Logo, a principal parcela de resistência é devido ao solo sobre as hélices.

O efeito de deslocamento do solo argiloso, durante o processo de instalação, nos primeiros metros da profundidade da estaca em torno da haste deixou um vazio, "gap" da Figura 3.11. Este fato induz à conclusão de que a parcela de resistência por atrito da haste seja pequena em relação as demais. Portanto, neste solo, a capacidade de carga à tração das estacas helicoidais é devido à resistência ao cisalhamento do solo acima das hélices, em sua maior parte. 
Para verificação do efeito da configuração das estacas helicoidais (cilíndrica ou cônica) na capacidade de carga, assim como realizado na análise do torque, as estacas comparadas devem possuir mesmo diâmetro médio e mesmo número de hélices para que a única variável seja a configuração das hélices. As únicas estacas ensaiadas com estas características são as estacas A3 e B3, as mesmas estacas das análises do torque de instalação na seção 5.5.1 anterior.

É notado na Figura 5.11 que as estacas com mesmo diâmetro médio e distintas configurações de hélices resultam em praticamente mesma capacidade de carga, embora os valores de torque necessários para instalá-las tenham sido diferentes.

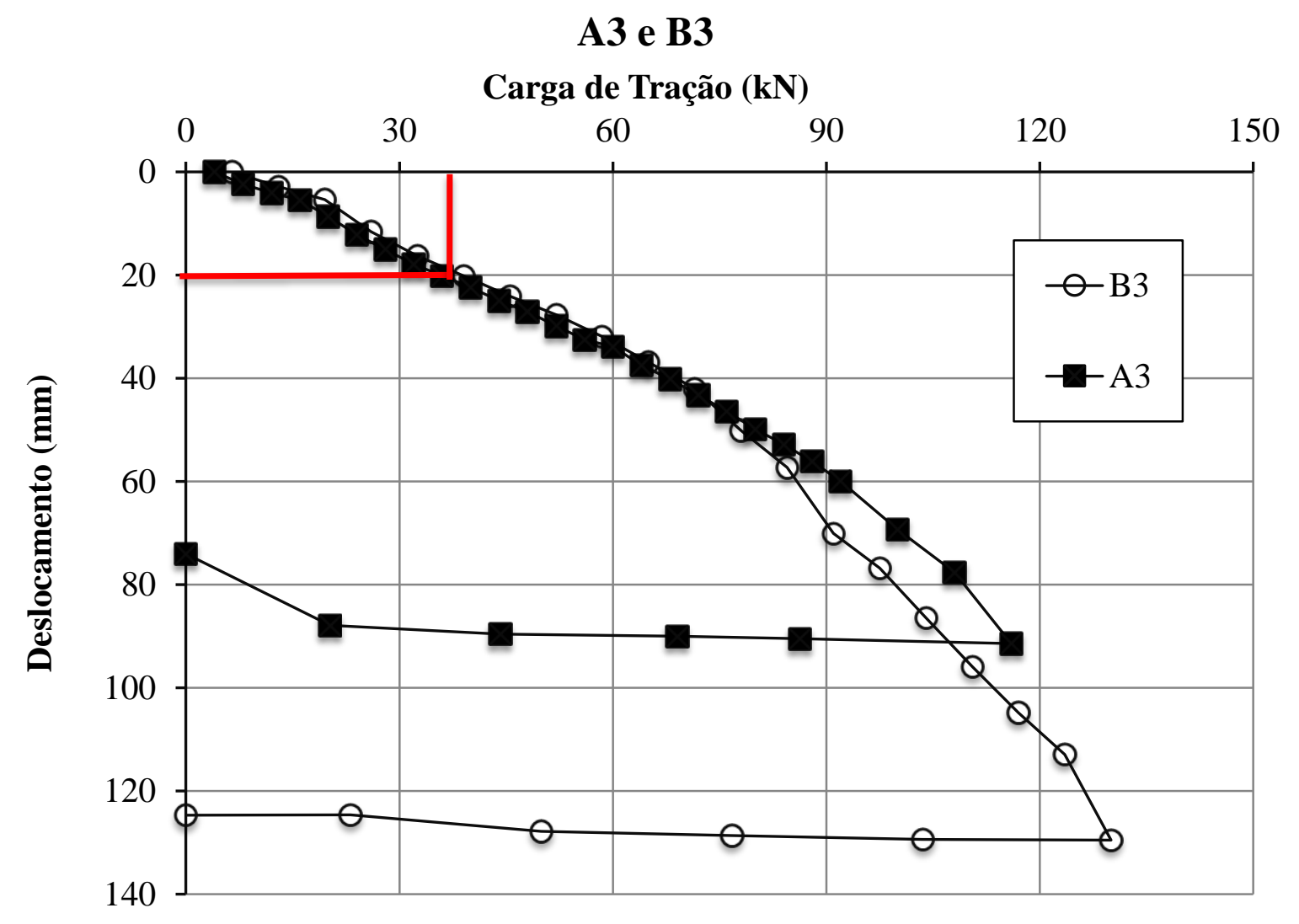

Figura 5.11: Comparação entre as curvas carga-deslocamento vertical das estacas A3 e B3.

Para melhor entendimento, a Figura 5.12 ilustra a situação de duas estacas helicoidais com o mesmo diâmetro médio e número de hélices, instaladas no perfil de solo tropical não saturado de baixa resistência. 


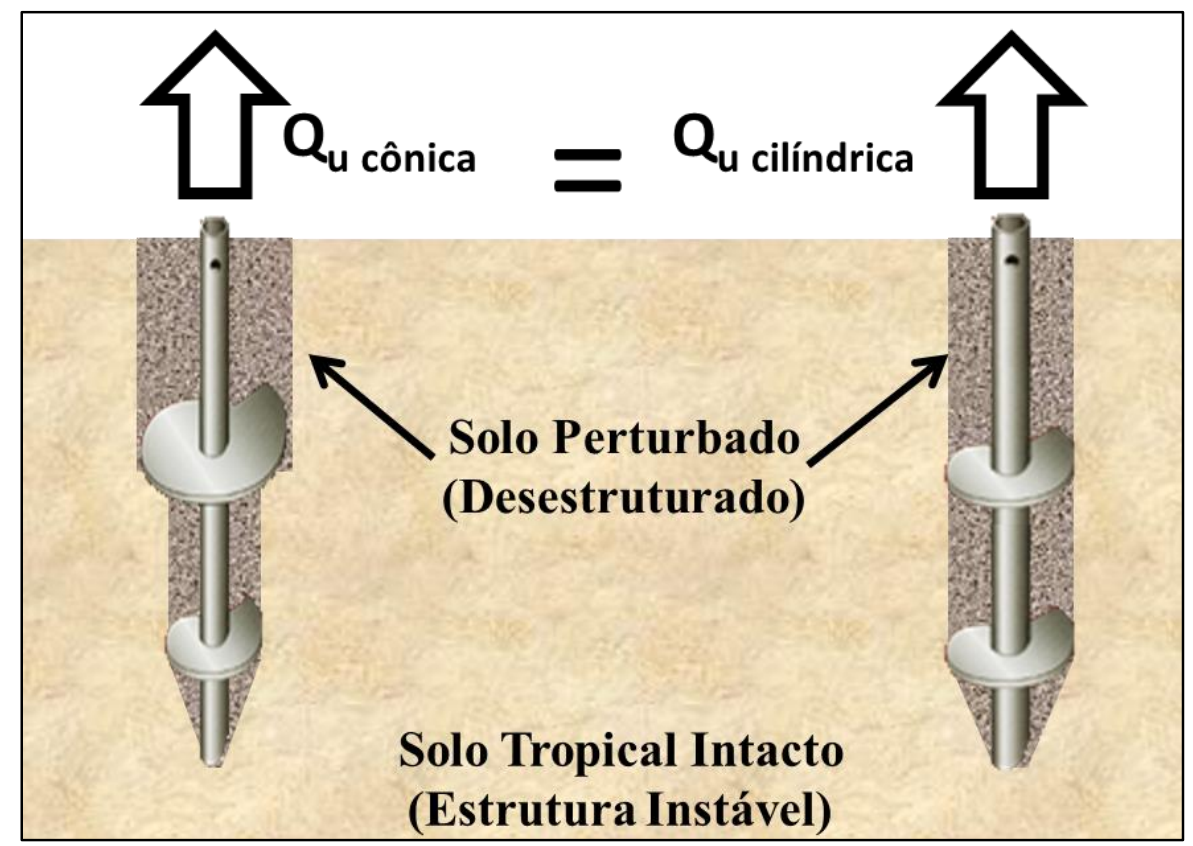

Figura 5.12: Perturbação do solo tropical com a instalação da estaca e seu efeito na capacidade de carga a tração da mesma.

A Figura 5.12 ilustra a hipótese de um fenômeno onde devido a capacidade de carga à tração de estacas helicoidais ser dependente da região perturbada e do estado final do solo após a instalação, ocorre o seguinte:

- Na situação intacta o solo mantém sua resistência adicional devido sua estrutura, sucção e cimentação.

- Na situação perturbada o solo se encontra apenas com uma resistência ao cisalhamento "residual", pois ao passar da primeira hélice o solo já perde sua resistência adicional e a passagem de novas hélices não pioram ou degradam mais o solo que está em sua condição de resistência mínima.

Segundo Almeida et al (2011) os solos lateríticos (tropicais) possuem estrutura porosa e instável devido às conexões entre partículas e a matriz gerada pela cimentação, dando à massa de solo uma resistência adicional em condições intactas (não perturbadas) e não saturadas. Em ambos os casos, após a passagem da primeira hélice a estrutura instável do solo tropical é alterada 
e atinge sua pior situação de resistência, onde mais passagens de hélice não pioram as propriedades do solo, ou seja, atinge um estado mínimo (residual) de resistência ao cisalhamento.

Portanto, após a instalação da estaca os cilindros de solo acima da primeira, da segunda ou terceira hélice possuem a mesma magnitude de resistência ao cisalhamento em ambas as estacas. Logo, tendo-se estacas de mesmo diâmetro médio, possuem então a mesma soma de área resistente (apesar de diferentes configurações das hélices), levando então a mesma capacidade de carga à tração. Pressupõe-se então que o motivo relevante da igualdade da capacidade de carga entre as estacas A3 e B3 seja relacionada ao efeito da instalação aliado ao tipo de solo, sua formação e consistência, ou seja, por ser solo tropical estruturado de baixa e média resistência $\left(\mathrm{N}_{\text {SPT }}\right.$ entre 6 e 7$)$.

Os resultados de Lutenegger (2011) também mostraram que a configuração das hélices não influência significativamente na capacidade de carga. Curiosamente seus resultados foram inversos aos esperados. Os resultados da Figura 5.8 mostram que as estacas cônicas geram maiores torques do que as cilíndricas, levando a crer que as cônicas obteriam maiores capacidades de carga devido ao fator torque $\left(\mathrm{K}_{\mathrm{T}}\right)$. Entretanto, os resultados da Tabela 2.4 de Lutenegger (2011) mostram que as estacas cilíndricas possuíram maior capacidade de carga, conclusão contrária ao esperado.

Isso leva a necessidade de maior reflexão sobre a correlação da capacidade de carga e torque com o efeito da instalação. Conclui-se também que a configuração das hélices da estaca helicoidal não influenciam na capacidade de carga a tração da mesma, ao passo que a configuração influência nos torques de instalação, onde as estacas cônicas exigem mais torque de instalação do que as estacas cilíndricas. 


\subsection{EFEITO DO NÚMERO DE HÉLICES NO TORQUE E NA CAPACIDADE DE CARGA À TRAÇÃO}

Neste item é apresentado discussões a respeito do efeito do número de hélices no torque e na capacidade de carga à tração das estacas metálicas helicoidais.

\subsubsection{EFEITO DAS HÉLICES NO TORQUE DE INSTALAÇÃO}

Observou-se pelos gráficos de instalação das estacas que os valores de torque resistidos primeira hélice são sempre maiores. Isso novamente confirma o efeito de instalação na degradação das propriedades do solo tropical, tanto no trecho argiloso laterítico quanto no trecho silte arenoso residual de alteração, ambos estruturados.

As parcelas restantes de torque resistidos pelas outras hélices são bem menores, principalmente na configuração cilíndrica, modelo A. Nas estacas de modelo cônico, B e C, as parcelas de torque também são maiores na primeira hélice, no entanto, a parcela correspondente as restantes das hélices são mais consideráveis, devido possuírem diâmetros maiores e assim na instalação cortam trechos intactos de solo, aumentando assim a contribuição de torque destas hélices.

Segue abaixo as tabelas com resumo dos resultados (Tabela 5.5 e Tabela 5.6), e os gráficos (Figura 5.13) em profundidade.

Tabela 5.5: Valores das parcelas de torque de instalação correspondentes a cada hélice para cada um dos modelos das estacas ensaiadas.

\begin{tabular}{|c|c|c|c|c|c|c|c|c|c|}
\hline \multirow{4}{*}{$\operatorname{Prof}(\mathbf{m})$} & \multicolumn{9}{|c|}{ Efeito das Hélices - Torque devido a cada hélice (kN.m) } \\
\hline & \multicolumn{3}{|c|}{ Hélices Iguais (A) } & \multicolumn{3}{|c|}{ Hélices Crescentes (B) } & \multicolumn{3}{|c|}{ Hélices Crescentes $(\mathbf{C})$} \\
\hline & D1 $(20 \mathrm{~cm})+\mathrm{Ts}$ & D2 (20cm) & D3 (20cm) & D1 (15cm)+Ts & D2 (20cm) & D3 (25cm) & D1 $(20 \mathrm{~cm})+\mathrm{Ts}$ & D2 (25cm) & D3 (30cm) \\
\hline & $\mathbf{A 1}$ & A2 - A1 & A3 - A2 & B1 & B2 - B1 & B3 - B2 & A1 & $\mathrm{C2}-\mathrm{A1}$ & $\mathrm{C3}-\mathrm{C2}$ \\
\hline 2,0 & 2,79 & 0,46 & 0,00 & 2,52 & 2,39 & 0,00 & 2,79 & 1,33 & 0,80 \\
\hline 3,0 & 2,92 & 0,00 & 0,33 & 2,79 & 1,59 & 0,00 & 2,92 & 0,86 & 0,46 \\
\hline 4,0 & 3,19 & 0,00 & 0,40 & 2,99 & 1,79 & 0,00 & 3,19 & 1,39 & 0,66 \\
\hline 5,0 & 2,99 & 0,53 & 0,33 & 3,25 & 1,06 & 0,66 & 2,99 & 1,66 & 1,06 \\
\hline 6,0 & 3,52 & 0,80 & 0,33 & 3,52 & 1,59 & 0,73 & 3,52 & 1,73 & 1,00 \\
\hline 7,0 & 3,45 & 0,13 & 1,73 & 3,98 & 0,86 & 0,73 & 3,45 & 2,12 & 1,00 \\
\hline 8,0 & 4,32 & 0,20 & 0,80 & 3,75 & 1,29 & 1,39 & 4,32 & 1,66 & 1,13 \\
\hline 9,0 & 4,58 & 0,00 & 1,86 & 4,52 & 0,40 & 1,59 & 4,58 & 1,20 & 1,66 \\
\hline 10,0 & 4,58 & 0,27 & 0,27 & 4,38 & 0,66 & 1,06 & 4,58 & 1,39 & 1,00 \\
\hline
\end{tabular}


A3

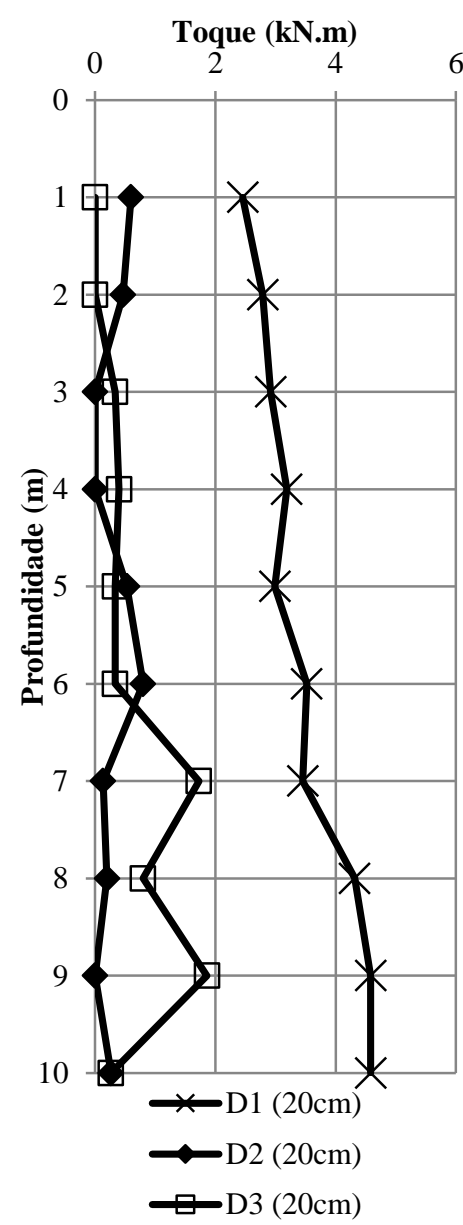

B3

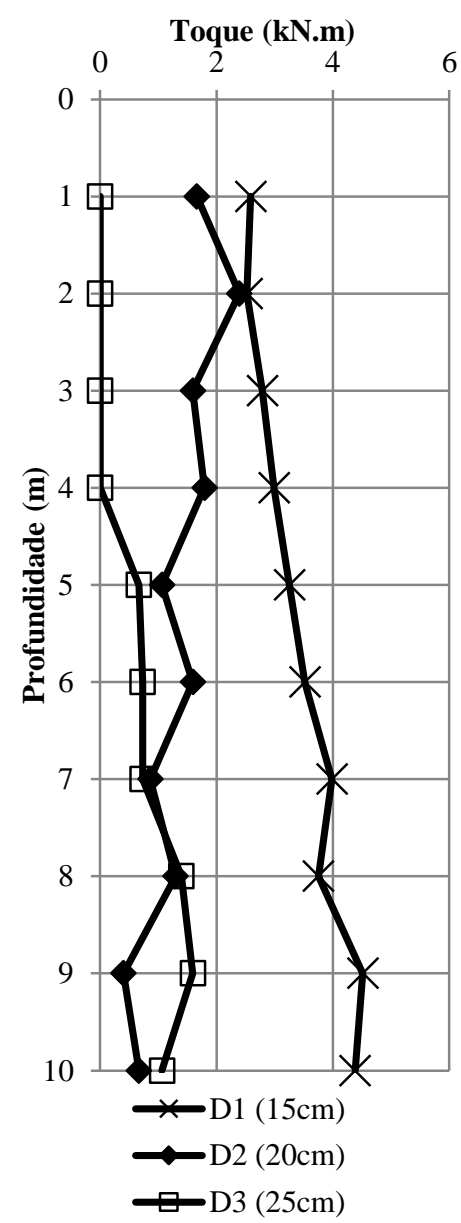

C3

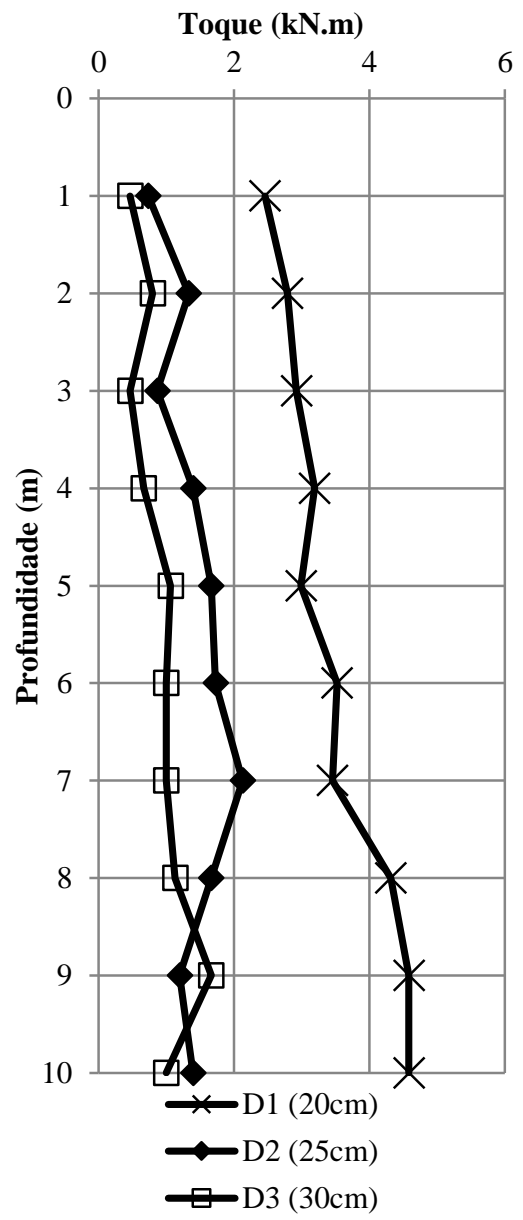

Figura 5.13: Parcelas de torque de instalação correspondentes a cada hélice das estacas A3, B3 e C3.

Tabela 5.6: Valores das porcentagens do torque de instalação correspondentes a cada hélice para cada um dos modelos das estacas ensaiadas

\begin{tabular}{|c|c|c|c|c|c|c|c|c|c|}
\hline \multirow{4}{*}{ Prof (m) } & \multicolumn{9}{|c|}{ Efeito das Hélices - Porcentagem de Torque de cada hélice / Total (\%) } \\
\hline & \multicolumn{3}{|c|}{ Hélices Iguais (A) } & \multicolumn{3}{|c|}{ Hélices Crescentes $(B)$} & \multicolumn{3}{|c|}{ Hélices Crescentes (C) } \\
\hline & D1 $(20 \mathrm{~cm})+1$ & D2 $(20 \mathrm{~cm})$ & D3 $(20 \mathrm{~cm})$ & D1 $(15 \mathrm{~cm})+\mathrm{T}$ & D2 (20cm) & D3 $(25 \mathrm{~cm})$ & D1 $(20 \mathrm{~cm})+\mathrm{T}$ & D2 $(25 \mathrm{~cm})$ & D3 $(30 \mathrm{~cm})$ \\
\hline & $1^{\circ}$ Hélice & $2^{\circ}$ Hélice & $3^{\circ}$ Hélice & $1^{\circ}$ Hélice & $2^{\circ}$ Hélice & $3^{\circ}$ Hélice & $1^{\circ}$ Hélice & $2^{\circ}$ Hélice & $3^{\circ}$ Hélice \\
\hline 2,0 & $86 \%$ & $14 \%$ & $0 \%$ & $51 \%$ & $49 \%$ & $0 \%$ & $57 \%$ & $27 \%$ & $16 \%$ \\
\hline 3,0 & $90 \%$ & $0 \%$ & $10 \%$ & $64 \%$ & $36 \%$ & $0 \%$ & $69 \%$ & $20 \%$ & $11 \%$ \\
\hline 4,0 & $89 \%$ & $0 \%$ & $11 \%$ & $63 \%$ & $38 \%$ & $0 \%$ & $61 \%$ & $27 \%$ & $13 \%$ \\
\hline 5,0 & $78 \%$ & $14 \%$ & $9 \%$ & $65 \%$ & $21 \%$ & $13 \%$ & $52 \%$ & $29 \%$ & $19 \%$ \\
\hline 6,0 & $76 \%$ & $17 \%$ & $7 \%$ & $60 \%$ & $27 \%$ & $13 \%$ & $56 \%$ & $28 \%$ & $16 \%$ \\
\hline 7,0 & $65 \%$ & $3 \%$ & $33 \%$ & $71 \%$ & $15 \%$ & $13 \%$ & $53 \%$ & $32 \%$ & $15 \%$ \\
\hline 8,0 & $81 \%$ & $4 \%$ & $15 \%$ & $58 \%$ & $20 \%$ & $22 \%$ & $61 \%$ & $23 \%$ & $16 \%$ \\
\hline 9,0 & $71 \%$ & $0 \%$ & $29 \%$ & $69 \%$ & $6 \%$ & $24 \%$ & $62 \%$ & $16 \%$ & $22 \%$ \\
\hline 10,0 & $90 \%$ & $5 \%$ & $5 \%$ & $72 \%$ & $11 \%$ & $17 \%$ & $66 \%$ & $20 \%$ & $14 \%$ \\
\hline
\end{tabular}




\subsubsection{EFEITO DO NÚMERO DE HÉLICES NA CAPACIDADE DE CARGA À TRAÇÃO}

A Tabela 5.7 apresenta uma síntese dos resultados de capacidade de carga das estacas ensaiadas, obtidas pelas curvas carga x deslocamento (Figura 4.15) e mostradas na Tabela 4.7.

Tabela 5.7: Resultados da capacidade de carga das estacas ensaiadas e as parcelas de contribuição de cada hélice.

\begin{tabular}{cccccccc}
\hline Estaca & $\begin{array}{c}\text { Configuração } \\
\text { Hélices }\end{array}$ & $\begin{array}{c}\mathbf{N}^{\mathbf{0}} \text { de } \\
\text { hélices }\end{array}$ & $\begin{array}{c}\text { Diâmetros } \\
\mathbf{( m m )}\end{array}$ & $\begin{array}{c}\text { Capacidade } \\
\text { de Carga, } \\
\text { Qu (kN) }\end{array}$ & $\begin{array}{c}\text { Contribuição } \\
\mathbf{1}^{\mathbf{a}} \text { hélice Qh1 } \\
\text { (inferior) }+ \\
\text { Qs (atrito na } \\
\text { haste, (\%) }\end{array}$ & $\begin{array}{c}\text { Contribuição } \\
\mathbf{2}^{\mathbf{a}} \text { hélice } \\
\text { (meio) } \\
\text { Qh2 (\%) }\end{array}$ & $\begin{array}{c}\text { Contribuição } \\
\mathbf{3}^{\mathbf{a}} \text { hélice } \\
\text { (superior) } \\
\text { Qh3 (\%) }\end{array}$ \\
\hline A1 & Cilíndrica & 1 & 200 & 14,5 & 100.0 & - & - \\
A2 & Cilíndrica & 2 & $200 / 200$ & 25 & 58.0 & 42.0 & - \\
A3 & Cilíndrica & 3 & $200 / 200 / 200$ & 36 & 40.3 & 29.2 & 30.6 \\
\hline B1 & Cônica & 1 & 150 & 13,5 & 100.0 & - & - \\
B2 & Cônica & 2 & $150 / 200$ & 31 & 43.5 & 56.5 & - \\
B3 & Cônica & 3 & $150 / 200 / 250$ & 39 & 34.6 & 44.9 & 20.5 \\
\hline C2 & Cônica & 2 & $200 / 250$ & 48 & 30.2 & 69.8 & - \\
C3 & Cônica & 3 & $200 / 250 / 300$ & 57 & 25.4 & 58.8 & 15.8 \\
\hline
\end{tabular}

Nesta tabela são apresentadas as frações relativas à contribuição das segundas e das terceiras hélices na capacidade de carga das estacas com duas e com três hélices $(\mathrm{Qu}=\mathrm{Qh}+\mathrm{Qs}$, onde Qh é a parcela de capacidade de carga devido às hélices, e Qs é a parcela devido à resistência por atrito lateral na haste). Estas frações foram obtidas pela diferença entre a capacidade de carga de estacas com 2 hélices e com 1 hélice (mesmo diâmetro de hélice inferior) e da diferença entre a capacidade de carga de estacas com 3 hélices e com 2 hélices (mesmo diâmetro das hélices inferiores). Pela Tabela 5.7 nota-se:

\section{a) Para estacas com duas hélices (A2, B2 e C2)}

Para a estaca helicoidal cilíndrica a segunda hélice contribuiu com $42 \%$ da capacidade de carga total da estaca A2. Já nas estacas cônicas esta contribuição da segunda hélice foi de 57 e $70 \%$ aproximadamente, para a B2 e C2 respectivamente. Este fato mostra que a contribuição da segunda hélice de uma estaca helicoidal de duas hélices é maior quando a estaca é cônica. Este fato é explicado porque nestes casos a segunda hélice além de ter maior área projetada do que a primeira está em solo menos perturbado (conforme ilustração da Figura 5.7). 
Comparando-se as estacas A2 e B2, o resultado da capacidade de carga da estaca B2 é maior do que da A2, mesmo a B2 tendo o diâmetro médio inferior (175mm). Explica-se este fato pelo importante ganho da segunda hélice por estar em solo menos perturbado no caso do B2 comparado ao caso da A2, além da diferença entre diâmetros (configuração cônica) ter permitido que as duas hélices (de 150mm e 200mm) pudessem ser carregadas ao máximo, diferente da segunda hélice de A2 que ficou inteiramente em solo perturbado pela primeira hélice.

\section{b) Para estacas com três hélices (A3, B3 e C3)}

Neste caso ocorreu o contrário. Para o caso do acréscimo de uma terceira hélice a contribuição da terceira hélice da estaca A3 (cilíndrica) foi maior do que das estacas B3 e C3 (configuração cônica). No entanto, neste caso a terceira hélice de menor diâmetro (200 mm) contribuiu mais proporcionalmente para a capacidade de carga do que as de maior diâmetro (250 e $300 \mathrm{~mm}$, da B3 e A3 respectivamente).

Este comportamento é similar ao encontrado em Tsuha et al. (2012) em areia compacta. Quanto maior o diâmetro da terceira hélice, menor a fração de contribuição para a capacidade de carga total. Estes autores têm como hipótese que este fato está ligado ao efeito da instalação no solo, e pode ser entendida através da Figura 5.14.

A região afetada pela instalação da estaca ao redor das hélices pode ser ilustrada através de um cilindro de solo perturbado. O diâmetro deste cilindro de solo perturbado ao redor das hélices possui certa proporcionalidade com o diâmetro das hélices, ou seja, quanto maior o diâmetro das hélices da estaca maiores serão os cilindros de solo perturbado ao redor da mesma. Por consequência, a superfície cilíndrica projetada da hélice (pontilhado em preto da Figura 5.14) que é mobilizada durante o carregamento da estaca fica mais distante do solo intacto quando o diâmetro da hélice é maior, e por consequência a tensão normal à superfície cilíndrica solicitada é inferior para hélices maiores. 


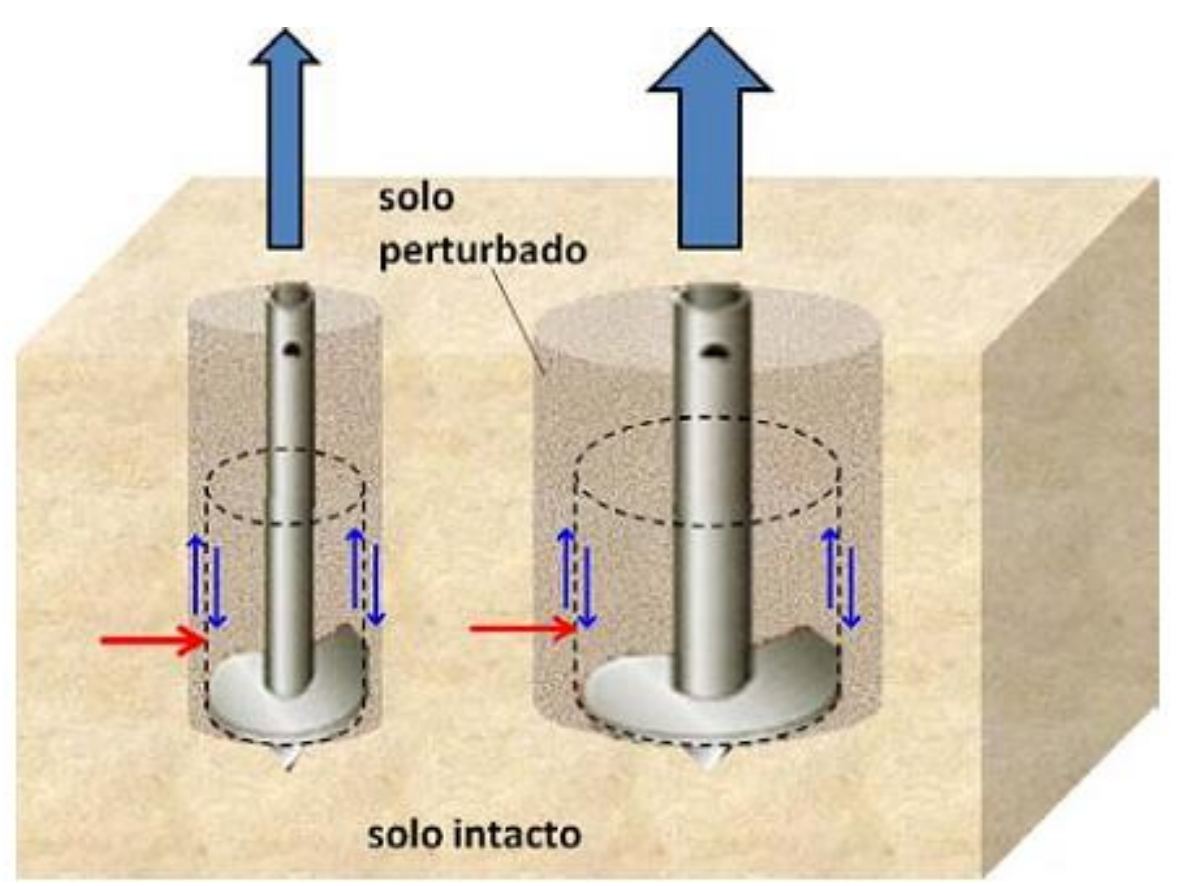

Figura 5.14: Ilustração do solo perturbado durante a instalação das hélices, e do cilindro de solo solicitado durante o carregamento à tração das estacas.

Ao mesmo tempo, diâmetros maiores de hélice, possuem maiores perímetros e, por conseguinte, maiores áreas de superfície cilíndricas que mobilizam resistência, logo, maiores diâmetros também geram maiores áreas resistentes e tendem a contribuir mais com a capacidade de carga.

Portanto, para o acréscimo de números de hélices na estaca helicoidal em solo tropical de baixa resistência, gerar acréscimo significativo na capacidade de carga à tração da estaca vai depender desta relação entre o ganho com o acréscimo de superfície resistente da hélice com a perda de resistência do solo devido ao maior cilindro de solo perturbado.

Tsuha et al (2012) também observa que em solos de baixas resistências, os efeitos de perda de resistências são menores, e por sua vez, solos mais resistentes perdem mais capacidade de carga com a instalação $\mathrm{O}$ efeito de instalação aqui arguido, e em coerência com os resultados de Tsuha et al (2012), possivelmente é o efeito que Lutenegger (2011) cita em suas conclusões.

Por meio de modelagem física em centrífuga de estacas helicoidais em areia Tsuha et al (2012) observaram fenômeno semelhante, em que para areia de baixa compacidade, o número de 
vezes em que ela for cortada pelas hélices não afeta a sua capacidade de carga. Diferentemente, em areia compacta, observou-se que quanto mais vezes a camada for cortada, menos resistente ela se torna. Nos ensaios deste trabalho, os resultados se assemelham ao caso de areia de baixa compacidade de Tsuha et al (2012).

\subsubsection{NFLUÊNCIA DO NÚMERO DE HÉLICES NA CURVA CARGA $\quad X$ DESLOCAMENTO VERTICAL EM CARREGAMENTOS DE TRAÇÃO}

Nesta seção é analisado o efeito da adição de novas hélices (de igual diâmetro) nas curvas "carga de tração x deslocamento vertical", usando-se os dados dos ensaios nas estacas A1, A2 e A3 (hélices de $20 \mathrm{~cm}$ ). Estes resultados são comparados na Figura $5.15 \mathrm{com}$ este efeito verificado nos ensaios de Clemence et al. (1994) apresentado no item 2.3.

Em ambas as figuras estão indicados em linha pontilhada os valores de deslocamentos correspondentes à carga de ruptura (10\% do diâmetro médio das hélices). Apesar da diferença do solo de instalação das estacas, e do diâmetro médio das hélices, a proporção de aumento na carga de tração devida à inclusão de uma nova hélice, para um mesmo deslocamento, é similar.

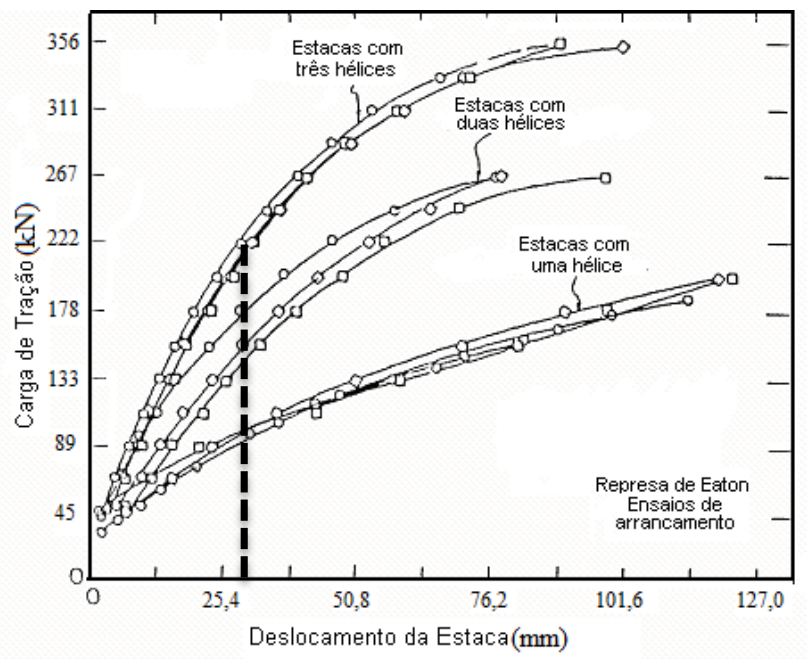

(a)

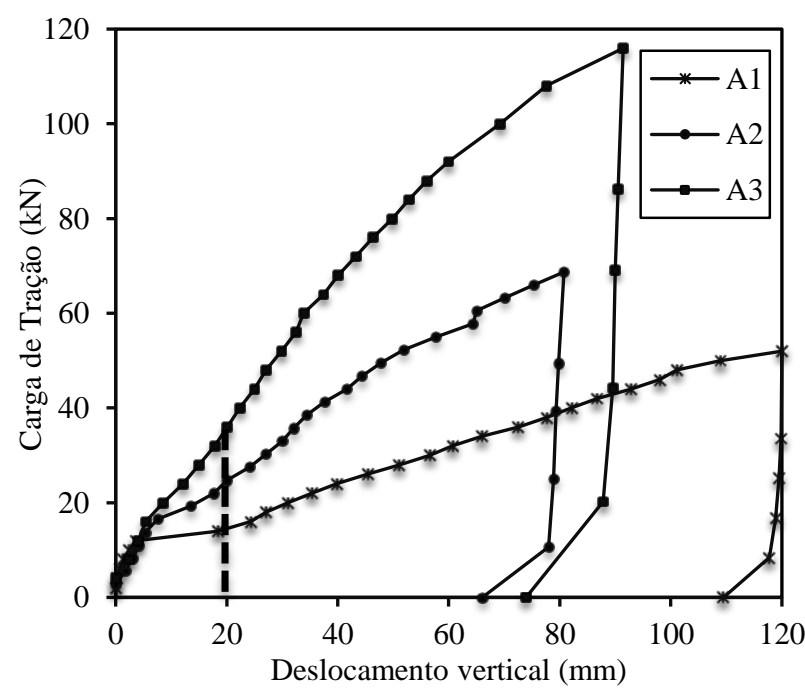

(b)

Figura 5.15: (a) Modificado de Ensaios de Clemence et al. (1994) e (b) Ensaios nas Estacas A1, A2 e A3.

Para o caso das estacas de Clemence et al. (1994), diferentemente do caso deste projeto, as curvas carga-deslocamento das estacas com maior número de hélices apresentam ruptura mais definida quando comparada à estacas com uma hélice. Nos resultados aqui encontrados conforme 
o aumento da carga de tração, o solo poroso acima das hélices torna-se mais compacto, e o início da ruptura não é claro como para as estacas de duas e três hélices da Figura 5.15(a).

\subsection{VERIFICAÇÃO DA INFLUÊNCIA DO DIÂMETRO MÉDIO NO TORQUE E CAPACIDADE DE CARGA}

Nesta análise do efeito do diâmetro das hélices, verificam-se como alterações no diâmetro médio das estacas resultam em variações de capacidade de carga. Pode ser constatado na Tabela 4.7 que o aumento da capacidade de carga está relacionado ao acréscimo do diâmetro médio. Neste caso têm que se manter a profundidade e número de hélices, aumentando-se apenas diâmetro médio das hélices. Sendo assim, compara-se a estaca A2 e B2, B2 e C2 e B3 e C3.

\section{a) Estaca com duas hélices (A2 e B2)}

Primeiramente são comparadas na Figura 5.16 o desempenho das estacas de duas hélices, A2 e B2, que não apresentam o mesmo diâmetro médio, no entanto, estes são bem próximos entre si (200 mm e $175 \mathrm{~mm}$, respectivamente).

A Figura 5.16 mostra que até o deslocamento vertical da haste no topo da estaca em cerca de $55 \mathrm{~mm}$, o desempenho da estaca B2 (menor diâmetro médio) de configuração cônica foi melhor (razão já explicada no texto no item 5.6.2). No entanto, como a área total projetada das hélices (proporcional a Dmédio) da estaca B2 é menor do que da A2, numa fase de grandes deslocamentos, após a ruptura, a estaca A2 suporta um nível de carga ligeiramente maior (a curva de A2 supera a de B2 a partir de $65 \mathrm{~mm}$ de deslocamento vertical).

Portanto, apesar da estaca B2 obter ligeiro melhor desempenho em níveis de ruptura convencionais de deslocamento, em altos níveis de deslocamento a estaca A2, com maior diâmetro médio, possui melhor desempenho mecânico. No entanto, a configuração das estacas influenciou no resultado do efeito do acréscimo de diâmetro médio das estacas. 


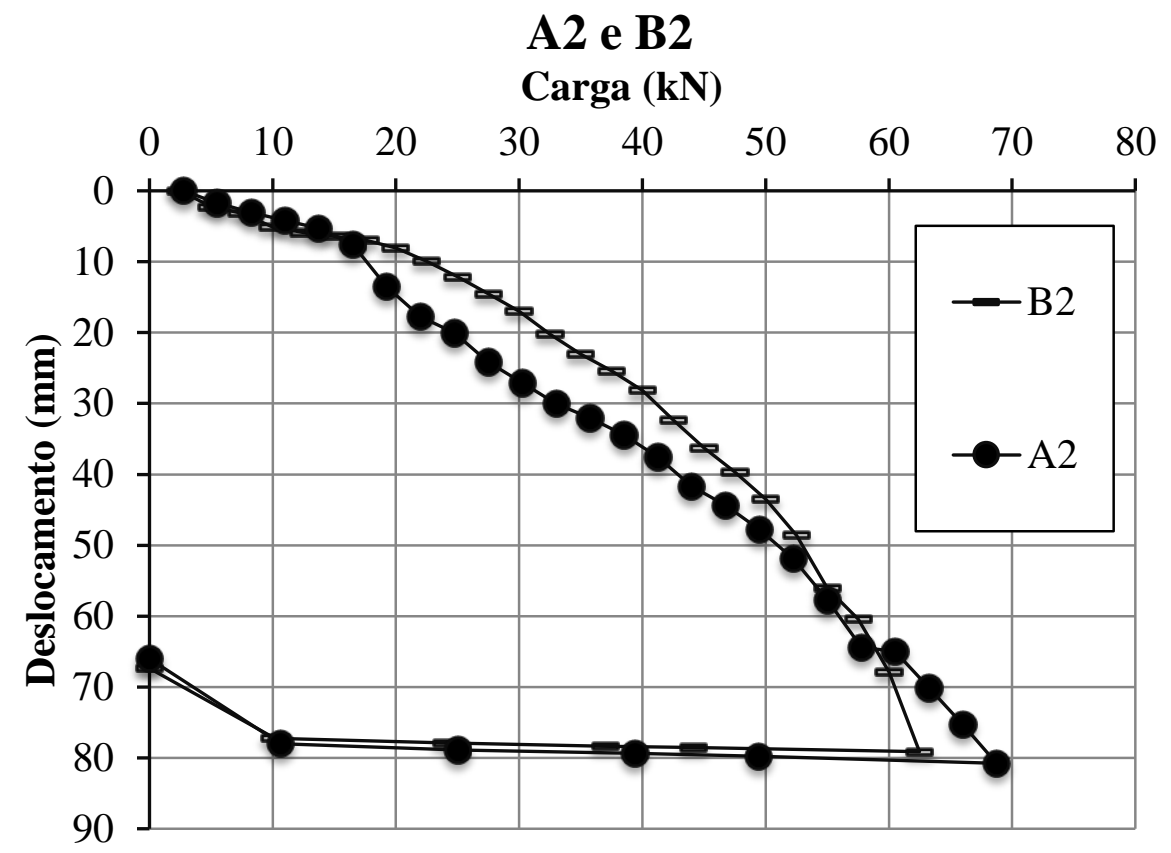

Figura 5.16: Gráfico de comparação das curvas Carga vs Deslocamento vertical das estacas A2 e B2 (B2 com $175 \mathrm{~mm}$, A2 com 200mm).

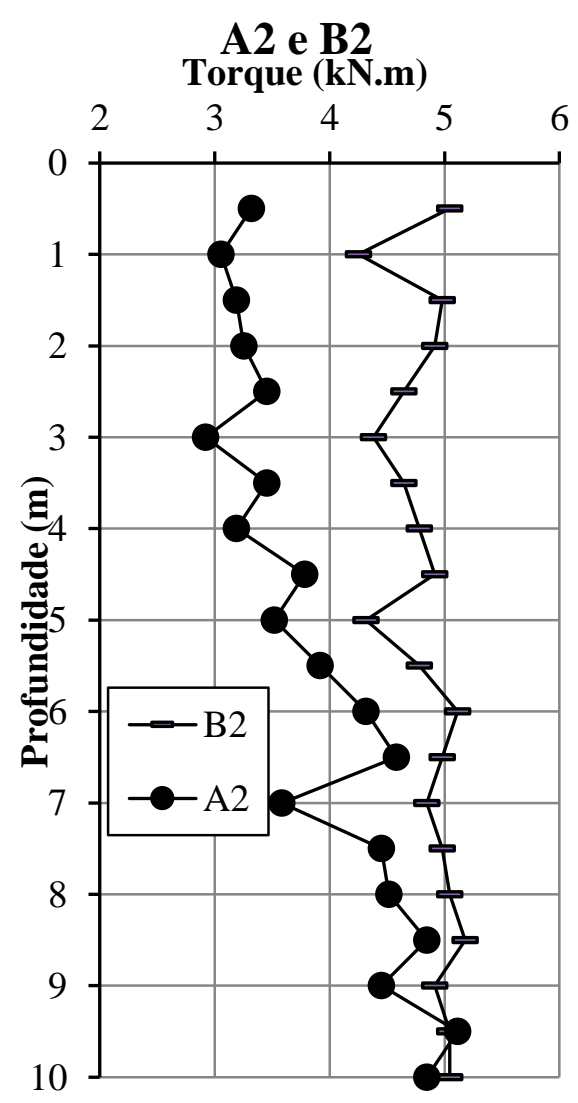

Figura 5.17: Toques de instalação em profundidade das estacas A2 e B2 
Para excluir o efeito da configuração das hélices são comparadas apenas as estacas de configuração cônica (B2 com C2 e B3 com C3). Assim, segue o quadro resumo (Tabela 5.8) da influência dos acréscimos de diâmetro médio na capacidade de carga à tração da estaca helicoidal, considerando as cargas últimas medidas $(\mathrm{Qu})$ e as estimadas pelos métodos de capacidades de carga individuais (Qu cap) e ruptura cilíndrica (Qu cil).

Tabela 5.8: Quadro resumo da influência do acréscimo do diâmetro médio das hélices da estaca $\Delta$ Dmed no acréscimo de capacidade de carga à tração $\Delta \mathrm{Qu}$

\begin{tabular}{ccccc}
\hline $\begin{array}{c}\text { Estacas } \\
\text { Comparadas }\end{array}$ & $\Delta$ Dmed & $\Delta \mathbf{Q u}$ & $\Delta \mathbf{Q u}$ cap & $\Delta \mathbf{Q u}$ cil \\
\hline B3 e C3 & $25 \%$ & $46 \%$ & $52 \%$ & $25 \%$ \\
B2 e C2 & $29 \%$ & $55 \%$ & $65 \%$ & $25 \%$ \\
\hline
\end{tabular}

Como esperado, e também de acordo com os métodos de previsão de capacidade de carga à tração das estacas helicoidais (ambos os métodos), a capacidade de carga à tração aumenta com o aumento do diâmetro médio das hélices da estaca helicoidal. Observa-se em mais detalhes abaixo.

\section{b) Estaca com duas hélices (B2 e C2)}

Comparando-se as estacas com duas hélices de configuração cônica B2 (diâmetro médio das hélices igual a 175mm) e C2 (diâmetro médio das hélices igual a 225mm), tem-se um aumento de $29 \%$ no diâmetro médio de B2 para C2 e nota-se um aumento médio em torno de $55 \%$ (Tabela 5.8) na capacidade de carga da estaca.

Pelo método das capacidades individuais (HOYT e CLEMENCE, 1989), o valor previsto para o aumento da capacidade de carga estaca C2 em relação à B2 seria de 65\%. No entanto, pelo método da ruptura cilíndrica (MITSCH e CLEMENCE, 1985) este aumento seria de apenas 25\%. (Tabela 5.8)

O valor medido de $55 \%$ é mais aproximado ao valor previsto pelo método das capacidades individuais do que o método de ruptura cilíndrica, nesta estaca cônica de duas hélices. 


\section{c) Estaca com três hélices (B3 e C3)}

Comparando-se os valores de capacidade de carga das estacas de configuração cônica com três hélices B3 (diâmetro médio das hélices igual a 20cm) com a estaca C3 (diâmetro médio das hélices igual a 22,5 cm), nota-se um aumento médio em torno de 46\% (Tabela 5.8) na capacidade de carga da estaca de maior diâmetro de hélices (C3).

Pelo método das capacidades individuais (HOYT e CLEMENCE, 1989), o valor previsto para o aumento da capacidade de carga estaca C3 em relação à B3 seria de 51\%. No entanto pelo método da ruptura cilíndrica (MITSCH e CLEMENCE, 1985) este aumento seria de 25\%. Do mesmo modo que para a estaca de duas hélices, o aumento de capacidade de carga com o aumento do diâmetro médio está mais próximo do valor previsto pelo método das capacidades individuais. (Tabela 5.8)

Observa-se então para ambas as estacas de configuração cônica, com duas ou três, que o modo de ruptura por capacidades de cargas individuais estimou melhor o efeito do acréscimo de diâmetro na capacidade de carga.

Na Figura 5.18 vê-se a relação entre a variação percentual do diâmetro médio e o correspondente acréscimo da capacidade de carga à tração, tanto o acréscimo real, Qu, via dados da prova de carga quanto acréscimo estimados pelos métodos capacidade de cargas individuais (Qu cap) e ruptura cilíndrica (Qu cil).

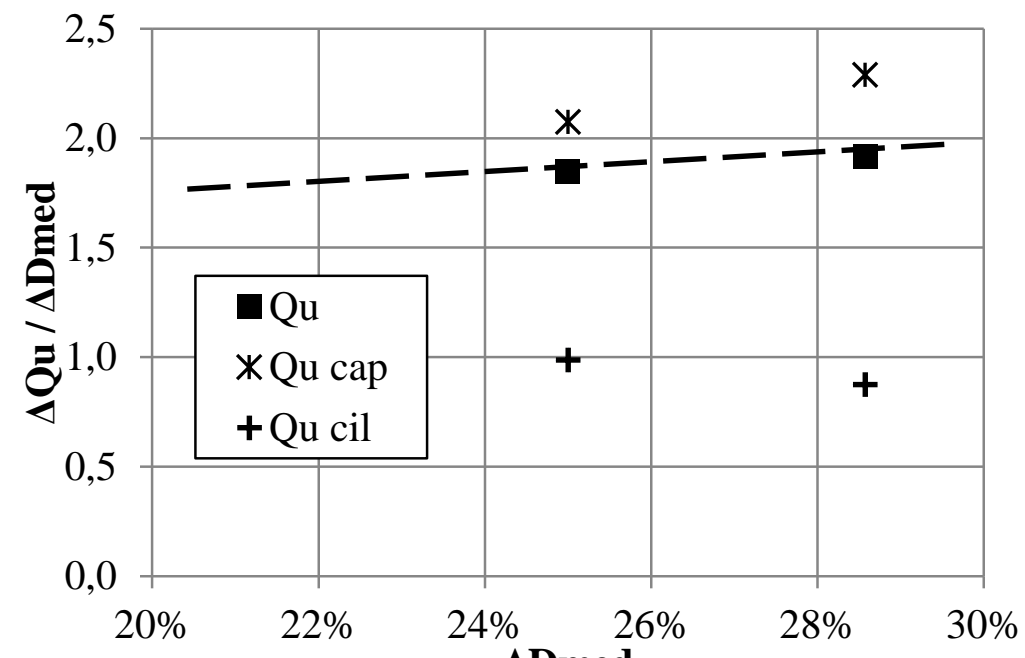

$\Delta$ Dmed

Figura 5.18: Gráfico do efeito do diâmetro médio na capacidade de carga das estacas. 
Na Figura 5.18 confirma-se a conclusão do método de capacidades individuais ser o mais adequado para estimar o efeito do acréscimo de diâmetro médio das hélices. Observa-se também que acréscimos por volta de 25 a $30 \%$ do diâmetro médio da estaca geram de 45 a $55 \%$ de acréscimo na capacidade de carga à tração, ou seja, o acréscimo da capacidade de carga é quase o dobro do acréscimo do diâmetro médio das hélices da estaca.

Portanto, o efeito do acréscimo do diâmetro médio de uma estaca helicoidal de configuração cônica é vantajoso quando na questão de capacidade de carga.

\subsection{AVALIAÇÃO DO FATOR DE TORQUE KT EM SOLOS TROPICAIS}

Este procedimento de controle da capacidade de carga de estacas helicoidais usado na prática é baseado em regras empíricas, que relaciona torque final de instalação e capacidade de carga das estacas, e foram estabelecidas pela experiência de empresas executoras deste tipo de fundação. (Ver melhor no item 2.2.3)

A relação entre torque final de instalação e capacidade de carga de estacas helicoidais, como citado em Hoyt e Clemence (1989) é dada pela equação apresentada no item 2.2.3, e através da seguinte equação:

$$
K_{t}=\frac{Q_{u}}{T}
$$

Como ilustra a Tabela 5.9 os valores recomendados na literatura são significantemente superiores aos medidos nos ensaios desta pesquisa. Estes valores foram calibrados utilizando-se ensaios realizados em países de clima temperado, ou seja, em solos com características distintas do solo tropical poroso e estruturado desta pesquisa. Para as estacas ensaiadas neste projeto, os valores de $\mathrm{K}_{\mathrm{T}}$ encontrados são bem inferiores aos recomendados na literatura. 
Tabela 5.9: Quadro comparativo entre os resultados de $\mathrm{K}_{\mathrm{T}}$ medidos e os sugeridos pela literatura.

\begin{tabular}{ccccccc}
\hline Estaca & $\begin{array}{c}\text { Configuração } \\
\text { Hélices }\end{array}$ & $\begin{array}{c}\text { D médio } \\
(\mathbf{m m})\end{array}$ & $\begin{array}{c}\text { Qu } \\
(\mathbf{k N})\end{array}$ & $\begin{array}{c}\text { Torque } \\
(\mathbf{k N . m})\end{array}$ & $\begin{array}{c}\mathbf{K}_{\mathbf{T}}\left(\mathbf{m}^{-1}\right) \\
\text { Medidos }\end{array}$ & $\begin{array}{c}\mathbf{K}_{\mathbf{T}}\left(\mathbf{m}^{-\mathbf{1}}\right) \\
\text { Literatura }\end{array}$ \\
\hline A1 & Cilíndrica & 200 & 14,5 & 4,6 & 3,2 & 14 a 42 \\
\hline A2 & Cilíndrica & 200 & 25 & 4,9 & 5,1 & 22 a 33 \\
\hline A3 & Cilíndrica & 200 & 36 & 5,1 & 7,1 & 22 a 33 \\
\hline B1 & Cônica & 150 & 13,5 & 4,4 & 3,1 & 22 a 33 \\
\hline B2 & Cônica & 175 & 31 & 5,1 & 6,1 & 22 a 33 \\
\hline B3 & Cônica & 200 & 39 & 6,1 & 6,4 & 22 a 33 \\
\hline C2 & Cônica & 225 & 48 & 6,0 & 8,0 & 22 a 33 \\
\hline C3 & Cônica & 250 & 57 & 7,0 & 8,1 & 22 a 33 \\
\hline
\end{tabular}

Obs: Literatura corresponde a Perko (2009), Tsuha et al (2009) e Hoyt e Clemence (1989).

Para este solo a parcela de resistência quando intacto, devido às suas características peculiares, é reduzida em grande parte após a instalação das hélices. Deste modo, as estacas helicoidais nesses solos apresentam um comportamento particular. Como o valor de $\mathrm{K}_{\mathrm{T}}$ representa a relação entre a resistência do solo acima das hélices após a instalação $(\mathrm{Qu})$ e a resistência ao cisalhamento do solo durante a instalação $(\mathrm{T})$ e a primeira é correspondente a um solo de baixa resistência em relação à segunda, os valores encontrados de $\mathrm{K}_{\mathrm{T}}$ são significantemente inferiores ao encontrado na literatura, o que corresponde a experiência deste tipo de estaca instaladas em solos distintos dos solos tropicais da presente pesquisa.

Esta tendência de valores de $\mathrm{K}_{\mathrm{T}}$ abaixo dos valores recomendados na literatura foi observada em estacas helicoidais utilizadas para fundações de torres de linhas de transmissão de energia. Em uma obra específica foram executadas estacas helicoidais em terreno similar a região do presente projeto. Algumas estacas helicoidais desta obra observada, que ficaram longas (mais do que 20 metros), no entanto, com as hélices instaladas em solo residual arenoso com baixo valor de $\mathrm{N}_{\mathrm{SPT}}\left(\mathrm{em}\right.$ torno de 10 a 15 golpes $/ 30 \mathrm{~cm}$ ), apresentaram valores de $\mathrm{K}_{\mathrm{T}}$ entre 8 e $10 \mathrm{~m}^{-1}$.

Portanto, para estacas neste tipo de solo de $\mathrm{N}_{\mathrm{SPT}}$ em torno de 10 golpes/30cm não é recomendada a utilização dos valores de $\mathrm{K}_{\mathrm{T}}$ encontrados na literatura para a previsão da capacidade de carga com base no valor de torque de instalação. 


\section{4}

Além disso, os valores de $\mathrm{K}_{\mathrm{T}}$ recomendados na literatura não variam com o número de hélices, e pela Tabela 5.9 nota-se que esta razão aumenta com o número de hélices, devido ao fato da parcela de torque resistida pelas hélices superiores ser correspondente à resistência ao cisalhamento do solo perturbado, e o valor do torque final de instalação não aumenta com a adição de mais hélices na mesma proporção em que é aumentada a capacidade de carga da estaca à tração.

No entanto, observou-se nesta mesma obra citada, que as estacas que ficaram com hélices instaladas em camada de solo com $\mathrm{N}_{\mathrm{SPT}}$ em média superior a 25 golpes $/ 30 \mathrm{~cm}$, apresentaram por meio de provas de carga, valores de $\mathrm{K}_{\mathrm{T}}$ em torno de $30 \mathrm{~m}^{-1}$, que está dentro do intervalo recomendado na literatura.

Deste modo, considerando-se o fato de que os valores de capacidade de carga das estacas ensaiadas nesta pesquisa foram baixos, e também por meio das informações obtidas da prática de estacas helicoidais instaladas em solos residuais da região, conclui-se que as hélices das estacas não devem ser ancoradas neste tipo solo tropical, estruturado e poroso, com valores de inferiores a 10 golpes $/ 30 \mathrm{~cm}$.

Portanto, os valores de $\mathrm{K}_{\mathrm{T}}$ recomendados pela literatura não são aplicáveis aos solos tropicais de baixa resistência similares ao desta pesquisa, pois os resultados para este são inferiores aos da literatura. E para as estacas apresentarem um bom desempenho devem ser instaladas em solo residual que apresente valores de $\mathrm{N}_{\text {SPT }}$ mais elevados (solo com maior resistência penetração). 


\subsection{VERIFICAÇÕES DO NÚMERO E CONFIGURAÇÕES ÓTIMAS PARA ESTACAS HELICOIDAIS EM SOLO TROPICAL DE BAIXA RESISTÊNCIA}

\subsubsection{VERIFICAÇÃO DA CONFIGURAÇÃO ÓTIMA}

Pelas comparações entre o desempenho de estacas cilíndricas e cônicas (com diâmetros médios similares) com duas hélices (A2 e B2), e com três hélices (A3 e B3), mostradas na Figura 5.11e na Figura 5.16, observou-se que não existe vantagem significativa em termos de capacidade de carga para um dos tipos de configuração.

Porém, para instalar estaca helicoidal em solo tropical residual de baixa resistência com configuração cônica é necessária a aplicação de maior torque do que para estacas cilíndricas de mesmo diâmetro médio de hélices (Figura 5.8), o que é uma desvantagem para o modelo de estacas de hélices crescentes (cônica), pois não há ganhos no desempenho da estaca, apenas acréscimo de torque necessário a instalação e consequentemente no custo do uso da estaca.

Conclui-se então que o uso de estacas de hélices iguais (configuração cilíndrica) é mais vantajoso neste tipo de solo do que estacas com hélices crescentes (configuração cônica), mantendo-se o mesmo diâmetro médio.

\subsubsection{VERIFICAÇÃO DO NÚMERO ÓTIMO DE HÉLICES}

Para esta verificação, as hélices dos modelos de estacas testados foram instaladas de acordo com a sua posição nas mesmas profundidades (todas primeiras hélices na mesma profundidade, todas segundas hélices na mesma profundidade, e todas terceiras hélices na mesma profundidade). Neste caso, considerando-se a homogeneidade horizontal do terreno foi feita a verificação para os três casos abaixo:

Caso 1 - Estacas com hélices de mesmo diâmetro: neste caso, pela comparação dos resultados mostrados de capacidade de carga das estacas A1 (uma hélice), A2 (duas hélices) e A3 (três hélices), concluiu-se o seguinte: 
- O benefício da adição de uma segunda hélice à estaca de uma hélice A1 foi obtido pela diferença entre os valores de capacidade de carga das estacas A2 e A1 (considerando-se a homogeneidade do terreno no plano horizontal). Neste caso, a adição de uma segunda hélice de mesmo diâmetro aumentou a capacidade de carga em $72 \%$.

- O benefício da adição de uma terceira hélice à estaca de duas hélices A2 foi obtido pela diferença entre os valores de capacidade de carga das estacas A3 e A2 (considerando-se a homogeneidade do terreno no plano horizontal). Neste caso, a adição de uma terceira hélice de mesmo diâmetro aumentou a capacidade de carga em $44 \%$.

Caso 2 - Estacas com hélices crescentes, caso B (menor diâmetro médio de hélices): neste caso, pela comparação dos resultados mostrados de capacidade de carga das estacas B1 (uma hélice), B2 (duas hélices) e B3 (três hélices), concluiu-se o seguinte:

- Usando-se o mesmo procedimento citado no Caso 1 acima, a adição de uma segunda hélice de maior diâmetro (50 mm maior) à estaca de uma hélice B1 aumentou a capacidade de carga em $130 \%$.

- Usando-se o mesmo procedimento citado no Caso 1 acima, a adição de uma terceira hélice de maior diâmetro (50 mm maior que o da segunda hélice) à estaca de duas hélices B2 aumentou a capacidade de carga em $26 \%$.

Caso 3 - Estacas com hélices crescentes, caso C (maior diâmetro médio de hélices): neste caso, pela comparação dos resultados mostrados de capacidade de carga das estacas A1 (uma hélice), C2 (duas hélices) e C3 (três hélices), concluiu-se o seguinte:

- Usando-se o mesmo procedimento citado no Caso 1 acima, a adição de uma segunda hélice de maior diâmetro $(50 \mathrm{~mm}$ maior) à estaca de uma hélice A1 aumentou a capacidade de carga em $231 \%$.

- Usando-se o mesmo procedimento citado no Caso 1 acima, a adição de uma terceira hélice de maior diâmetro (50 mm maior que o da segunda hélice) à estaca de duas hélices C2 aumentou a capacidade de carga em $26 \%$.

Com base nestes resultados do efeito da adição de uma hélice na capacidade de carga à tração de estacas helicoidais, quanto ao número ótimo de hélices concluiu-se que: 
1. Para estaca helicoidal de configuração cilíndrica (hélices de mesmo diâmetro), neste tipo de terreno, a adição de uma terceira hélice contribui mais significantemente para a capacidade de carga da estaca do que para estacas de configuração cônica (hélices crescentes).

2. No caso das estacas com hélices crescentes (Casos 2 e 3 ) a adição da segunda hélice a uma estaca de uma hélice contribuiu mais à capacidade de carga da estaca do que no caso de estacas de configuração cilíndrica. Explica-se este fato pelo efeito da instalação no solo acima da segunda hélice que é minimizado nos Casos 2 e 3 comparando-se ao Caso 1.

3. A adição de uma terceira hélice com diâmetro crescente às estacas B2 e C2 não contribuiu com a capacidade de carga o quanto era esperado pelos métodos de cálculo. No caso de hélices maiores (Caso 3), a contribuição de uma terceira hélice foi ainda menor.

Por fim, com base nas conclusões supracitadas considera-se que o número ótimo de hélices para estacas instaladas no solo estudado depende da configuração e do diâmetro das mesmas. São necessários ainda mais ensaios para obter uma conclusão quanto ao número ótimo de hélices, no entanto, para estacas com hélices crescentes e de diâmetros maiores a adição de uma terceira hélice contribui pouco à capacidade de carga da estaca. 


\section{CAPITULO 6 - CONCLUSÕES}

Neste trabalho foi discutido o efeito da instalação e o desempenho de estacas helicoidais em solo tropical não saturado, poroso e estruturado através dos resultados de investigação de campo e ensaios de prova de carga a tração. Foram realizados ensaios de campo (SPT e CPT) e de laboratório (Umidade higroscópica) para caraterização da área em questão. Foram fabricadas 9 estacas metálicas helicoidais, com diferentes diâmetros e número de hélices especificamente para esta pesquisa, de forma a avaliar o efeito da configuração das mesmas na alteração da capacidade de carga a tração. Todas as estacas foram instaladas em mesmo perfil de solo, com mesma caracterização geotécnica e com a cota de assentamento em mesma profundidade, $10 \mathrm{~m}$. Logo, se chegaram às seguintes conclusões:

1. Os resultados da relação obtida com o quociente do torque de instalação medido com o $\mathrm{N}_{\text {SPT }}$ da área estudada apresentaram coerência com o perfil do solo, tanto na perfilagem quanto na compacidade/consistência do solo. Isso cria a possibilidade de uso do torque (através da correlação do torque de instalação com o perfil do ensaio SPT) como ensaio de investigação de subsolo, tendo mais um ensaio útil e interessante para o uso quando se opta pela solução em estaca helicoidal.

2. A hipótese de perturbação do solo com a instalação da estaca foi comprovada e o ensaio CPT foi capaz de averiguar esta modificação no solo, através dos resultados do atrito lateral, fs.

3. O método de capacidade de cargas individuais, apesar de obter resultados com valores acima do dobro da capacidade de carga à tração medida nos ensaios, foi o método que mais se aproximou aos resultados dos efeitos do acréscimo do número de hélices (no caso de acréscimo de segunda hélice) e diâmetro médio na capacidade de carga a tração deste tipo de estaca.

4. Estacas de mesmo diâmetro médio das hélices, neste solo tropical estruturado não saturado, possuem a mesma capacidade de carga à tração, independente da configuração das hélices (cônica ou cilíndrica). 
5. Estacas cônicas necessitam de maior torque de instalação do as estacas cilíndricas, mas neste solo tropical estruturado não saturado de baixa resistência não resultam em maior capacidade de carga.

6. Observando-se os resultados das comparações entre as estacas cônicas e cilíndricas de duas e de três hélices não existe vantagem significativa em termos de capacidade de carga para um dos dois tipos de configuração. No entanto, em termos de torque de instalação a configuração cônica requer maiores torques do que a cilíndrica.

7. A relação entre o ganho de resistência com o acréscimo de superfície resistente da hélice, com a perda de resistência do solo devido ao maior cilindro de solo perturbado durante a instalação é relevante na contribuição de acréscimos de capacidade de carga à tração devido acréscimo de números de hélices.

8. O efeito do acréscimo do diâmetro médio de uma estaca helicoidal de configuração cônica é vantajoso em relação a capacidade de carga à tração, pois a porcentagem do acréscimo da capacidade de carga é quase o dobro da porcentagem do acréscimo do diâmetro médio das hélices da estaca.

9. Por fim, para estacas neste tipo de solo de $\mathrm{N}_{\text {SPT }}$ com um máximo de 10 golpes $/ 30 \mathrm{~cm}$ não é recomendada a utilização dos valores de $\mathrm{K}_{\mathrm{T}}$ encontrados na literatura para a previsão da capacidade de carga com base no valor de torque de instalação.

No entanto, mais estudos são necessários para confirmar estes resultados, e estes estão sugeridos no CAPITULO 7 - . 


\section{CAPITULO 7 - RECOMENDAÇÕES PARA TRABALHOS FUTUROS}

- Refazer os ensaios para as condições distintas de espaçamento entre hélices, verificando o efeito do número de hélices para o caso de ruptura cilíndrica e para o caso de ruptura de capacidades individuais separadamente (S/D $<<3$ e S/D $>>3$ ).

- Recomenda-se para analisar o efeito da instalação das hélices no solo, o uso de ensaios CPT com hastes de menor diâmetro e mais sensíveis, em diferentes tipos de solos com diferentes resistências, para avaliar se fs o qc é alterado com a instalação.

- Mais ensaios com estacas de mesmo diâmetro médio, para validação das comparações e análises aqui realizadas.

- Uso de ensaios triaxiais e DTM para verificar melhor o efeito da instalação.

- Mais estudos e análises para o uso do torque de instalação como ensaio de investigação geotécnica.

- Retroanálise dos métodos para melhor calibração dos fatores de capacidade de carga à tração e dos coeficientes de pressão lateral em carga última. Aprofundando assim mais o conhecimento para os solos tropicais a fim de serem utilizados na melhoria dos métodos de previsão existentes. 


\section{REFERÊNCIAS BIBLIOGRÁFICAS}

ASEL-TECH (2010). Pipeline screw anchor system. Disponível em: < http://www.aseltech.com/products-anchor.html>. Acceso em: 13/03/2011.

ASSOCIAÇÃO BRASILEIRA DE NORMAS TÉCNICAS. NBR 6457. Amostras de solo Preparação para ensaios de compactação e ensaios de caracterização. Rio de Janeiro, 1986.

ASSOCIAÇÃO BRASILEIRA DE NORMAS TÉCNICAS. NBR 12131. Estacas - Prova de Carga Estática. Rio de Janeiro, 2006.

ASSOCIAÇÃO BRASILEIRA DE NORMAS TÉCNICAS. NBR 6122. Projeto e Execução de Fundações. Rio de Janeiro, 2010.

CARVALHO, I.P.G.D. (2007). Estudo teórico-experimental da capacidade de carga à tração e compressão de estacas metálicas helicoidais. 205 pp. Dissertação (Mestrado) Universidade Federal de Minas Gerais - UFMG, Belo Horizonte, 2007.

CHANCE A.B. Co. (1994). Helical pier foundation systems. Technical Manual, Centralia, Bulletin 01-9601.

CHANCE A.B. Co. (2003). Calculating Helical Screw Foundation Capacity. In Helical Screw Foundation System Design Manual for New Construction. Centralia, USA.

CHANCE A.B. Co. (2004). Encyclopedia of anchoring. Centralia, USA.

CLEMENCE, S.P.; CROUCH, L.K.; STEPHENSON, R.W. (1994). Prediction of Uplift Capacity for Helical Anchors in Sand. Proceedings, Second Geotechnical Engineering Conference, Cairo University.

CRHEA LOCALIZAÇÃO (2011). Site da Usp. Disponível em: < http://www.eesc.usp.br/shs/index.php?option=com_contenteview=categoryeid=22eItemid =18>. Acessado em: 08 /09/2011

De acordo com a Associação Brasileira de Normas Técnicas. NBR 6023 
DAS, B. M. (1990). “Earth Anchors”. Elsevier Science Publisher, New York, 241p.

GHALY, A.,HANNA, A. (1991). Experimental and theoretical studies on installation torque of screw anchors. Canadian Geotechnical Journal, v.28, n.3, p.353-364.

HOYT, R.,CLEMENCE, S. (1989). Uplift capacity of helical anchors in soil. In: ASCE, p.10191022

KNOWLEDGE, S.S. (2010). SCI Assessment of the Chance Helical Piling System. Berkshire, UK: Steel Constrution Institute Manual. 3.

KULHAWY, F.H. (1985). Uplift Behavior of Shallow Soil Anchors-An Overview. In: ASCE. p.1-25

LIVNEH, B.; EL NAGGAR, M.H. (2008). Axial Testing and Numerical Modeling of Square Shaft Helical Piles under Compressive and Tensile Loading. Canadian Geotechnical Journal, 45: 1142-1155.

LUTENEGGER, A.J., (2009). Cylindrical Shear or Plate Bearing? - Uplift Behavior of MultiHelix Screw Anchors in Clay. Contemporary Issues in Deep Foundations, ASCE, GSP 185 , pp. 456-463.

LUTENEGGER, A. J. (2011). Behavior of Multi-Helix Screw Anchors in Sand. 14th PanAmerican Conference on Soil Mechanics and Geotechnical Engineering,Toronto, Canadá.

MERIFIELD, R.S. (2011). The ultimate uplift capacity of multi-plate helical type anchors in clay. Journal of Geotechnical and Geoenvironmental Engineering, 137(7), 704-716.

MERIFIELD, R.S. SMITH, C.C. (2010). The ultimate uplift capacity of multi-plate strip anchors in undrained clay. Computers and Geotechnics 37 (2010) 504-514. Elsevier.

MEYERHOF, G. G., (1976) Bearing Capacity and Settlement of Pile Foundations, Journal of the Geotechnical Engineering Division, Proceedings of the American Society of Civil Engineers, Vol. 102, No. GT3, March 1976. 
MEYERHOF, G.G.; ADAMS, J.I (1968).The ultimate uplift capacity of foundations. Canadian Geotechnical Journal, Vol 5, No. 4, Nov. 1968, pp. 224-244.

MITSCH, M.P.,CLEMENCE, S.P. (1985). The uplift capacity of helix anchors in sand. In: ASCE. p.26-47

MOONEY, J.S.; ADAMCZAK JR., S.; CLEMENCE, S.P.(1985) Uplift Capacity of Helical Anchors In Clay and Silt. In: Uplift Behavior of Anchor Foundations in Soil, 1985, Detroit. Detroit: Proceedings of a session sponsored by the Geotechnical Engineering Division of the American Society of Civil Engineers, 1985, p. 48-72

NIROUMAND, H., KASSIM, K.A., GHAFOORIPOUR, A., NAZIR, R. E CHUAN, H.S. (2012) Performance of Helical Anchors in sand. The Electronic Journal of Geotechnical Engineering. Vol. 17, Bund.R.

PERKO, H.A. (2009). Helical Piles: A Practical Guide to Design and Installation. Dan Brow. Wiley.

PERKO, H. A.; RUPIPER, S.J. (2000). “Helix pier engineering handbook 2000”. Ingal Precision Foundations, INC. Worldwide Helix Pier Distributors.

RAO, S. N.; Prasad, M.D.; Shetty, M.D.; Joshi, V.V. (1989). "Uplift capacity of screw pile anchors". Geotechnical Engineering, v.20, n.2, p. 139-159.

ROBERTSON, P. K.; CAMPANELlA, R. G.; GILlESPIE, D.; GRIEG, J. (1986). Use of piezometer cone data, In-Situ 86, ASCE Spe-cialty Conference, Blacksburg, Virginia.

SAKR, M., (2009), Performance of Helical Piles in Oil Sand. Canadian Geotechnical Journal, 46: 1046-1061.

SILVA, D. P. (2005) Influência da contaminação por cloreto de cobre na resistência ao cisalhamento de solos utilizados em liners. São Carlos. 136p. Dissertação de mestrado. EESC-USP.

De acordo com a Associação Brasileira de Normas Técnicas. NBR 6023 
TSUHA, C. (2007). Modelo teórico para controle da capacidade de carga à tração de estacas metálicas helicoidais em solo arenoso. 253 pp. Tese (Doutorado) - Universidade de São Paulo, São Carlos, São Paulo, 2007.

TSUHA, C.H.C., AOKI, N., RAULT, G., THOREL, L. AND GARNIER, J. (2007). Physical modeling of helical pile anchors. International Journal of Physical Modelling in Geotechnics, 7 (4): 1-12.

TSUHA, C.H.C. AND AOKI (2010). Relationship between installation torque and uplift capacity of deep helical piles. Canadian Geotechnical Journal, 47(6): 635-647.

TSUHA, C. H. C. E AOKI, N. (2011) Quality Control f Helical Piles in sand. Pan-Am CGS Geotechnical Conference. Toronto, Canada.

TSUHA, C.H.C.; AOKI, N.; RAULT, G.; THOREL, L.; GARNIER, J. (2012). Evaluation of the efficiencies of helical anchor plates in sand by centrifuge model tests. Canadian Geotechnical Journal (Print), v. 49, p. 1102-1114, 2012.

ZHANG, D.J.Y. (1999). Predicting capacity of helical screw piles in Alberta soils. M.S. thesis, Department of Civil and Environmental Engineering, University of Alberta, Edmonton, Alta. 


\section{APÊNDICE A - CALIBRAÇÃO DOS EQUIPAMENTOS}

\section{A.1 Calibração do Mandril hidráulico}

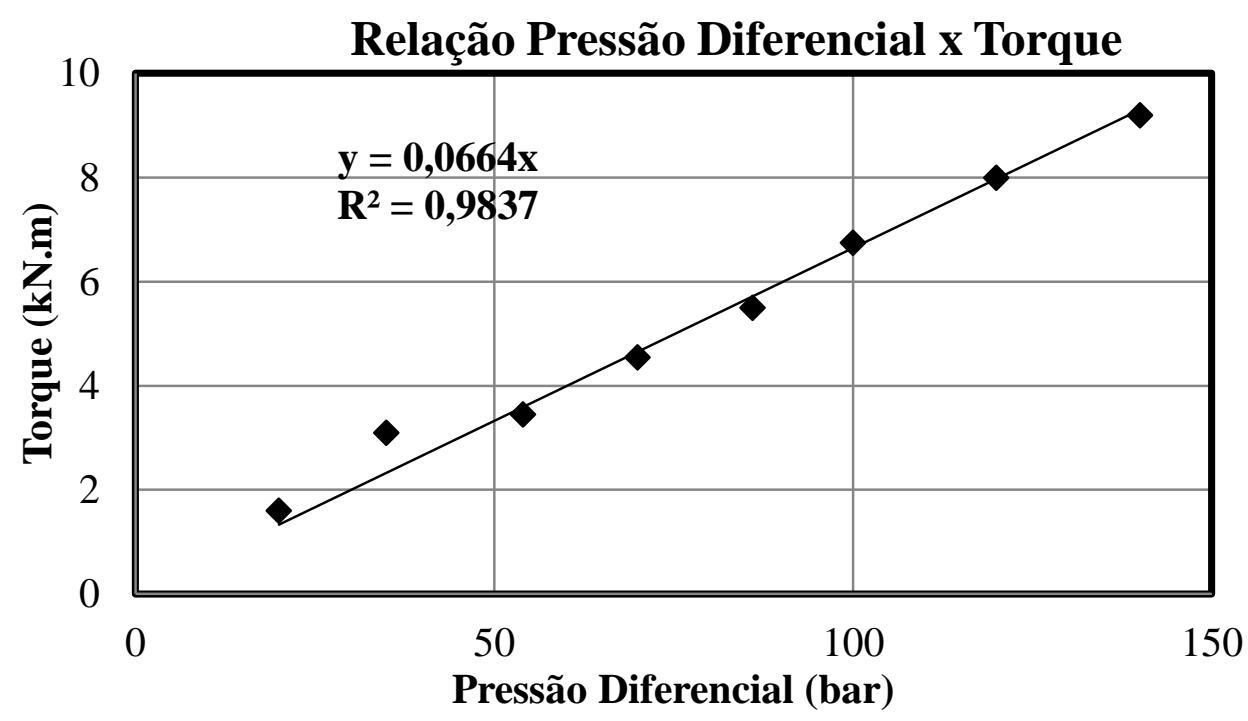

Figura 5.19: Calibração do Mandril de aplicação da carga

A.2 Calibração da aquisição de dados da célula de carga

Relação do indicador de força da célula de carga vs a carga equivalente

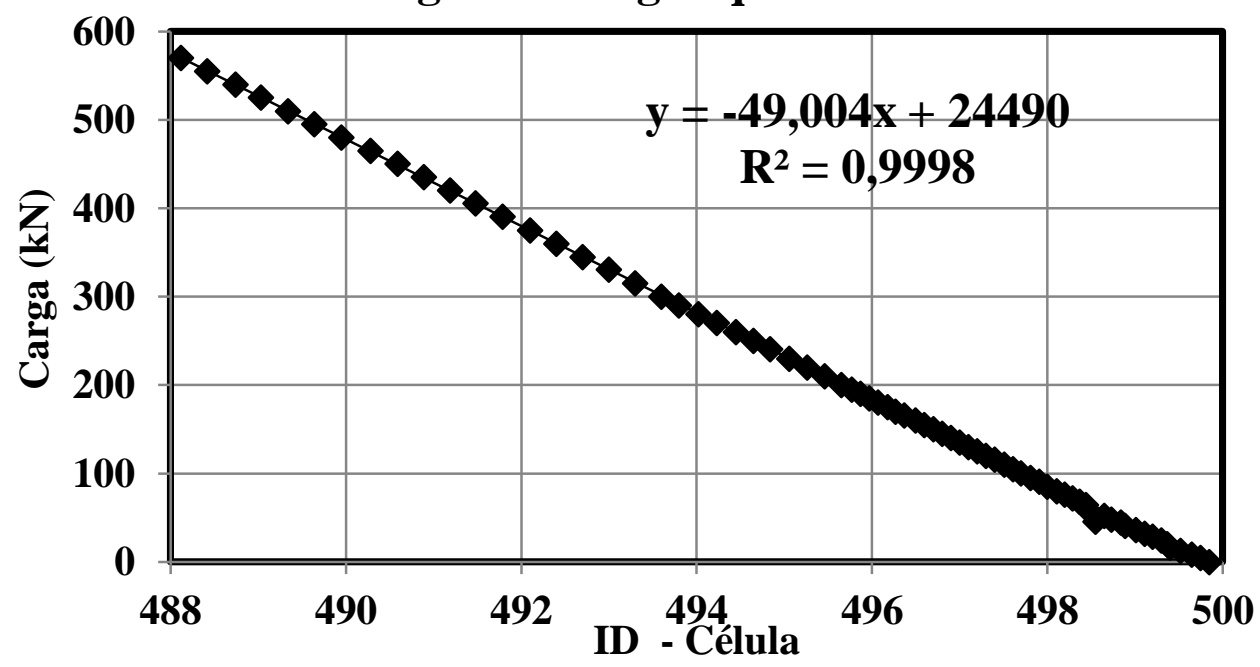

Figura 5.20: Calibração da célula de carga 


\section{APÊNDICE B - RESULTADOS DE MEDIÇÕES}

\section{B.1 Registro das Pressões Diferenciais na Instalação}

Tabela 5.10: Pressões diferenciais registradas durante a instalação, medidas a cada meio metro.

\begin{tabular}{|c|c|c|c|c|c|c|c|c|c|c|c|}
\hline \multirow{2}{*}{$\begin{array}{c}\text { Prof. } \\
(\mathbf{m})\end{array}$} & \multicolumn{10}{|c|}{ Pressão Diferencial (Bar) } \\
\cline { 2 - 13 } & $\mathbf{A 1}$ & $\mathbf{A 2}$ & $\mathbf{A 3}$ & $\mathbf{B 1}$ & $\mathbf{B 2}$ & $\mathbf{B 3}$ & $\mathbf{C 2}$ & $\mathbf{C 3}$ & $\begin{array}{c}\text { B1 } \\
\text { em R }\end{array}$ & $\begin{array}{c}\mathbf{R} . \\
\mathbf{B 1}\end{array}$ \\
\hline $\mathbf{0 , 5}$ & 33 & 46 & 50 & 36 & 44 & 76 & 42 & 52 & 55 & & \\
\hline $\mathbf{1 , 0}$ & 33 & 37 & 46 & 42 & 39 & 64 & 42 & 48 & 55 & & \\
\hline $\mathbf{1 , 5}$ & 34 & 41 & 48 & 40 & 38 & 75 & 46 & 60 & 58 & & \\
\hline $\mathbf{2 , 0}$ & 32 & 42 & 49 & 44 & 38 & 74 & 56 & 62 & 74 & & 20 \\
\hline $\mathbf{2 , 5}$ & 32 & 48 & 52 & 60 & 37 & 70 & 62 & 62 & 80 & & 20 \\
\hline $\mathbf{3 , 0}$ & 34 & 44 & 44 & 49 & 42 & 66 & 59 & 57 & 64 & & 15 \\
\hline $\mathbf{3 , 5}$ & 36,5 & 46 & 52 & 48 & 41 & 70 & 65 & 67 & 75 & 45 & 25 \\
\hline $\mathbf{4 , 0}$ & 37,8 & 48 & 48 & 54 & 45 & 72 & 71 & 69 & 79 & 41 & 33 \\
\hline $\mathbf{4 , 5}$ & 38,5 & 48 & 57 & 63 & 45 & 74 & 74 & 70 & 82 & 41 & 36 \\
\hline $\mathbf{5 , 0}$ & 45 & 45 & 53 & 58 & 49 & 65 & 75 & 70 & 86 & 40 & 37,5 \\
\hline $\mathbf{5 , 5}$ & 45 & 54 & 59 & 56 & 52 & 72 & 86 & 78 & 86 & 47 & 37,5 \\
\hline $\mathbf{6 , 0}$ & 49 & 53 & 65 & 70 & 53 & 77 & 88 & 79 & 94 & 48 & 39 \\
\hline $\mathbf{6 , 5}$ & 47 & 60 & 69 & 75 & 59,5 & 75 & 86 & 82 & 97 & 53 & 46 \\
\hline $\mathbf{7 , 0}$ & 55 & 52 & 54 & 80 & 60 & 73 & 84 & 84 & 99 & 47 & 46 \\
\hline $\mathbf{7 , 5}$ & 55 & 56 & 67 & 63 & 58 & 75 & 92 & 87 & 97 & 54 & 55 \\
\hline $\mathbf{8 , 0}$ & 58 & 65 & 68 & 80 & 56,5 & 76 & 97 & 90 & 107 & 57 & 50 \\
\hline $\mathbf{8 , 5}$ & 62 & 64 & 73 & 96 & 68 & 78 & 96 & 82 & 107 & 60 & 46 \\
\hline $\mathbf{9 , 0}$ & 66 & 69 & 67 & 95 & 68 & 74 & 98 & 87 & 112 & 55 & 34 \\
\hline $\mathbf{9 , 5}$ & 70 & 71 & 77 & 86 & 66 & 76 & 95 & 85 & 113 & 60 & 52 \\
\hline $\mathbf{1 0 , 0}$ & 75,5 & 69 & 73 & 77 & 66 & 76 & 92 & 90 & 105 & 67,5 & 42 \\
\hline
\end{tabular}




\section{ANEXO A - RELATÓRIO DO ENSAIO DE SONDAGEM DE SIMPLES RECONHECIMENTO}

Vai anexo o arquivo com o relatório de sondagem realizado pela SONDOBASE, empresa terceirizada para executar os ensaios SPT. 


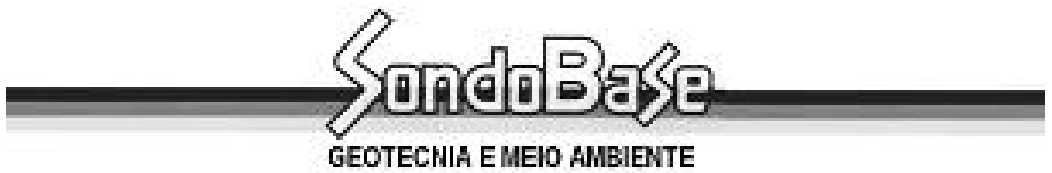

À

THIAGO DA COSTA SANTOS, ENG. ${ }^{\circ}$

Prezados Senhores,

Apresentamos abaixo, os resultados obtidos nos trabalhos de sondagem realizados para Área de estudo, situado na Estrada do Broa, km 1 - São Carlos - SP

Anexos:

1) A locação dos furos de sondagem em planta;

2) A seção provável ou perfil do subsolo; e

3) Os valores de S.P.T. nas cotas respectivas.

Sondagem:

Início: 27/07/11

Término: 30/07/11

Tipo: "Standard Penetration Test" (S.P.T.)

Denomina-se "Standard Penetration Test" (S.P.T.) o número de golpes dados com um peso padrão, caindo em queda livre, de uma altura constante, necessários para a penetração de um amostrador padrão à profundidade de 45 centímetros $(15+15+15 \mathrm{~cm})$, sendo que a leitura é feita somando o número de golpes dos dois últimos 15 centímetros (30 finais).

Observações:

a. O nível d'água encontra-se marcado na seção ou perfil de cada furo de sondagem. Recomenda-se que o nível d'água seja confirmado através da abertura de um poço de maior diâmetro na época da execução dos trabalhos de engenharia, devido às possíveis variações do mesmo, em função das características do solo e das condições climáticas.

b. A seção do subsolo indicada no perfil representa apenas a sequência provável das camadas entre os pontos sondados. Para amostragem das camadas foram obedecidas as determinações da ABNT, estando o material coletado no amostrador à disposição dos interessados pelo tempo de sessenta (60) dias, conforme o prescrito por esta associação.

Serviços Executados:

a. Furos de sondagem realizados : 03

b. Metros lineares perfurados : 36,61

c. Número de amostras coletadas : 38,00

Cordialmente,

Cláudio Rodrigues dos Santos

ENG $^{\circ}$ CIVIL - CREA 5061291419/D 


\section{LOCAÇÃO DOS FUROS DE SONDAGEM}
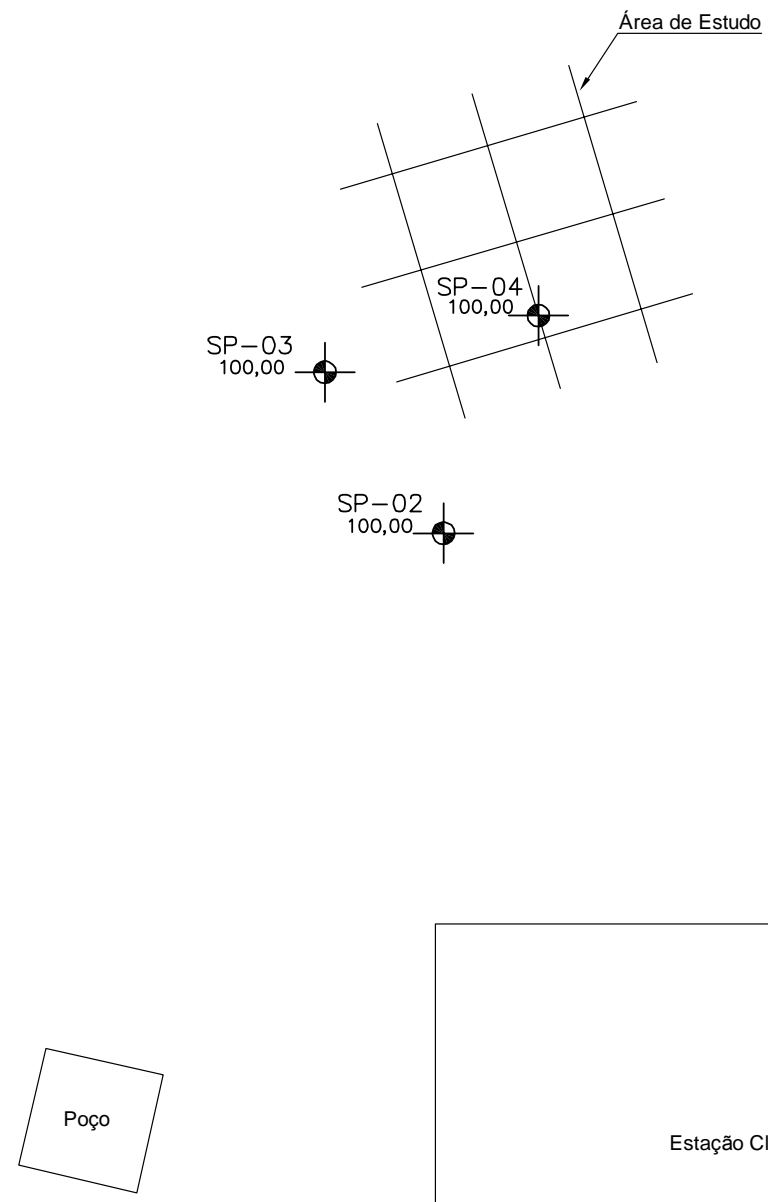

Estação Climatológica

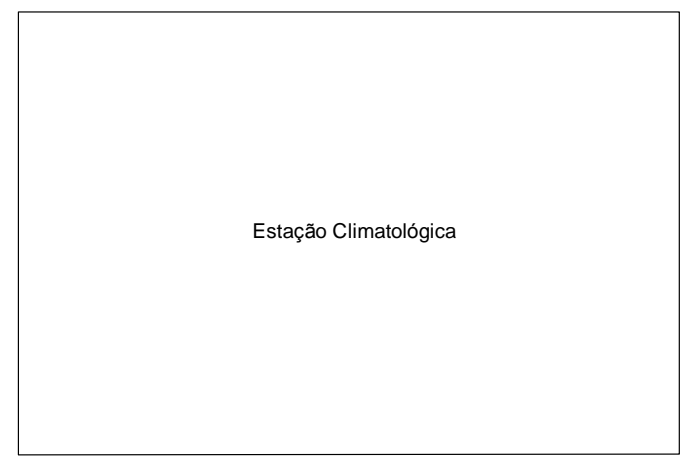

OBS: - Medidas e cotas em metros

- Locação dos furos determinada pelo cliente

Escala 1:400

- Cotas fornecidas pelo cliente

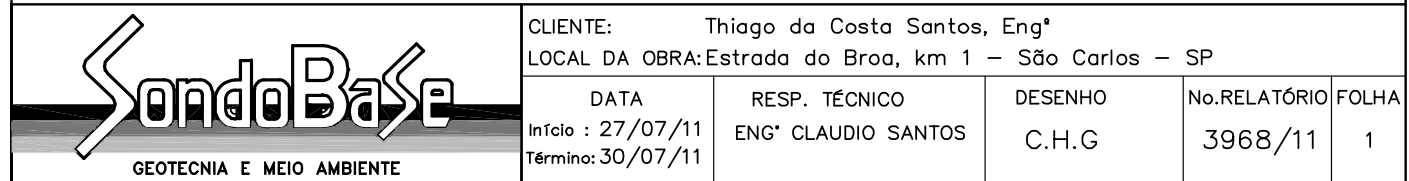




\begin{tabular}{|c|c|c|}
\hline 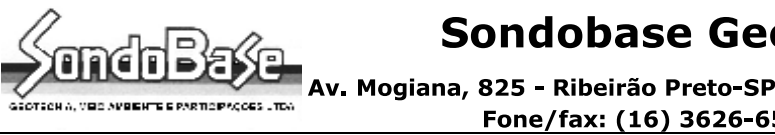 & a e Meio & iente \\
\hline 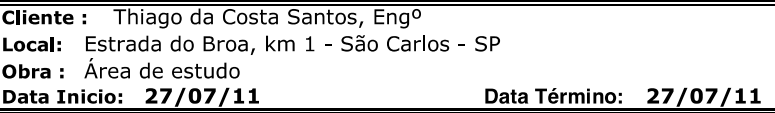 & SP & $\begin{array}{c}\text { Cota: } \\
100,00\end{array}$ \\
\hline
\end{tabular}

\begin{tabular}{|c|c|c|c|c|c|c|c|c|c|}
\hline \begin{tabular}{l||} 
cota \\
$(\mathrm{m})$
\end{tabular} & NA & $\begin{array}{l}\text { Prof. Da } \\
\text { camada }\end{array}$ & Amostras & Golpes & $\begin{array}{l}\mathbf{S} \\
P \\
T\end{array}$ & 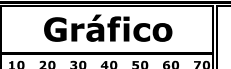 & \multicolumn{3}{|c|}{ Classificação do Subsolo } \\
\hline$=$ & & & $\mathbf{0}$ & \begin{tabular}{|c||ccc}
- & - & \\
15 & 15 & 1 \\
1
\end{tabular} & $-\mid$ & & & & \\
\hline$=$ & & & 1 & \begin{tabular}{l|l|l}
1 & 1 & 1 \\
& 2 & 1
\end{tabular} & 12 & & & & \\
\hline$=$ & & & 2 & \begin{tabular}{c||c|cc}
1 & 1 & 2 \\
\end{tabular} & 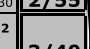 & & & & \\
\hline$=$ & & & & \begin{tabular}{l|||ll}
15 & 15 & 2 \\
2 & 1 & 2
\end{tabular} & \begin{tabular}{l||l|}
25 & $3 / 40$ \\
2 &
\end{tabular} & & & & \\
\hline$=$ & & & 3 & \begin{tabular}{ll|ll}
20 & 2 \\
20 & 2 & 2 \\
2
\end{tabular} & 20 & & $\begin{array}{l}\text { Argila muito arenosa po } \\
\text { mole a m }\end{array}$ & $\begin{array}{l}\text { ouco siltosa, v } \\
\text { hédia. - Colúvi }\end{array}$ & melha, muito \\
\hline 95 = & & & 4 & \begin{tabular}{|l||l|l}
2 & 2 & 3 \\
15 & 15 & 1 \\
\end{tabular} & 5 & & & & \\
\hline$=$ & & & 5 & \begin{tabular}{|l||ll}
2 & 2 & 3 \\
15 & 15 & 1
\end{tabular} & $\begin{array}{c}3 \\
15\end{array}$ & & & & \\
\hline$=$ & & & 6 & \begin{tabular}{|l||ll}
3 & 4 & 4 \\
15 & & 4 \\
15 & 1 &
\end{tabular} & 4 & & & & \\
\hline$=$ & & 7,45 & 7 & 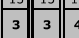 & 4 & & & & \\
\hline$=$ & & & & \begin{tabular}{l||l|l}
15 & 15 & 1 \\
3 & 2 & 3
\end{tabular} & 7 & & Argila muito arenosa pou & uco siltosa, co & pedregulhos, \\
\hline$=$ & & 9,00 & 8 & \begin{tabular}{c||c||c|c}
3 & 2 & 3 \\
15 & 15 & 1 \\
1
\end{tabular} & 5 & & variegada (verme & elha), média. & \\
\hline $90=$ & & & 9 & \begin{tabular}{|l|l|l}
3 & 3 & 3 \\
15 & 15 & 1 \\
1 &
\end{tabular} & \begin{tabular}{c|c}
4 \\
15
\end{tabular} & & & & \\
\hline$\exists$ & & & 10 & \begin{tabular}{|l||l|l}
3 & 3 & 6 \\
15 & 15 & 1
\end{tabular} & $\begin{array}{c}6 \\
15 \\
15\end{array}$ & 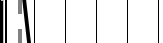 & & & \\
\hline$=$ & & & 11 & \begin{tabular}{|c||c|c} 
& 2 & \\
18 & 12 & 1 \\
\end{tabular} & \begin{tabular}{|l|l|}
4 & \\
15 & $6 / 27$ \\
\end{tabular} & 1 & $\begin{array}{l}\text { Silte arenoso, com eve } \\
\text { variegado (amarelo), pou }\end{array}$ & $\begin{array}{l}\text { entuais fragme } \\
\text { uco compacto }\end{array}$ & $\begin{array}{l}\text { tos de rocha, } \\
\text { medianamente }\end{array}$ \\
\hline$=$ & & & 12 & \begin{tabular}{|l||l|l}
2 & 3 & 4 \\
15 & 15 & 1 \\
15
\end{tabular} & \begin{tabular}{|l|l|}
$4 / 32$ \\
717
\end{tabular} & & | compacto. - Sol & lo Residual de & \\
\hline$\exists$ & 胥 & & 13 & \begin{tabular}{c||c|c}
2 & 3 & 4 \\
15 & 1 & 1 \\
15 &
\end{tabular} & \begin{tabular}{|l|l|}
4 & 7 \\
15
\end{tabular} & & & & \\
\hline 85 & ¿ & 14,40 & 14 & \begin{tabular}{|l|||c|c|} 
& $\mathbf{6}$ & 5 \\
15 & 15 & 1
\end{tabular} & \begin{tabular}{l|l|}
57 & \\
10 & $63 / 25$ \\
\end{tabular} & 1 & Rocha ou Matacão - I & Impenetráve & Percussão \\
\hline$\exists$ & $\omega$ & & 15 & & & & & & \\
\hline$=$ & 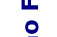 & & 16 & & & & & & \\
\hline$\exists$ & $\begin{array}{l}\mathbf{z} \\
\ddot{z}\end{array}$ & & 17 & & & & & & \\
\hline$\exists$ & & & 18 & & & & & & \\
\hline$=$ & & & 19 & & & & & & \\
\hline$=$ & & & 20 & & & & & & \\
\hline$=$ & & & 21 & & & & & & \\
\hline$=$ & & & 22 & & & & & & \\
\hline$\exists$ & & & 23 & & & & & & \\
\hline$=$ & & & 24 & & & & & & \\
\hline$\exists$ & & & 25 & & & & & & \\
\hline$\exists$ & & & 26 & & & & & & \\
\hline$\exists$ & & & 27 & & & & & & \\
\hline-1 & & & 28 & & & & & & \\
\hline & & & 29 & & & & & & \\
\hline & & & 30 & & & -1 & & & \\
\hline & & & & & & & & & \\
\hline NA INI & CIAL & & NFE & $27 / 7 /$ & /2011 & NA FINAL $(m)$ & $27 / 7 / 2011$ & Sondador: & A. Santos \\
\hline $\begin{array}{l}\text { Reves } \\
\text { Tr. Ca }\end{array}$ & $\begin{array}{l}\text { timer } \\
\text { vadei }\end{array}$ & 0,00 & $\begin{array}{l}\mathbf{a} \\
\mathbf{a}\end{array}$ & & & & & \begin{tabular}{|l|} 
Relatório: \\
\end{tabular} & $3968 / 11$ \\
\hline $\begin{array}{l}\text { Tr. He } \\
\text { Lavag }\end{array}$ & $\begin{array}{l}\text { licoid } \\
\text { em }\end{array}$ & 1,00 & $\begin{array}{l}\mathbf{a} \\
\mathbf{a}\end{array}$ & & & Eng. MSC. & tecnia Claudio Santos & Folha & 2 \\
\hline
\end{tabular}

PDF created with pdfFactory trial version www.pdffactory.com 


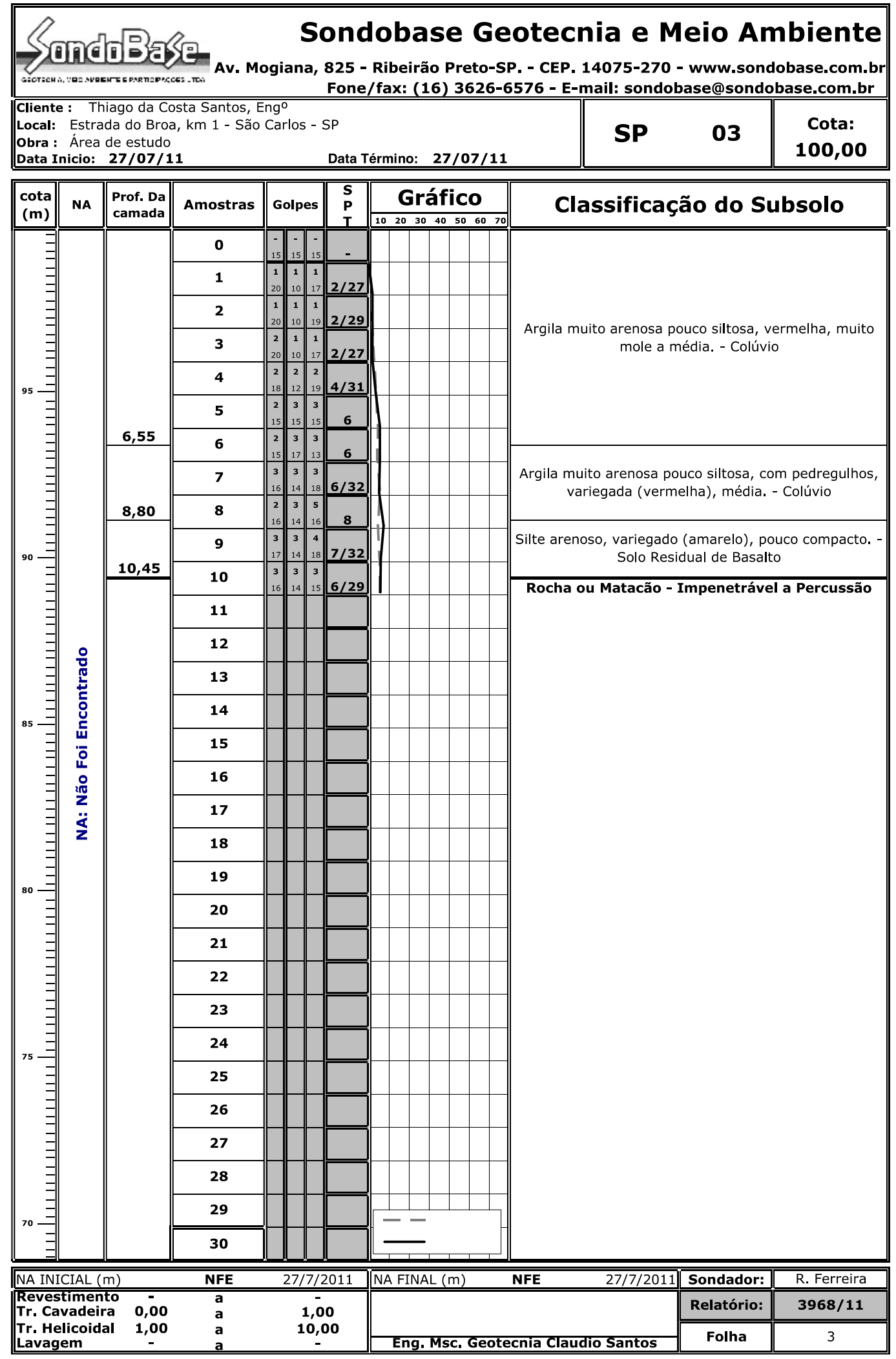

PDF created with pdfFactory trial version www.pdffactory.com 


\begin{tabular}{|c|c|c|}
\hline 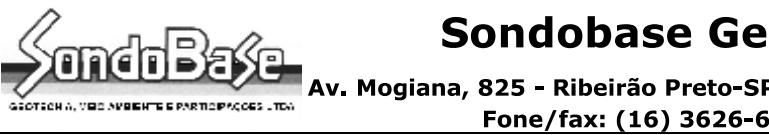 & a e Meio & jiente \\
\hline 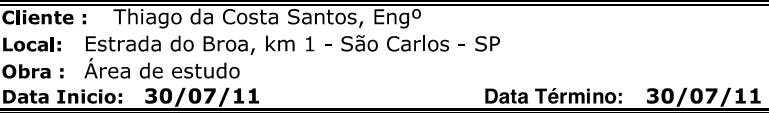 & SP & $\begin{array}{c}\text { Cota: } \\
100,00\end{array}$ \\
\hline
\end{tabular}

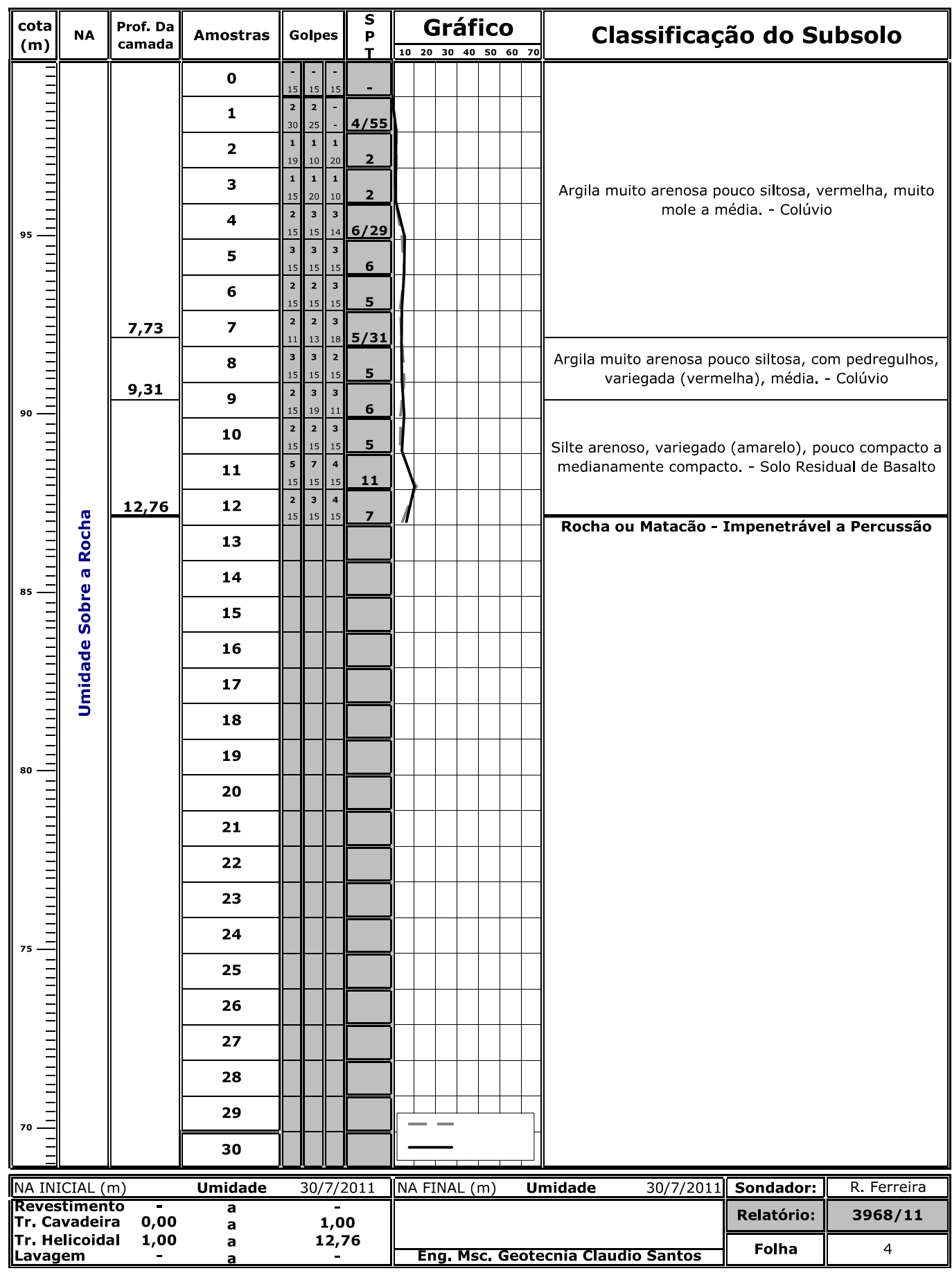

PDF created with pdfFactory trial version www.pdffactory.com 


\section{ANEXO B - PROJETO DE FABRICAÇÃO DAS ESTACAS METÁliCAS HELICOIDAIS}

Vai anexo os projetos das estacas metálicas helicoidais com seus componentes, helicoides, conexões, mandril e encaixes. 


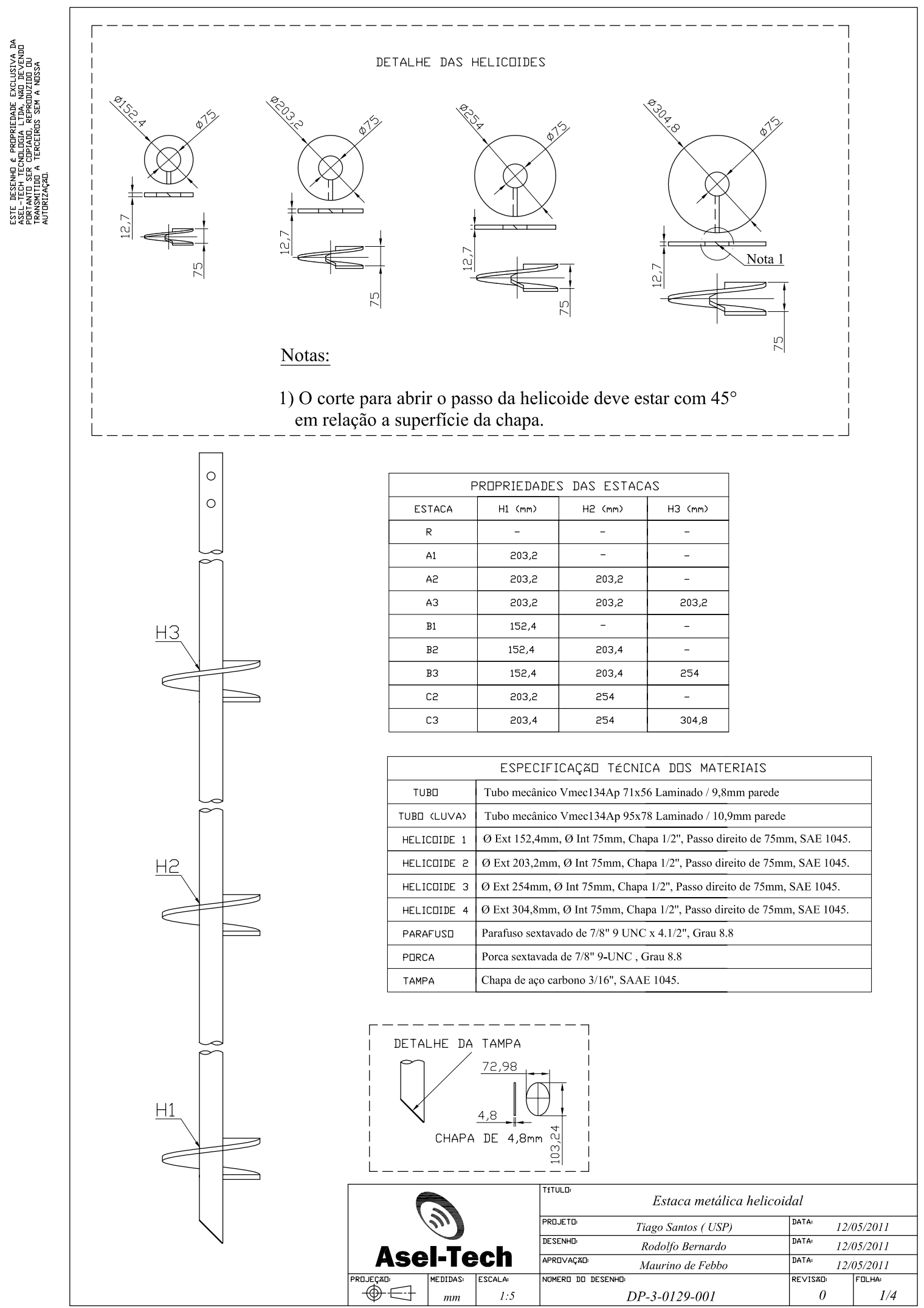




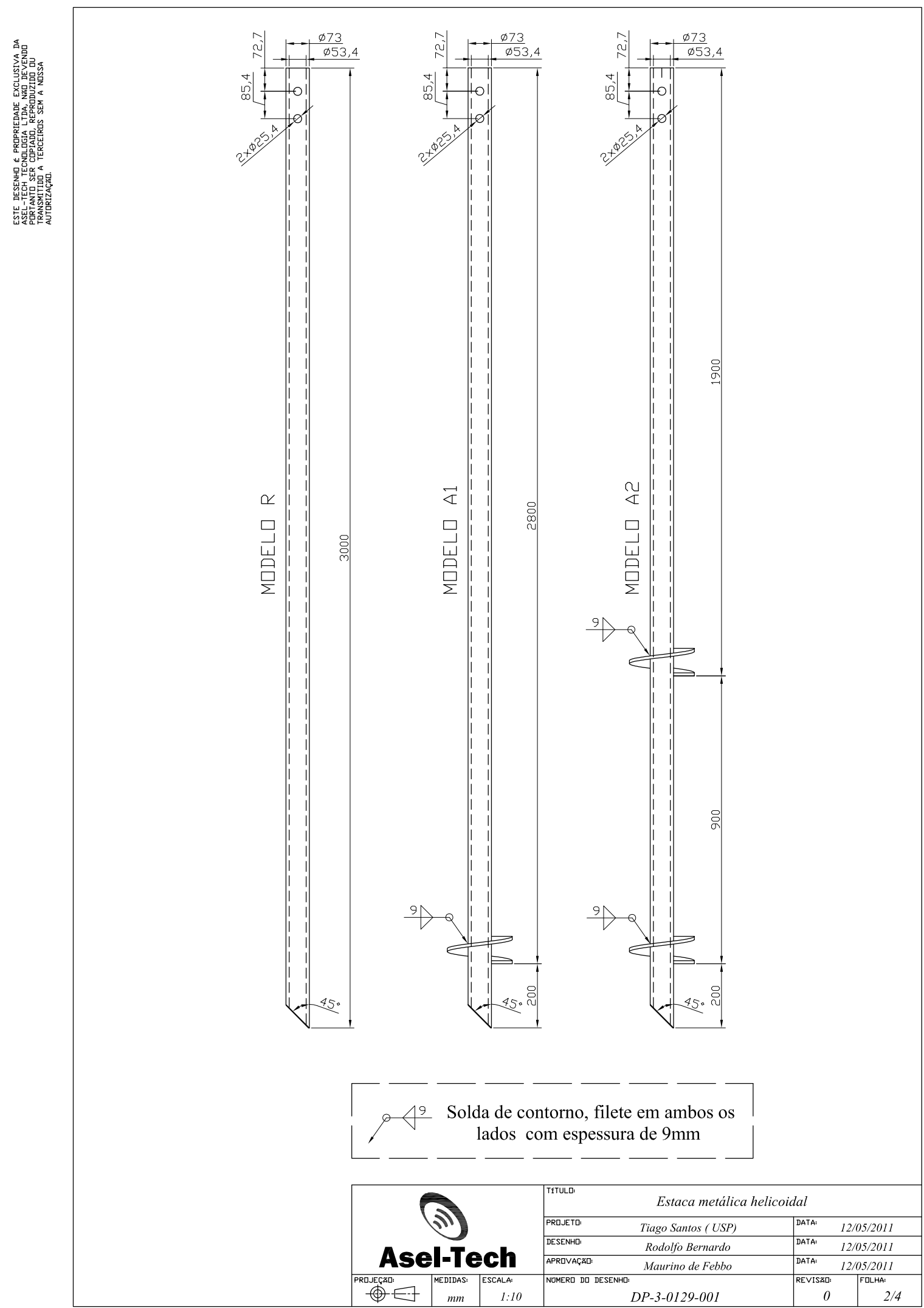




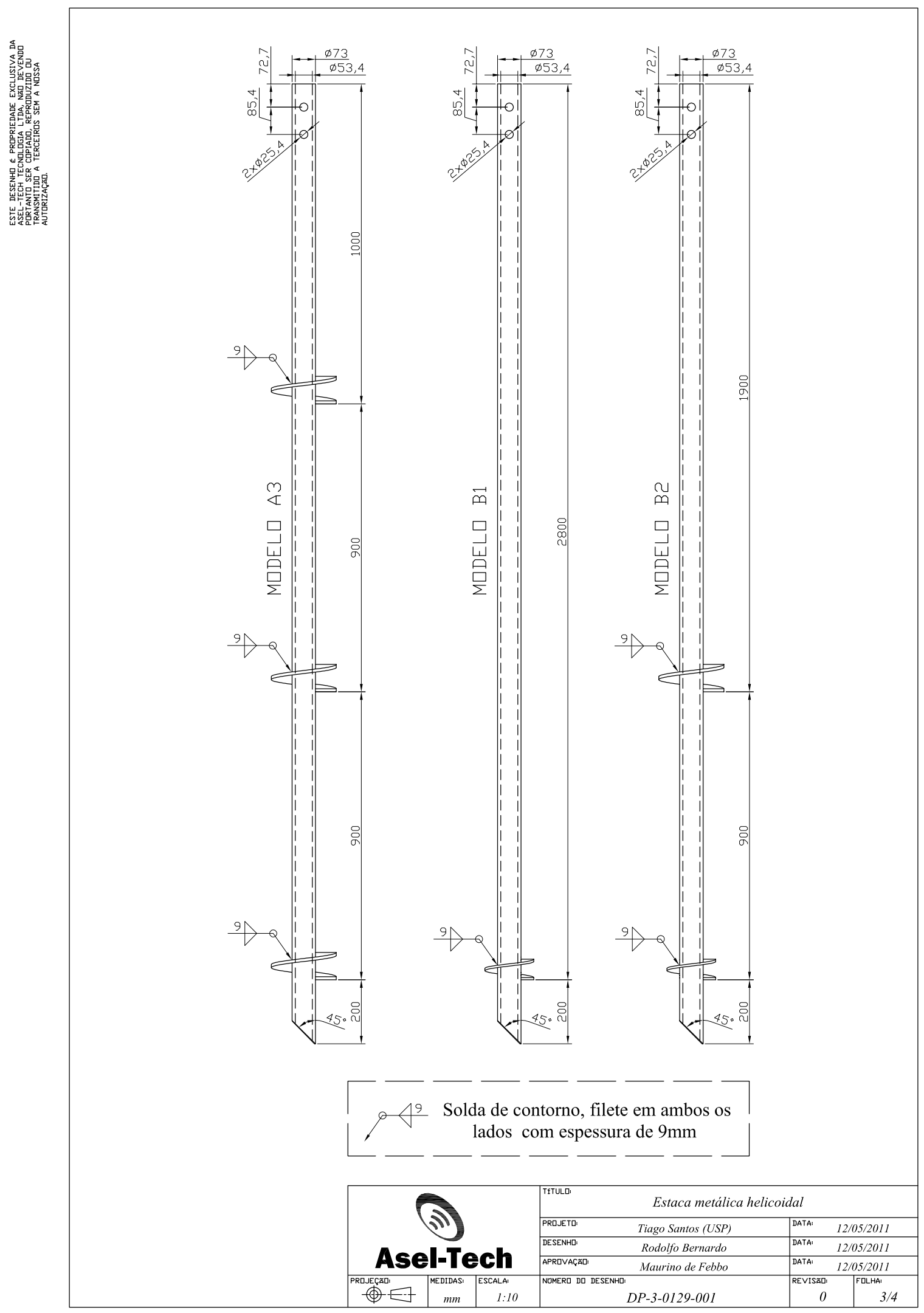




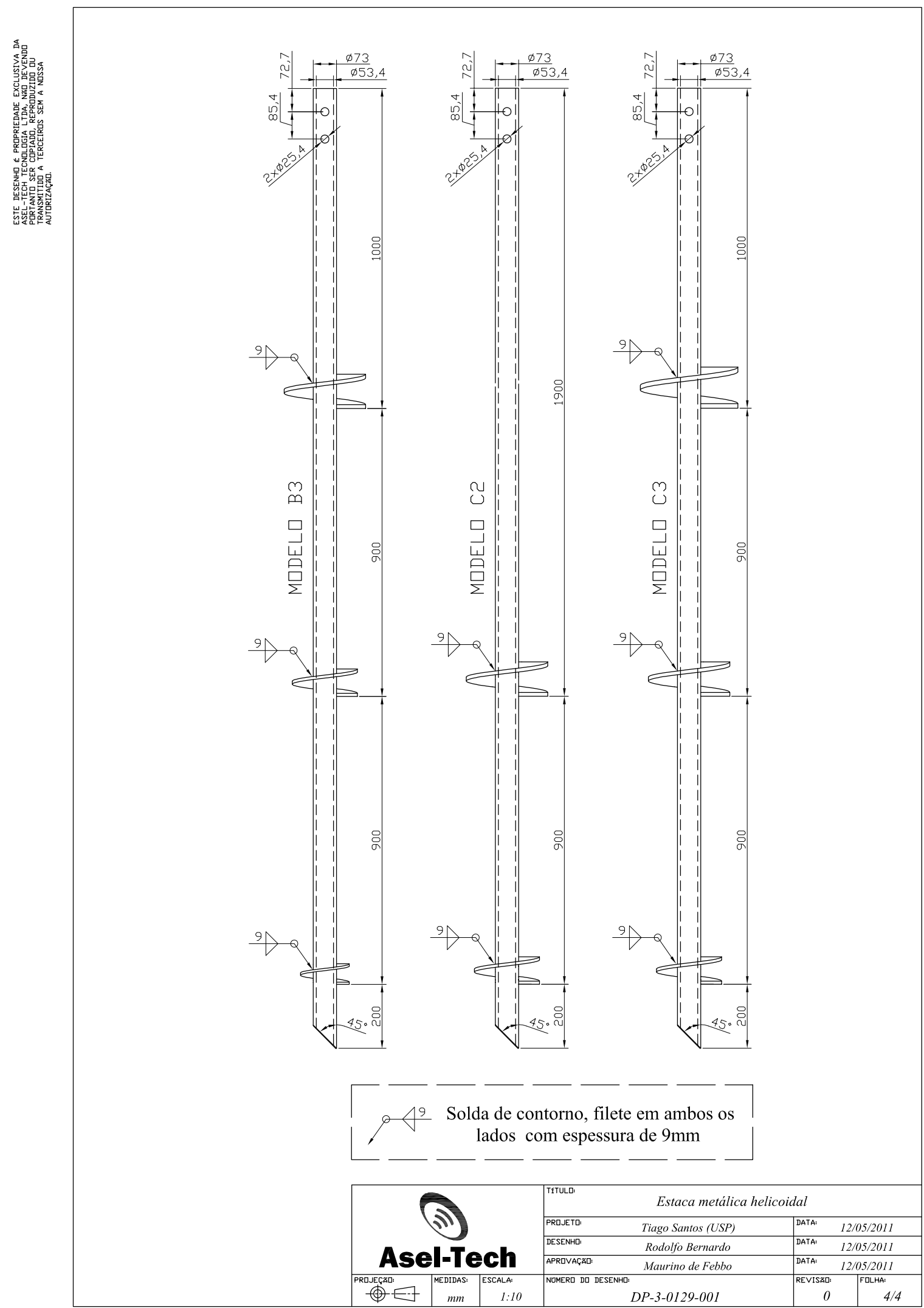




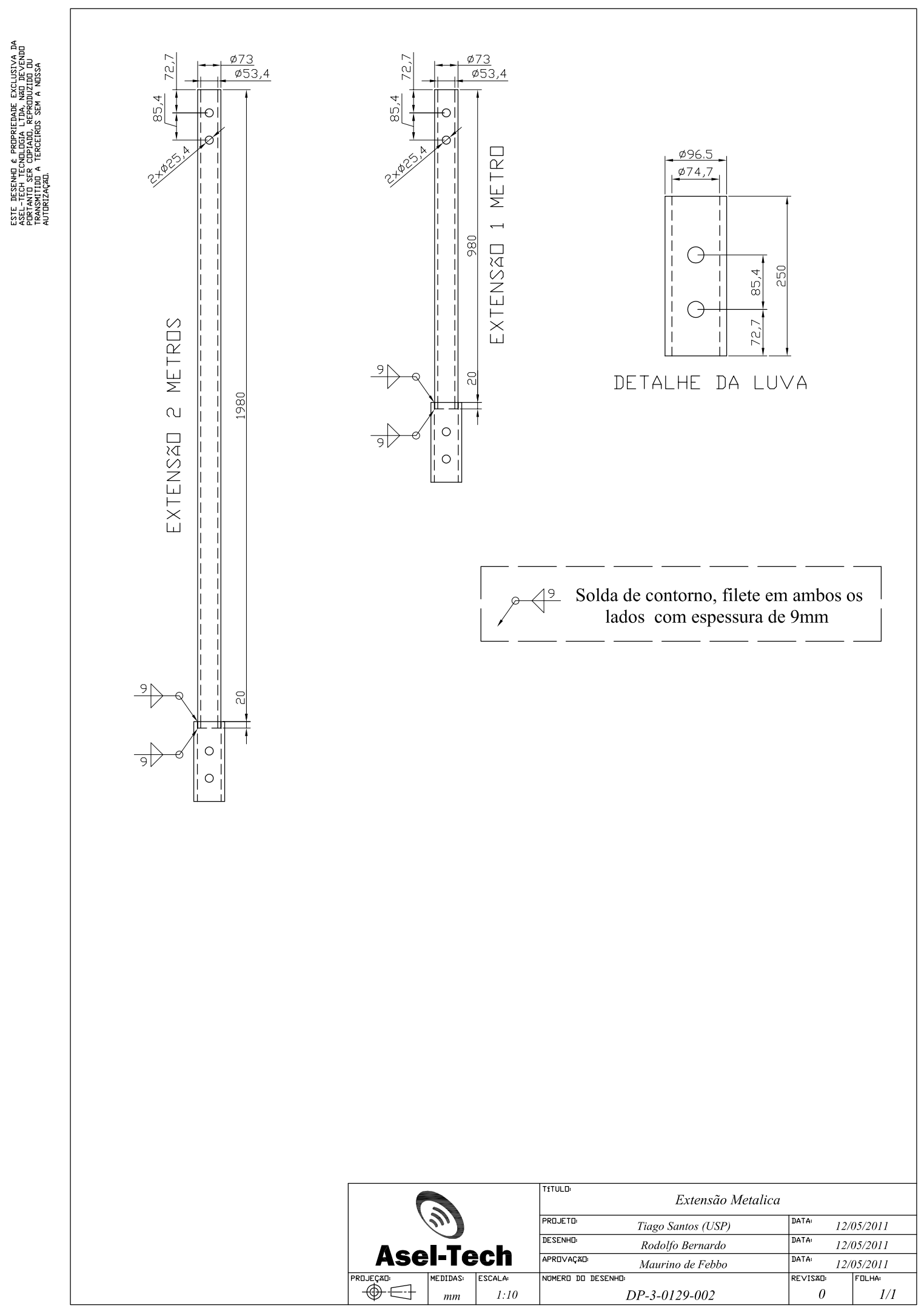




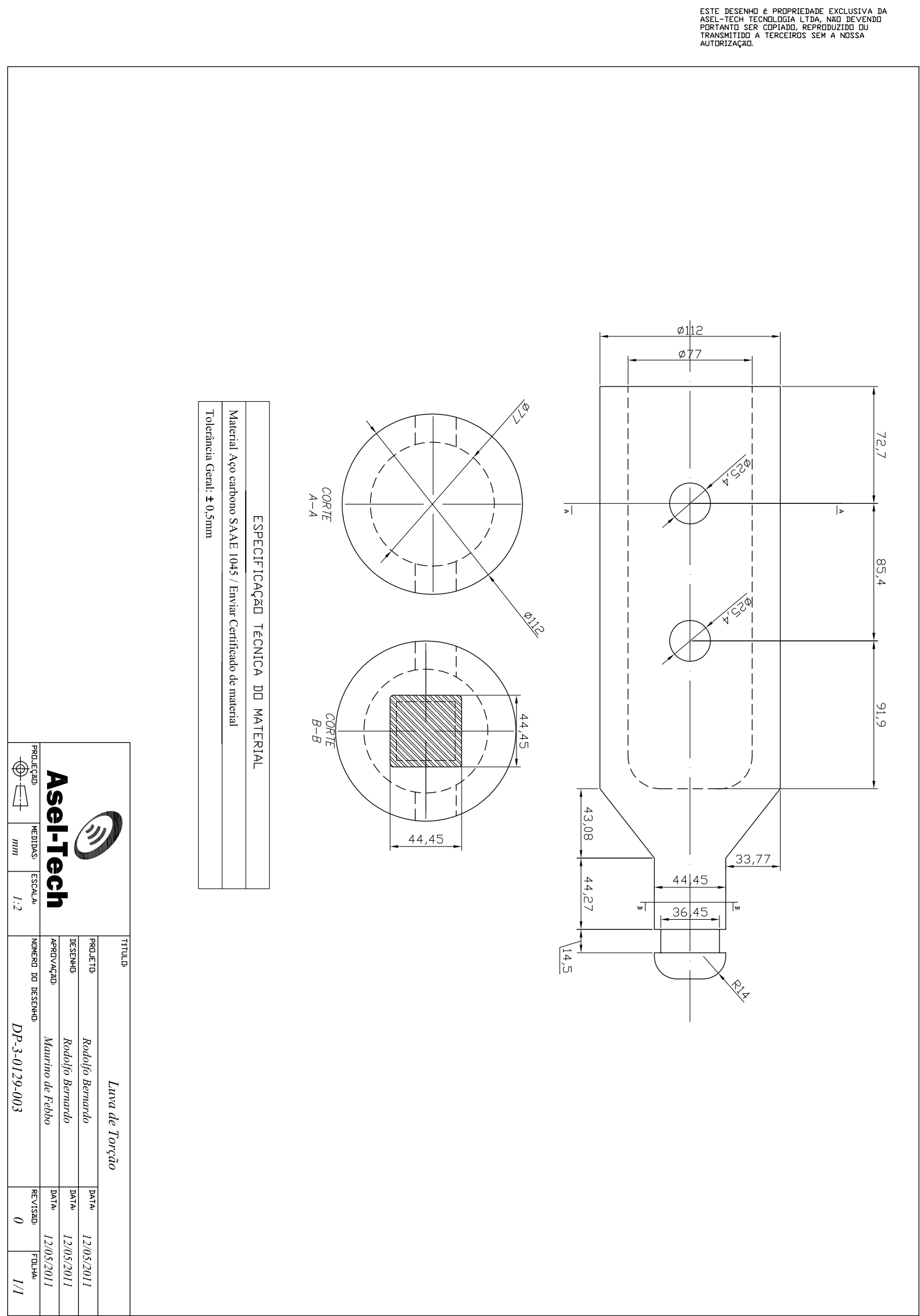




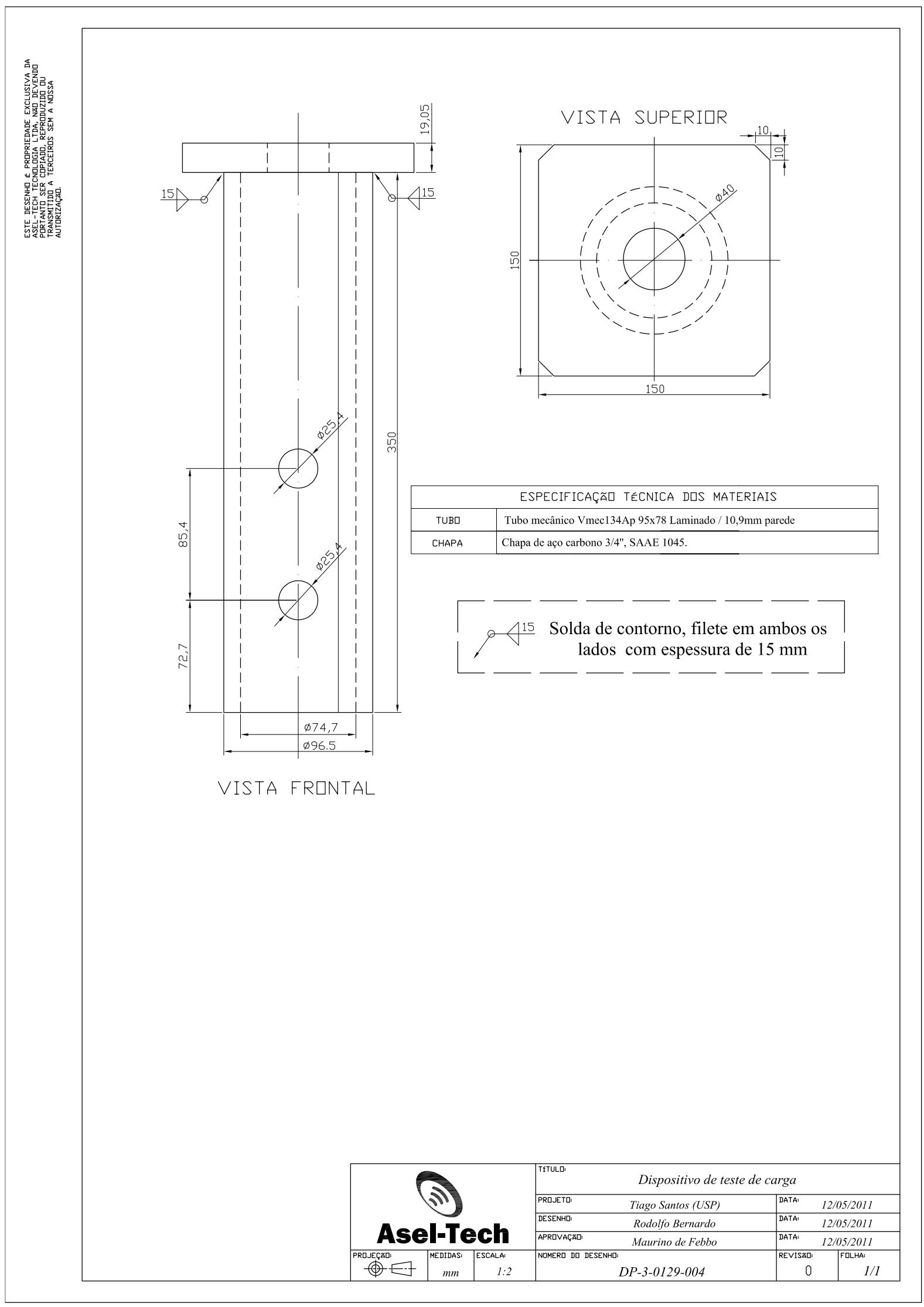




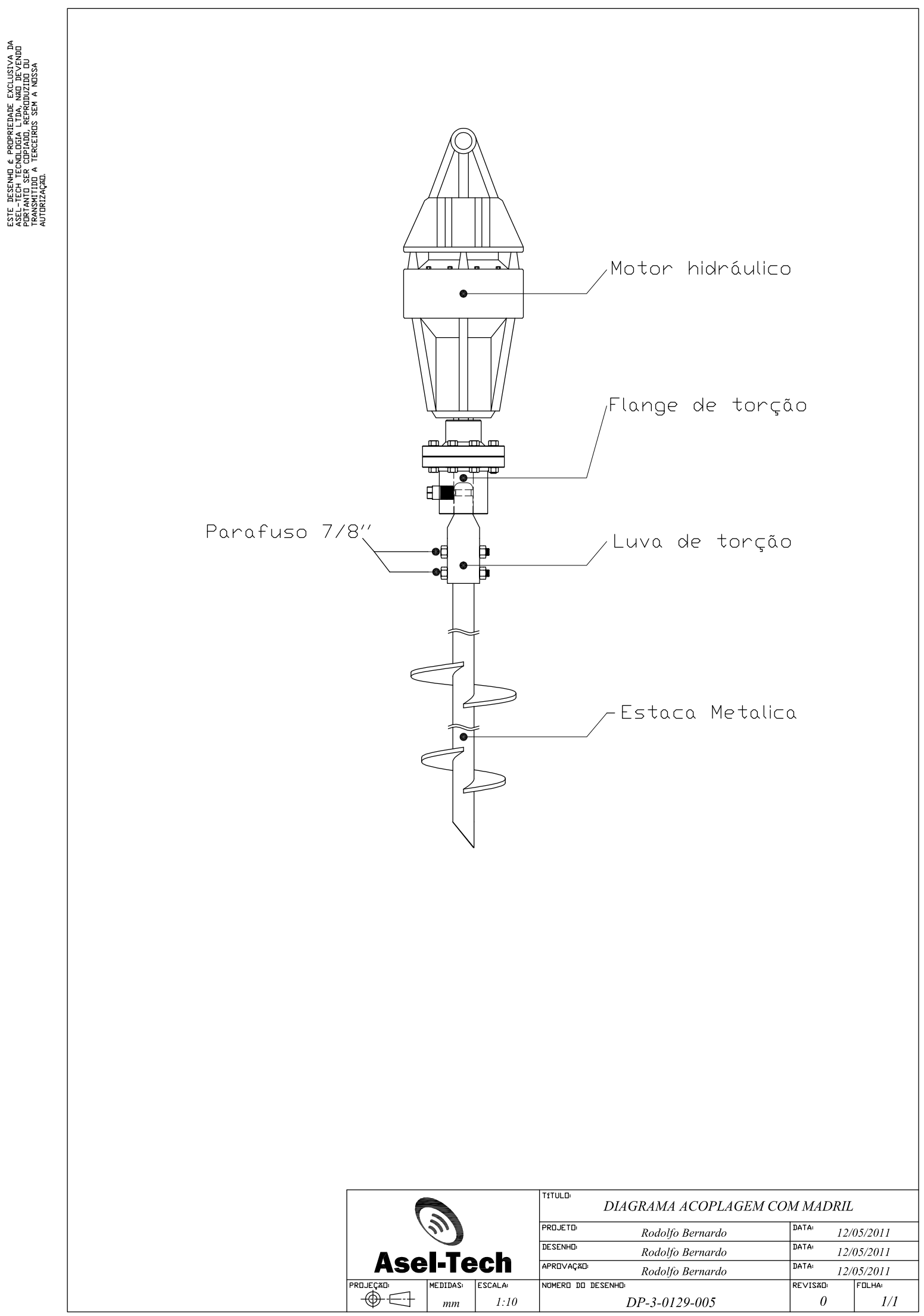

